\title{
Paducah Site Annual Report \\ For 1995
}

Project Coordinator

V. W. Jones

Technical Coordinators

V. W. Jones

S. E. Knaus

Technical Editor

G. Belcher

January 1997

Prepared for

the U.S. Department of Energy

under contract No. DE-AC05-84OR21400

by

Lockheed Martin Energy Systems, Inc. Environmental Management Division 761 Veterans Avenue

Kevil, Kentucky 42053 


\section{DISClaIMER}

Portions of this document may be illegible in electronic image products. Images are produced from the best available original document. 


\section{DISCLAIMER}

This report was prepared as an account of work sponsored by an agency of the United States Government. Neither the United States Government nor any agency thereof, nor any of their employees, make any warranty, express or implied, or assumes any legal liability or responsibility for the accuracy, completeness, or usefulness of any information, apparatus, product, or process disclosed, or represents that its use would not infringe privately owned rights. Reference herein to any specific commercial product, process, or service by trade name, trademark, manufacturer, or otherwise does not necessarily constitute or imply its endorsement, recommendation, or favoring by the United States Government or any agency thereof. The views and opinions of authors expressed herein do not necessarily state or reflect those of the United States Government or any agency thereof. 


\section{Contents}

Figures vii

Tables ix

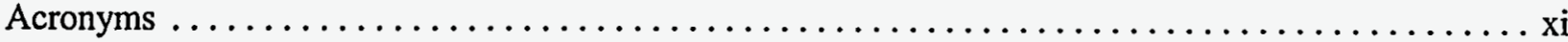

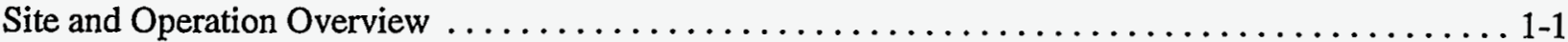

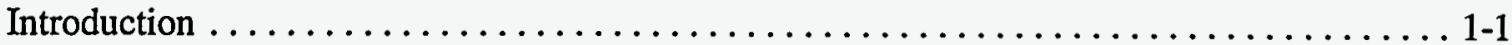

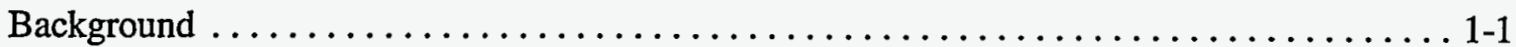

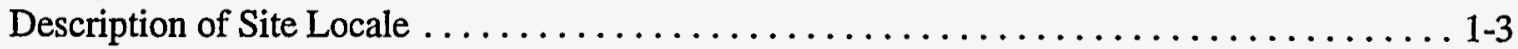

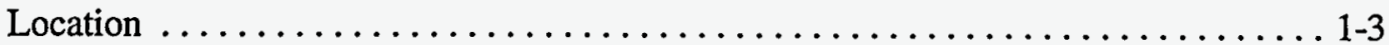

Climate ...................................... 1-3

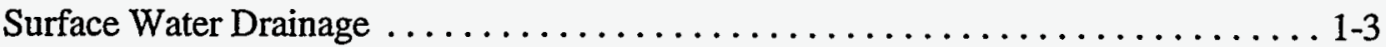

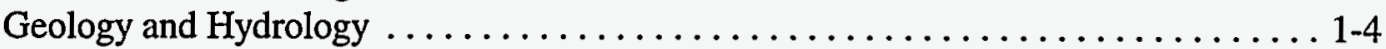

Ecological Resources . . . . . . . . . . . . . . . . . . . . . . . . . . . . . . .

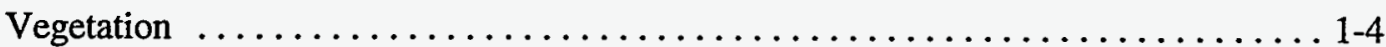

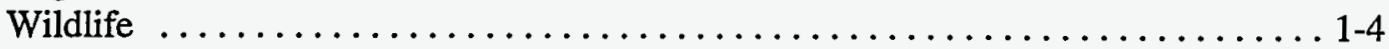

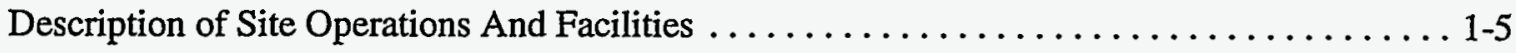

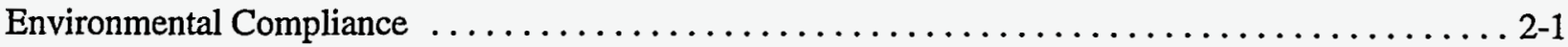

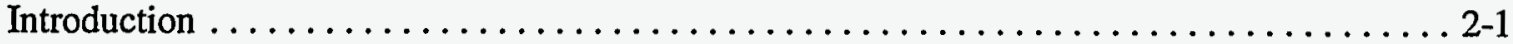

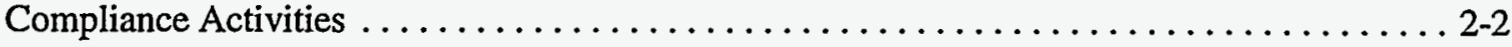

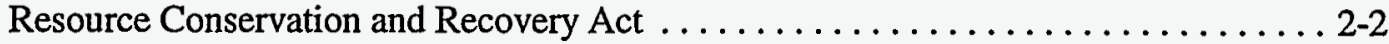

Land Disposal Restrictions .............................. 2-3

Solid Waste Management Compliance ....................... 2-4

Comprehensive Environmental Response, Compensation, and Liability Act $\ldots \ldots \ldots$ 2-4

Federal Facilities Compliance Act . . . . . . . . . . . . . . . . . . 2-7

Toxicity Characteristic Leaching Procedure FFCA $\ldots \ldots \ldots \ldots \ldots \ldots \ldots . . \ldots \ldots$

Underground Storage Tanks . . . . . . . . . . . . . . . . . . . . . 2-9

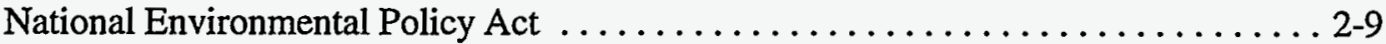

Other Environmental Acts, Regulations, and Statutes ................ 2-11

Clean Water Act . . . . . . . . . . . . . . . . . . . . . . . . . . 2-12

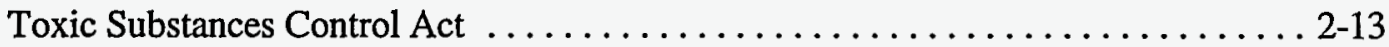

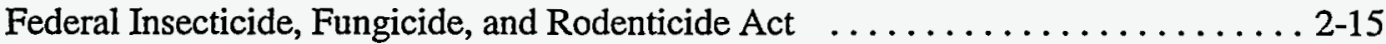

Emergency Planning and Community Right-To-Know Act . . . . . . . . . . . 2-15

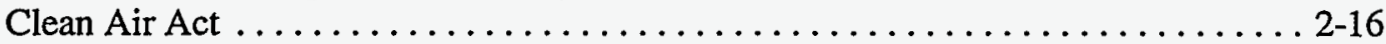

Kentucky/DOE Agreement in Principle . . . . . . . . . . . . . . . . . . . . 2-19

DOE Order Compliance ................................ 2-20

Assessments ........................................ 21

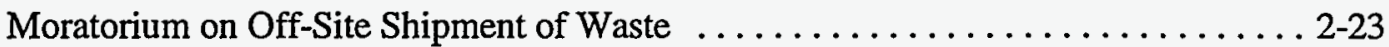




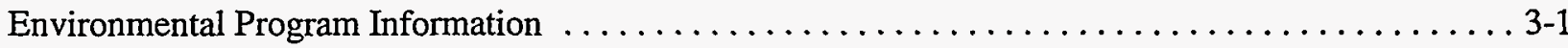

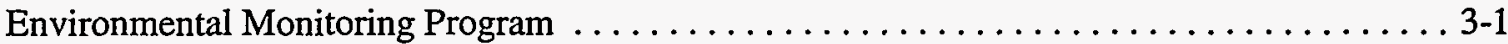

Environmental Restoration Program . . . . . . . . . . . . . . . . . . . .

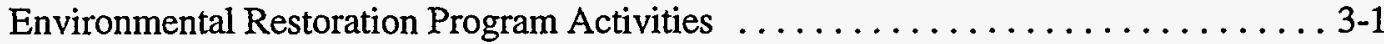

Waste Management Program . . . . . . . . . . . . . . . . . . . . . . . . . . 3-4

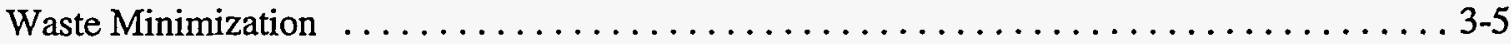

Vortec Vitrification Technological Demonstration . ....................... 3-6

Depleted Uranium Hexafluoride Cylinder Program $\ldots \ldots \ldots \ldots \ldots \ldots \ldots \ldots \ldots \ldots \ldots . . \ldots \ldots$

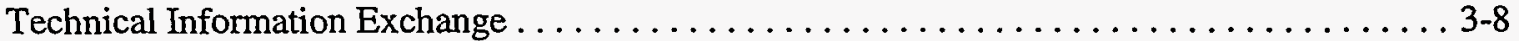

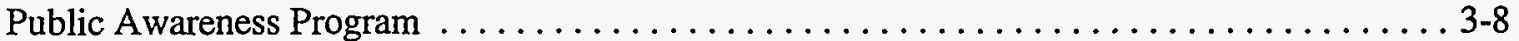

Information Bulletins, Fact Sheets, and Public Briefings .............. 3-8

Community/Educational Outreach . . . . . . . . . . . . . . . . . . 3-9

Earth Day .......................................... 3

Site Specific Advisory Board . . . . . . . . . . . . . . . . . . . . . . . . . .

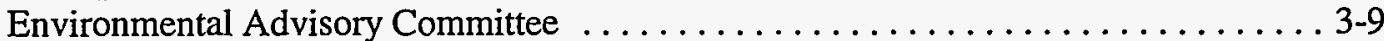

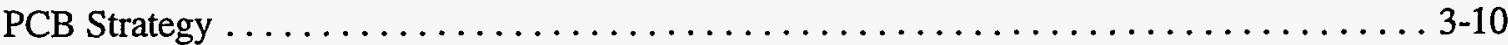

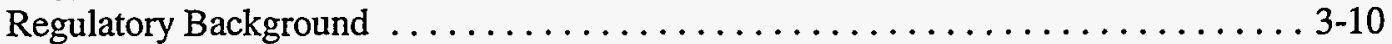

Summary of Regulatory Reporting and Associated Correspondence . . . . . . . . 3-10

Activities in 1995 . . . . . . . . . . . . . . . . . . . . . . . . . . . . 3-11

Results .................................

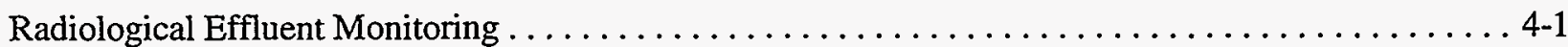

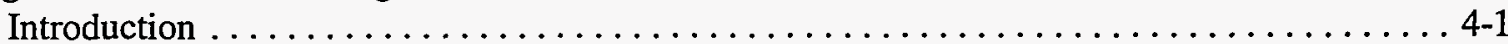

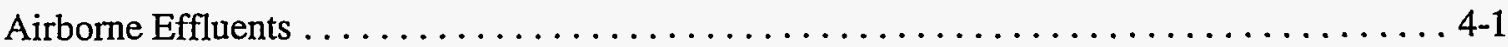

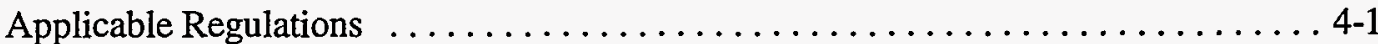

Airborne Effluent Results ............................ 4-3

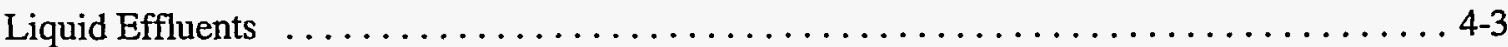

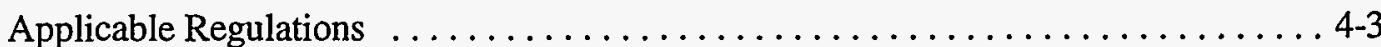

Liquid Effluent Monitoring Program . . . . . . . . . . . . . .

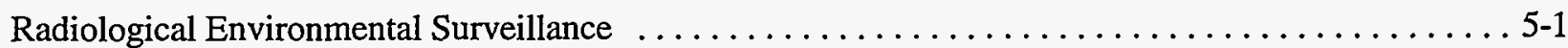

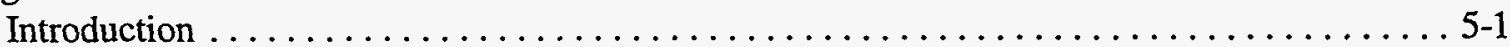

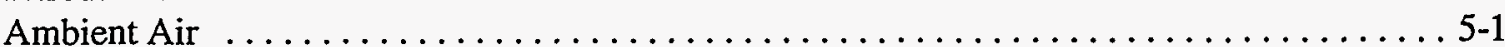

Meteorological Monitoring ........................ 5 .

Surface Water . . . . . . . . . . . . . . . . . . . . . . . . . . . .

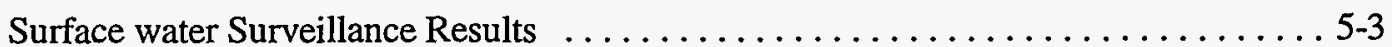

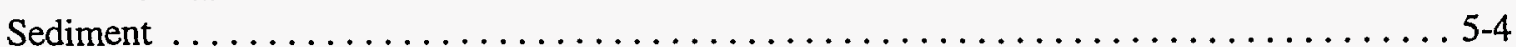

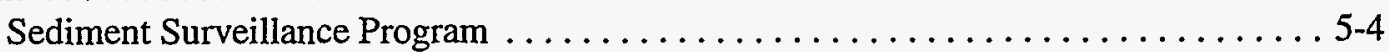

Sediment Surveillance Results . . . . . . . . . . . . . . . . . . . . . 5-5

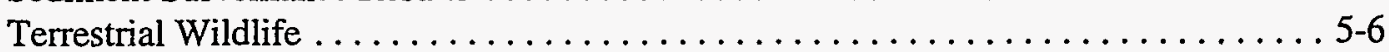

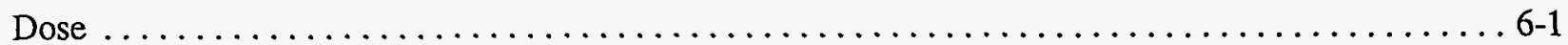

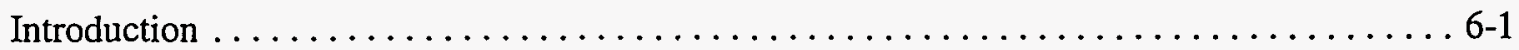

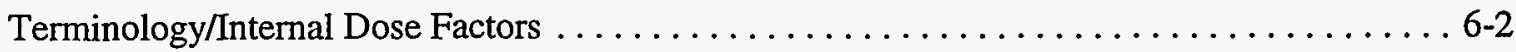

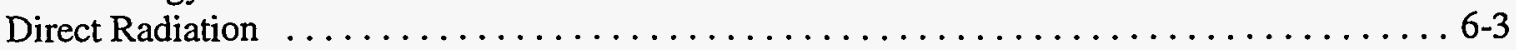

Contaminated Sediment in Little Bayou Creek $\ldots \ldots \ldots \ldots \ldots \ldots \ldots \ldots \ldots \ldots \ldots \ldots .6 \ldots \ldots$ 


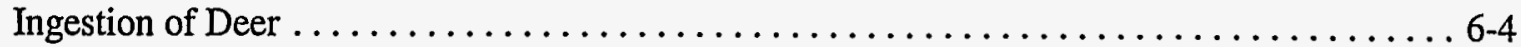

Airborne Radionuclides . . . . . . . . . . . . . . . . . . . . . . . . .

Conclusions ................................. $6-7$

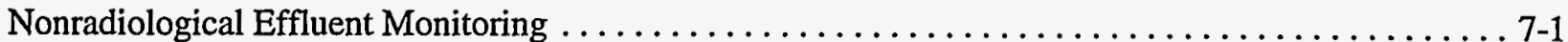

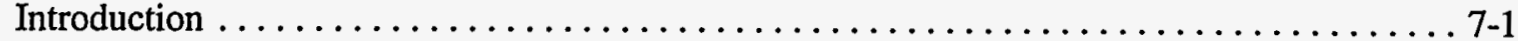

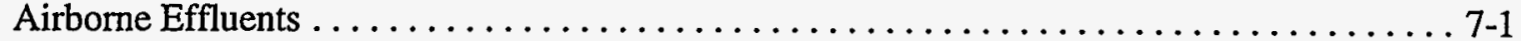

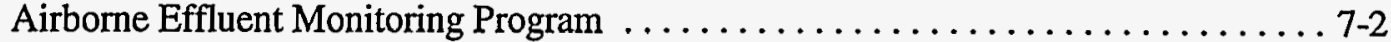

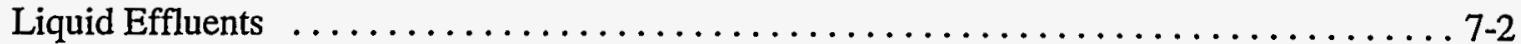

Liquid Effluent Applicable Regulations . . . . . . . . . . . . . . . . . 7-2

Liquid Effluent Monitoring Program ........................ $7-2$

Liquid Effluent Monitoring Results .................... $7-3$

Nonradiological Environmental Surveillance $\ldots \ldots \ldots \ldots \ldots \ldots \ldots \ldots \ldots \ldots \ldots \ldots \ldots . . .1$

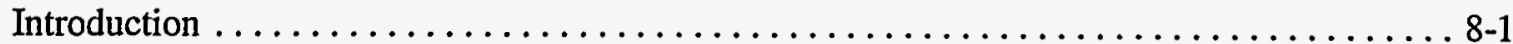

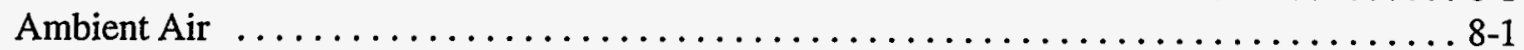

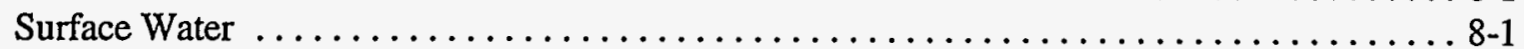

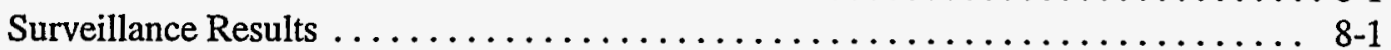

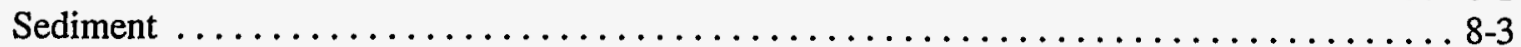

Sediment Surveillance Program $\ldots \ldots \ldots \ldots \ldots \ldots \ldots \ldots \ldots \ldots \ldots . \ldots \ldots . \ldots \ldots$

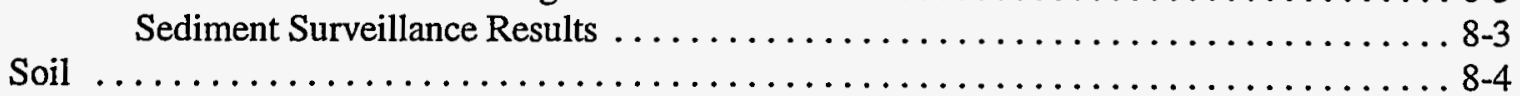

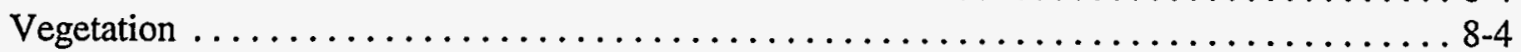

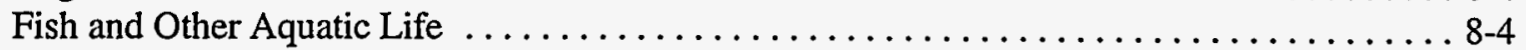

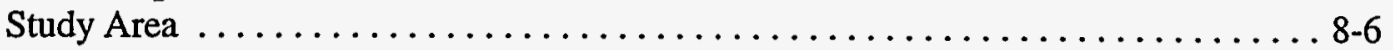

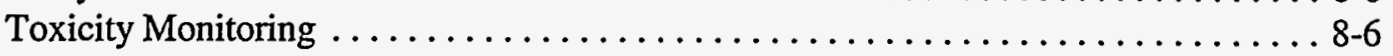

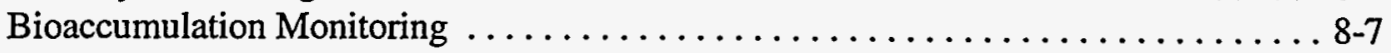

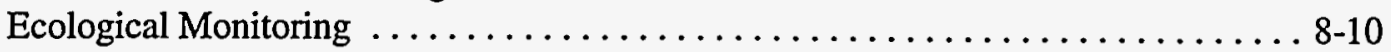

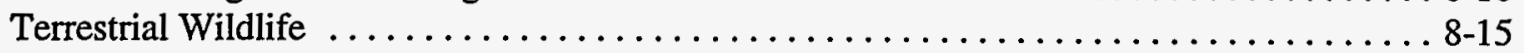

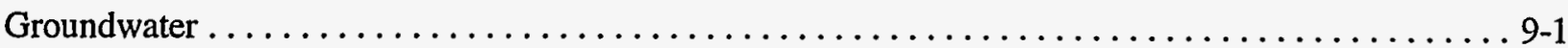

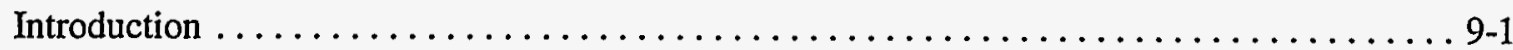

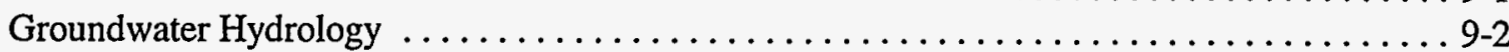

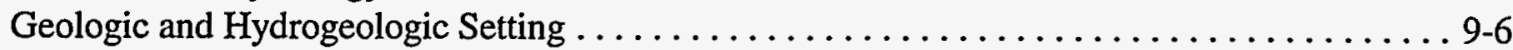

Uses of Groundwater in the Vicinity . . . . . . . . . . . . . . . .

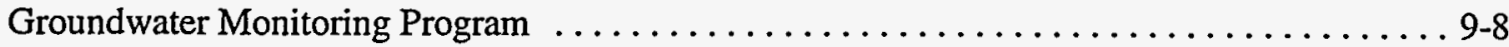

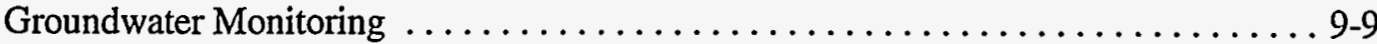

Underground Storage Tank Monitoring . .................... 9-9

RCRA Interim Status and Permit Monitoring Programs $\ldots \ldots \ldots \ldots \ldots \ldots . . . . .69$

State Solid Waste Disposal Regulations ........................ 9-9

CERCLA/ACO Monitoring (Off-Site Wells) . . . . . . . . . . . . . . 9-10

Environmental Surveillance Monitoring $\ldots \ldots \ldots \ldots \ldots \ldots \ldots \ldots \ldots . \ldots . \ldots \ldots$

Environmental Restoration Activities ........................... 9-11

Groundwater Integrator Unit $\ldots \ldots \ldots \ldots \ldots \ldots \ldots \ldots \ldots \ldots \ldots . \ldots \ldots \ldots \ldots .11$

Interim Action Record of Decision for the Northwest Plume ............ 9-12 
Interim Action Record of Decision for the Northeast Plume $\ldots \ldots \ldots \ldots \ldots \ldots 9-12$

Lasagna $^{\circledR}$ Demonstration ............................. $9-12$

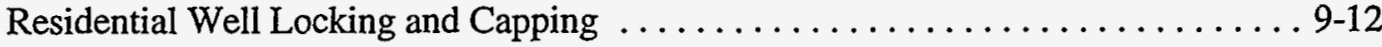

Site Evaluation for Outfall 010, 011, and 012 Areas $\ldots \ldots \ldots \ldots \ldots \ldots \ldots . \ldots .13$

Applicable Monitoring Standards . . . . . . . . . . . . . . . . . . . 9-13

Groundwater Monitoring Results $\ldots \ldots \ldots \ldots \ldots \ldots \ldots \ldots \ldots \ldots \ldots \ldots \ldots .13$

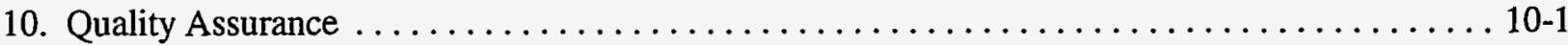

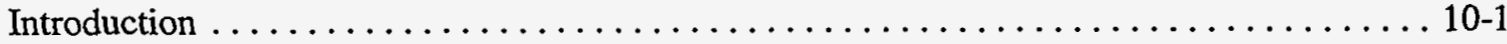

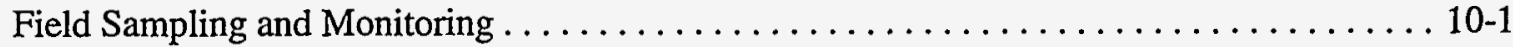

Basic Concepts and Practices ............................ 10-1

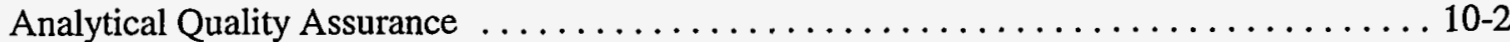

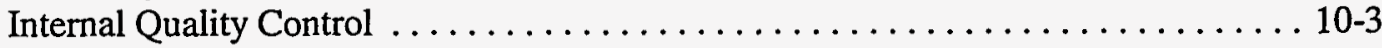

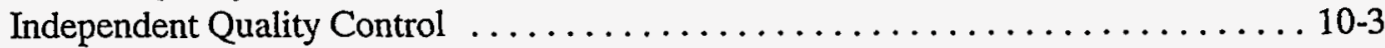

EPA Discharge Monitoring Report Quality Assurance Program . . . . . . . . . . . 10-3

Proficiency Environmental Testing Program . . . . . . . . . . . . . . . . 10-3

Proficiency Analytical Testing Program . . . . . . . . . . . . . . . . . . 10 10

DOE Environmental Measurements Laboratory Quality Assessment Program . . . . . 10 10-4

EPA Intercomparison Radionuclide Control Program . . . . . . . . . . . . . . 10-4

Mixed Analyte Performance Evaluation Program . . . . . . . . . . . . . . . . 10 10

Real World Soil and Wastewater Program . . . . . . . . . . . . . . . . 10-4

Water Supply Performance Evaluation Study and Water Pollution Performance

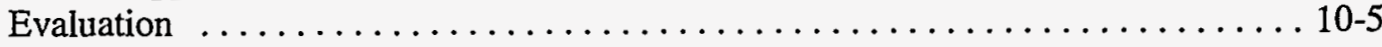

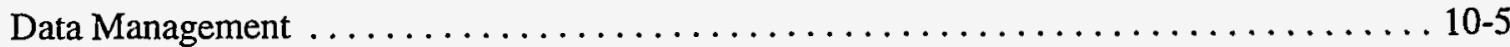

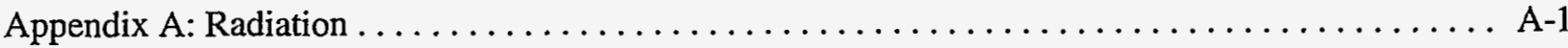

Appendix B: Radionuclide and Chemical

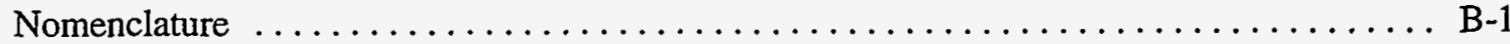

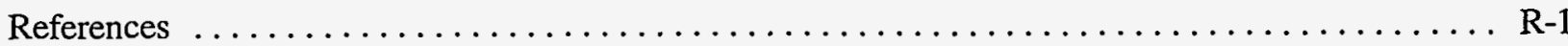

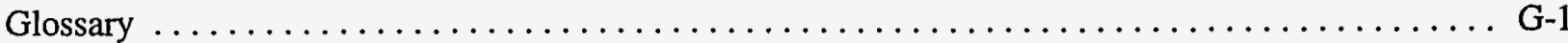

\section{Data Volume}

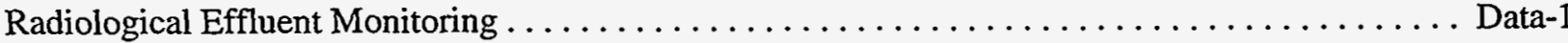

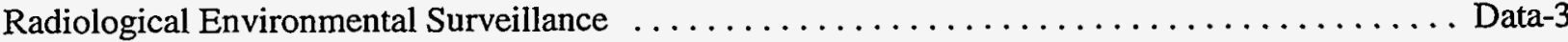

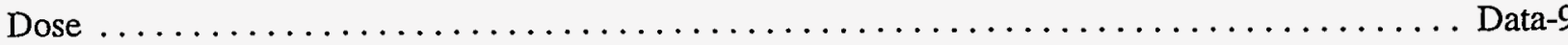

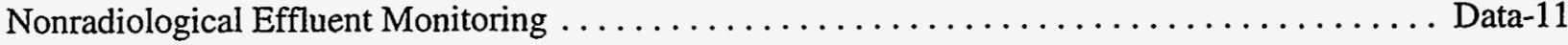

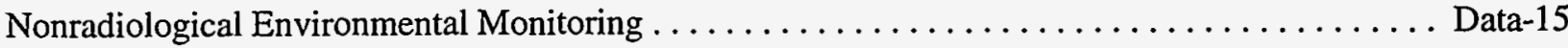




\section{Figures}

Figure $\quad$ Page

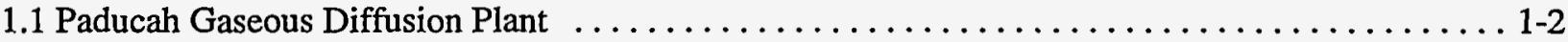

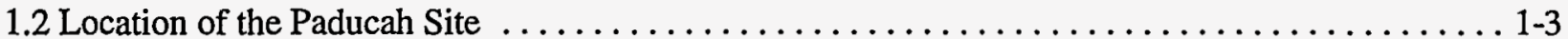

1.3 Representative wildlife that may be found at the Paducah Site $\ldots \ldots \ldots \ldots \ldots \ldots \ldots \ldots \ldots$

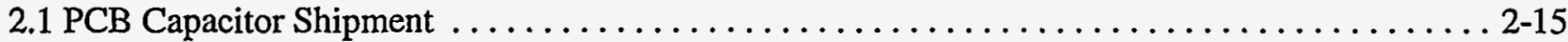

2.2 Nickel Ingot Asbestos Abatement Project handling activities $\ldots \ldots \ldots \ldots \ldots \ldots \ldots \ldots \ldots \ldots \ldots \ldots$

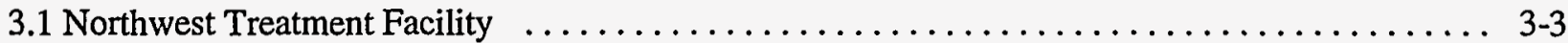

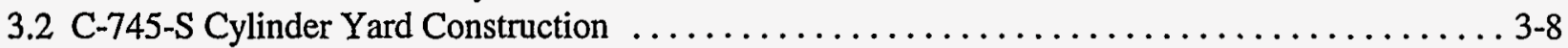

3.31995 Earth Day . . . . . . . . . . . . . . . . . . . . . . . . . . . . . . . . . . . 3-9

4.1 KPDES outfall locations at the Paducah Site ........................ 4-3

4.2 Uranium concentrations discharge to surface water, $1991-1995 \ldots \ldots \ldots \ldots \ldots \ldots \ldots \ldots$. . . . .

4.3 Technetium concentrations discharged to surface water, $1991-1995 \ldots \ldots \ldots \ldots \ldots \ldots \ldots .4 .45$

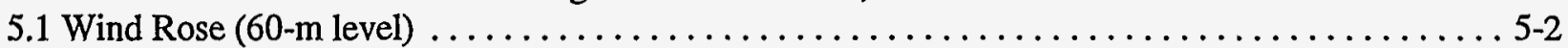

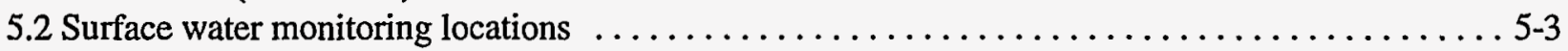

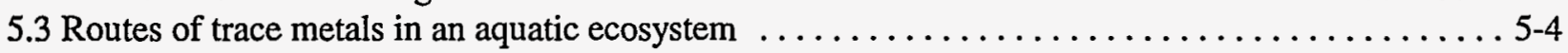

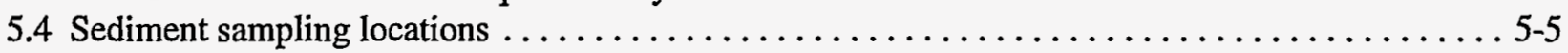

6.1 Possible pathways between radioactive material released to the atmosphere and individuals $\ldots \ldots 6-1$

6.2 Possible pathways between radioactive materials released to surface water and individuals . . . . 6-1

6.3 Potential radiological dose from the Paducah Site, 1991 thru $1995 \ldots \ldots \ldots \ldots \ldots \ldots \ldots \ldots$. . . . . . . .

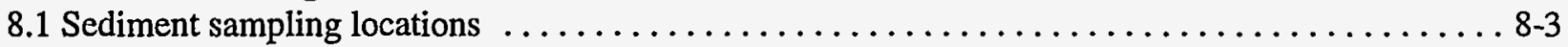

8.2 Biological Monitoring Sampling locations $\ldots \ldots \ldots \ldots \ldots \ldots \ldots \ldots \ldots \ldots \ldots \ldots \ldots$

8.3 Summary of $\mathrm{pH}$ and alkalinity at Big Bayou Creek, Little Bayou Creek, and Massac Creek sites

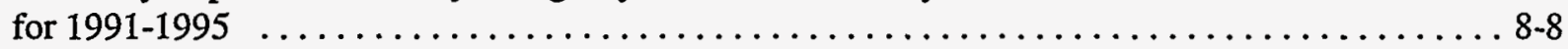

8.4 Summary of hardness and conductivity at Big Bayou Creek, Little Bayou Creek, and

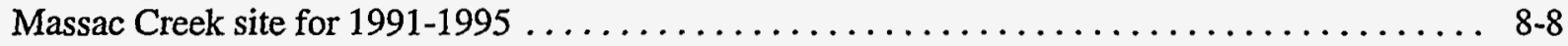

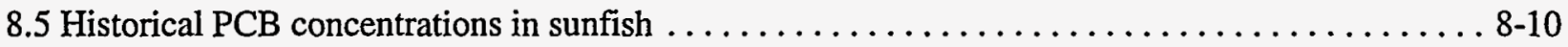

8.6 Collection of fish in Little Bayou Creek $\ldots \ldots \ldots \ldots \ldots \ldots \ldots \ldots \ldots \ldots \ldots \ldots \ldots \ldots$

8.7 Number of species, biomass, and density at Big Bayou sites $\ldots \ldots \ldots \ldots \ldots \ldots \ldots \ldots \ldots$. 11

8.8 Number of species, biomass, and density at Little Bayou Sites $\ldots \ldots \ldots \ldots \ldots \ldots \ldots \ldots \ldots$.11

8.9 Number of organisms and sensitive taxa in riffle communities $\ldots \ldots \ldots \ldots \ldots \ldots \ldots \ldots$. 13

8.10 Mean percent abundance of selected benthic macroinvertebrate taxa in Big Bayou Creek, Little

Bayou Creek, and Massac Creek . . . . . . . . . . . . . . . . . .

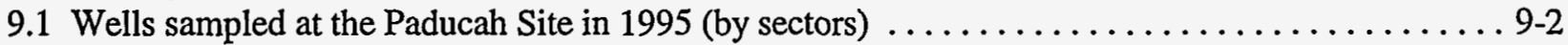

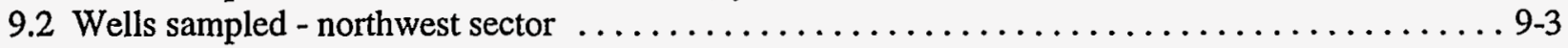

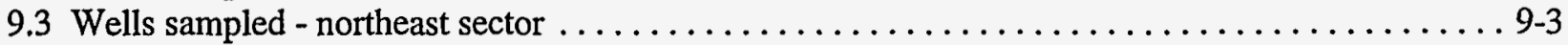

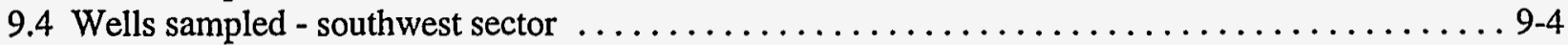

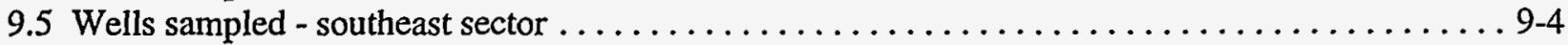

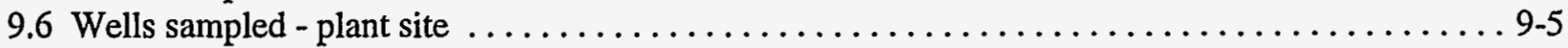

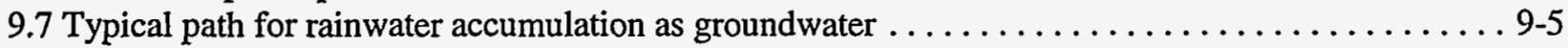

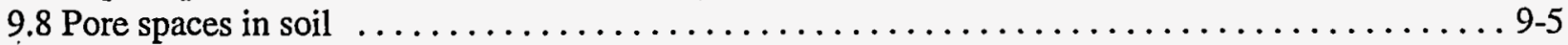

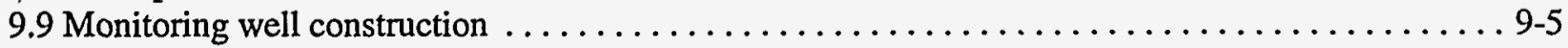

9.10 North-south section showing regional stratigraphic relationships $\ldots \ldots \ldots \ldots \ldots \ldots \ldots \ldots$.

9.11 Off-site extension of groundwater plumes $\ldots \ldots \ldots \ldots \ldots \ldots \ldots \ldots \ldots \ldots \ldots \ldots \ldots \ldots \ldots \ldots \ldots$ 


\section{Paducah Site}

9.12 Installation of the Lasagna ${ }^{\otimes}$ Demonstration $\ldots \ldots \ldots \ldots \ldots \ldots \ldots \ldots \ldots \ldots \ldots \ldots \ldots \ldots \ldots$

10.1 Summary analytical laboratory's performance evaluation by independent quality control programs

$10-5$ 


\section{Tables}

Table

Page

2.1 Environmental Permit Summary . . . . . . . . . .

2.2 Status of large, high-voltage PCB capacitors at Paducah in $1995 \ldots \ldots \ldots \ldots \ldots \ldots \ldots .24$

2.3 Summary of PCBs and PCB items in service at Paducah at the end of $1995 \ldots \ldots \ldots \ldots \ldots 2-15$

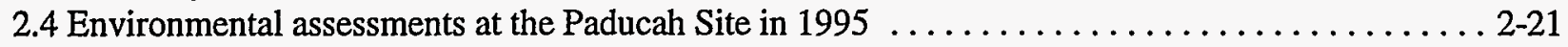

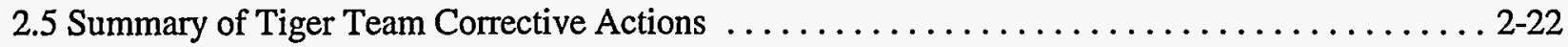

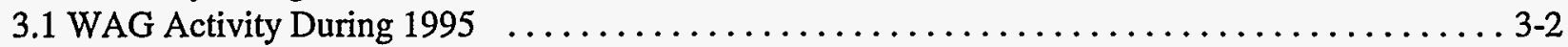

4.1 Northwest Treatment Facility ${ }^{99} \mathrm{Tc}$ air emissions for $1995 \ldots \ldots \ldots \ldots \ldots \ldots \ldots \ldots \ldots \ldots \ldots \ldots \ldots \ldots .2$

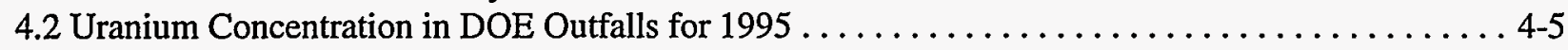

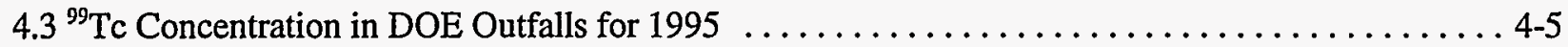

5.1 Sampling parameters and collection and analysis frequencies of surface water $\ldots \ldots \ldots \ldots \ldots 5$

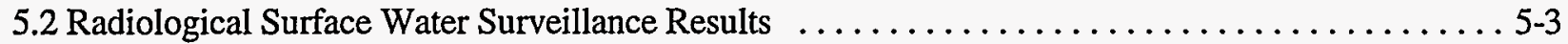

5.3 Sampling parameters and collection and analysis frequencies of sediment $\ldots \ldots \ldots \ldots \ldots \ldots 5$

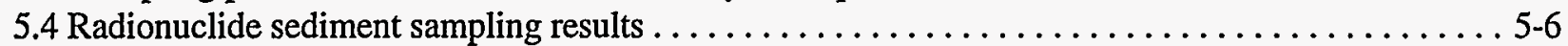

5.5 Five year Uranium concentrations in sediment . . . . . . . . . . . . . . . . . . .

5.6 Paducah Site annual deer harvest for 1995, analysis of liver tissue for radionuclides . . . . . . . . 5-7

5.7 Paducah Site annual deer harvest for 1995 - analysis of muscle tissue for radionuclides . . . . . . . 5-8

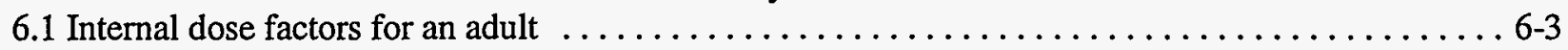

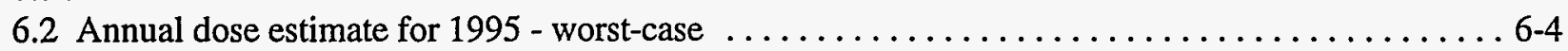

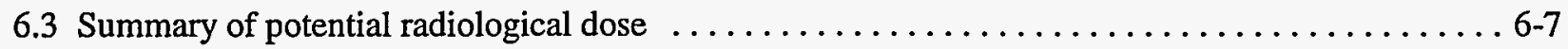

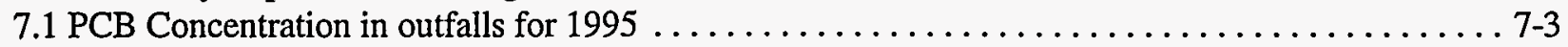

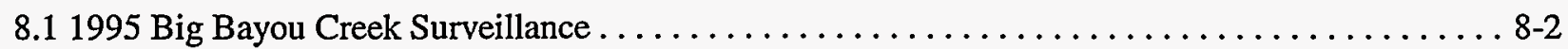

8.21995 Ohio River Surveillance $\ldots \ldots \ldots \ldots \ldots \ldots \ldots \ldots \ldots \ldots \ldots \ldots \ldots \ldots \ldots \ldots \ldots \ldots \ldots \ldots \ldots \ldots \ldots \ldots .2$

8.3 Sampling parameters and collection and analysis frequencies of sediment $\ldots \ldots \ldots \ldots \ldots \ldots$.

8.4 PCB results (in $\mu \mathrm{g} / \mathrm{g}$ ) for sediment samples from location $\mathrm{SS} 2,1991-1995 \ldots \ldots \ldots \ldots . . .48$

8.5 Nonradiological sediment sampling results for $1995 \ldots \ldots \ldots \ldots \ldots \ldots \ldots \ldots \ldots \ldots$

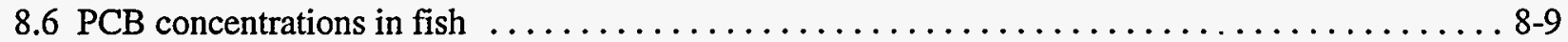

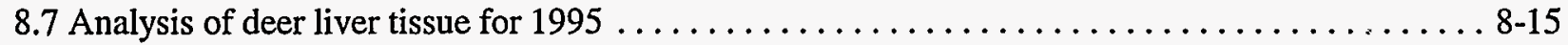

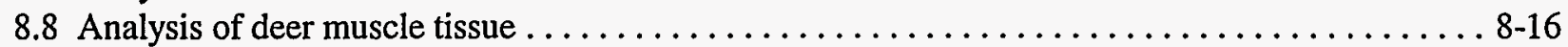

9.1 Applicable groundwater monitoring 1995 results $\ldots \ldots \ldots \ldots \ldots \ldots \ldots \ldots \ldots \ldots \ldots \ldots \ldots \ldots \ldots \ldots$

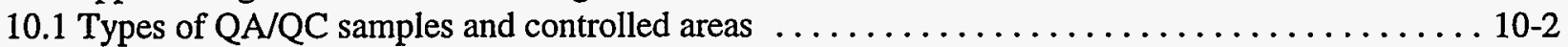




\section{Data Volume Tables}

1.11995 Annual Radiological Data Summary for Outfall K017 . . . . . . . . . . . . . Data-1

1.21995 Annual Radiological Data Summary for Outfall K018 . . . . . . . . . . . . . Data-1

2.11995 Annual Radiological Data Summary for Sampling Station SW1 . . . . . . . . . . Data-3

2.21995 Annual Radiological Data Summary for Sampling Station SW10 . . . . . . . . . Data-4

2.31995 Annual Radiological Data Summary for Sampling Station Sw29 . . . . . . . . . Data-4

2.41995 Annual Radiological Data Summary for Sampling Station SW3 . . . . . . . . . . Data-5

2.51995 Annual Radiological Data Summary for Sampling Station SW30 . . . . . . . . . . Data-5

2.61995 Annual Radiological Data Summary for Sampling Station SW4 . . . . . . . . . . Data-6

2.71995 Annual Radiological Data Summary for Sampling Station SW5 . . . . . . . . . . Data-6

2.81995 Annual Radiological Data Summary for Sampling Station SW64 . . . . . . . . . Data-7

3.1 Internal Dose Factors for an Adult . . . . . . . . . . . . . . . . . . . . . Data-9

4.1 Compliance Experience under Interim KPDES Limits for 1995 . . . . . . . . . . . Data-11

4.2 Compliance Experience under Interim KPDES Limits for 1995 . . . . . . . . . . . . Data-12

4.31995 Nonradiological Data Summary for Outfall $017 \ldots \ldots \ldots \ldots \ldots \ldots$. . . . . . . Data-12

4.41995 Nonradiological Data Summary for Outfall $018 \ldots \ldots \ldots \ldots \ldots \ldots \ldots$. . . . . Data-13

5.11995 Nonradiological Data Summary for Surface Water Location SW1 . . . . . . . Data-16

5.21995 Nonradiological Data Summary for Surface Water Location SW9 . . . . . . . . Data-17

5.31995 Nonradiological Data Summary for Surface Water Location SW3 . . . . . . . . Data-18

5.41995 Nonradiological Data Summary for Surface Water Location SW30 . . . . . . . Data-19

5.51995 Nonradiological Data Summary for Surface Water Location SW4 . . . . . . . . Data-19

5.61995 Nonradiological Data Summary for Surface Water Location SW5 . . . . . . . . Data-20

5.71995 Nonradiological Data Summary for Surface Water Location SW64 . . . . . . . Data-21

5.81995 Nonradiological Sediment Data Summary . . . . . . . . . . . . . . . . . . Data-22

5.9 Historical Nonradiological Sediment Sampling Results $(\mu \mathrm{g} / \mathrm{kg})$ for PCBs . . . . . . D Data-24 


\section{Acronyms and Abbreviations}

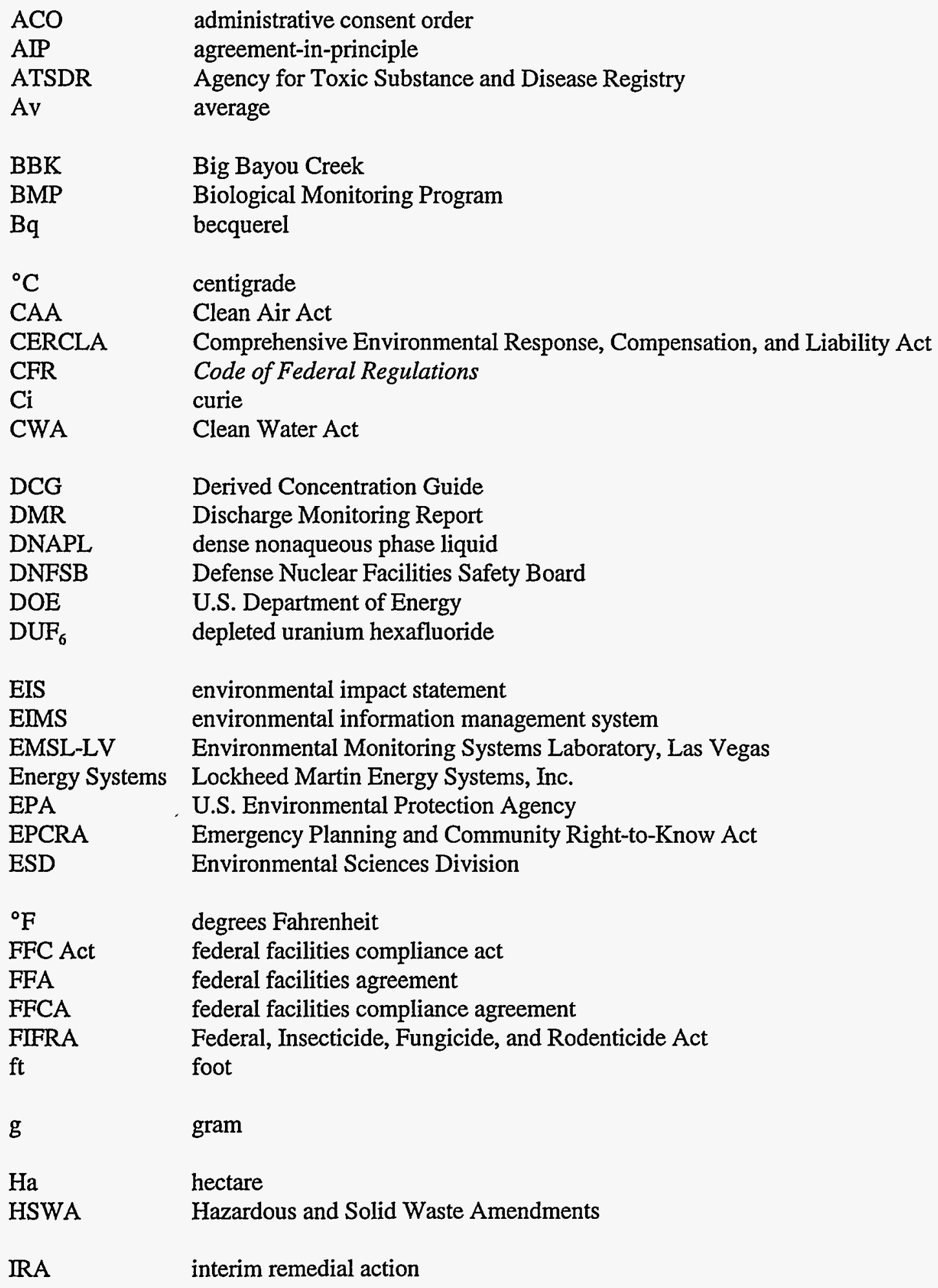




\begin{tabular}{|c|c|}
\hline $\mathrm{K}-25$ & Oak Ridge Gaseous Diffusion Plant \\
\hline KDAQ & Kentucky Division for Air Quality \\
\hline KDEP & Kentucky Department for Environmental Protection \\
\hline KDOW & Kentucky Division of Water \\
\hline KDWM & Kentucky Division of Waste Management \\
\hline $\mathrm{km}$ & kilometer \\
\hline KPDES & Kentucky Pollutant Discharge Elimination System \\
\hline $\mathrm{lb}$ & pound \\
\hline LMES & Lockheed Marietta Energy Systems, Inc. \\
\hline LUK & Little Bayou Creek \\
\hline $\mathrm{m}$ & meter \\
\hline $\mathrm{m}^{2}$ & square meter \\
\hline $\mathrm{m}^{3}$ & cubic meter \\
\hline MACT & Maximum Achievable Control Technology \\
\hline MAK & Massac Creek \\
\hline MAPEP & mixed analyte performance program \\
\hline $\operatorname{Max}$ & maximum \\
\hline$\mu \mathrm{Ci}$ & microcurie \\
\hline$\mu \mathrm{g}$ & microgram \\
\hline Min & minimum \\
\hline $\mathrm{ml}$ & milliliter \\
\hline $\mathrm{mm}$ & millimeter \\
\hline mrem & millirem \\
\hline MSDS & material safety data sheet \\
\hline $\mathrm{mSv}$ & millisievert \\
\hline MW & monitoring well \\
\hline NEPA & National Environmental Policy Act \\
\hline NESHAP & National Emission Standards for Hazardous Air Pollutants \\
\hline $\mathrm{No}_{x}$ & nitrogen oxides \\
\hline NOV & notice of violation \\
\hline NPDES & National Pollutant Discharge Elimination System \\
\hline NPL & National Priorities List \\
\hline OU & operable units \\
\hline PAT & Proficiency Analytical Testing \\
\hline PET & Proficiency Environmental Testing \\
\hline PCB & polychlorinated biphenyls \\
\hline $\mathrm{pCi}$ & picocurie \\
\hline PGDP & Paducah Gaseous Diffusion Plant \\
\hline $\mathrm{ppb}$ & parts per billion \\
\hline ppm & parts per million \\
\hline
\end{tabular}


QA

QC

RCRA

RFI

RGA

RI/FS

ROD

$\mathrm{SO}_{2}$

SPMD

SS

SSAB

SW

SWMU

${ }^{99} \mathrm{Tc}$

TCE

TSCA

$\mathrm{Tu}_{\mathrm{c}}$

UCRS

UE-FFCA

$\mathrm{UF}_{4}$

$\mathrm{UF}_{6}$

$\mathrm{UO}_{2}$

USEC

UST

Utility Services

WAG

WP

WS
Quality Assurance

Quality Control

Resource Conservation and Recovery Act

RCRA facility investigation

Regional Gravel Aquifer

remedial investigation/feasibility study

record of decision

sulfur dioxide

semi-permeable membrane devices

sediment sample location

Site Specific Advisory Board

surface water sample location

Solid Waste Management Unit

technetium-99

trichloroethylene

Toxic Substances Control Act

chronic toxicity unit

upper continental recharge system

Uranium Enrichment-Federal Facilities Compliance Agreement

uranium tetrafluoride

uranium hexafluoride

uranium dioxide

United States Enrichment Corporation

underground storage tank

Lockheed Martin Utility Services

1. waste area group

2. waste area grouping

Water Pollution Performance Evaluation Study

Water Supply Performance Evaluation Study 


\title{
1. Site and Operation Overview
}

\begin{abstract}
The Paducah Gaseous Diffusion Plant, located in McCracken County, Kentucky, has been producing enriched uranium since 1952. In July 1993, the U.S. Department of Energy (DOE) leased the production areas of the site to the United States Enrichment Corporation (USEC). A new subsidiary of Lockheed Martin Corporation, Lockheed Martin Utility Services, manages the leased facilities for USEC. DOE maintains responsibility for the environmental restoration, waste management, and enrichment facilities activities at the plant through its management contractor, Lockheed Martin Energy Systems. The purpose of this document is to summarize calendar year 1995 environmental monitoring activities for DOE activities at the Paducah Site. DOE requires all of its facilities to conduct and document such activities annually. This report does not include USEC environmental activities.
\end{abstract}

\section{Introduction}

The U.S. Department of Energy (DOE) requires that environmental monitoring be conducted and documented for all of its facilities under the purview of DOE Order 5400.1, General Environmental Protection Program. The purpose of this document is to summarize effluent monitoring and environmental surveillance results and compliance with environmental laws, regulations, and orders related to DOE activities at the Paducah Site. Environmental Programs at the Paducah Site are conducted under the auspices of the Lockheed Martin Energy Systems (Energy Systems) Environmental Management Program.

Environmental monitoring consists of two major activities: effluent monitoring and environmental surveillance. Effluent monitoring is direct measurement or the collection and analysis of samples of liquid and gaseous discharges to the environment. Environmental surveillance is direct measurement or the collection and analysis of samples of air, water, soil, foodstuff, biota, and other media. Environmental monitoring is performed to characterize and quantify contaminants, assess radiation exposures of members of the public, demonstrate compliance with applicable standards and permit requirements, and detect and assess the effects (if any) on the local environment. Multiple samples are collected throughout the year and are analyzed for radioactivity, chemical content, and various physical attributes.

The overall goal for environmental management is to protect the environment, Paducah Site's neighbors, and to maintain full compliance with all current environmental regulations. The current environmental strategy is to identify any deficiencies and develop a system to resolve them. The long-range goal of environmental management is to minimize the source of pollutants, reduce/eliminate the generation of waste, and minimize hazardous waste by substitution of materials.

\section{Background}

Before World War II, the area now occupied by the Paducah Gaseous Diffusion Plant (PGDP) was used for agricultural purposes. Numerous small farms produced various grain crops and provided pasture for livestock. Early in the war, a 6526-ha (16,126-acre) tract was assembled for construction of the Kentucky Ordnance Works, which was subsequently operated by the Atlas Powder Company until the end of the war, when it was turned over to the Federal Farm Mortgage Corporation and then to the General Services Administration. 
In 1950, the Department of Defense and DOE's predecessor, the Atomic Energy Commission, began efforts to expand fissionable material production capacity. As part of this effort, the National Security Resources Board was instructed to designate power areas within a strategically safe area of the United States. Eight government-owned sites were initially selected as candidate areas, one of which was the Kentucky Ordnance Works site. In October 1950, as a result of joint recommendations from the Department of Defense, Department of State, and the Atomic Energy Commission, President Truman directed the Atomic Energy Commission to further expand production of atomic weapons. One of the principal facets of this expansion program was the provision for a new gaseous diffusion plant. On October 18, 1950, the Atomic Energy Commission approved the Paducah Site for uranium enrichment operations and formally requested the Department of the Army to transfer the site from the General Services Administration to the Atomic Energy Commission.

Construction of PGDP was completed in 1954, although production of enriched uranium began in 1952. The plant's mission, uranium enrichment, has continued unchanged, and the original facilities are still in operation, albeit with substantial upgrading and refurbishment. Of the 3062 ha (7566 acres) acquired by the Atomic Energy Commission, 551 ha (1361 acres) were subsequently transferred to the Tennessee Valley Authority (Shawnee Steam Plant site) and 1125 ha (2781 acres) were conveyed to the Commonwealth of Kentucky for use in wildlife conservation and for recreational purposes (West Kentucky Wildlife Management Area). Thus, DOE's current holdings are 1386 ha (3423 acres), see Figure 1.1.

In October 1992, Congressional passage of the National Energy Policy Act established the United States Enrichment Corporation (USEC). Effective July 1, 1993, DOE leased the plant production operations facilities to USEC. Lockheed Martin Corporation created a new subsidiary, Lockheed Martin Utility Services (Utility Services), to manage the leased facilities for USEC under the prior management contract. Under the terms of the lease, USEC has assumed responsibility for

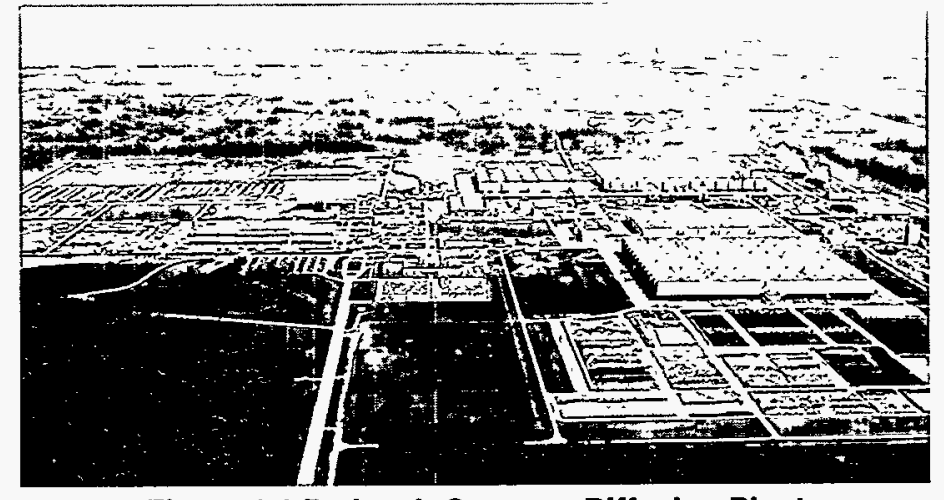

Figure 1.1 Paducah Gaseous Diffusion Plant compliance activities directly associated with uranium enrichment operations. DOE has retained responsibility for the site Environmental Restoration Program; the Depleted Uranium Hexafluoride Cylinder Program; the majority of the Waste Management Program, including waste inventories predating July 1, 1993; wastes generated by current DOE activities; wastes containing "legacy" constituents, such as asbestos, polychlorinated biphenyls, and transuranics; and Kentucky Pollutant Discharge Elimination System compliance at outfalls not leased to USEC. DOE has also retained manager and co-operator status of facilities not leased to USEC. DOE and USEC have negotiated the lease of specific plant site facilities, written memoranda of agreement to define their respective roles and responsibilities under the lease, and developed organizations and budgets to support their respective functions. 


\section{Description of Site Locale}

\section{Location}

The Paducah Site is located in a generally rural area of McCracken County, Kentucky. The plant is about 16 kilometers $(\mathrm{km})$ (10 miles) west of Paducah, Kentucky, and $4.8 \mathrm{~km}$ ( 3 miles) south of the Ohio River, see Figure 1.2. About 304 hectare (ha) ( 750 acres) are contained within the security fence where the cascade buildings (containing the uranium enrichment process equipment) and support facilities are located. An uninhabited buffer zone is provided by an extensive wildlife management area consisting of 850 ha ( 2100 acres) either deeded or leased to the Commonwealth of Kentucky. An office building in Kevil, which is located in Ballard County, is leased for several Energy Systems organizations. The Kevil facility is about 6 miles from the plant. The population within an $80-\mathrm{km}(50-$ mile) radius of the plant is about 300,500 , of which about 39,500 are located within a $16-\mathrm{km}(10-$ mile) radius.

\section{Climate}

The Paducah Site is located in the humid continental zone where summers are warm [July averages $26^{\circ} \mathrm{C}$ $\left(79^{\circ} \mathrm{F}\right)$ ] and winters are moderately cold [January
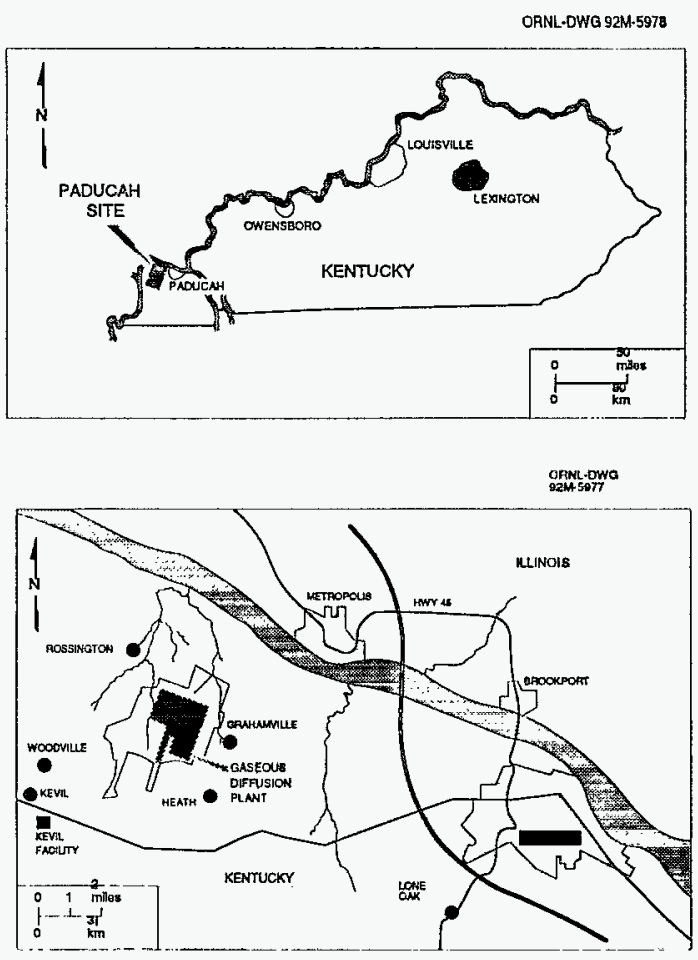

Figure 1.2 Location of the Paducah Site averages $\left.1.7^{\circ} \mathrm{C}\left(35^{\circ} \mathrm{F}\right)\right]$. Yearly precipitation averages about 120 centimeters (47 inches). The prevailing wind is from the south-southwest at approximately $16 \mathrm{~km}$ (10 miles) per hour.

\section{Surface Water Drainage}

The Paducah Site is situated in the western part of the Ohio River basin. The confluence of the Ohio River with the Tennessee River is about $24 \mathrm{~km}$ (15 miles) upstream of the site, and the confluence of the Ohio River with the Mississippi River is about $90 \mathrm{~km}$ (55 miles) downstream. The plant is located on a local drainage divide; surface flow is east-northeast toward Little Bayou Creek and west-northwest toward Big Bayou Creek. Big Bayou Creek is a perennial stream that flows toward the Ohio River along a 14.5-km (9-mile) course. Little Bayou Creek is an intermittent stream that flows north toward the Ohio River along a $10.5-\mathrm{km}$ (6.5-mile) course. The two creeks converge $4.8 \mathrm{~km}$ ( 3 miles) north of the plant before emptying into the Ohio River. 


\section{Geology and Hydrology}

Soils of the area are predominantly silt loams that are poorly drained, acidic, and have little organic content. The regional gravel aquifer is the uppermost aquifer underlying most of the Paducah Site and the contiguous area north. This groundwater flow system is developed primarily in Pleistocene sands and gravels of the lower member of the continental deposits, occurring between 13 and 33 meters $(\mathrm{m})(43$ and $100 \mathrm{ft}$ ) beneath the plant. The upper member of the continental deposits is predominantly composed of silt and clay with interbedded sand and gravel lenses. A layer of loess 3 to $10 \mathrm{~m}$ (10 to $30 \mathrm{ft}$ ) thick overlies the continental deposits at the surface. The continental deposits rest on terraces cut by the ancestral Tennessee and Tennessee-Ohio rivers. Within the regional gravel aquifer, flow is directed north, discharging into the Ohio River.

\section{Ecological Resources}

\section{Vegetation}

Much of the Paducah Site has been highly disturbed. Vegetation communities on the reservation are indicative of old field succession (i.e., grassy fields, field scrub-shrub, and upland mixed hardwoods).

The open grassland areas, managed by West Kentucky Wildlife Management Area personnel, are periodically mowed or burned to maintain early successional vegetation, which is dominated by members of the composite family and various grasses. Management practices on the Wildlife Management Area encourage reestablishment of once common native grasses such as eastern gama grass and Indian grass. Other species commonly cultivated for wildlife forage are corn, millet, milo, and soybean (CH2M Hill 1991a).

Field scrub-shrub communities consist of sun-tolerant wooded species such as persimmon, maples, black locust, sumac, scattered oaks, and mixed hardwood species (CH2M Hill 1991a). The undergrowth may vary depending on the location of the woodlands. Wooded areas near maintained grasslands may have an undergrowth dominated by grasses; other communities may contain a thick undergrowth of shrubs, including sumac, pokeweed, honeysuckle, blackberry, and grape.

Upland mixed hardwoods contain a variety of upland and transitional species. Dominant species include oaks, shagbark and shellbark hickory, and sugarberry (CH2M Hill 1991a). Undergrowth may vary from open, with limited vegetation for more mature stands of trees, to dense undergrowth similar to that described for a scrub-shrub community.

\section{Wildlife}

Wildlife species indigenous to hardwood forests and open grassland communities occur in the vicinity of the Paducah Site. Grassy fields are frequented by rabbits, mice, songbirds, and a variety of other small mammals and birds. Redwing blackbirds, killdeer, cardinals, mourning doves, bobwhite quail, meadowlarks, warblers, sparrows, and red-tailed hawks have been observed in such areas. Shrub-scrub communities support a variety of wildlife, Figure 1.3, including opossums, voles, moles, raccoons, gray squirrels, killdeer, bluejays, redwing blackbirds, bluebirds, cardinals, mourning doves, shrike, warblers, 
turkeys, and meadowlarks. Deer, squirrels, raccoons, turkeys, songbirds, and great horned owls are found within the mature woodlands of the DOE reservation (CH2M Hill 1991a). The Ohio River serves as a major flyway for migratory birds (SAIC 1992), which along with other transient animals, are occasionally seen on the Paducah Site.
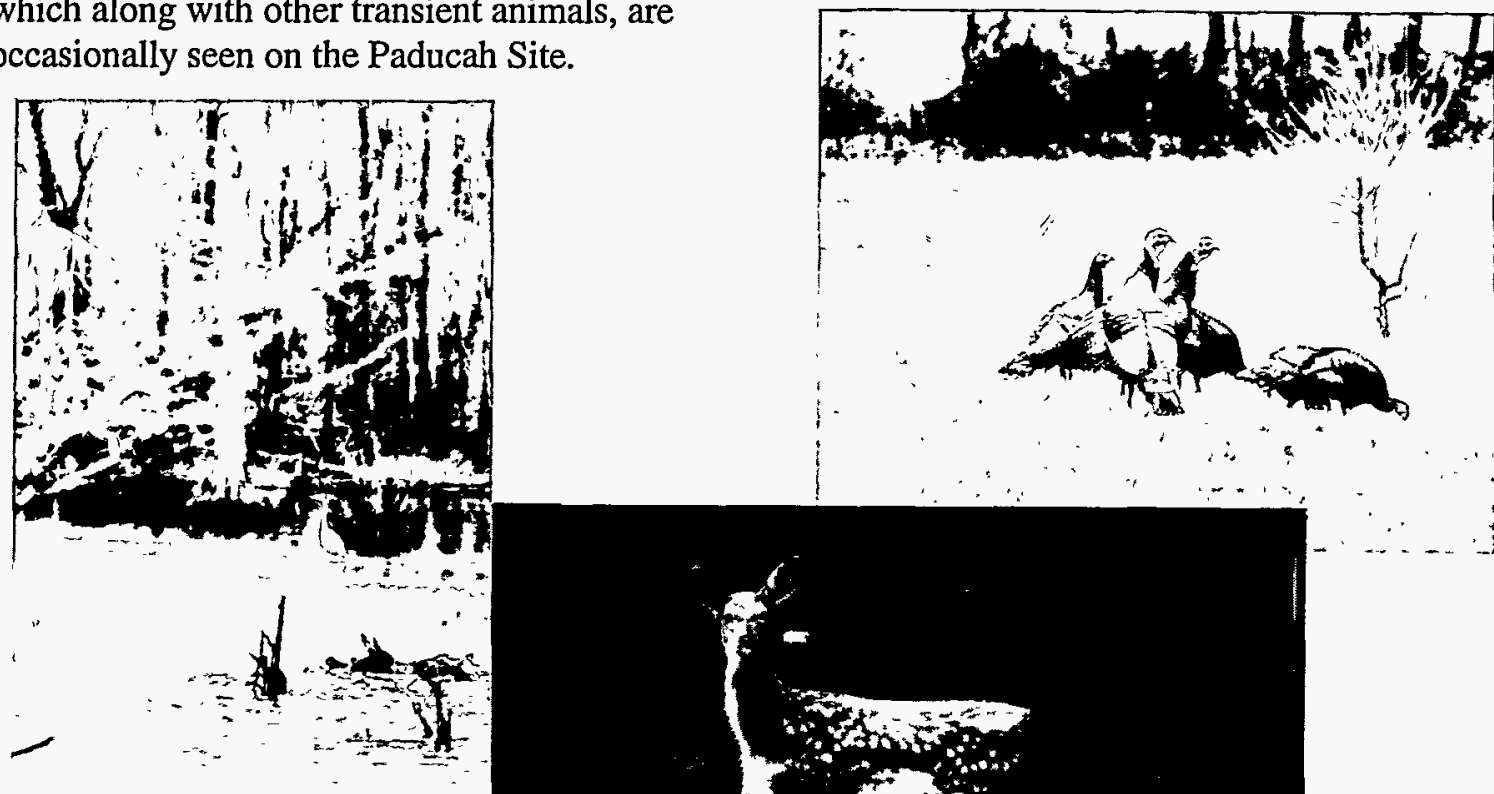
Kentucky Wildlife Management Area.

Amphibians and reptiles are common throughout the area surrounding the DOE reservation. Amphibians likely to inhabit the area include the American and Woodhouse's toad. Reptiles include the eastern box turtle and several species of snakes (SAIC 1992).

\section{Description of Site Operations And Facilities}

USEC, through its management contractor, Utility Services, operates production aspects of PGDP. The gaseous diffusion enrichment process uses the uranium hexafluoride $\left(\mathrm{UF}_{6}\right)$ form of uranium, which is a white, crystalline solid at ambient conditions and a gas at process conditions. The enrichment method increases uranium-235 $\left({ }^{235} \mathrm{U}\right)$ concentrations by physical processes; the $\mathrm{UF}_{6}$ gas is not altered chemically.

The gaseous diffusion process employs a series of compressors and converters to enrich the ${ }^{235} \mathrm{U}$ isotope of the process gas. The fundamental building block of the process consists of a compressor and a converter and is known as a stage. Stages are grouped together in series to form cells. The cells are then 
interconnected to provide what is known as a cascade. The compressors, which are driven by electric motors, are used to circulate the process gas and maintain flow through the cascade. The converters contain porous tubes or barriers through which the process gas is diffused. In each converter, a portion of the process gas diffuses through the barrier and is fed to the next higher stage, with the undiffused gas recycled to the next lower stage. The diffused stream is slightly enriched with respect to ${ }^{235} \mathrm{U}$, while the undiffused stream is depleted of ${ }^{235} \mathrm{U}$ to the same degree. Each stage also contains a gas cooler to remove the heat of compression from the process gas and a control valve for process control. The output of PGDP is one of the feed streams to the Portsmouth Gaseous Diffusion Plant in Ohio.

DOE, through its operating contractor, Energy Systems, operates the Environmental Restoration, Waste Management, and Enrichment Facilities programs at the plant. The goal of the Environmental Restoration Program is to ensure that releases from past operations and waste management at Paducah Site are thoroughly investigated and that appropriate remedial action is taken for protection of human health and the environment. The goal of the Waste Management Program is to characterize and dispose of the legacy waste stored on-site in compliance with various Federal Facilities Compliance Agreements (FFCAs). The goal of the Enrichment Facilities Program is to maintain safe, compliant storage of depleted uranium hexafluoride $\left(\mathrm{DUF}_{6}\right.$ ) pending final disposition of the material as outlined in the Programmatic Environmental Impact Statement; to manage facilities and grounds not leased to USEC; in addition to a variety of other projects related to DOE's ownership of the site. 


\title{
2. Environmental Compliance
}

\author{
Abstract \\ The policy of the Department of Energy and Lockheed Martin Energy Systems at the Paducah Site is to \\ conduct operations safely and minimize the impact of operations on the environment. Protection of the \\ public, environment, and employees is considered a responsibility of paramount importance.
}

\section{Introduction}

The Paducah Gaseous Diffusion Plant (PGDP) site is owned by the Department of Energy (DOE). Effective July 1, 1993, DOE leased the plant production operation facilities to the United States Enrichment Corporation (USEC). Lockheed Martin Corporation created a new subsidiary, Lockheed Martin Utility Services (Utility Services), to manage the leased facilities for USEC under the prior management contract. Under the terms of the lease, USEC has assumed responsibility for compliance activities directly associated with uranium enrichment operations. Lockheed Martin Energy Systems (Energy Systems) remains the management contractor for DOE responsibilities at the site. These responsibilities include the site Environmental Restoration Program; the Depleted Uranium Hexafluoride (DUF $_{6}$ ) Cylinder Program; the bulk of the Waste Management Program, including waste inventories predating July 1, 1993; wastes generated by current DOE activities; wastes containing "legacy" constituents, such as asbestos, polychlorinated biphenyls (PCBs), and transuranics; and Kentucky Pollutant Discharge Elimination System (KPDES) compliance at outfalls not leased to USEC. DOE has also retained manager and co-operator status of Resource Conservation and Recovery Act (RCRA) storage facilities not leased to USEC. DOE and USEC have negotiated the lease of specific site facilities, prepared memorandums of agreement to define their respective roles and responsibilities under the lease, and developed organizations and budgets to support their respective functions.

Local, state, and federal agencies, including DOE, are responsible for enforcing environmental regulations at the Paducah Site. Principal among other regulating agencies are the U.S. Environmental Protection Agency (EPA) Region IV and the Kentucky Department for Environmental Protection (KDEP). These agencies issue permits, review compliance reports, participate in joint monitoring programs, inspect facilities and operations, and oversee compliance with applicable regulations.

The EPA develops, promulgates, and enforces environmental protection regulations and technology-based standards as directed by statutes passed by the U.S. Congress. In some instances, the EPA has delegated regulatory authority to the KDEP when the Kentucky program meets or exceeds EPA requirements. Where regulatory authority is not delegated, EPA Region IV is responsible for reviewing and evaluating compliance with EPA regulations as they pertain to the Paducah Site. Table 2.1 includes a summary of the Paducah Site environmental permits maintained by DOE.

\section{Environmental Compliance}


Table 2.1 Environmental Permit Summary

\begin{tabular}{|c|c|c|c|}
\hline Permit Type & Issuer & Expiration Date & Permit Number \\
\hline \multicolumn{4}{|c|}{ Water } \\
\hline KPDES & Kentucky Division of Water & Oct. 31,1997 & KY0004049 \\
\hline KPDES - Landfill & Kentucky Division of Water & Aug. 31,2000 & KY0100072 \\
\hline Stormwater Point Sources & Kentucky Division of Water & Sept. 30,1997 & KYR100000 \\
\hline \multicolumn{4}{|c|}{ Solid Waste } \\
\hline Residential Landfill (closed) & $\begin{array}{c}\text { Kentucky Division of Waste } \\
\text { Management }\end{array}$ & Nov. 1, 1998 & 073-00014 \\
\hline Inert Landfill (closed) & $\begin{array}{c}\text { Kentucky Division of Waste } \\
\text { Management }\end{array}$ & June 11, 1998 & 073-00015 \\
\hline $\begin{array}{l}\text { Solid Waste Contained Landfill } \\
\text { (permit to construct) }\end{array}$ & $\begin{array}{c}\text { Kentucky Division of Waste } \\
\text { Management }\end{array}$ & Feb. 28,2005 & 073-00045 \\
\hline \multicolumn{4}{|c|}{$R C R A$} \\
\hline $\begin{array}{l}\text { State Hazardous Waste Management } \\
\text { Permit }\end{array}$ & $\begin{array}{c}\text { Kentucky Division of Waste } \\
\text { Management }\end{array}$ & Aug. 19,2001 & KY890008982 \\
\hline Mod. $7(3 / 30 / 95)$ & “ & “ & “ \\
\hline Mod. $8(6 / 26 / 95)$ & “ & “ & " \\
\hline Mod. $9(8 / 30 / 95)$ & “ & “ & “ \\
\hline $\begin{array}{l}\text { EPA Hazardous and Solid Waste } \\
\text { Amendments Permit }\end{array}$ & EPA & Aug. 19, 2001 & KY890008982 \\
\hline Mod. $4(11 / 17 / 95)$ & “ & “ & “ \\
\hline
\end{tabular}

\section{Compliance Activities}

\section{Resource Conservation and Recovery Act}

RCRA establishes regulatory standards for the identification, treatment, storage, and disposal of hazardous waste. Waste generators must follow specific requirements outlined in RCRA regulations for handling hazardous wastes. Owners and operators of hazardous waste management facilities are required to obtain operating and closure permits for hazardous waste treatment, storage and disposal activities. Paducah generates both hazardous waste and mixed waste (i.e., hazardous waste mixed with radionuclides).

\section{Environmental Compliance}




\section{RCRA Permit}

RCRA Part A and Part B permit applications for storage and treatment of hazardous wastes have been submitted for the Paducah Site. Since the EPA has authorized the Commonwealth of Kentucky to exclusively administer the RCRA base program for treatment, storage, and disposal units but not the authorization to administer the 1984 Hazardous and Solid Waste Amendments (HSWA) provisions, a permit application was submitted to both the EPA and Kentucky Division of Waste Management (KDWM). On July 16, 1991, a ten-year hazardous waste management permit (No. KY8890008982) was issued by the KDWM and the Environmental Protection Agency for the Paducah Site. This permit, issued to DOE as owner and operator and Energy Systems as a co-operator, authorizes the treatment and storage of hazardous wastes in a number of treatment units, tanks, and container storage areas.

This permit consists of two individual permits, a hazardous waste permit administered by the Commonwealth of Kentucky and a HSWA permit administered by the EPA. The hazardous waste permit issued by the Commonwealth of Kentucky contains regulatory provisions for treatment, storage, and disposal activities authorized under the RCRA base program (pre-HSWA), as well as the HSWA provisions. The EPA HSWA permit addresses only the provisions of the HSWA, which include corrective actions for solid waste management units (SWMUs). Since in 1995 Kentucky had not received authorization to administer the HSWA provisions in lieu of EPA provisions, Paducah's permit has dual requirements for corrective actions under state and federal laws.

As part of the HSWA requirements, the RCRA permit's schedule of compliance requires DOE to develop and implement a RCRA facility investigation (RFI) work plan for SWMUs and areas of concern. DOE has submitted RFI work plans to the EPA and the KDWM in accordance with the time-frames specified in the schedule of compliance. These RFI work plans are described in further detail in the section regarding Comprehensive Environmental Response, Compensation, and Liability Act (CERCLA) activities.

\section{Modifications to the RCRA Permit}

Through December 1995, nine (9)permit modifications have been approved. Authorization for the new waste container storage area (C-752-A) was granted in March 1995. The Interim Remedial Action for the Northwest Treatment Facility was also incorporated into the permit in 1995.

\section{RCRA Notices of Violation}

The KDWM performed a compliance evaluation inspection in February and November of 1995 . No notices of violation (NOVs) were issued.

\section{Land Disposal Restrictions}

Mixed waste (RCRA and radioactive) is generated and stored at the Paducah Site. Such waste is subject to the land disposal restriction storage prohibition that permits storage only for accumulation of sufficient quantities to facilitate proper treatment, recycle, or disposal. Mixed waste is being stored at the Paducah Site because of a nationwide shortage of treatment and disposal facilities for this type of waste. Storage of

\section{Environmental Compliance}


waste for this purpose does not comply with land disposal restriction regulations. If not for the radioactive constituents, this waste would not pose a compliance problem for the site. Consequently, on June 30, 1992, DOE entered into a federal facilities compliance agreement (FFCA) with EPA Region IV to regulate the treatment and storage of land disposal restriction mixed waste at the Paducah Site.

\section{Solid Waste Management Compliance}

The Paducah Site disposes of a portion of its solid waste at a KDWM permitted on-site landfill. In 1995 the C-746-S Landfill stopped receiving waste and was certified closed. Construction of a new landfill, C-746-U, began in 1995, according to new state regulations. Upon closure of the C-746-S Landfill, DOE and Energy Systems office waste which is collected by Utility Services was sent to Liquid Waste Disposal at Calvert City, Kentucky along with waste from Utility Services.

\section{Comprehensive Environmental Response, Compensation, and Liability Act}

In July 1988, the Kentucky Radiation Control Branch, in conjunction with the Purchase District Health Department, sampled several residential groundwater wells north of the plant in response to concerns from a local citizen regarding the quality of water in a private well. Subsequent analyses of these samples revealed elevated gross beta levels, indicative of possible radionuclide contamination. On August 9, 1988, these results were reported to the Paducah Site, which responded by sampling several private groundwater wells around the site on August 10,1988. Upon analysis, some of the samples collected contained elevated levels of both trichloroethylene (TCE) and technetium- $99\left({ }^{99} \mathrm{Tc}\right)$. In response, DOE immediately instituted the following response actions:

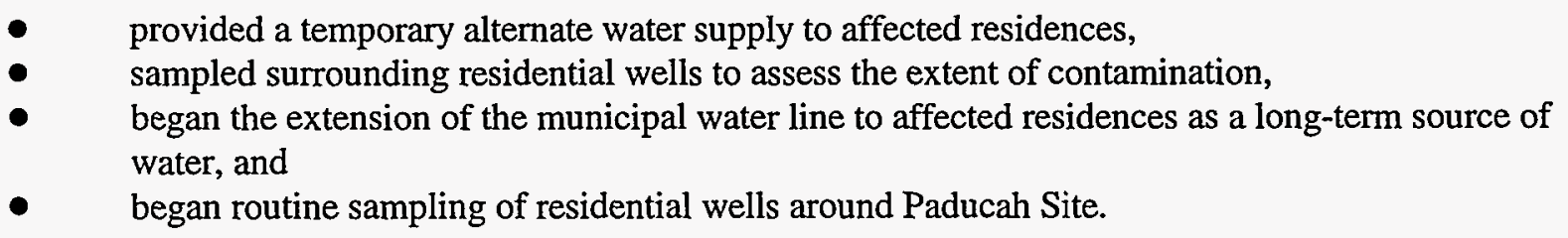

Following the initial response actions, in August 1988 DOE and the EPA entered into an administrative consent order $(A C O)$ under Sections 104 and 106 of the CERCLA. The major requirements of the ACO include monitoring of residential wells potentially affected by contamination, providing alternative drinking water supplies to residents with contaminated wells, and investigation of the nature and extent of off-site contamination. Pursuant to the ACO, DOE continued routine sampling of residential wells and initiated a two-phase site investigation to identify the nature and extent of off-site contamination at the Paducah Site. Phase I of the site investigation, from summer 1989 to March 1991, evaluated the extent of off-site contamination at the Paducah Site through extensive groundwater monitoring and surface water sampling. Results of the Phase I activities are reported in Results of the Site Investigation, Phase I (CH2M Hill 1991b). Phase II of the site investigation, from November 1990 to October 1991, focused on identification and characterization of on-site sources contributing to off-site contamination, determined the level of risk to human health and the environment from exposure to contaminated media and biota, and developed an initial list of remedial alternatives. Results are reported in Results of the Site Investigation, Phase II (CH2M Hill 1992a). The principal findings of the site investigation follow:

\section{Environmental Compliance}


- $\quad \mathrm{TCE}$ and ${ }^{99} \mathrm{Tc}$ were identified as the primary contaminants in off-site groundwater at the Paducah Site.

- A northwest and a northeast groundwater plume extending off site were delineated.

- $\quad$ PCBs and radionuclides were identified as the primary contaminants detected in surface water and sediment in outfalls, ditches, and creeks around the Paducah Site.

- Several on-site sources were identified as potential contributors to off-site contamination.

Risks to human health and the environment from exposure to contamination originating at the Paducah Site were reported in Results of the Public Health and Ecological Assessment, Phase II (CH2M Hill 1992b). This report used data collected during the site investigation to quantitatively assess risks to human health and to qualitatively assess risks to the environment. A range of preliminary alternatives that could be used to address the contamination was also developed as part of the ACO activities. This information presented in Summary of Alternatives for Remediation of Off-Site Contamination at the Paducah Gaseous Diffusion Plant, Paducah, Kentucky (Draft) (SAIC 1991a). Upon completion of the Phase II activities and in response to the risks identified in the public health and ecological assessment, the Paducah Site developed and implemented several interim remedial actions designed to prevent further off-site migration of contaminants and to reduce risks to human health and the environment. The actions targeted certain on-site sources and the off-site contamination associated with groundwater and surface water.

As part of the routine residential sampling that began when off-site contamination was discovered, DOE established a water policy. This policy was that in the event that contamination originating from the Paducah Site is detected above plant-action levels, which are established at the analytical laboratory detection limits of 25 picocuries per liter $\left(\mathrm{pCi} / \mathrm{L}\right.$ ) for ${ }^{99} \mathrm{Tc}$ and 1 part per billion (ppb) for TCE, a response will be initiated by the Paducah Site. Accordingly, residents are notified immediately; state and EPA officials are also notified. Alternative water supplies are provided through connection to the municipal water system, or in the event of a time lapse between discovery and the ability to complete connections, bottled water is made available. DOE pays the cost of installation of water systems and the monthly charges for water service to residents with contaminated wells.

DOE modified this water policy to include provisions to extend a municipal water line to the entire area potentially affected by groundwater contamination originating from the Paducah Site. All residents within the affected area, regardless of whether or not their wells are contaminated, were given the option to receive municipal water at $\mathrm{DOE}$ expense. Of the 83 eligible property owners: 73 signed agreements to accept the water provision and not to use or dig wells on their property. Any eligible resident who did not sign a license agreement before November 1, 1993 (with the exception of those with wells contaminated from the plant), and anyone who establishes residence after that date will not be provided municipal water at DOE expense.

Because of the extension of the municipal water line, the new water policy allows reduction in the number and frequency of residential wells sampled routinely. This modification will provide for a more cost-effective allocation of well-sampling resources and, through the strategic placement of additional monitoring wells, will allow more accurate data on location and movement of contaminated groundwater.

\section{Environmental Compliance}


The most significant interim action taken under the ACO, documented in Technical Memorandum for Interim Remedial Action of the Northwest Plume (DOE/OR/1031\&D2), was developed to evaluate groundwater extraction and treatment to reduce the spread of contamination from the source and high concentration areas of the Northwest Plume. The Proposed Plan for Interim Remedial Action of the Northwest Plume (DOE/OR/06-1127\&D2), which summarizes the interim alternatives, was approved by the EPA on April 15, 1993. The Record of Decision for Interim Remedial Action of the Northwest Plume (DOE/OR/06-1143\&D2)) was signed by DOE on July 15, 1993, and by the EPA on July 22, 1993. Construction of the interim action (the C-612 Northwest Treatment Facility) was completed and operational on August 28, 1995.

Other interim actions completed to date include the North-South Diversion Ditch, Institutional Controls for the surface water/ditches and scrapyards and the enhancement of the existing cap for Waste Area Group (WAG) 7, C-746-K Landfill. The North-South Diversion Ditch, which is being used to treat certain plant effluents and control the migration of contaminated sediment associated with the ditch, was completed and operational on October 18, 1995. The installation of fencing/posting for off-site contamination in surface water, outfalls and lagoons and the installation of sediment controls to mitigate surface water/sediment runoff from scrap yards has also been completed and is inspected on a monthly basis. The existing cap for the C-746-K Landfill was enhanced to reduce leachate migration from surface infiltration.

The interim remedial actions for the Northeast Plume and WAG 22 (SWMU2 -Burial Ground) are currently in the remedial design phase. The Record of Decision (ROD) for Interim Remedial Action (IRA) at the Northeast Plume (DOE/OR/06-1356\&D2) was signed by DOE on June 13,1995, and the EPA on June 1,1995 . The ROD calls for the hydraulic containment and treatment of high concentrations of offsite TCE contamination in the Northeast Plume. The Record of Decision (ROD) for Interim Remedial Action (IRA) at Solid Waste Management Units 2 and 3 of Waste Area Group 22 at the Paducah Gaseous Diffusion Plant (DOE/OR/06-1351\&D1) was signed by DOE on August 16,1995, and by EPA on August 22, 1995. The ROD for WAG 22 (SWMU 2 - Burial Ground) calls for the installation of an impermeable cap to reduce leachate migration from surface infiltration if data indicates the waste is not at depths that would be in direct contact with groundwater. The action also involves institutional controls and monitoring.

On May 31, 1994, the Paducah Site was placed on the EPA National Priorities List (NPL), a list of sites across the nation designated by EPA as a high priority for site remediation. The EPA uses the Hazard Ranking System to determine which sites should be included on the NPL. A site is eligible for the NPL if it ranks 28.5 on the system; the Paducah Site ranked 56.9. Being placed on the NPL means that DOE must follow the cleanup requirements of CERCLA. Section 120 of CERCLA requires federal facilities on the NPL to enter into a federal facilities agreement (FFA), also referred to as an interagency agreement, with the appropriate regulatory agencies. The FFA will serve as a comprehensive procedure for remediation of the Paducah Site and will integrate CERCLA remedial action requirements with RCRA corrective action requirements specified in the RCRA permits. Negotiations with the EPA and the KDEP to finalize the FFA began in June 1993. Once the FFA is finalized, the parties have agreed to terminate the CERCLA ACO because those activities can be continued under the FFA. Under the FFA, DOE is required to submit an annual site management plan to the EPA and KDEP. The plan will summarize the remediation work completed to date, outline remedial priorities, and present schedules for completing future work.

\section{Environmental Compliance}


In 1995, the Agency for Toxic Substances and Disease Registry (ATSDR) visited the Paducah Site to initiate a public health assessment. The DOE Site Office hosted the visit with support from Energy Systems for arrangements and briefings. ATSDR representatives made their initial site visit to Paducah in May 1994 for the purpose of assigning a ranking to the site for priority in scheduling the health assessment. A " $\mathrm{B}$ " ranking was assigned to Paducah, which is the second highest priority. The ranking was based on groundwater contamination, associated with the plant, that had affected several off-site wells. The ATSDR is aware of the actions the site has taken since 1988 to remove the risk of drinking and using this contaminated water.

The ATSDR, based in Atlanta, Georgia, is part of the U. S. Public Health Service. As required by CERCLA, the agency conducts public health assessments of hazardous waste sites listed or proposed for listing on the NPL. Since their initial site visit, representatives of the ATSDR have attended two Paducah Site public workshops and a planning meeting for a proposed Site Specific Advisory Board. ATSDR has also written residents near the PGDP to invite them to suggest community health concerns related to the plant.

\section{CERCLA Notices of Violation}

No CERCLA NOVs were received in 1995.

\section{CERCLA-Reportable Quantities}

There were no spills of a CERCLA reportable quantity at the Paducah Site in 1995.

\section{Federal Facilities Compliance Act}

The Federal Facilities Compliance (FFC) Act was enacted in October 1992. This act waived the immunity from fines and penalties that had existed for federal facilities for violations of hazardous waste management as defined by RCRA. As a result of the complex issues and problems associated with mixed chemical hazardous and radioactive waste (mixed waste) and the lack of treatment and disposal capacity, the FFC Act allowed a three-year extension for DOE facilities to prepare schedules and plans on how they would manage their mixed waste in compliance with applicable RCRA regulations. The three-year waiver can be extended if (1) a mixed waste treatment plan and compliance schedule are approved by the appropriate agency, (2) an implementing order with that agency is signed, and (3) adherence to the plan and implementing order are maintained by the facility.

To facilitate compliance with the FFC Act and address the myriad of complex issues involved, the Paducah Site, along with 48 other DOE sites, began a four-phase approach. The first phase consisted of gathering required information and submitting to the EPA and state agencies an inventory of mixed wastes (mixed waste inventory report), including information pertaining to characterization and waste generation volumes. In addition, annual updates to the report are to be submitted each year. The Paducah Site submitted the annual update to the state and to EPA Region IV in June 1995. The second phase involved the development of a conceptual site treatment plan. The plan included investigation of the existing treatment capacity for facility wastes and, where there was no existing capacity, procurement of

\section{Environmental Compliance}


information on potential treatment technologies or options that could be employed to meet operation requirements. The Paducah Site submitted the conceptual site treatment plan in October 1993. The third phase expanded on the information in the conceptual site treatment plan to identify treatment options that are preferred both environmentally and economically. The information gathered by the ongoing waste characterization program and the technology evaluation and development program outlined in the conceptual site treatment plan formed the basis for the draft site treatment plan, which was submitted to the regulators in August 1994. The fourth phase is to combine the preferred treatment options from the draft site treatment plan with regulator and stakeholder comments and the overall DOE complex picture to formulate a proposed site treatment plan. This proposed site treatment plan was submitted to the regulators on March 31, 1995, and provides details on how and where Paducah Site mixed waste is to be treated.

On October 4, 1995 KDWM issued an Unilateral Order and Site Treatment Plan for the Paducah Site. On November 3, 1995, the DOE appealed the Unilateral Order due to requirements of the Residual Management Contingency Plan and funding language in the Order. The appeal is pending. Meanwhile, the site has been complying.

\section{FFC Act NOVs}

The Paducah Site is in compliance with the FFC Act. No NOVs were received during 1995.

\section{Toxicity Characteristic Leaching Procedure FFCA}

The Paducah Site has generated a significant volume of waste materials that are stored on-site. A large quantity of this waste was generated, characterized, and placed in storage before September 25, 1990, when the toxicity characteristic regulations, Title 40, Code of Federal Regulations, Part 261.24 (40 CFR 261.24), became effective. The site had accumulated a significant volume of solid wastes that had not been characterized under the new toxicity characteristic regulations and that was not stored in RCRA-regulated units, DOE needed revised characterization of these wastes by the new protocol.

On March 26, 1992, EPA Region IV and DOE entered into a toxicity characteristic leaching procedure FFCA concerning the regulatory status of these wastes. The FFCA requires the Paducah Site to identify those solid wastes that were not being managed in RCRA-regulated units and that had not been characterized under the toxicity characteristic leaching procedure test method. Additionally, the FFCA requires the Paducah Site to provide a schedule for toxicity characteristic leaching procedure characterization of the identified waste.

In response to the FFCA, the Paducah Site submitted an implementation plan that established a general framework for compliance with the requirements of the FFCA. The implementation plan established priorities for the characterization program and the nature of the data to be collected to address the requirements of the FFCA. The primary characterization objectives were defined as the acquisition of sufficient data to safely handle the waste and provide for determination of its status under RCRA. Characterization of the waste with respect to PCB and radionuclide concentrations was established as the second objective. The final characterization objective was the collection of data related to treatment and/or disposal of the waste.

\section{Environmental Compliance}


A three-phase program for accomplishing the goals of the plan is under way. Phase I activities consist of data compilation and waste prioritization. Phase II involves identification of discrete waste streams and development of characterization plans. The final phase of the program includes the development of sampling and analysis plans, field sampling, and data reporting.

Phase I of the program has been completed. Phases II and III can now be carried out in succession on a waste stream basis. Approximately a dozen characterization plans are near or at completion. These characterization plans are being used to guide the development of the sampling and analysis plans for the discrete waste streams. As sampling and analysis plans are completed, field activities will begin.

\section{Toxicity Characteristic Leaching Procedure FFCA NOVs}

The Paducah Site is in compliance with the toxicity characteristic leaching procedure FFCA. No NOVs were received during 1995.

\section{Underground Storage Tanks}

Underground storage tanks (USTs) at the Paducah Site were used to store petroleum products, such as gasoline, diesel fuel, and heating oil. These tanks are regulated under Subtitle I and Subtitle C of RCRA.

The UST program includes 15 USTs, the status of which follows:

- USTs excluded from regulation (three) - One UST is excluded from regulation because its volume is less than 110 gal. Letter from KDWM on 11/30/95 stated intention to pursue no further action for this UST. Two additional USTs are part of a wastewater treatment system and are excluded.

- HSWA permit-deferred USTs (nine) - Three tanks in WAG 15 are to be sampled for potential closure in place under the state UST regulations. Four tanks within WAG 7 were submitted to the state as no further action. Two tanks within WAG 4 are being proposed as no further action. It is noted that the Paducah Site has been allowed to defer the investigation for these tanks to the HSWA permit until Environmental Restoration addresses the tanks through the Corrective Actions or CERCLA programs.

- Closed USTs (three) - One UST has been closed pursuant to RCRA, Subtitle C. RCRA closure was approved by the KDWM on June 20,1994. Two USTs have been removed and are being closed pursuant to UST Corrective Action Plan. Results of the investigation are being prepared for review by the KDWM.

\section{UST Program NOVs}

No UST NOVs were received in 1995.

\section{National Environmental Policy Act}

The National Environmental Policy Act (NEPA) provides a means to evaluate the potential environmental impact of proposed federal activities and to examine alternatives to those actions. Compliance with NEPA,

\section{Environmental Compliance}


as administered by NEPA Implementing Procedures (10 CFR 1021) and Council on Environmental Quality Regulations (40 CFR 1500-1508), ensures that consideration is given to environmental values and factors in federal planning and decision making. To strengthen its NEPA review and documentation process, DOE promulgated new NEPA regulations on May 26, 1992. These new regulations expanded the list of categorical exclusions available for use and refined the NEPA Implementing Procedures to more closely parallel Council on Environmental Quality Regulations.

NEPA reviews of environmental restoration activities were incorporated into the CERCLA review process. These actions are discussed in the environmental restoration sections of this report.

In 1995, the DOE Oak Ridge Operations Office determined that two actions at the Paducah Site were categorically excluded. In addition, 9 other proposed projects were approved internally by applying previously approved categorical exclusions. The Paducah DOE Site Office and the DOE Oak Ridge Operations Office NEPA compliance officer approve and monitor the internal applications of previously approved categorical exclusion determinations. The Paducah Site used five previously approved categorical exclusions for activities such as routine maintenance and small-scale modifications.

DOE was preparing two environmental assessments for the Paducah Site in 1995. Preparation continued on the Proposed Sale of Radioactively Contaminated Nickel Ingots Located at the Paducah Gaseous Diffusion Plant Paducah, Kentucky DOE/EA-0994. Preparation began on an environmental assessment for Refurbishment of Uranium Hexafluoride Cylinder Storage Yards C-745-K, L, M, N, and $P$ and Construction of a New Uranium Hexafluoride Cylinder Storage Yard (C-745-T) at the Paducah Gaseous Diffusion Plant, Paducah, Kentucky DOE/EA-1118.

No environmental impact statement (EIS) determinations or EISs were submitted or approved during 1995. Two nationwide programmatic EISs are being prepared by DOE. The Waste Management Programmatic Environmental Impact Statement DOE/EIS-0200 would develop a systematic, integrated approach to waste management at all DOE sites. The Depleted Uranium Hexafluoride Programmatic Environmental Impact Statement addresses the long-term management and use of depleted uranium hexafluoride currently stored in cylinders. The Paducah Site has assisted in the programmatic EISs by providing site specific information.

Increased emphasis is being placed on early identification of potential impacts from proposed projects on environmentally sensitive resources such as wetlands, floodplains, cultural resources, federally and state-listed species and habitats, and prime farmland. In conjunction with the NEPA process, all proposed projects are reviewed for compliance with the Endangered Species Act of 1973; the National Historic Preservation Act of 1966; 10 CFR 1022, "Compliance with Floodplain/Wetlands Environmental Review Requirements"; and the Farmland Protection Policy Act of 1981 (see also discussions under "Other Environmental Acts, Regulations, and Statutes"). Through an interagency agreement the U.S. Army Corps of Engineers was tasked with identifying wetlands, floodplains, federally and state-listed threatened and endangered species and their habitats, and cultural resources on approximately 4746 hectare (ha) (11,719 acres) surrounding the Paducah Site. Information from the final Corps of Engineers report, dated May 1994, has been incorporated into project planning to decrease the potential for impacts on environmentally sensitive resources.

\section{Environmental Compliance}




\section{Other Environmental Acts, Regulations, and Statutes}

\section{National Historic Preservation Act}

The National Historic Preservation Act of 1966 is the primary law governing federal agencies' responsibilities for identifying and protecting historic properties (cultural resources included in, or eligible for inclusion in, the National Register of Historic Places). Although there are currently no historic properties at the Paducah Site in the National Register of Historic Places, each proposed project is assessed to determine if there are any historic properties present and whether they may be affected. In making these determinations, DOE consults with the State Historic Preservation Officer as required by Section 106 of National Historic Preservation Act.

In 1995, no activities were conducted which adversely affected historic properties.

\section{Endangered Species Act}

The Endangered Species Act of 1973, as amended, provides for the designation and protection of endangered and threatened animals and plants. The act also serves to protect ecosystems on which such species depend. At the Paducah Site, field surveys are performed to identify threatened and endangered species and their habitats, and mitigating measures are designed as needed. When appropriate, DOE initiates consultation with the U. S. Fish and Wildlife Service prior to implementing a proposed project.

Projects at the Paducah Site did not directly impact any of the 21 federally-listed or candidate species potentially occurring at or near the Paducah Site. Potential habitats of these species were also not significantly impacted. DOE initiated informal consultation with the U. S. Fish and Wildlife Service for several projects.

In 1995, DOE activities at the Paducah Site were conducted in full compliance with the Endangered Species Act.

\section{Floodplain/Wetlands Environmental Review Requirements}

Title 10, Part 1022 of the Code of Federal Regulations (10 CFR Part 1022) establishes procedures for compliance with Executive Order 11988, "Floodplain Management," and Executive Order 11990, "Protection of Wetlands." Activities (other than routine maintenance) proposed within 100-year floodplains or in wetlands first require that a notice of involvement be published in the Federal Register. DOE must then prepare a floodplain or wetlands assessment that evaluates potential impacts on the floodplains or wetlands and considers alternatives to avoid or lessen impacts. For floodplains, a floodplain statement of findings summarizing the floodplain assessment must be published in the Federal Register for public comment at least 15 days before beginning the project. DOE activities in "waters of the United States," which include wetlands, are likely to be subject to additional permit requirements administered by the Corps of Engineers and may require water quality certification from the KDEP.

\section{Environmental Compliance}


In 1995, one wetlands assessment was prepared and incorporated in a draft environmental assessment. In addition, a draft floodplain and wetlands assessment for site investigation and preliminary engineering activities was prepared. No floodplain or wetlands notices of involvement or floodplain statements of findings were published in the Federal Register for the Paducah Site. Also, DOE did not apply for any individual permits from Corps of Engineers or for any water quality certifications from the state.

DOE activities did not result in significant impacts to floodplains or wetlands at the Paducah Site in 1995.

\section{Farmland Protection Policy Act}

Prime farmland is generally defined as land that has the best combination of physical and chemical characteristics for producing crops of statewide or local importance. The Farmland Protection Policy Act of 1981 requires federal agencies to consider the effects of their proposed actions on prime farmland and consider any alternatives that would lessen impacts. When required, prime farmland surveys are conducted, and DOE consults with the U. S. Department of Agriculture Natural Resources Conservation Service, formerly the Soil Conservation Service. If conversion of prime farmland is anticipated, a farmland conversion impact rating form is completed and submitted to Natural Resources Conservation Service.

Informal consultations with Natural Resources Conservation Service did not result in submittal of any farmland conversion impact rating forms in 1995.

No prime farmland was converted at the Paducah Site during 1995.

\section{Clean Water Act}

The Clean Water Act (CWA) was established primarily through the passage of the Federal Water Pollution Control Act Amendments of 1972. The CWA established four major programs for control of water pollution: (1) a permit program regulating point-source discharges into U.S. waters, (2) a program to control and prevent spills of oil and hazardous substances, (3) a program to regulate discharges of dredge and fill materials into U.S. waters, and (4) a program to provide financial assistance for construction of publicly owned sewage treatment works.

\section{Kentucky Pollutant Discharge Elimination System}

The CWA applies to all non-radiological discharges to navigable surface waters. At the Paducah Site the regulations are applied through a KPDES permit for effluent discharges to Big Bayou and Little Bayou creeks. The Kentucky Division of Water (KDOW) issued KPDES Permit No. KY0004049 to Paducah DOE in September 1992. This permit became effective on November 1, 1992, and is enforced by the KDOW. In June 1993, the KDOW added USEC as a joint owner of the permit. At the request of the Paducah Site, the Commonwealth of Kentucky granted a stay of permit limits for $\mathrm{pH}$, metals, and temperature in October 1992. Paducah DOE is working with the KDOW to establish an agreed order concerning the final effluent limits for these parameters. All other conditions stated in the permit are in effect.

\section{Environmental Compliance}


As part of the DOE/USEC transition, DOE retained responsibility for any historic environmental problems that were the result of plant operations before July 1993. DOE also retained responsibility for 2 of the $18 \mathrm{KPDES}$ outfalls listed on the jointly held permit. Those two outfalls (017 and 018 ) are comprised solely of storm water runoff and contain no process wastewater. No exceedences of effluent limits occurred in 1995 at these two DOE outfalls. All of the analytical results for water generated from environmental restoration activities (i.e., DOE activities) are reviewed for KPDES compliance by Utility Services for USEC before being released to USEC KPDES outfall 001. Increased priority has been placed on erosion control at construction projects to greatly reduce the release of suspended solids from all construction projects at Paducah Site. The compliance rate was $100 \%$ for DOE's two outfalls with the KPDES permit during 1995. However, one exceedence was recorded in USEC outfall 011 for which DOE accepts responsibility. TCE from a historic spill percolated up out of the perched water table into the outfall in March during a period of heavy rainfall. In addition, two USEC outfalls (011 and 012) had noncompliances for PCB in effluents that were the result of historic PCB releases. DOE has responsibility for these noncompliances also.

Construction of a new DOE landfill was initiated in 1995. A KPDES Wastewater Discharge Permit (KY 0100072) was granted with an effective date of September 1, 1995. Discharges under the permit consist largely of storm water runoff. No discharge of water occurred in 1995 as the landfill was not completed and the capture/sedimentation lagoon associated with the landfill was not filled to the point of discharging.

\section{CWA NOVs}

Two CWA NOVs were received in 1995. One NOV addressed PCB discharges that occurred and were reported in 1994. The second NOV addressed PCB discharges during 1995.

\section{Toxic Substances Control Act}

The Toxic Substances Control Act (TSCA) was enacted in 1976 with a twofold purpose: (1) to ensure that information on the production, use, and environmental and health effects of chemical substances or mixtures is obtained by the EPA and (2) to provide the means by which the EPA can regulate chemical substances and/or mixtures.

\section{Polychlorinated Biphenyls}

The Paducah Site TSCA Compliance Program focuses on maintaining compliance with PCB regulations (40 CFR 761). The program concentrates on two major functions: (1) producing compliance documents and reports and (2) providing guidance to site organizations.

The Uranium Enrichment FFCA (UE-FFCA) between the EPA and DOE was signed in February 1992. To meet the compliance goals at the Paducah Site, the UE-FFCA is frequently revised and updated. A clarification package to revise the UE-FFCA was approved by EPA Headquarters in January 1995. Under this agreement, action plans have been developed and implemented for removal and disposal of large volumes of $\mathrm{PCB}$ material at the Paducah Site.

\section{Environmental Compliance}


The number of PCB transformers at the Paducah Site was reduced by 1 from the 68 reported for 1994 . Efforts to remove PCB capacitors continued in 1995. Table 2.2 shows progress of the capacitor-removal project during the year. Table 2.3 is a summary of $\mathrm{PCB}$ items in service at the Paducah Site as of the end of 1995. During 1995, procedures for Surface Radiological Characterization of Waste Streams were completed. Shipments of capacitors to off-site commercial disposal facilities began in 1995.

Major short-term plans include pursuing EPA approval for a PCB-drum wash station to decontaminate PCB containers. The annual PCB report, due July 1 , provides details of facility activities associated with the management of PCB materials. The annual report provides details from the previous year on all PCB items that are in use, stored for reuse, generated as waste, stored for disposal, or shipped off-site for disposal. All Paducah Site UE-FFCA milestones for 1995 have been completed.
Table 2.2 Status of large, high-voltage РСВ capacitors at Paducah in 1995

\begin{tabular}{cccc}
\hline $\begin{array}{c}\text { Building } \\
\text { location }\end{array}$ & $\begin{array}{c}\text { Beginning } \\
\text { balance, 1/1/95 }\end{array}$ & $\begin{array}{c}\text { Capacitors } \\
\text { removed }\end{array}$ & $\begin{array}{c}\text { New balance } \\
12 / 31 / 95\end{array}$ \\
\hline C-331 & 115 & 46 & 69 \\
C-333 & 999 & 63 & 936 \\
C-335 & 116 & 29 & 87 \\
C-337 & 2071 & 414 & 1657 \\
\cline { 2 - 4 } Total & 3341 & 524 & 2749 \\
\hline
\end{tabular}

The Paducah Site manages all nonradioactive contaminated PCBs in compliance with federal regulations. The facility operates equipment that contains PCB capacitors as well as transformers, electrical equipment, and other miscellaneous PCB equipment. Both radioactive and nonradioactive PCB wastes are stored on-site in storage units that meet TSCA and/or UE-FFCA compliance requirements. Nonradioactive PCBs are transported off site to EPA-approved facilities for disposal in accordance with regulatory requirements. Radioactively contaminated PCB wastes are authorized by the UE-FFCA for storage beyond one year on-site. Technology for the treatment and/or disposal of radioactively contaminated PCB wastes is being evaluated.

\section{PCB Capacitor Disposal Project}

On June 30, 1995, DOE granted Energy Systems approval to ship nonradioactive RCRA and TSCA waste off-site. By lifting the moratorium and approving the "Procedures for Surface Radiological Characterization DOE Waste Streams at the Paducah Gaseous Diffusion Plant," Energy Systems Waste Management began preparations to begin shipment of PCB capacitors. The PCB capacitor disposal project will dispose of 6,240 PCB capacitors. Specific approval to ship the PCB capacitors to an off-site vendor for treatment, storage, and disposal was granted by the Energy Systems Off-site Waste Release Board on November 30, 1995, and then by the Energy Systems Management Review Board on December 14, 1995. Beginning in November 1995, capacitors were taken out of storage, surveyed, repackaged, and certified for off-site release. Figure 2.1 shows PCB capacitors being repackaged for shipment. The post-moratorium shipping campaign began with a shipment of 276 capacitors to the Rollins Environmental Site Services facility in Deer Park, Texas on December 15, 1995. The PCB capacitor disposal project supports the Uranium Enrichment FFCA between DOE and the EPA.

\section{Environmental Compliance}




\section{TSCA NOVs}

No TSCA NOVs were received in 1995.

Table 2.3 Summary of PCBs and PCB items in service at Paducah at the end of 1995

\begin{tabular}{|c|c|c|c|}
\hline Type & $\begin{array}{l}\text { Number } \\
\text { in Service }\end{array}$ & $\begin{array}{l}\text { Volume } \\
\text { (gal) }\end{array}$ & $\begin{array}{l}\text { PCBs } \\
(\mathrm{kg})\end{array}$ \\
\hline PCB transformers & 67 & 96636 & 281,280 \\
\hline $\begin{array}{l}\text { PCB contaminated } \\
\text { transformers }\end{array}$ & 25 & 7679 & 4.3 \\
\hline $\begin{array}{l}\text { PCB contaminated } \\
\text { electrical equipment }\end{array}$ & 18 & 4704 & 5.0 \\
\hline PCB capacitors & 2749 & & \\
\hline PCB open systems $s^{a}$ & 3 & 235 & 10.9 \\
\hline
\end{tabular}

\section{Federal Insecticide, Fungicide, and Rodenticide Act}

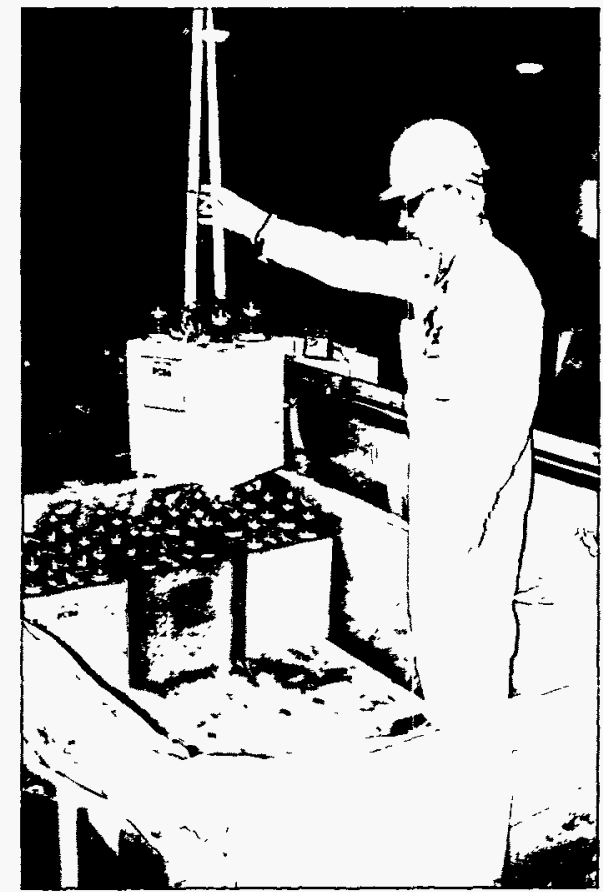

Figure 2.1 PCB Capacitor Shipment

The Federal Insecticide, Fungicide, and Rodenticide Act (FIFRA) regulates the manufacture, storage, and application of registered pesticides. No restricted-use pesticides are used by Paducah Site personnel. If application of a restricted-use pesticide at the plant should be necessary for DOE activities, a certified contractor will be used. General-use pesticides are applied by plant personnel in a manner consistent with product labeling; all product warnings and cautions are strictly adhered to. Applications of pesticides by PGDP and contractor personnel must be approved by the PGDP pesticide coordinator.

\section{FIFRA NOVs}

No FIFRA NOVs were received in 1995.

\section{Emergency Planning and Community Right-To-Know Act}

The Emergency Planning and Community Right-To-Know Act (EPCRA), also referred to as the Superfund Amendments and Reauthorization Act, Title III, requires reporting of emergency planning information, hazardous chemical inventories, and releases to the environment. EPCRA reports are submitted to federal, state, and local authorities. Executive Order 12856, signed in August 1993, subjects all federal agencies to EPCRA. The ongoing requirements of EPCRA are contained in Sections 304, 311, 312, and 313.

\section{Environmental Compliance}


- Section 304 requires reporting of off-site reportable quantity releases to state and local authorities.

- Section 311 requires that either material safety data sheets (MSDSs) or lists of the hazardous chemicals for which an MSDS is required be provided to state and local authorities for emergency planning purposes.

- Section 312 requires that a hazardous-chemical inventory be submitted to state and local authorities for emergency planning.

- Section 313 requires annual reporting of releases of toxic chemicals to the EPA and the state.

The Paducah Site had no releases subject to Section 304 notification requirements during 1995 . The Section 311 MSDS lists are updated frequently and provided to the appropriate officials. The Section 312 Tier II report of inventories for 1995, included 812,418,749 pounds of DUF 6 and 528,561 pounds of depleted uranium tetrafluoride (UF4) associated with DOE activities. Under Section 313, a single site-wide report was submitted by USEC. The two chemicals (chlorine and dichlorotetrafluoroethane) listed in the report are the responsibility of USEC.

\section{EPCRA NOVs}

No EPCRA NOVs were received in 1995.

\section{Clean Air Act}

Authority for enforcing compliance with the Clean Air Act (CAA) and subsequent amendments resides with the EPA and the Kentucky Division for Air Quality (KDAQ). The EPA generally enforces rules resulting from Title VI (Stratospheric Ozone Protection) of the Clean Air Act and regulates airborne radionuclide emissions under the National Emission Standards for Hazardous Air Pollutants (NESHAP) rule. The Paducah Site has an ongoing program to maintain compliance with all federal and state rules resulting from the CAA and its amendments.

\section{Clean Air Act Permit Status}

The Paducah Site DOE facilities had no significant point-source air emission sources that operated in 1995 and, therefore, had no emissions. In May 1993, the Paducah Site applied to the KDAQ for an operating permit for four sources that were thought to require a permit. These four sources consisted of two fluorescent bulb crushers that were to be installed in 1994 but were not used, a set of four TCE tanks that remained empty throughout 1995, and an air stripper for the Northwest Treatment Facility that began operating on August 28, 1995. In May 1994, the KDAQ notified the site that the state would not be issuing an operating permit because the uncontrolled and potential emissions of particulate matter from these four sources were calculated to be less than 25 and 5 tons per year, respectively, and because toxic materials emitted from the sources were calculated to be below their respective adjusted significant levels.

\section{Environmental Compliance}




\section{Asbestos NESHAP Program}

Numerous DOE facilities at the Paducah Site contain asbestos materials. Compliance programs for asbestos management include identification of asbestos materials, monitoring, abatement, and disposal. Procedures are maintained that delineate scope, roles, and responsibilities for maintaining compliance with EPA, Occupational Safety and Health Administration, and Kentucky regulatory requirements (no nonconformances with environmental protection standards were identified in 1995). In 1995, the Paducah Site disposed of 4 linear feet; 23,886 square feet; and 792 cubic feet of asbestos-containing material resulting from four abatement projects. These projects included abatement of nickel ingots, electrical switch gear, and maintenance activities in decontamination and decommissioning facilities.

The Nickel Ingot Asbestos Abatement Project provided for the removal of asbestos from 8,892 nickel ingots located on outside storage pads north of the C-746-A Waste Storage Building and adjacent to the C-746-P Scrapyard. Figure 2.2 shows a nickel ingot being removed from a conveyer system which takes the ingot (weighing 2000 to 3000 pounds) through the asbestos

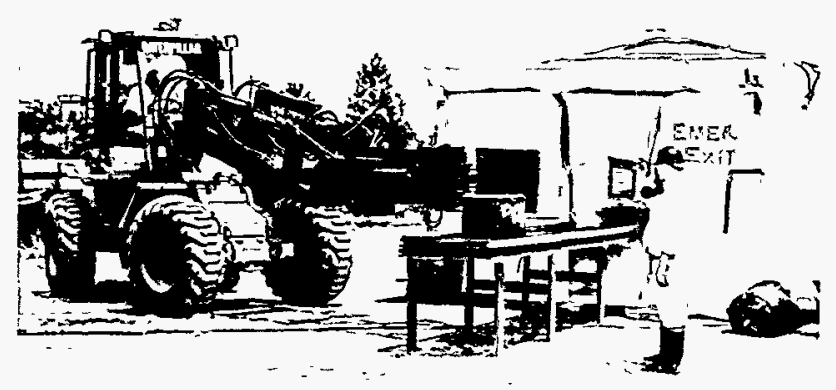

Figure 2.2 Nickel Ingot Asbestos Abatement Project handling activities.

abatement enclosure. The nickel ingots and storage locations were brought into compliance with NESHAP regulations. An additional 52 ingots were double wrapped in plastic and labeled appropriately due to the inability to abate them using industry standards. All of the ingots adjacent to C-746-A were relocated to the concrete storage pad adjacent to the C-746-P Scrapyard. Abatement activities were completed on September 28, 1995.

\section{Radionuclide NESHAP Program}

In 1989, 40 CFR 61 Subpart $\mathrm{H}$ was promulgated to regulate airborne radionuclides from DGE facilities. This regulation applies to the Northwest Treatment Facility, which began operation in August 1995, as well as fugitive emissions from Paducah Site DOE facilities such as dust from cylinder yard construction, gravel roads, and the scrapyards. The 1995 NESHAP report will be submitted in June 1996. Ambient air monitoring performed by Utility Services indicates that the combination of DOE and USEC point sources and fugitive emissions are insignificant.

\section{Clean Air Act Amendments of 1990}

These amendments are divided into six major titles. The titles that have the greatest impact on DOE activities at the Paducah Site are Title III, Hazardous Air Pollutants; Title VI, Stratospheric Ozone Protection; and Title V, Permitting.

\section{Environmental Compliance}




\section{Title III, Hazardous Air Pollutants}

Under the 1990 amendments, Section 112 of the CAA, requirements shifted from a pollutant-by-pollutant, health-based regulatory approach to regulation of categories of sources using technology-based standards. Examples of hazardous air pollutants that must be regulated by the EPA include volatile organic compounds such as benzene and metals such as chromium, cadmium, and manganese. The following summarizes key aspects of this legislation:

\section{A. Pollutants and Sources Subject to Regulation}

The CAA amendments completely overhauled the regulatory approach used for air toxics. Under the new approach, 189 substances are listed by Congress for regulation [Section 112(b)]. Substances can be added to or deleted from the list after rule making, but the EPA need not take any listing action with respect to these 189 substances.

Within one year of enactment, the EPA was required to publish a list of all major source categories and subcategories of the listed hazardous air pollutants, such as oil refineries and chemical plants [Section 112(c)]. Any stationary source emitting more than 10 tons per year of any of the listed substances or 25 tons per year of any combination of the substances is considered a major source and is subject to regulation. The EPA must examine other sources for regulation under an "area source" program, which must be developed within five years of enactment. The EPA issued a list of source categories for regulation under Section 112 in July 1992. The Paducah Site is not a major source by virtue of its individual or total Hazardous Air Pollutant emissions and is not currently regulated under Title III.

\section{B. Maximum Achievable Emission Limitations}

For each source category listed for regulation under Section 112, the EPA must promulgate standards requiring the installation of technology that will result in the "maximum degree of reductions" that it determines is "achievable." (This requirement has been referred to as the "maximum achievable control technology" or "MACT" standard.)

\section{Residual Risks}

Because the MACT standards are technology driven rather than health based, Congress was concerned that health risks could remain even after full implementation of MACT. As a result, the amendments provide for a second phase of regulatory controls aimed at protecting public health with an "ample margin of safety," similar to the pre-1990 Section 112 regulatory standard. This health-based inquiry would generally take place after MACT standards have been implemented for a source category [Section 112(f)].

\section{Control of Accidental Releases}

Title III requires the EPA to promulgate regulations to control and prevent accidental releases of regulated hazardous pollutants and any other extremely hazardous substance listed by the EPA [Section 112(r)]. Owners and operators of facilities where such substances are present in more than a threshold quantity will

\section{Environmental Compliance}


have to prepare risk management plans for each substance used at the facility. The Paducah Site does not store or process any of the hazardous pollutants at threshold quantities and will not require a Risk Management Plan.

\section{Title IV, Acid Rain}

One of the major new regulatory programs of the 1990 amendments concerns control of precursors of acid rain deposition, that is, sulfur dioxide $\left(\mathrm{SO}_{2}\right)$ and nitrogen oxides $\left(\mathrm{NO}_{x}\right)$. The centerpiece of this program is the establishment of an emissions allowance and trading regime for $\mathrm{SO}_{2}$. The Paducah Site has no sources that emit $\mathrm{SO}_{2}$ or $\mathrm{NO}_{x}$.

\section{Title V, Permitting}

The 1990 CAA amendments created an important new permitting program. Previously, operating permits were not required by federal law, though many state laws provided for such permits. Under Title $V$ of the 1990 amendments, however, the EPA is required to promulgate minimum requirements for state permit programs within one year of enactment [Section 502(b)]. The EPA issued these Title V rules in July 1992.

The Commonwealth of Kentucky applied for authorization to implement the Title V program with the federal EPA and received acceptance in December 1995. As the Paducah Site is not a major source, the $\mathrm{KDAQ}$ has agreed that a Title $\mathrm{V}$ permit is not required.

\section{Title VI, Stratospheric Ozone Protection}

In addition, Title VI of the 1990 amendments incorporates stratospheric ozone protection by restricting the production and consumption of chlorofluorocarbons, halons, methyl chloroform, carbon tetrachloride, and hydrochlorofluorocarbons. Halon, chlorofluorocarbons, methyl chloroform, and carbon tetrachloride have been phased out in DOE operations. The phaseout of hydrochlorofluorocarbons is to be accomplished over a longer period, stretching out to 2020-2040. Finally, the 1992 amendments require that production and consumption of hydrobromofluorocarbons be phased out beginning in 1996 and that methyl bromide be added to the list of controlled substances.

Since DOE has no such refrigeration units that contain more that 50 pounds, the only part of this regulation that applies to the Paducah Site is the requirement to control refrigerants from leaking systems and controls and record keeping at the time of disposal. DOE has implemented these controls and a record-keeping system.

\section{Kentucky/DOE Agreement in Principle}

Through the Kentucky/DOE Agreement in Principle (AIP), DOE provides Kentucky with financial and technical support for oversight of environmental monitoring, environmental restoration, waste management, emergency response, and public information programs at the Paducah Site. Requests for data and reports from AIP personnel have been entered into the Environmental Management and Enrichment

\section{Environmental Compliance}


Facilities Centralized Tracking System to allow tracking of these commitments. Efforts are currently under way to begin renegotiating the AIP, incorporating both DOE model language and the draft Paducah Site FFA.

\section{DOE Order Compliance}

The following section has been developed to discuss compliance with those environmental requirements not found in specific statutes or where DOE is primarily self-regulating. The following section provides compliance information for DOE Order 5400.1.

\section{DOE Order 5400.1, General Environmental Protection Program}

DOE Order 5400.1 establishes environmental protection program requirements, authorities, and responsibilities for DOE operations for assuring compliance with applicable Federal, State and local environmental protection laws and regulations, Executive orders, and internal DOE policies. The order specifically defines the mandatory environmental protection standards (including those imposed by federal and state statutes), establishes reporting of environmental occurrences and periodic routine reporting of significant environmental protection information, and provides requirements and guidance for environmental monitoring programs.

The internal environmental protection programs mandate the creation of several environmental reports. These reports include the 5-year plan required by the Office of Management and Budget Circular A-106, the annual site environmental report, and reports of significant nonroutine releases of hazardous substances consistent with DOE Order 5000.3B, Occurrence Reporting and Processing of Operations Information.

An environmental protection implementation plan is required and is updated annually as required by the order. The last update was issued in November 1995. This plan defines specific environmental objectives, including the means and schedules for accomplishment during the year.

DOE Order 5400.1 also requires an environmental monitoring plan that is to be reviewed annually and updated every three years. The environmental monitoring plan was revised and reissued in November 1995. The environmental monitoring plan defines effluent monitoring and environmental surveillance activities for the Paducah Site. Environmental media in pathways significant to the exposure of humans and the environment are included in the monitoring program, specifically, surface water, groundwater, sediment, and biological media.

\section{DOE Order 5400.5, Radiation Protection of the Public and the Environment}

DOE Order 5400.5 provides guidance and establishes radiation protection standards designed to protect the public and the environment against undue risk from operations of DOE and DOE contractors. The order requires that off-site radiation doses not exceed 100 millirem (mrem) per year for all pathways. During 1995, the worst-case estimated dose from Paducah Site operations was $1.08 \mathrm{mrem} /$ year, including a 1.07 mrem dose from sediments and direct radiation in Little Bayou Creek. Various modeling and dosecalculation activities are conducted to address the potential for multiple-pathway exposures of the public.

\section{Environmental Compliance}


The Paducah Site is also well below all applicable media-specific dose limits, such as the EPA limit of 10 mrem/year from airborne emissions and the DOE derived concentration guide for specific radionuclides in surface water discharges. The Paducah Site is in compliance with the requirements of DOE Order 5400.5.

\section{DOE Order 5820.2A, Radioactive Waste Management}

DOE Order 5820.2A provides that mixed waste and low-level waste be managed in a manner protective of health, safety, and the environment; minimizes generation; and complies with all applicable regulations and requirements. This order defines the requirements for treatment, storage, and disposal of radiological waste.

\section{Assessments}

Paducah Site environmental management programs are overseen by several organizations, both within and outside the DOE complex. Each year, numerous appraisals, audits, and surveillances of various aspects of the environmental compliance program are conducted. Table 2.4 contains a summary of the assessments conducted in 1995.

Table 2.4 Environmental assessments at the Paducah Site in 1995

\begin{tabular}{lll}
\hline \multicolumn{1}{c}{ Date } & \multicolumn{1}{c}{ Auditor } & \multicolumn{1}{c}{ Type } \\
\hline January 26 & KDAQ & Roller Smith Switchgear Asbestos Abatement C-335/C-337 \\
January 31 & KDWM & C-746-S Landfill \\
February 9 & $\begin{array}{l}\text { RCRA-EPA, } \\
\text { RCRA-State }\end{array}$ & Federal Facilities \\
February 27- & DOE & Environment, Safety, \& Health Programs \\
March 10 & DOE & Field Surveillance - North/South Diversion Ditch Construction Activities \\
April 4-7 & CWA-EPA, & Federal Facilities Compliance \\
March 22 & CWA-State & \\
March 22 & KDWM & Landfill records review and monthly inspection of C-746-S Landfill \\
April 4-5 & KDOW, EPA & $\begin{array}{l}\text { KPDES sample handling and analysis, records, discharge monitoring report } \\
\text { preparation }\end{array}$ \\
April 25 & DOE & TSCA Review \\
April 26 & KDWM & Monthly inspection of C-746-S Landfill \\
May & KDWM & Monthly inspection of C-746-S Landfill \\
May 10 & KDAQ & Nickel Ingot Asbestos Abatement Project \\
May 18 & KDAQ & Nickel Ingot Asbestos Abatement Project \\
\hline
\end{tabular}

\section{Environmental Compliance}




\begin{tabular}{|c|c|c|}
\hline May 25 & $K D A Q$ & Nickel Ingot Asbestos Abatement Project \\
\hline June 7 & $K D A Q$ & Nickel Ingot Asbestos Abatement Project \\
\hline June 29 & KDAQ & Nickel Ingot Asbestos Abatement Project \\
\hline August 3 & KDAQ & Nickel Ingot Asbestos Abatement Project \\
\hline August 3 & KDWM & Landfill Inspection \\
\hline August 8 & $\begin{array}{l}\text { DOE Inspector } \\
\text { General }\end{array}$ & Pollution Prevention Program \\
\hline August 16 & KDWM & Landfill Inspection \\
\hline August 24 & KDWM & Landfill Inspection \\
\hline August 30 & KDWM & Landfill Inspection \\
\hline September 11 & KDAQ & Air Sources Inspection \\
\hline September 12 & $\mathrm{KDAQ}$ & Nickel Ingot Asbestos Abatement Project \\
\hline September 20 & KDOW & Wastewater treatment Plant inspection \\
\hline October 2-12 & $\begin{array}{l}\text { Energy Systems } \\
\text { Oak Ridge }\end{array}$ & Integrated Corporate Audit \\
\hline October 26 & KDAQ & Nickel Ingot Asbestos Abatement Project \\
\hline November 21 & KDWM & RCRA Compliance and Waste Management Program \\
\hline November 22 & KDOW & KPDES Outfalls \\
\hline November 22 & KDWM & Landfill inspection \\
\hline
\end{tabular}

\section{Tiger Team Environmental Assessment}

The status of corrective actions resulting from the 1990 DOE Tiger Team assessment for Paducah Site is summarized in Table 2.5 .

The three open actions are: (1) Complete permanent storage facilities, (2) Begin storage of currently generated low-level scrap that cannot be decontaminated and is awaiting disposal in accordance with DOE 5820.2A, and (3) Receive approval of the WAG 24 Work Plan by NEPA/KDEP.
Table 2.5 Summary of Tiger Team Corrective Actions

\begin{tabular}{ccc}
\hline Environmental Findings & $\begin{array}{c}\text { Closed } \\
\text { Actions }\end{array}$ & $\begin{array}{c}\text { Remaining Open } \\
\text { Actions }\end{array}$ \\
\hline $\begin{array}{c}40 \\
(62 \text { total findings, } 40\end{array}$ & 37 & 3 \\
remained with DOE after \\
lease agreement with USEC $)$
\end{tabular}

\section{Environmental Compliance}




\section{Moratorium on Off-Site Shipment of Waste}

The off-site shipment moratorium, which came into effect in May 1991, placed severe limitations on management options for RCRA hazardous waste generated at Paducah. The Paducah Site worked to develop appropriate procedures for DOE Headquarters approval to allow resumption of off-site management options for radioactivity. On June 30, 1995, DOE granted Energy Systems approval to ship nonradioactive (non-surface contaminated) RCRA and TSCA waste off-site. 


\section{Environmental Compliance}




\title{
3. Environmental Program Information
}

\begin{abstract}
Environmental monitoring, environmental restoration, waste management, and depleted uranium hexafluoride cylinder management activities occur on-site. Numerous outreach programs are conducted to inform the public about these activities.
\end{abstract}

\section{Environmental Monitoring Program}

The environmental monitoring program at the Paducah Site consists of effluent monitoring and environmental surveillance. Requirements for routine environmental monitoring programs were established to measure and monitor effluents from Department of Energy (DOE) operations and to maintain surveillance on the effects of those operations on the environment and public health through measurement, monitoring, and calculation. The environmental monitoring program is also intended to demonstrate that DOE operations at the Paducah Site comply with DOE orders and applicable federal, state, and local regulations.

Before the DOE/United States Enrichment Corporation (USEC) transition (described in Section 1), DOE's primary mission at the Paducah Site consisted of enriching uranium. However, since the transition on July 1,1993 , DOE's mission at the site has become environmental restoration, depleted uranium hexafluoride cylinder management, and waste management. This change in mission has also changed the direction and emphasis of the environmental monitoring program. In November 1995, the Environmental Monitoring Plan, required by DOE Order 5400.1, General Environmental Protection Program, was reissued to address DOE operations exclusively.

\section{Environmental Restoration Program}

The goal of the Environmental Restoration Program is to ensure that releases from past operations and waste management at the Paducah Site are thoroughly investigated and that appropriate remedial action is taken for the protection of human health and the environment. In May 1994, the Paducah Site was added to the Environmental Protection Agency's (EPA) National Priorities List of the nation's hazardous waste sites that most require cleanup. Two federal laws, Resource Conservation and Recovery Act (RCRA) and Comprehensive Environmental Response, Compensation, and Liability Act (CERCLA), are the dominant regulatory drivers for environmental restoration activities at the Paducah Site. RCRA sets the standards for managing hazardous waste and requires permits to be obtained for DOE facilities that treat, store, or dispose of hazardous waste. CERCLA addresses uncontrolled releases of hazardous substances and requires cleanup of inactive waste sites.

\section{Environmental Restoration Program Activities}

The Environmental Restoration Program supports remedial investigations, decontamination and decommissioning of facilities no longer in use, projects designed to demonstrate advancements in remedial technologies, and related projects in order to take remedial action for the protection of human health and the environment. 


\section{Waste Area Groupings}

At the Paducah Site, solid waste management units (SWMUs) and areas of concern (AOCs) are surface sources of contamination. To expedite investigations, the SWMUs/AOCs are grouped together into waste area groupings (WAGs) based on certain criteria as follows:

- Common Remedial Technologies

- Common Geographic Locations

- Common Release Mechanisms

- Common Media Type

- Operating Units

\author{
Common Contaminant Sites \\ Common Operational Processes \\ Common Surface Water Drainage \\ Hydraulically-Connected Areas \\ Suspected Sources of Off-site Contamination
}

Some SWMUs/AOCs may be reassigned to other WAGs as a result of new investigations or developments in technology.

The WAGs are investigated as a RCRA facility to collect sufficient information on each SWMU to evaluate the extent of contamination and collect the data necessary to prepare a corrective measures study. The sampling strategy collects information only as needed to make risk-based and corrective action-based decisions. WAGs scheduled for action in the near future are listed in Table 3.1.

Table 3.1 WAG Activity During 1995

\begin{tabular}{|c|c|c|}
\hline WAG & SWMU & Status \\
\hline 1,7 & $\begin{array}{l}\text { C-746-K Inactive Sanitary Landfill, Fire Training Area } \\
\text { C-740 TCE Spill Site, C-611 1000-gal Diesel/Gasoline Tank } \\
\text { C-611 55-gal Gasoline Underground Storage Tank } \\
\text { C-611 50-gal Gasoline Underground Storage Tank } \\
\text { C-611 2000-gal Oil Underground Storage Tank } \\
\text { C-611 Unknown Size, Grouted Underground Storage Tank }\end{array}$ & $\begin{array}{l}\text { Field work was completed in June } 1994 . \\
\text { Preliminary characterization summary report } \\
\text { was submitted to EPA and Ky in Jan. 1995. A } \\
\text { draft feasibility study work plan was submitted } \\
\text { to EPA and KY in Jan } 1995 \text {. }\end{array}$ \\
\hline 6 & $\begin{array}{l}\text { C-400 TCE Leak Site } \\
\text { C-400 Technetium Storage Tank Area } \\
\text { C-400 Basement Sump, C-403 Neutralization Tank } \\
\text { C-400 to C-404 Underground Transfer Line }\end{array}$ & $\begin{array}{l}\text { An industrial hydrogeology utilities survey work } \\
\text { plan was submitted to EPA and Ky in Oct } 1995 .\end{array}$ \\
\hline 17 & 36 Different Concrete Rubble Piles & An RFI started in 1995. \\
\hline 22 & $\begin{array}{l}\text { C-747-A Burial Ground, C-747-A Burn Area } \\
\text { C-404 Low-Level Radioactive Waste Burial Ground } \\
\text { C-749 Uranium Burial Ground }\end{array}$ & $\begin{array}{l}\text { A feasibility study and proposed plan were } \\
\text { submitted to EPA and Ky in February and May } \\
\text { 1995, respectively. A Record of Decision was } \\
\text { signed in August } 1995 \text {. }\end{array}$ \\
\hline 23 & $\begin{array}{l}\text { C-747-C Oil Landfarm, C-728 Clean Waste-oil Tank } \\
\text { C-540-A PCB Waste Staging Area and Spill Site } \\
\text { C-541 -A PCB Waste Staging Area and Spill Site } \\
\text { C-340 PCB Transformer Spill Site, C-611 PCB Spill Site } \\
\text { C-728 Motor Cleaning Facility }\end{array}$ & $\begin{array}{l}\text { A treatability study report was submitted in } \\
1995 .\end{array}$ \\
\hline
\end{tabular}




\section{Operable Units}

Once a WAG is prioritized and the corresponding Remedial Investigation/Feasibility Study (RI/FS) identifies a specific problem warranting action, a remedy is selected and implemented. The selection and implementation of remedies, which are documented in the Record of Decision (ROD) and Action Memorandums, are referred to as operable units (OUs). OUs may address geographic portions of a site, specific site problems, or initial phases of an action. They may also consist of sets of actions performed over time. Integrator units will be investigated and remediated independently from the SWMUs/AOCs because sources of contamination are uncertain and involve several WAGs. Contaminated groundwater is grouped within a groundwater integrator unit. Likewise, contaminated surface water is grouped within a surface water integrator unit.

\section{Groundwater Integrator Unit}

The groundwater integrator unit is discussed in Section 9.

\section{Northwest Treatment Facility}

The Interim Remedial Action of the Northwest Treatment Facility was documented in a ROD signed by DOE and the EPA in July 1993. The ROD was concurred with by the Commonwealth of Kentucky. The interim remedial action began operations on August 28, 1995. The remedial action consists of two extractions well fields, transfer pipelines, a treatment facility, and appurtenant equipment. The interim action, which is currently a two year pilot phase operation, is designed to remove the contaminants of trichloroethylene (TCE) and technetium-99 $\left({ }^{99} \mathrm{Tc}\right)$. Figure 3.1 provides a view of the equipment in the Northwest Treatment Facility.

TCE is removed by an air stripping process. The TCE is volatilized into a large volume of air that comes into contact with the contaminated groundwater during the treatment process. Activated carbon beds are then used to remove the TCE, which is entrained in the air stream before the air is released to the atmosphere.

${ }^{99} \mathrm{Tc}$ is removed by an ion exchange process. During the treatment process the ${ }^{99} \mathrm{Tc}$ in the groundwater is exchanged for a chlorine ion, which is contained in the ion exchange resin held in treatment vessels.

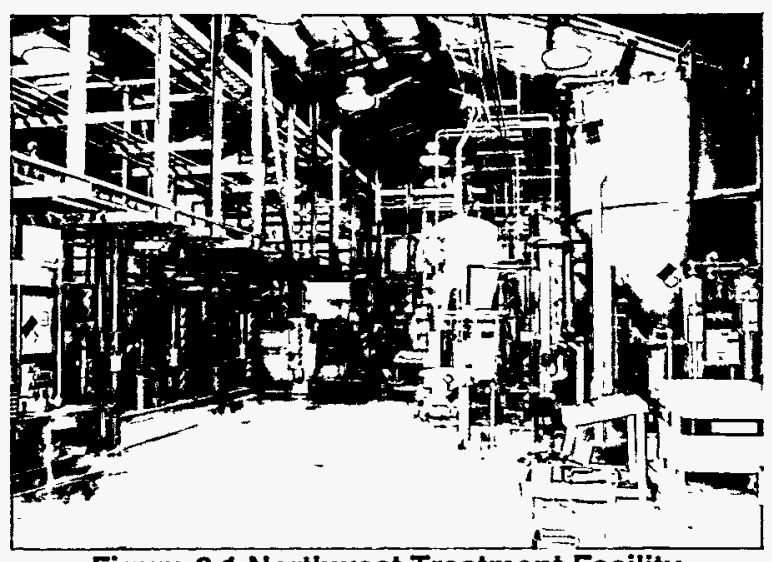

Figure 3.1 Northwest Treatment Facility

The treatment facility has extracted and treated approximately 37,000,000 gallons of contaminated groundwater (through January 1996) at a treatment rate of 166 gallons per minute. The treatment facility has been on-line 94 percent of the time since startup, exceeding the goal of 85 percent. The interim remedial action has consistently met the groundwater treatment goals as documented in the ROD of 5 parts per billion (ppb) TCE and 900 picocuries per liter of ${ }^{99} \mathrm{Tc}$. The groundwater, after treatment, is released through a Kentucky Pollutant Discharge Elimination System (KPDES) permitted outfall. Radiological emissions from this facility are shown in Chapter 4. 


\section{Decontamination and Decommissioning}

Decontamination and decommissioning is the disposition of facilities and other structures contaminated with radiological and hazardous material. Facilities are accepted for decontamination and decommissioning when they are no longer required to fulfill a site mission. Legacy contamination on the structure, floors, walls, and equipment constitutes a potential for release to the environment if not appropriately managed in the near term and ultimately removed. Two major facilities comprising approximately $46,450 \mathrm{~m}^{2}(500,000$ $\mathrm{ft}^{2}$ ) have been accepted for decontamination and decommissioning. These facilities are the C-340 metal reduction plant complex, where uranium hexafluoride $\left(\mathrm{UF}_{6}\right)$ was converted to uranium and fluorine, and the $\mathrm{C}-410$ feed plant complex, where uranium dioxide $\left(\mathrm{UO}_{2}\right)$ was converted to $\mathrm{UF}_{6}$. Major contaminants at these facilities include depleted uranium, normal uranium (at C-410 only), uranium tetrafluoride, polychlorinated biphenyls (PCB), asbestos, and lead paint. Activities performed during the year include surveillance and maintenance of the structures to ensure containment of residual materials, removal and storage of some legacy wastes, and decontamination and decommissioning project planning for future implementation.

\section{Technological Demonstrations}

The Environmental Restoration Program actively supports demonstrating new remediation technologies that have been developed by private industry. These demonstrations serve as advanced "field tests" for the companies' products. Demonstrations were performed for technologies such as Lasagna ${ }^{\circledR}$, Surfactant Injection Characterization, and Iron Filings. These technology demonstrations are discussed in more detail in Section 9.

\section{Waste Management Program}

The Paducah Site Waste Management Program directs the safe storage, treatment, and disposal of waste generated before July 1, 1993 (i.e., "legacy" wastes), and waste from current DOE activities. The primary objective of the program is to ensure that waste materials do not migrate into the environment. Waste managed under the program is divided into six categories: low-level radioactive, hazardous, mixed, PCB and PCB contaminated, asbestos, and conventional sanitary waste:

- Low-level radioactive waste - radioactive waste not classified as high-level or transuranic and that does not contain any components regulated by RCRA or Toxic Substances Control Act (TSCA).

- Hazardous waste - waste that contains one or more of the wastes listed under RCRA or that exhibits one or more of the four RCRA hazardous characteristics: ignitability, corrosivity, reactivity, and toxicity.

- Mixed waste - waste containing both hazardous and radioactive components. Mixed waste is subject to RCRA, which governs the hazardous components, and to additional regulations that govern the radioactive components.

- $\quad P C B$ and $P C B$-radioactive wastes - waste containing PCBs, a class of synthetic organic chemicals including 209 known isomers, each with from 1 to 10 chlorine atoms on a biphenyl ring. Under TSCA regulations, PCB manufacturing was prohibited after 1978. However, continued use of PCBs is allowed provided that the use does not pose a risk to human health or the environment. Disposal of all PCB materials is regulated.

- Asbestos waste - asbestos-containing materials from renovation and demolition activities.

- Sanitary waste - waste that is neither radioactive nor hazardous. Solid sanitary waste is basically refuse and is disposed in landfills. 
Requirements for meeting waste management regulatory objectives are varied and complex because of the variety of waste streams generated by DOE activities. The goal, however, is to comply with all current regulations while planning actions to comply with anticipated future regulations.

Compliance for waste management activities involves meeting EPA and state regulations and DOE orders. In addition to compliance with these regulations, supplemental policies are enacted for management of radioactive, hazardous, and mixed wastes. These policies include reducing the amount of wastes generated; characterizing and certifying waste before it is stored, processed, treated, or disposed; and pursuing volume reduction and use of on-site storage, when safe and cost effective, until a final disposal option is identified.

\section{Waste Minimization}

The Waste Minimization/Pollution Prevention (WMP2) Program at the Paducah Site provides guidance and objectives for minimizing solid and hazardous waste generation. Guidance for the program comes from regulations promulgated by RCRA, the Pollution Prevention Act, applicable state and EPA rules, and DOE and executive orders.

The program is striving to meet its goals with the following strategy:

$\because$

source reduction, reuse of materials, and recycling.

The WMP2 Program has the following objectives:

- identifying waste reduction opportunities,

- $\quad$ establishing WMP2 goals,

- establishing employee awareness of WMP2,

- $\quad$ initiating WMP2 technologies into ongoing projects,

- identifying WMP2 responsibilities and resource requirements, and

- $\quad$ tracking and reporting WMP2 results.

The WMP2 Program is administered by the Waste Minimization Program manager, who is part of the Environmental Management Group. Record keeping and reporting information is obtained through the Waste Management Group.

In conjunction with Environmental Management Group and the Waste Management Group, the Waste Minimization Program manager identifies waste streams that are high-priority minimization or reduction candidates based on the following factors:

- availability of storage space,

- waste stream hazard,

- availability of treatment and disposal facilities (both on- and off-site),

- regulatory compliance issues, and

- management and disposal costs. 


\section{Program Results}

Recycling efforts, in 1995, included 16,036 pounds white office paper and 535 pounds aluminum cans. Other initiatives included implementing a Pilot Generator Set-Aside Fee Program that taxes waste generators for waste generated during projects. Another accomplishment was the funding of a Photocatytic Reactor for treatment of wastewater through the Energy Systems High Investment Value Program. This project greatly reduces the amount of secondary waste generated during the treatment of wastewater.

\section{Vortec Vitrification Technological Demonstration}

In March 1995, Paducah Site was selected to be the host site for the Vortec vitrification demonstration. DOE has funded the development of vitrification technology for several years. The Vortec transportable process is an innovative use of glass-making technology. The vitrification unit has the potential to process low-level, PCB, and hazardous waste and soils into a glass matrix. The glass matrix containing radionuclides and heavy metals is more stabile and correspondingly better suited for disposal. DOE is preparing a location at the Paducah Site where the Vortec demonstration will be sited.

\section{Depleted Uranium Hexafluoride Cylinder Program}

During the development and operation of the enrichment process: containers, support equipment, and support facilities were designed, constructed, and used as a system to store, transport, and process the depleted $\mathrm{UF}_{6}\left(\mathrm{DUF}_{6}\right)$. Solid $\mathrm{DUF}_{6}$ was stored in large metal cylinders. After a significant inventory was produced, outdoor storage facilities ("cylinder yards") evolved independently at the sites. Cylinder yards are constructed of either concrete, compacted gravel, or asphalt over gravel. The handling equipment used to stack these cylinders has also evolved, from mobile cranes to specifically designed machines that grasp and lift the cylinder with hydraulic lines.

The "mission" of the DUF 6 Cylinder Program is to safely store the DOE-owned DUF 6 inventory until its ultimate disposition. The $\mathrm{DUF}_{6}$ Cylinder Program Management Plan was established to meet the program mission. The plan comprises components (such as $\mathrm{DUF}_{6}$, cylinders, cylinder yards, cylinder-handling equipment, personnel, and financial resources) and activities (such as operations, management processes, and administration).

The congressional adjustment of DOE's mission from uranium enrichment to uranium inventory management (storage and utilization) has transformed the previous management plan from design, construction, and operation phases to a storage or standby phase. The Program Management Plan for which $\mathrm{DOE}$ is responsible has been realigned to containment and use of a finite inventory of DUF 6 . The various types of construction and the subsequent deterioration of the yards have led to substandard storage conditions of many of the cylinders. The variety of cylinder designs that have evolved over the years has resulted in varying corrosion rates. These two main factors led to the need for long term corrosion monitoring of the cylinders.

Potential risks to people and the environment posed by $\mathrm{DUF}_{6}$ storage as it is managed are low. The DUF 6 is stored as a crystalline solid. When $\mathrm{DUF}_{6}$ is exposed to the atmosphere, hydrogen fluoride and uranium reaction products form. The uranium by-products form a hard crystalline solid, which acts as a self-sealant. The hazard potential of the $\mathrm{DUF}_{6}$ is primarily chemical toxicity from hydrogen fluoride, rather than radiological hazard. 
After visiting the DOE sites (Paducah, Portsmouth, and K-25) in 1994 and 1995, the Defense Nuclear Facilities Safety Board (DNFSB) issued Recommendation 95-1 and a supporting technical report. That report addressed the improved safety of cylinders containing DUF 6 . DNFSB "Recommendation 95-1 on Depleted Uranium" recommended the following:

- Start an early program to renew the protective coating of cylinders containing the $\mathrm{DUF}_{6}$ from the historical production of enriched uranium.

- Explore the possibility of additional measures to protect these cylinders from the damaging effects of exposure to the elements, as well as any additional handling that may occur.

- Institute a study to determine whether a more suitable chemical form should be selected for longterm storage of the depleted uranium.

On June 29, 1995, DOE formally accepted Recommendation 95-1 and emphasized five focus areas for DOE response:

- Removing cylinders from ground contact and keeping cylinders from further ground contact;

- Relocating all cylinders into adequate inspection configuration;

- Repainting cylinders as needed to avoid excessive corrosion;

- Updating handling and inspection procedures and site-specific Safety Analysis Reports; and

- Completing an ongoing study that will include an analysis of alternative chemical forms for the material.

On October 16, 1995, DOE submitted an Implementation Plan that incorporated complete and near-terms actions in accordance with these five focus areas. The Implementation Plan also committed to managing the $\mathrm{DUF}_{6}$ Cylinder Program using a Systems Engineering Approach. The approach is being developed concurrent with field response actions and is enhanced through an open dialogue among DNFSB staff and DOE and Energy Systems personnel. The Implementation Plan specifies the following interim and final deliverables and defines their respective content to establish an operative Systems Engineering process for the continued improvement of $\mathrm{DUF}_{6}$ management:

- System Requirement Document - identifies the system requirements;

- System Engineering Management Plan - identifies organization, direction, and controls for system integration;

- Engineering Development Plan - identifies development actions, costs, and schedules for technical improvements;

- $\quad \mathrm{DUF}_{6}$ Cylinder Program Management Plan - identifies costs, schedules, and controls for operating the system and implementing required actions; and

- Approved Safety Analysis Reports - defines the safety envelope.

The mission of the DUF ${ }_{6}$ Cylinder Program is to safely store the DOE-owned DUF 6 inventory until its ultimate disposition. The system was established to meet the Program mission and is the means by which containment is achieved. The system comprises components (such as the UF 6 cylinders, cylinder yards, cylinder handling equipment, personnel, and financial resources) and activities (such as operations, management processes, and administration). 
The system includes several operational functions to maintain containment of the DUF6. These operational functions are:

- Surveillance and Maintenance,

- Handling and Stacking,

- Contents Transfer, and

- Off-Site Transport

DOE is upgrading the quality of the cylinder yards help maintain the integrity of the cylinders. C-745-S cylinder yard was upgraded and paved in 1995, see Figure 3.2. Fewer cylinders will be stored in the refurbished yards resulting in easier access for inspections to detect corrosion on the cylinders. For this reason DOE is proposing construction of a new

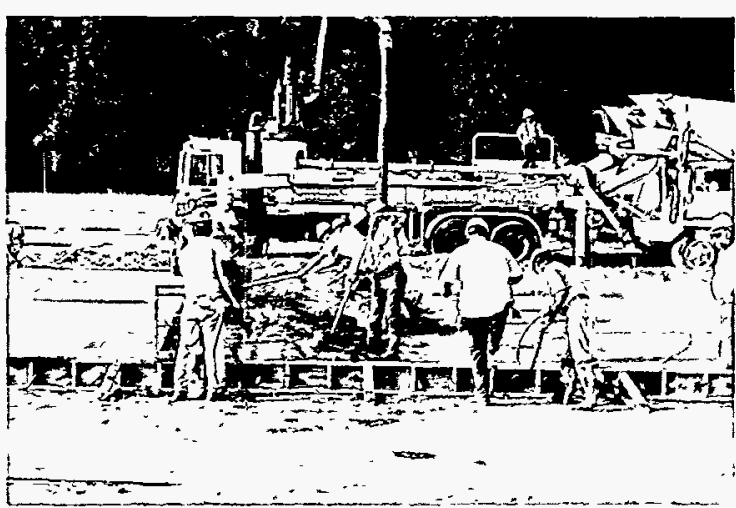

Figure 3.2 C-745-S Cylinder Yard Construction cylinder yard C-745-T.

\section{Technical Information Exchange}

Paducah Site Energy Systems representatives attend both DOE-sponsored and independent information exchange workshops such as the annual DOE Model Conference, quarterly multi-plant task team meetings, and professional conferences.

\section{Public Awareness Program}

A comprehensive community relations and public participation program on DOE activities exists at the Paducah Site. The purpose of the program is to conduct a proactive public involvement program, with outreach components, to foster a spirit of openness and credibility among local citizens and various segments of the public. The program is also geared to provide the public with opportunities to become involved in decisions affecting environmental issues at the site.

\section{Information Bulletins, Fact Sheets, and Public Briefings}

During 1995, a general information bulletin was published on environmental issues and cleanup activities for DOE operations. The bulletin was distributed to approximately 4,000 recipients throughout the region. Fact sheets on several topics, including the Vortec pilot waste vitrification project, the "Lasagna" insitu soil remediation pilot project, Site Specific Advisory Board (SSAB), and the site depleted uranium cylinder management program were also published and distributed.

A total of seven public meetings and two news conferences were held during 1995. Some of the meetings were general in nature, covering a range of environmental restoration and waste management topics, while others dealt with specific issues, such as the Waste Management programmatic EIS, Future Land Use and the feasibility and desirability of forming a SSAB at Paducah. Site personnel participated in the Annual Governor's Conference on the Environment in Lexington, Kentucky. In addition to technical papers presented by site personnel, Public Affairs operated an information booth at the Kentucky Environmental Expo, conducted in conjunction with the conference. 


\section{Community/Educational Outreach}

DOE and Energy Systems Public Affairs sponsored 25 separate educational and community outreach activities during 1995, involving about 70 employees in working with area schools and civic groups. Four facility tours were also conducted, including a tour of the Northwest Treatment Facility by a group of scientists and regulators from the former Soviet republic of Kahkistan.

\section{Earth Day}

DOE, Energy Systems Public Affairs and the Kentucky Division of Fish and Wildlife Resources jointly sponsored, planned and implemented the 1995 Earth Day activities. The four-day event involved about 1,000 sixth- grade students from area school systems. A wide variety of environmental educational programs were available, see Figure 3.3, using both the West Kentucky Wildlife Management Area and DOE property. Many of the activities were hands-on, in which the students made decisions and took actions regarding hypothetical environmental problems.

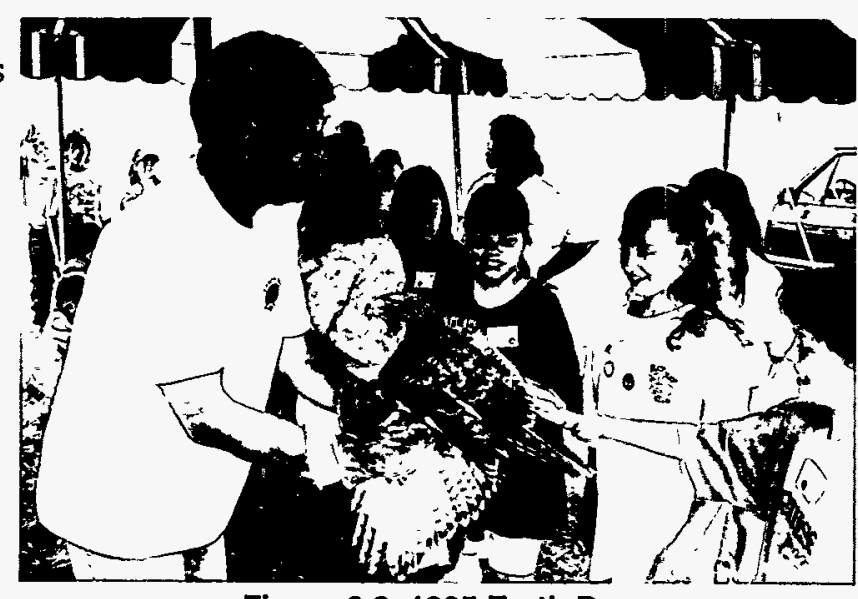

Figure 3.3 1995 Earth Day

\section{Site Specific Advisory Board}

In early 1995, DOE, using an independent facilitator, assessed the need for, then began the process of establishing a Site Specific Advisory Board (SSAB) at Paducah. The board will be comprised of members representing virtually all those interested in DOE activities at the Paducah Site. The facilitator conducted public meetings to assess the need. When the need was established, he appointed a working group comprised of individuals with diverse backgrounds and interests. His selection was based on a number of factors, including personal interviews. The working group established membership criteria and developed a mission statement for an SSAB, solicited applications, then selected potential candidates for membership. Final approval to officially charter the board under the Federal Advisory Committees Act is expected to be received for DOE Headquarters.

\section{Environmental Advisory Committee}

The Paducah Environmental Advisory Committee was chartered in 1986 as part of a program to solicit expert and general public input on environmental issues at the Paducah Site. Committee members include scientists, academics, business people, and members of the general public. The committee is currently composed of five members who meet quarterly for an entire day to be briefed on a wide range of issues and to provide meaningful input on several projects. 


\section{PCB Strategy}

\section{Regulatory Background}

On August 31,1990, a Notice of Violation (NOV) was issued from the Kentucky Division of Water (KDOW) to the Paducah Site for degrading the waters of the Commonwealth through discharges of PCBs which result in water quality standards being exceeded. PCBs were found in fish tissue downstream of Paducah Site outfalls on Little Bayou Creek, exceeding the Federal Drug Administration level of 2 parts per million (ppm).

Efforts to identify the source of the PCBs were conducted at the site; however, studies did not identify a continuous source of PCB releases at the Paducah Site.

\section{Summary of Regulatory Reporting and Associated Correspondence}

On August 16, 1994, KDOW issued a NOV to the Paducah Site for KPDES permit violation of PCB at Outfall 011 during April, May, and June 1994.

On November 15, 1994, KDOW issued a NOV and Demand Letter to the Paducah Site for KPDES permit violations of PCB at Outfall 011 during the months of July, August, and September 1994.

On December 14, 1994, a response to the Demand Letter was submitted to KDOW by DOE. The response identified short term actions such as routine cleaning of lift stations, installation of erosion controls at SWMUs with known PCB contamination, and evaluations of other options for Outfall 011. In addition, DOE proposed continued discussions as to the proper reporting of PCB concentrations.

The response from KDOW dated December 19, 1994, in regard to the Demand Letter response, stated that an Agreed Order would not be pursued by KDOW because long- term remediation is being addressed through the existing ACO and the Federal Facilities Agreement (FFA). KDOW also stated that NOVs will continue to be issued, as necessary, to document ongoing exceedences of KPDES permit limits.

On January 18, 1995, DOE sent a letter to the EPA Region IV and the KDEP with proposed FFA language for their consideration. The proposed FFA language would allow surface water discharges associated with contamination resulting from past operations to be addressed under the FFA and not the KPDES permit.

On January 20, 1995, DOE sent a letter to KDOW as a follow-up to the Demand Letter identifying actions the Paducah Site is proposing to correct the problem. The specific actions are covered under Action Items in this Summary.

On February 13, 1995, KDOW issued a NOV to the Paducah Site for KPDES permit violations of PCB exceedences at Outfall 012 during August and October 1994. The levels reported to the state for August were 0.08 microgram per liter $(\mu \mathrm{g} / \mathrm{l}$ ) and October $0.28 \mu \mathrm{g} / 1$ (detection limits were modified to the $0.17 \mathrm{ppb}$ level on the KPDES reports beginning October 1994).

On February 27, 1995, a response to the NOV was sent to KDOW from DOE. 
On April 20, 1995, exceedences occurred in Outfalls 011 and 012 at levels of 0.29 and $0.26 \mathrm{ppb}$, respectively.

On June 21, 1995, an exceedence of $0.17 \mathrm{ppb}$ occurred at Outfall 012. This value was reported as an exceedence in error. PCB values for June at Outfall 012 sample were $0.14 \mathrm{ppb}$ for Aroclor 1242 and 0.03 $\mathrm{ppb}$ for Aroclor 1260. Both are below the quantifiable detection limit. The summation of the values, $0.17 \mathrm{ppb}$, is at the quantifiable detection limit and was reported as a detected value. Laboratory personnel have been instructed as to the proper quantifiable detection limits to be reported.

On August 24, 1995, KDOW issued a NOV to the Paducah Site for KPDES permit violation of PCB at Outfall 012 during April and June 1995.

On September 27, 1995, DOE sent a response to KDOW regarding the NOV of August 24, 1995. In the response, DOE states that in their opinion, the intermittent detection of PCBs at some outfalls are due to legacy issues and are unrelated to the current operation of the plant.

The 1995 Summary of Paducah Site PCB exceedences reported as of November 30, 1995:

Outfall 0111 Daily Maximum and 1 Monthly Average

Outfall 0122 daily Maximums and 2 Monthly Average

\section{Activities in 1995}

1. Studies to identify sources of PCBs continued in 1995. A PCB sampling project using Semi-Permeable Membrane Devices (SPMDs) was conducted in March and October 1995 to determine the source of PCB contamination in plant outfall ditch sediments and receiving stream sediments downstream of the outfalls.

2. Monthly inspections and as needed cleaning of the outfall lift stations continued through 1995

3. The 011 ditch was lined with bentonite in June of 1995 to reduce possible mobilization of sediments. A maintenance coat was reapplied in October.

4. Completed the installation of silt fencing around SWMUs 56 and 80.

5. Characterized ditch sediments in outfalls 011 and 012.

\section{Results}

Characterization of specific PCB aroclors in sediments of the outfall ditches indicate the sources are at least in part independent of each other. SPMDs results indicate a possible source south of the C-333 Process Building. The area around C-333-A (SWMU 70) is the site of a historic PCB spill. The main aroclor from this spill site is found in outfall 012 but is not present in outfall 011 . Analysis of sediments from the outfall lift station cleaning events in 1995 indicate PCB detectable sediments are being accumulated in the lift stations. 


\title{
4. Radiological Effluent Monitoring
}

\begin{abstract}
For all but two outfalls (017 and 018) at the Paducah Site, radiological liquid effluent monitoring is under the jurisdiction of the United States Enrichment Corporation. The two outfalls retained by the Department of Energy (DOE) contain only rainfall runoff and are monitored for radionuclides known to be released or to have been present at the site historically. Concentrations for the radionuclides measured (uranium and technetium) for both DOE outfalls were within the acceptable limits set by DOE and by state and federal standards. DOE began operation of one point source for radionuclides in airborne effluents during 1995.
\end{abstract}

\section{Introduction}

Monitoring of radioactivity in liquid effluents is described in the Paducah Site Environmental Monitoring Plan (LMES 1995). Sampling and analytical activities are the responsibility of Lockheed Martin Energy Systems (Energy Systems), but these services are procured from Lockheed Martin Utility Services (Utility Services). The Environmental Monitoring Section, part of the Utility Services Environmental and Waste Management Division, provides sampling support; and the analytical laboratory, part of the Utility Services Production Support Division, provides analytical measurements. Effluents are monitored for radionuclides known to be emitted or to have been present at the site. Dose calculations and comparisons are discussed in Section 6. Applicable regulations are discussed in the following sections on airborne and liquid effluents.

\section{Airborne Effluents}

As a result of the formation of United States Enrichment Corporation (USEC) in 1993, the Department of Energy (DOE) leased the enrichment operations facilities at the Paducah Gaseous Diffusion Plant (PGDP) to USEC. In this lease, USEC assumed responsibility for all existing radionuclide point-source discharges. A small number of fugitive emission sources, such as roads and scrap metal piles, that could act as radionuclide emission sources were retained by DOE. On August 28, 1995, DOE began operation of its only radionuclide point source, the Northwest Treatment Facility. The facility is located at the northwest corner of the PGDP security area. The facility consists of an air stripper to remove volatile organics from water and an ion exchange unit for the removal of technetium- $99\left({ }^{99} \mathrm{Tc}\right)$. The air stripper is located upstream of the ion exchange unit. Emissions of ${ }^{99} \mathrm{Tc}$ were estimated using the analysis of the influent groundwater and the water leaving the air stripper. The ${ }^{99} \mathrm{Tc}$ concentration in the influent and effluent of the air stripper and the quantity of the water passing through the stripper were used to estimate the total quantity of ${ }^{99} \mathrm{Tc}$ emitted from the facility. Table 4.1 shows influent concentration, effluent concentration, the difference for each sampling period, gallons of water processed and the total curies of ${ }^{99} \mathrm{Tc}$ emitted from the facility.

\section{Applicable Regulations}

DOE Order 5400.1, General Environmental Protection Program, requires that effluent monitoring be conducted at all DOE sites. DOE Order 5400.5, Radiation Protection of the Public and the Environment, 
sets annual dose standards for members of the public of 10 millirem (mrem) per year from airborne releases and 100 mrem/year through all exposure pathways resulting from routine DOE operations. Radiological airborne releases are also regulated by the Environmental Protection Agency (EPA) under Title 40 of the U.S. Code of Federal Regulations, Part 61 (40 CFR 61), Subpart H, which covers radionuclide emissions, other than radon, from $\mathrm{DOE}$ facilities. This regulation was amended in 1989 to include specific sampling requirements for each emission point with the potential to emit radionuclides resulting in an effective dose equivalent of 0.003 mrem to the most affected off-site resident. When determining potential emissions, it is assumed that air pollution abatement devices do not exist, but that the facility is otherwise operating normally.

Per 40 CFR 61 Subpart H, DOE must report radionuclide emissions by June $30^{\text {th }}$ of each year to the EPA via a National Emission Standards for Hazardous Air Pollutants (NESHAP) Report. The EPAapproved methodologies for sampling and calculations must be used to address effluents. Under the Comprehensive Environmental Response, Compensation, and Liability Act (CERCLA), a Record of Decision (ROD) was signed July 22, 1993, for the Northwest Treatment Facility. Although under CERCLA, administrative requirements are not required, DOE has continued to supply all related permitting and reporting documentation to regulators as prior to the Paducah Site being listed on the National Priorities List (NPL). The Operations and Maintenance Plan approved by the EPA in March 1995, described sampling and methodologies to used be at the Northwest Treatment Facility. The sampling protocol has been used to develop a mass balance differential to quantify the radionuclide stack effluent from the facility. The analysis of the water before and after the air stripper 
stack, see Table 4.1, provides a much more accurate measure of airborne discharges than actual stack measurements due to the low, practically immeasurable radionuclide airborne effluents associated with the facility.

\section{Airborne Effluent Results}

In preparing the Annual 1995 NESHAP Report that summarizes the airborne radionuclide emissions from the entire site, a mass balance from the Northwest Treatment Facility air stripper was used to calculate the total curies of radionuclide emissions from the operation. In 1995, releases to the atmosphere are calculated to be $5 \times 10^{-3}$ curies which via NESHAP modeling results in an off-site dose to the maximally exposed individual of 0.003 mrem effective dose equivalent. The collective effective dose equivalent (person-rem/yr) within a 50 mile radius was 0.04 .

\section{Liquid Effluents}

In addition to radiological parameters on the Kentucky Pollutant Discharge Elimination System (KPDES) permit, specific radionuclide analysis and indicator gross activity analyses are conducted on liquid effluent samples, see Figure 4.1. Grab samples and composite samples at various frequencies are used to measure discharges. DOE retained only two outfalls that are listed on the KPDES permit (017 and 018), and those contain only rainfall runoff from the plant. In August 1995, operations of the Northwest Treatment Facility began. The facility pumps contaminated groundwater from the regional gravel aquifer, treats it to remove trichloroethylene (TCE) and ${ }^{99} \mathrm{Tc}$, and then discharges it as surface water via KPDES outfall 001 . Outfall 001 is a USEC leased outfall. The Northwest Treatment Facility is a small contributor to the outfall and effluents are insignificant.

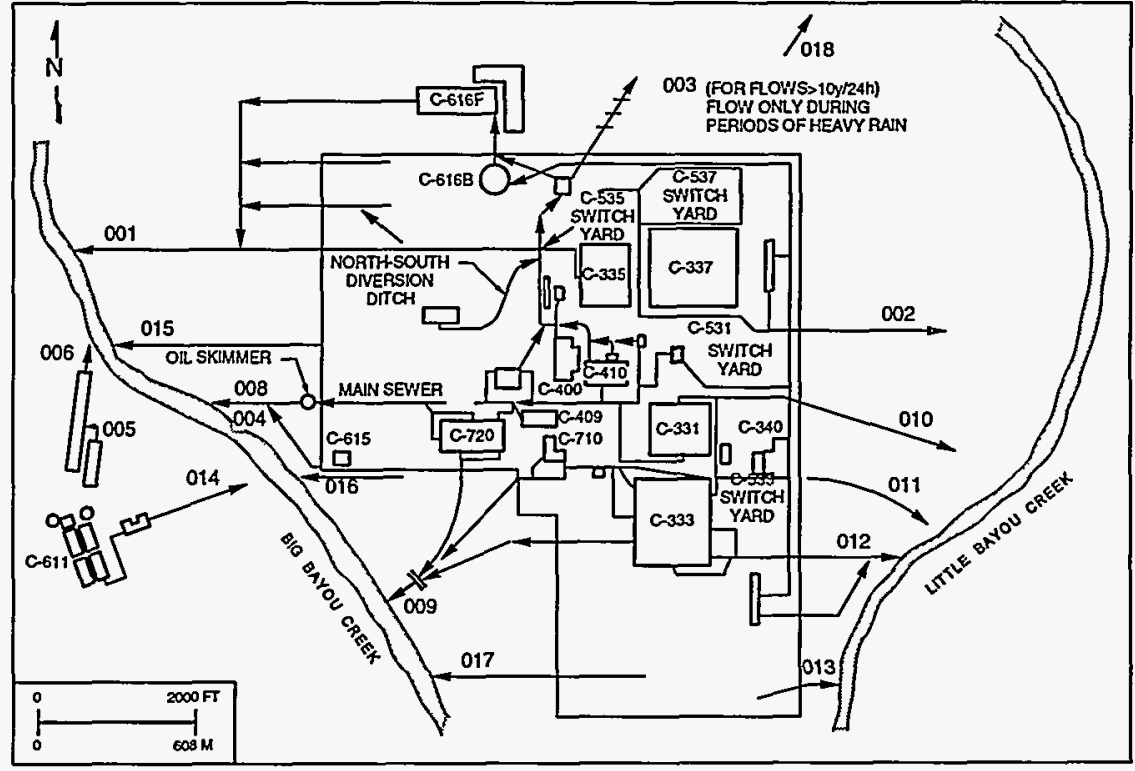

Figure 4.1 KPDES outfall locations at the Paducah Site. Outfalls 017 and 018 are the responsibility of DOE.

\section{Applicable Regulations}

DOE Orders 5400.1 and 5400.5 and the regulatory guide define effluent monitoring requirements to provide confidence that limits are not exceeded. Although no specific effluent limits for radiological parameters are included on the KPDES permit, DOE Order 5400.5 sets guidelines for allowable concentrations of radionuclides in various effluents and requires radiological monitoring to protect public health. This protection is achieved at the Paducah Site by meeting the DOE Order 5400.5 derived 
concentration guide (DCGs), which are the concentrations of given radionuclides that would result in an effective dose equivalent of $100 \mathrm{mrem} / \mathrm{year}$. The guide is based on the assumption that a member of the public has continuous, direct access to the liquid effluents and consumes 2 liters ( 0.53 gallon) of effluent every day, 365 days/year, which is a conservative exposure scenario not likely to exist. Safe drinking water limits do not apply to Paducah Site surface water sampling as effluent ditches and Big and Little Bayou Creeks are not drinking water sources for public or private use.

\section{Liquid Effluent Monitoring Program}

\section{Sample Collection Systems}

For monitoring purposes, the Paducah Site uses estimates of DCG levels to determine sampling frequencies. Effluent monitoring is based on whether the radionuclide concentrations are above or below $1 \%$ of the DCG. Although the Paducah Site monitors for other radionuclides [neptunium-237 ( ${ }^{237} \mathrm{~Np}$ ), plutonium-239 $\left({ }^{239} \mathrm{Pu}\right)$, and thorium-230 $\left.\left({ }^{230} \mathrm{Th}\right)\right]$ and screens with alpha and beta measurements, uranium and technetium-99 (99 $\mathrm{Tc}$ ) are the primary radionuclides of concern. Based on an evaluation of effluents and results reported in the Paducah Gaseous Diffusion Plant Environmental Report for 1994 (LMES 1994), which were used to prepare the Paducah Site Environmental Monitoring Plan (LMES 1995), neither continuous monitoring nor continuous sampling with frequent analyses is required because the sum of fractions of the observed concentration of each radionuclide to its corresponding DCG was much less than 1.0. However, quarterly analyses are performed at all outfall locations for ${ }^{237} \mathrm{~Np},{ }^{239} \mathrm{Pu},{ }^{230} \mathrm{Th}$, dissolved alpha, suspended alpha, dissolved beta, and suspended beta activity.

Surface runoff from the closed C-746-S residential landfill and the C-746-T inert landfill is monitored quarterly. A grab sample of the landfill runoff is monitored for uranium, gross alpha, and gross beta. The samples are taken of the landfill runoff, upstream of the runoff discharge, and downstream of the discharge at KPDES outfall 018. Sampling is performed to comply with Kentucky Division of Waste Management permit 073.14 requirements for landfill operations. In 1995 the landfills have not had final closure inspections by Kentucky Department of Waste Management (KDWM). The landfills will continue to be monitored for 30 years from the date of closure.

\section{Liquid Effluent Monitoring Results}

Tables 4.2 and 4.3 give the yearly maximum, minimum, and average concentrations of uranium and technetium, respectively, at each monitoring location. Each radionuclide is compared with the DCG and is presented as a percentage of that standard. The average concentrations at both 017 and 018 outfalls were small percentages of the corresponding DCGs for both uranium and ${ }^{99} \mathrm{Tc}$. 
Table 4.2 Uranium Concentration in DOE Outfalls for 1995

\begin{tabular}{|c|c|c|c|c|c|c|c|}
\hline \multirow[t]{2}{*}{ Outfall $^{a}$} & \multirow{2}{*}{$\begin{array}{l}\text { No. Of } \\
\text { Samples }\end{array}$} & \multicolumn{3}{|c|}{$\begin{array}{c}\text { Concentration } \\
(\mathrm{mg} / \mathrm{L})\end{array}$} & \multirow{2}{*}{$\frac{(\mathrm{pCi} / \mathrm{L})^{b}}{\mathrm{Av}}$} & \multirow{2}{*}{$\begin{array}{c}\text { wt } \% \\
{ }^{235} \mathrm{U} A v .\end{array}$} & \multirow{2}{*}{$\begin{array}{l}\text { Percentage } \\
\text { of } D C G^{c}\end{array}$} \\
\hline & & Max & Min & Av. & & & \\
\hline K017 & 1 & 0.006 & 0.002 & 0.004 & 1.8 & 0.47 & 0.31 \\
\hline K018 & 4 & 0.015 & 0.002 & 0.007 & 4.0 & 0.55 & 0.67 \\
\hline
\end{tabular}

Table 4.3 ${ }^{99} \mathrm{Tc}$ Concentration in DOE Outfalls for 1995

\begin{tabular}{|c|c|c|c|c|c|}
\hline \multirow[t]{2}{*}{ Outfall $^{a}$} & \multirow{2}{*}{$\begin{array}{l}\text { No. Of } \\
\text { Samples }\end{array}$} & \multicolumn{3}{|c|}{$\begin{array}{l}\text { Concentration } \\
(\mathrm{pCi} / \mathrm{L})^{b}\end{array}$} & \multirow{2}{*}{$\begin{array}{l}\text { Percentage } \\
\text { of } D C G^{c}\end{array}$} \\
\hline & & Max & Min & Av. & \\
\hline K017 & 4 & 22 & 0 & 8 & 0.008 \\
\hline K018 & 11 & 50 & 0 & 23 & 0.02 \\
\hline
\end{tabular}

Technetium averages for 1995 did not approach $1 \%$ of the 100,000 picocurie per liter (pCi/L) DCG. Data for 1995 do not show a significant change in relation to DCG levels for either radionuclide compared to 1994 data. The historical trends of uranium and ${ }^{99} \mathrm{Tc}$ concentrations in outfalls 017 and 018 are shown in Figures 4.2 and 4.3 .

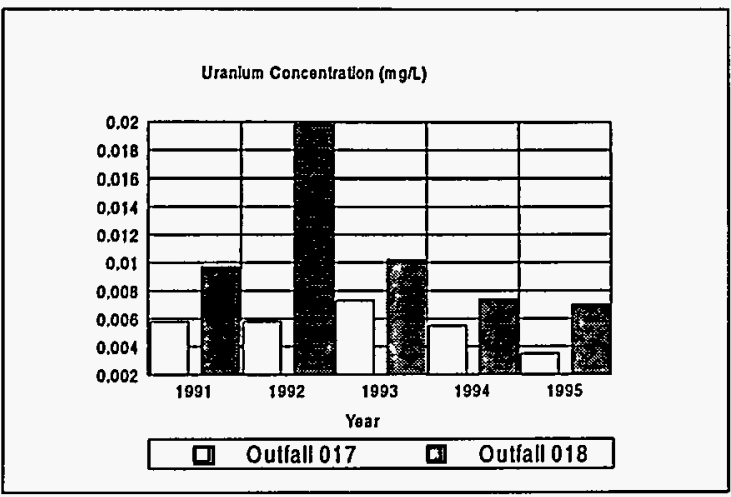

Figure 4.2 Uranium concentrations discharged to surface water, 1991 - 1995.

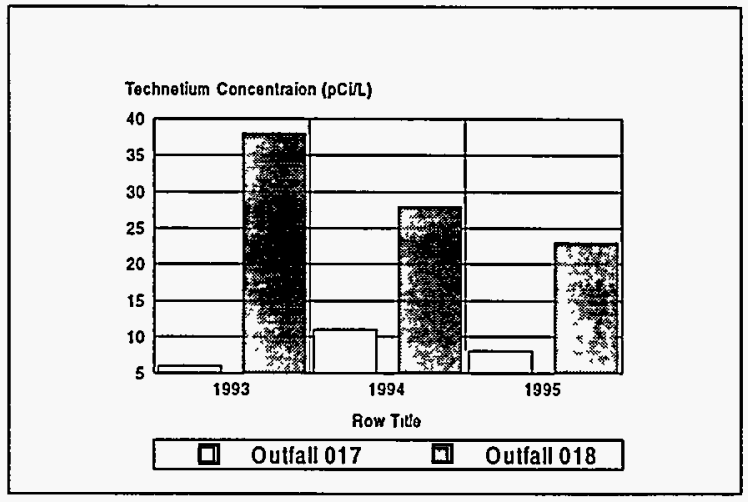

Figure 4.3 Technetium concentrations discharged to surface water, $1993-1995$. 


\title{
5. Radiological Environmental Surveillance
}

\begin{abstract}
The purpose of the radiological environmental surveillance program at the Paducah Site is to assess the effects of the Department of Energy activities on the site and the local environment and population. Surveillance includes analysis of surface water, groundwater (see Section 9), sediment, and wildlife. Surveillance results indicate that radionuclide concentrations in most sampled media were within applicable standards. Direct radiation is also measured (see Section 6), and results indicate that gamma radiation levels at and beyond the plant perimeter have not increased significantly over time.
\end{abstract}

\section{Introduction}

The radiological environmental surveillance program at the Paducah Site is based on Department of Energy (DOE) Orders 5400.1, General Environmental Protection Program, and 5400.5, Radiation Protection of the Public and the Environment, which require that an environmental surveillance program be established at all DOE sites to monitor the effects, if any, of DOE activities on the surrounding population and environment. Surveillance includes analyses of air, groundwater (see Section 9), sediment, and terrestrial wildlife.

As a result of the formation of United States Enrichment Corporation (USEC), DOE leased the operating sections of the Paducah Gaseous Diffusion Plant (PGDP) to USEC. DOE retained responsibility for locations where historic contamination might exist and liability for any existing contamination or problems. Per the lease, USEC is responsible for the existing radionuclide point-source discharges. A small number of fugitive emission sources, such as roads and scrap metal piles, that may act as fugitive radionuclide air emission sources were retained by DOE.

\section{Ambient Air}

DOE facilities do not have sufficient radioactive emissions to warrant an ambient air surveillance system although USEC maintains and operates an ambient air monitoring system to assess the impact of radioactive particulates emitted from the plant site on the surrounding environment and population.

\section{Meteorological Monitoring}

DOE Order 5400.1 requires that DOE facilities collect representative meteorological data in support of environmental monitoring activities. This information is essential to characterize atmospheric transport and diffusion conditions in the vicinity of the Paducah Site and to represent other meteorological conditions (e.g., precipitation, temperature, and atmospheric moisture) that are important to environmental surveillance activities such as air quality and radiation monitoring.

On-site meteorological data are used to calculate radiation doses to the public (see Section 6). Data from Barkley Regional Airport are used by some groups. For example, the Environmental Restoration Program uses this data to correlate precipitation with groundwater flow. 
A 60-meter tower, located south of the $\mathrm{C}-100$ administration building, contains instrumentation at heights of 10 and $60 \mathrm{~m}$. Appropriate meteorological parameters such as wind speed and direction, temperature, barometric pressure, relative humidity, and rainfall are monitored to provide valuable data on atmospheric stability as well as other data essential to reliable atmospheric dispersion modeling. Figure 5.1 shows the wind rose generated by the 1989 through 1993 data.

Computer-aided atmospheric dispersion modeling uses emission and meteorological data to determine the impacts of plant operations. Modeling is used to simulate the transport of air contaminants and to predict the effects of abnormal airborne emissions from a given source. In addition, a multitude of emergency scenarios can be developed to estimate the effects of unplanned releases on employees and population centers downwind of the source. The Areal Locations of Hazardous Atmospheres computer program is used to predict off-site concentrations of unplanned heavy-gas releases.

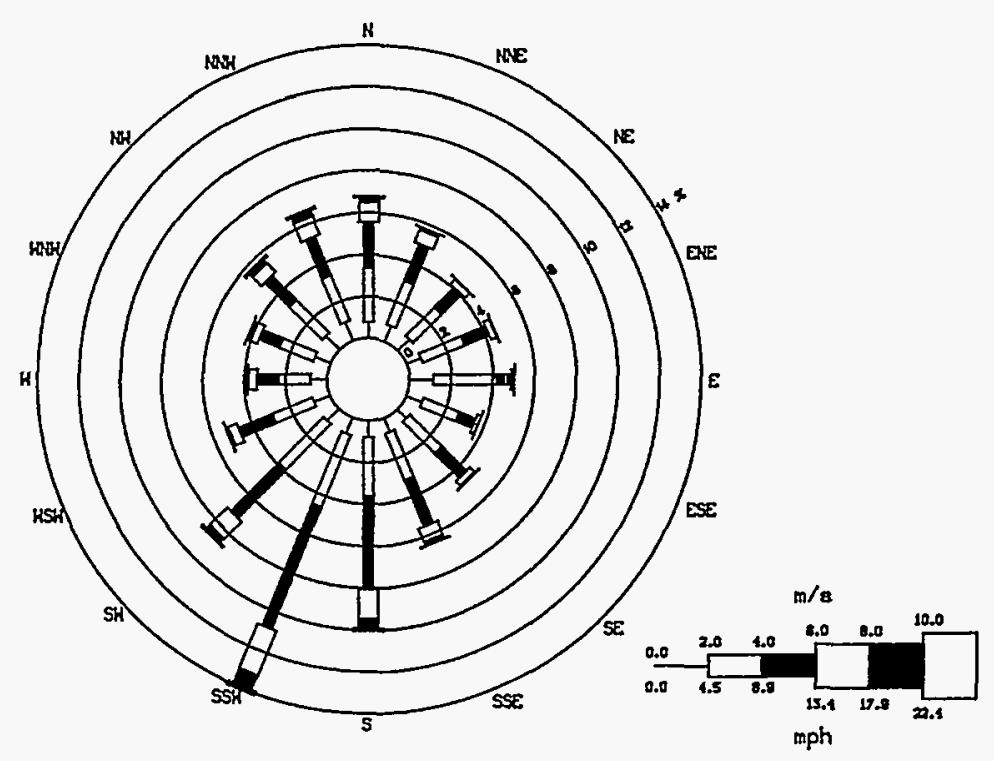

Figure 5.1 Wind Rose (60-m level) showing the wind speed frequency distribution data for 1989 to 1993

\section{Surface Water}

All Paducah Site effluents are released either to the west to Big Bayou Creek or to the east to Little Bayou Creek. The net impact of the Paducah Site on surface waters can be evaluated by comparing data from samples collected upstream of the site with sample information collected downstream of the site. Water from Big and Little Bayou Creeks are designated for all uses by the Commonwealth of Kentucky and are considered blue line streams. Discharges of effluents other than radioactive effluents from the site are controlled under KPDES. Radioactive effluents are controlled via DOE Order 5400.5.

Monthly sampling is conducted at upstream Big Bayou Creek (SW1), downstream Big Bayou Creek (SW10), upstream Ohio River (SW29), and downstream Ohio River (SW30). Background water quality is sampled at Big Bayou location SW1. Figure 5.2 depicts sampling locations. Table 5.1 shows all analyses and frequencies for radiological surveillance. 


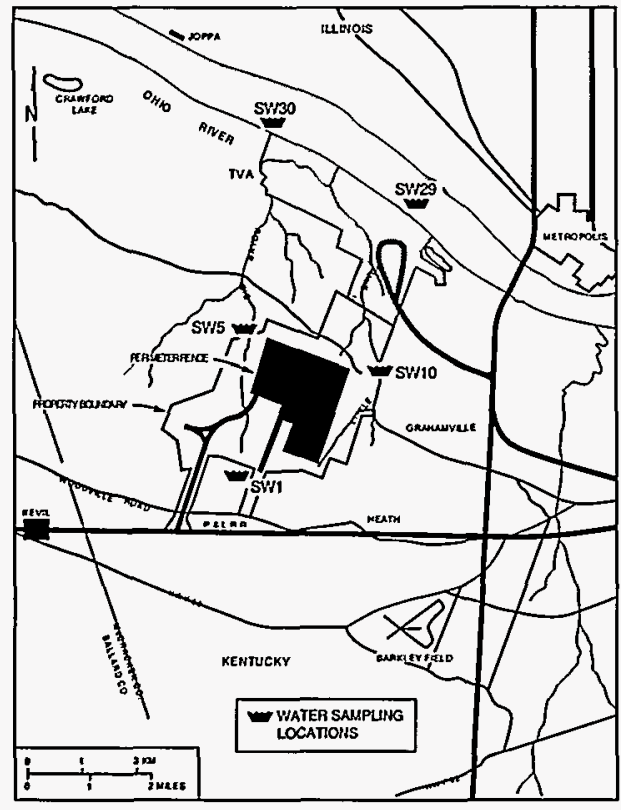

Figure 5.2 Surface water monitoring locations at the Paducah Site
Table 5.1 Sampling parameters and collection and analysis frequencies of surface water at the Paducah Site for 1995

\begin{tabular}{lllll}
\hline Station $^{0}$ & Parameter & $\begin{array}{l}\text { Collection } \\
\text { Frequency }\end{array}$ & $\begin{array}{l}\text { Sample } \\
\text { Type }\end{array}$ & $\begin{array}{l}\text { Analysis } \\
\text { Frequency }\end{array}$ \\
\hline $\begin{array}{l}\text { SW1, } \\
\text { SW5, }\end{array}$ & $\begin{array}{l}\text { Dissolved alpha and } \\
\text { beta, suspended alpha } \\
\text { and beta, }{ }^{237} \mathrm{~Np},{ }^{239} \mathrm{Pu},\end{array}$ & Monthly & Grab & Monthly \\
SW10 & & & \\
\hline${ }^{99} \mathrm{Tc}, \mathrm{U}, \%^{235} \mathrm{U}$ & & & \\
SW29, & $\begin{array}{l}\text { Gross alpha and beta, } \\
\text { SW30 }\end{array}$ & Monthly & Grab & Monthly \\
& ${ }^{237} \mathrm{~Np},{ }^{239} \mathrm{Pu},{ }^{99} \mathrm{Tc}, \mathrm{U}$, & & & \\
\hline
\end{tabular}

\section{Surface Water Surveillance Results}

Table 5.2 reflects the average concentration of radionuclides present upstream and downstream of plant effluents in Big Bayou Creek and downstream of plant effluents in Little Bayou Creek. Comparisons can be made to determine the influence of plant effluents. Little Bayou Creek upstream of plant effluents has insufficient flow to take samples most of the year. Little Bayou Creek monitoring results should be compared to upstream Big Bayou monitoring results. Big and Little Bayou combine north of the site and discharge into the Ohio River. Monitoring results in Table 5.2 also show average Ohio River radionuclide concentrations upstream of the confluence with Bayou Creeks and downstream of the confluence. Upstream and downstream results can be compared to look at the effect of site discharges on the Ohio River.

Table 5.2 Radiological Surface Water Surveillance Results

\begin{tabular}{|l|l|l|l|l|l|}
\hline Analysis & $\begin{array}{l}\text { SW10 Down } \\
\text { Stream Little } \\
\text { Bayou }\end{array}$ & $\begin{array}{l}\text { SW1 Upstream } \\
\text { Big Bayou }\end{array}$ & $\begin{array}{l}\text { SW5 } \\
\text { Downstream Big } \\
\text { Bayou }\end{array}$ & $\begin{array}{l}\text { SW29 Upstream } \\
\text { Ohio River }\end{array}$ & $\begin{array}{l}\text { SW30 } \\
\text { Downstream Ohio } \\
\text { River }\end{array}$ \\
\hline Uranium (mg/L) & 0.0118 & 0.0015 & 0.0041 & 0.001 & 0.0011 \\
\hline${ }^{99} \mathrm{Tc}(\mathrm{pCi} / \mathrm{L})$ & 9.3846 & 8.2941 & 11.438 & 7.6923 & 5.25 \\
\hline${ }^{237} \mathrm{~Np} \mathrm{(pCi/L)}$ & 0.2667 & 0.1467 & 0.0438 & 0.0769 & 0.3111 \\
\hline${ }^{239} \mathrm{Pu} \mathrm{(pCi/L)}$ & 0.0559 & 0.0759 & 0.0559 & 0.0613 & 0.0591 \\
\hline${ }^{230} \mathrm{Th}(\mathrm{pCi} / \mathrm{L})$ & 0.1025 & 0.065 & 0.08 & 0.0567 & 0.100 \\
\hline
\end{tabular}


Comparison of upstream in Big Bayou with downstream Big and Little Bayou Creek shows a net increase in most radionuclides as might be expected. Concentrations over background are insignificant. When comparing upstream and downstream samples in the Ohio River, an increase in thorium-230 and neptunium-237 is seen. Concentrations although greater than background, are not significant.

\section{Sediment}

Sediment is an important constituent of the aquatic environment. If a pollutant is a suspended solid or is attached to suspended sediment, it can settle to the bottom (thus creating the need for sediment sampling), be filtered by certain organisms, or become attached to plant surfaces. Pollutants in solution can adsorb on suspended organic and inorganic solids or be assimilated by plants and animals. The suspended solids, dead biota, or excreta settle to the bottom and become part of the organic substrata that support the bottom-dwelling community of organisms. Figure 5.3 shows possible exposure routes of trace metals (including uranium) in an aquatic ecosystem (Jinks and Eisenbud 1972).

Sediments play a significant role in aquatic ecology by serving as a repository for radioactive or chemical substances that pass via bottom-feeding biota to the higher

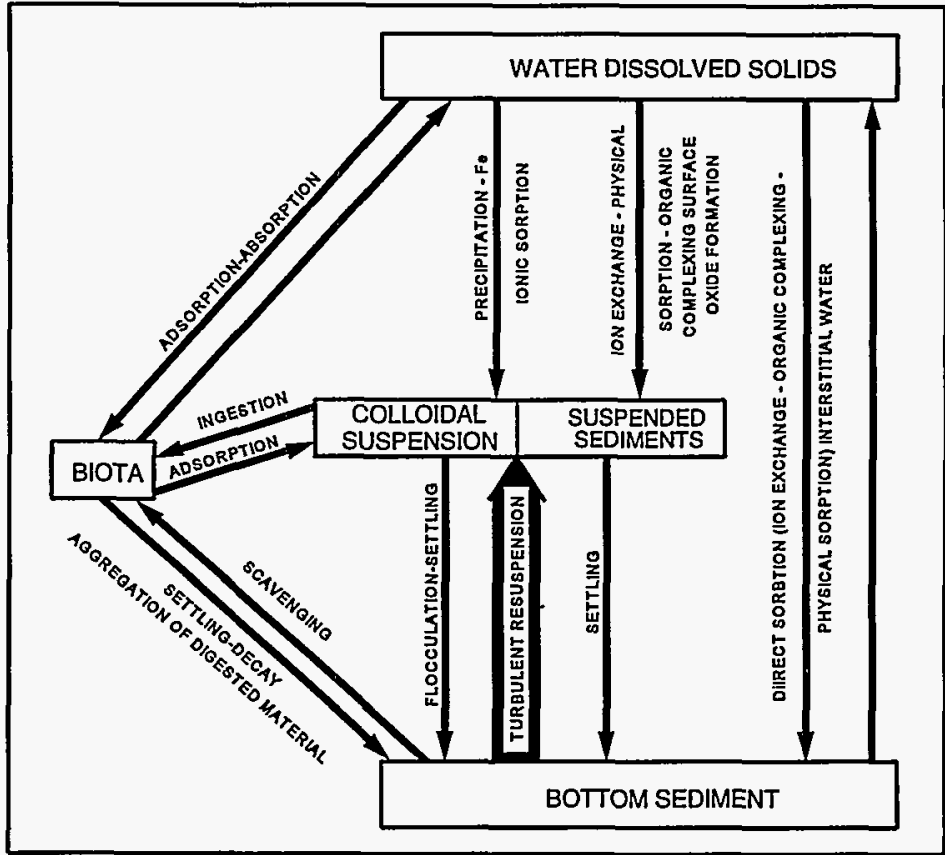

Figure 5.3 Routes of trace metals in an aquatic ecosystem. Source: S.M. Jinks and M. Eisenbud, 1972, "Concentration factors in Aquatic Environment' Radia. Data Rep. 13, 243. trophic levels. Soluble pollutants introduced into a body of water reach the bottom sediment primarily by adsorption on suspended solids that later deposit on the bottom. The deposited remains of biota that have absorbed pollutants may also be an important source of radioactive pollutants that enter the food chain.

\section{Sediment Surveillance Program}

Because DOE retained responsibility for historic environmental issues and problems, ditch sediments are tracked through a radiological environmental surveillance program. Sediment samples were taken from six locations, see Figure 5.4. Table 5.3 lists the monitoring parameters and the collection and analysis frequencies for sediment samples. 


\section{Sediment Surveillance Results}

Table 5.4 shows the 1995 results for sediment sampling. Locations SS1, SS2, and SS27 are downstream of plant effluents and may be impacted by discharges. Locations SS20, SS21, and SS28 are considered reference, or background, sites to compare with downstream data. SS20 and SS21 are on the same creeks upstream of the impacted areas, whereas SS28 is a similar stream providing a regional reference site. The downstream
Table 5.3 Sampling parameters and collection and analysis frequencies of sediment at the Paducah Site for 1995

\begin{tabular}{lllll}
\hline Station & Parameter & $\begin{array}{l}\text { Collection } \\
\text { Frequency }\end{array}$ & $\begin{array}{l}\text { Sample } \\
\text { Type }\end{array}$ & $\begin{array}{l}\text { Analysis } \\
\text { Frequency }\end{array}$ \\
\hline SS1, SS2, & ${ }^{137} \mathrm{Cs},{ }^{40} \mathrm{~K}$, & Annually & Grab & Annually \\
SS20, & ${ }^{237} \mathrm{~Np},{ }^{239} \mathrm{Pu}$, & & & \\
SS21, & ${ }^{99} \mathrm{Tc},{ }^{230} \mathrm{Th}, \mathrm{U}$, & & \\
SS27, & ${ }^{235} \mathrm{U}$ & & \\
SS28, & & & \\
\hline
\end{tabular}
radionuclide increase, is attributed to plant operations. This is verified by the assay values that are lower than natural uranium. These results concur with past studies in which uranium was detected, resulting in fencing and posting Little Bayou Creek to make the public aware that prolonged exposure could result in an increase in potential dose. Table 5.5 shows that uranium concentration in sediment has trended downward over the past 5 years.

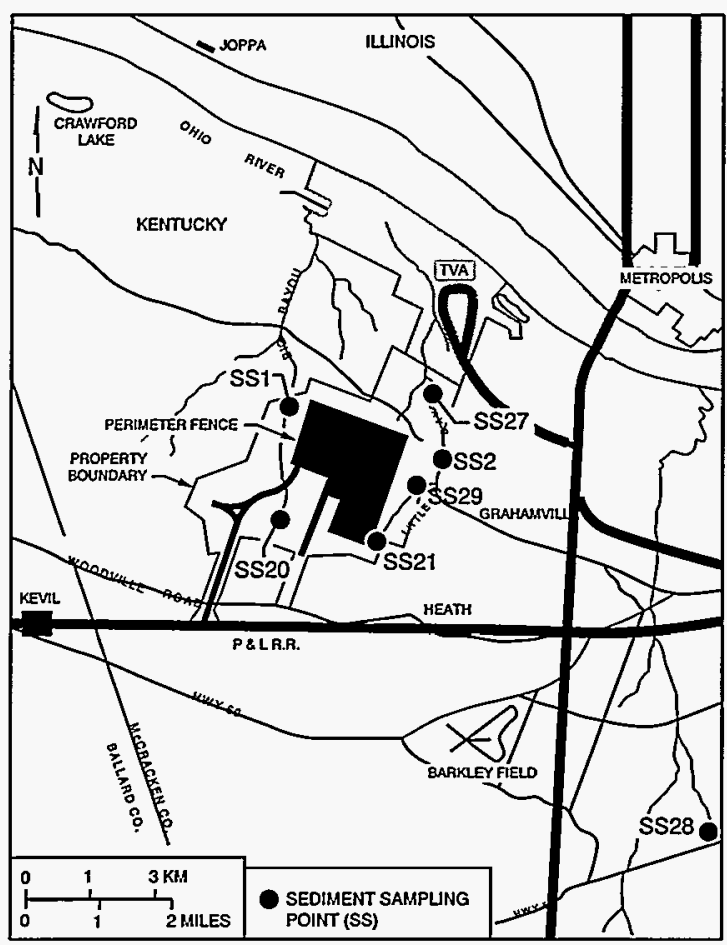

Figure 5.4 Sediment sampling locations at the Paducah Site. 
Table 5.4 Radionuclide sediment sampling results at the Paducah Site for 1995

\begin{tabular}{|c|c|c|c|c|c|c|c|c|c|}
\hline & \multirow{2}{*}{ Location } & \multicolumn{8}{|c|}{ Parameter } \\
\hline & & $\begin{array}{c}{ }^{99} \mathrm{Tc} \\
(\mathrm{pCi} / \mathrm{g})^{\mathbf{b}}\end{array}$ & $\begin{array}{l}{ }^{237} \mathrm{~Np} \\
(\mathrm{pCi} / \mathrm{g})\end{array}$ & $\begin{array}{l}{ }^{239} \mathrm{Pu} \\
(\mathrm{pCi} / \mathrm{g})\end{array}$ & $\begin{array}{c}{ }^{230} \mathrm{Th} \\
(\mathrm{pCi} / \mathrm{g})\end{array}$ & $\begin{array}{c}{ }^{137} \mathrm{Cs} \\
(\mathrm{pCi} / \mathrm{g})\end{array}$ & $\begin{array}{c}{ }^{40} \mathrm{~K} \\
(\mathrm{pCi} / \mathrm{g})\end{array}$ & ${ }_{\%}^{235} \mathrm{U}$ & $\begin{array}{l}\text { Uranium } \\
(\mu \mathrm{g} / \mathrm{g})\end{array}$ \\
\hline & \multicolumn{9}{|c|}{ Reference } \\
\hline & SS20 & 0.516 & $N^{a}$ & 0.004 & 0.155 & 0.035 & 3.1 & 0.702 & 0.9 \\
\hline & SS21 & 0.503 & ND & 0.012 & 0.274 & 0.156 & 11.3 & 0.705 & 2.25 \\
\hline & SS28 & 0.624 & ND & 0.006 & 0.053 & ND & 1.3 & 0.714 & 0.51 \\
\hline & \multicolumn{9}{|c|}{$\begin{array}{c}\text { Downstream Locations } \\
\text { Big Bayou }\end{array}$} \\
\hline & SS1 & 0.795 & ND & 0.020 & 0.153 & 0.043 & 0.9 & 0.641 & 2.97 \\
\hline & \multicolumn{9}{|c|}{ Little Bayou } \\
\hline & SS2 & 0.495 & ND & 0.007 & 0.355 & ND & 3.5 & 0.264 & 12.5 \\
\hline & SS27 & 0.560 & 0.029 & 0.170 & 2.075 & 0.041 & 1.5 & 0.287 & 8.59 \\
\hline & SS29 & 0.528 & ND & 0.005 & 0.266 & ND & 5.5 & 0.248 & 13.1 \\
\hline
\end{tabular}

${ }^{\mathrm{a}} \mathrm{ND}=$ Not Detected

\section{Terrestrial Wildlife}

In 1995, a total of 9 deer were harvested in the West Kentucky Wildlife Management Area to monitor the effects of the Paducah Site on the ecology of the surrounding area. Three deer obtained as background samples from Fort Campbell, Kentucky, were used for reference. Liver and muscle samples were analyzed for radionuclides. In addition, bone and thyroid samples were analyzed for the radionuclides strontium-90 $\left({ }^{90} \mathrm{Sr}\right)$ and technetium-99 $\left({ }^{99} \mathrm{Tc}\right)$, respectively. Because the liver and muscle tissue are considered consumable by hunters, these tissues are evaluated for radiological risks if analyses reveal detectable levels above background, or reference, deer. Bone and thyroid samples are used only as indicators of contamination. The results for all detected analytes in liver and muscle samples are summarized in Tables 5.6 and 5.7, respectively.
Table 5.5 Five year Uranium concentrations in sediment

$$
\text { Uranium }(\mu \mathrm{g} / \mathrm{g})
$$

\begin{tabular}{cccccc} 
Location $^{a}$ & 1991 & 1992 & 1993 & 1994 & 1995 \\
\hline \multicolumn{5}{c}{ Reference } \\
SS20 & 1.6 & 1.3 & 1.8 & 1.42 & 0.9 \\
\hline SS21 & 4.9 & 2.8 & 2.9 & 2.93 & 2.2 \\
\hline SS28 & 0.9 & 0.65 & 1.4 & 0.51 \\
\multicolumn{5}{c}{ Downstream Locations }
\end{tabular}

Big Bayou

\begin{tabular}{cccccc} 
SS1 & 3.2 & 4.6 & 10.5 & 14.62 & 2.97 \\
SS2 & 35.8 & 107 & 200 & 22.45 & 12.5 \\
\hline SS27 & & 11.6 & 9.4 & 10.8 & 8.6 \\
\hline
\end{tabular}

${ }^{a}$ See Figure 5.4 
Most radionuclide results that were statistically different from zero in edible portions of deer tissue were for uranium isotopes. Uranium-234 $\left({ }^{234} \mathrm{U}\right.$ ) (a radionuclide seen during all sampling events since 1990) results for both liver and muscle were equivalent compared with background deer. One of 9 liver samples and 2 of 9 muscle tissue (including one background) showed detectable ${ }^{234} U$. The concentration of radionuclides found in muscle and liver tissue of deer near the Paducah Site were not found to be appreciably different than the concentration in the background deer. Doses calculated in Table 5.6 show negligible doses associated with eating deer from near the Paducah Site.

In addition, one background deer had small concentrations of uranium- $234\left({ }^{234} \mathrm{U}\right)$, uranium- 235 $\left({ }^{235} \mathrm{U}\right)$, and uranium-238 $\left({ }^{238} \mathrm{U}\right)$; while another background deer had neptunium-237 $\left({ }^{237} \mathrm{~Np}\right)$. The small concentrations are not considered significant since they contribute little to an individuals annual environmental dose. Doses associated with eating deer from near the Paducah Site are presented in Section 6, "Dose."
Table 5.6 Paducah Site annual deer harvest for 1995, analysis of liver tissue for radionuclides

\begin{tabular}{|c|c|c|c|c|c|c|}
\hline \multirow[t]{2}{*}{ Deer } & \multicolumn{6}{|c|}{$\begin{array}{l}\text { Radionuclide } \\
\qquad(\mathrm{pCi} / \mathrm{g})^{a}\end{array}$} \\
\hline & ${ }^{234} \mathrm{U}$ & ${ }^{235} \mathrm{U}$ & ${ }^{238} \mathrm{U}$ & ${ }^{239} \mathrm{Pu}$ & ${ }^{237} \mathrm{~Np}$ & ${ }^{99} \mathrm{Tc}$ \\
\hline 1 & ND & ND & ND & ND & ND & ND \\
\hline 2 & ND & ND & ND & ND & ND & ND \\
\hline 3 & 0.005 & ND & ND & ND & ND & ND \\
\hline 4 & $\mathrm{ND}$ & ND & $\mathrm{ND}$ & ND & ND & ND \\
\hline 5 & ND & ND & ND & ND & ND & ND \\
\hline 6 & ND & ND & ND & ND & ND & ND \\
\hline 7 & ND & ND & ND & ND & ND & $\mathrm{ND}$ \\
\hline 8 & ND & ND & ND & ND & ND & ND \\
\hline 9 & ND & ND & ND & ND & ND & ND \\
\hline \multicolumn{7}{|c|}{ Background Deer } \\
\hline 10 & ND & ND & ND & ND & ND & ND \\
\hline 11 & ND & ND & $\mathrm{ND}$ & ND & ND & ND \\
\hline 12 & ND & ND & ND & ND & ND & ND \\
\hline
\end{tabular}


Table 5.7 Paducah Site annual deer harvest for 1995 - analysis of muscle tissue for radionuclides

\begin{tabular}{|c|c|c|c|c|c|c|c|c|}
\hline \multirow[t]{2}{*}{ Deer } & \multirow[b]{2}{*}{$\begin{array}{l}\text { Sample } \\
\text { Id - } 95\end{array}$} & \multicolumn{6}{|c|}{$\begin{array}{l}\text { Radionuclide } \\
\qquad(\mathrm{pCi} / \mathrm{g})^{a}\end{array}$} & \multirow[b]{2}{*}{$\begin{array}{l}\text { Dose } \\
\text { mrem }\end{array}$} \\
\hline & & ${ }^{234} U$ & ${ }^{235} \mathrm{U}$ & ${ }^{238} U$ & ${ }^{239} \mathrm{Pu}$ & ${ }^{237} \mathrm{~Np}$ & ${ }^{99} \mathrm{Tc}$ & \\
\hline 1 & 1407 & ND & ND & ND & ND & ND & ND & 0.0016 \\
\hline 2 & 1408 & $\mathrm{ND}$ & ND & ND . & ND & ND & ND & 0.0041 \\
\hline 3 & 1409 & ND & ND & ND & ND & ND & ND & 0.0027 \\
\hline 4 & 1410 & ND & ND & 0.005 & ND & ND & ND & 0.0013 \\
\hline 5 & 1411 & ND & ND & ND & ND & ND & ND & 0.0014 \\
\hline 6 & 1412 & ND & $\mathrm{ND}$ & ND & ND & $\mathrm{ND}$ & ND & 0.0009 \\
\hline 7 & 1413 & 0.014 & ND & ND & ND & ND & ND & 0.0025 \\
\hline 8 & 1414 & 0.006 & ND & ND & ND & ND & ND & 0.0015 \\
\hline \multirow[t]{2}{*}{9} & 1415 & ND & ND & ND & ND & ND & ND & 0.0028 \\
\hline & \multicolumn{5}{|c|}{ Background Deer } & & & \\
\hline 10 & 1541 & 0.12 & 0.024 & 0.065 & ND & ND & ND & 0.0064 \\
\hline 11 & 1542 & ND & ND & ND & ND & 0.2 & ND & 0.0030 \\
\hline 12 & 1543 & ND & ND & ND & ND & ND & ND & 0.0040 \\
\hline
\end{tabular}

${ }^{a} 1 \mathrm{pCi} / \mathrm{g}=0.037 \mathrm{~Bq} / \mathrm{g}$

$\mathrm{ND}=$ Not Detected 


\title{
6. Dose
}

\begin{abstract}
Most of the radioactive materials released from Department of Energy (DOE) operations at the Paducah Site are released in such low concentrations in the environment that standard monitoring procedures cannot detect them. Therefore, radiation doses to off-site populations are calculated with mathematical models. For 1995, the highest estimated dose a maximally exposed individual could have received from all combined DOE exposure pathways was 1.08 millirem (mrem). This dose is a small fraction of the applicable federal dose standard of $100 \mathrm{mrem} / \mathrm{year}$.
\end{abstract}

\section{Introduction}

This section presents the estimated doses to individuals and the surrounding population from atmospheric and liquid releases from the Paducah Site. In addition, potential doses from special case exposure scenarios, such as deer meat consumption, are estimated.

Department of Energy (DOE) Order 5400.5, Radiation Protection of the Public and the Environment, limits the dose to members of the public to less than $100 \mathrm{mrem} /$ year total effective dose equivalent from all pathways resulting from operation of a DOE facility. Information on the demography and land use of the area surrounding the plant and identification of on-site sources have indicated certain radionuclides and exposure pathways by which people can be exposed to radiation. Figures 6.1 and 6.2 give a comprehensive view of the possible pathways between radioactive materials released to the environment and human beings. In practice, only a few pathways are the major sources of exposure in any given situation.

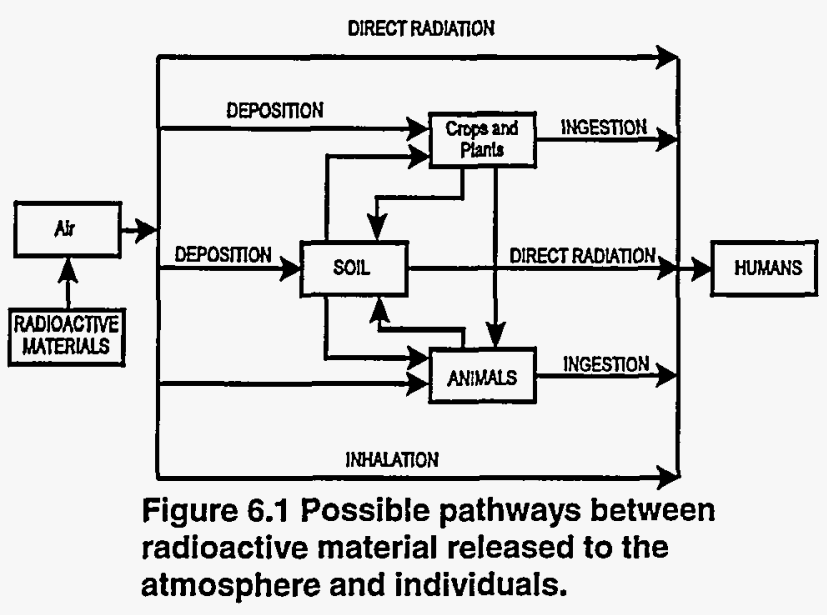

Dose

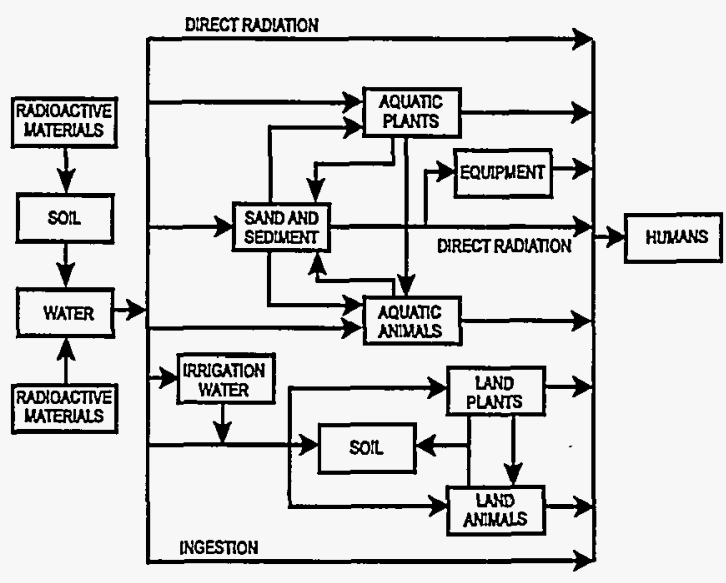

Figure 6.2 Possible pathways between radioactive materials released to surface water and individuals. 
For the Phase I Remedial Action Site Investigation, CH2M Hill conducted a preliminary assessment of risk from contaminants from the Paducah Site to the health of the public (CH2M Hill 1990). This study identified four primary pathways that each could contribute greater than $1 \%$ to the total off-site dose: groundwater ingestion, sediment ingestion, wildlife ingestion, and exposure to direct radiation. To fully assess the potential dose to the public, a hypothetical group of extreme characteristics is used to postulate an upper limit to the dose of any real group. All dose estimates were rounded to approximate significant figures.

\section{Terminology/Internal Dose Factors}

Most consequences associated with radionuclides released to the environment are caused by interactions between human tissue and various types of radiation emitted by the radionuclides. These interactions involve the transfer of energy from radiation to tissue, possibly resulting in tissue damage. Radiation may come from radionuclides outside the body (in or on environmental media or objects) or from radionuclides deposited inside the body (by inhalation, ingestion, and, in a few cases, absorption through the skin). Exposures to radiation from radionuclides outside the body are called external exposures; exposures to radiation from radionuclides inside the body are called internal exposures. This distinction is important because external exposure occurs only as long as a person is near the external radionuclide; simply leaving the area of the source will stop the exposure. Internal exposure continues as long as the radionuclide remains inside the body.

A number of specialized units have been defined for characterizing exposures to radiation as defined in Appendix A. Because the damage associated with such exposures results primarily from the deposition of radiant energy in tissue, the units are defined in terms of the amount of incident radiant energy absorbed by tissue and of the biological consequences of that absorbed energy. These units include the following:

- Committed effective dose equivalent-the total internal dose (measured in millirem) received over a 50-year period resulting from the intake of radionuclides in a 1-year period. The committed effective dose equivalent is the product of the annual intake (picocuries) and the dose conversion factor for each radionuclide (millirems per picocurie).

- Effective dose equivalent - includes the committed effective dose equivalent from internal deposition of radionuclides and the dose from penetrating radiation from sources external to the body. This is a risk-equivalent value and can be used to estimate the health-effects risk to the exposed individual.

- Total effective dose equivalent-the sum of the effective dose equivalent (for external exposures) and the committed effective dose equivalent (for internal exposures). For purposes of compliance, dose equivalent to the whole body may be used as the effective dose equivalent for external exposures.

- Collective effective dose equivalent-a measure in person-rems of long-term radiation effects over a wide area. This measure is calculated by multiplying the average dose within defined areas by the number of persons living in that area. 
Table 6.1 shows internal dose factors for several radionuclides of interest at the Paducah Site. These factors are used to determine the committed effective dose equivalent to an adult.

\section{Direct Radiation}

The exposure pathway for direct radiation, external gamma radiation, was evaluated using the results of a 1991 thermoluminescent dosimeter survey covering the banks of Little Bayou Creek. The banks were determined to have radioactive contamination above natural background levels. The calculated dose values are the product of the exposure rate (milliroentgens per hour) from the radiological survey and the exposure time at a particular location.

To determine a somewhat realistic exposure time for the Little Bayou Creek area, several assumptions were used. During 1995, the West Kentucky Wildlife Management Area allowed hunting and dog trials in this area from January 1 to March 31 and from September 1 to December 31 (213 days). For exposure in the creeks, an individual was assumed to hunt every other day during this period and spend 30 minutes in the Little Bayou Creek bed. This exposure time is probably exaggerated because most areas are fenced and signs are posted in this area stating that prolonged exposure could result in a dose above background. Also, observations by Kentucky Department of Fish and Wildlife personnel indicate that hunters spend very little time in creeks near the Paducah Site. The highest exposure rate occurs in Kentucky Pollutant Discharge Elimination System (KPDES) outfall 011 (which is fenced and posted before discharging into Little Bayou Creek). If this highest exposure rate is assumed for the above exposure times, then a dose can be calculated. Even using these extreme assumptions, the dose above background to this maximally exposed individual would be 1 millirem per year (mrem/year). This is less than the guideline value of $10 \mathrm{mrem} / \mathrm{year}$ maximum exposure from any one pathway.

\section{Contaminated Sediment in Little Bayou Creek}

Exposure to contaminated sediment in Little Bayou Creek could occur during fishing, hunting, or other recreational activities. Contact and exposure could occur primarily through incidental ingestion of 
contaminated sediment or inhalation of contaminated particles. The estimated worst-case dose above background that would be received by an individual who was assumed to spend time in the West Kentucky Wildlife Management Area every other day during the hunting season would be $0.07 \mathrm{mrem} / \mathrm{year}$.

Table 6.2 shows the dose calculation for ingestion of sediments in Little Bayou Creek. Upstream samples are assumed to be background and as subtracted from downstream sample results to arrive at a dose associated with site releases.

Table 6.2 Annual dose estimate for 1995

Worst-case incidental ingestion of sediment from Little Bayou Creek

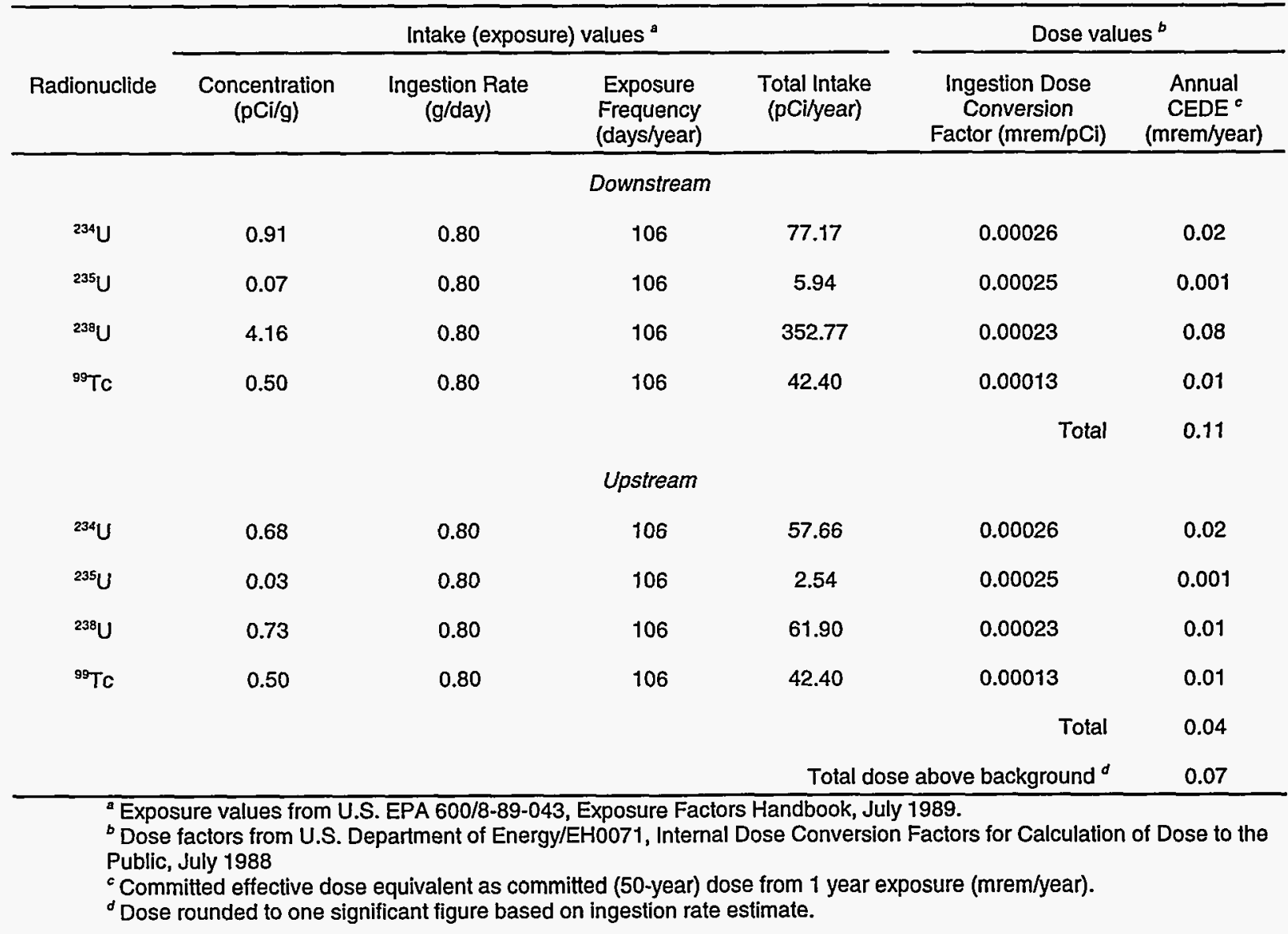

\section{Ingestion of Deer}

The effect of intake of a radionuclide by ingestion depends on the concentration of the radionuclide in food and drinking water and on the individual's consumption patterns. The estimated intake of a radionuclide is multiplied by the appropriate ingestion dose factor to provide the estimate of committed effective dose equivalent resulting from the intake. 
Terrestrial wildlife, such as deer, can come into contact with contaminated soil, ingest plants that have taken up contaminants or become coated with contaminated dust, or ingest contaminated water. Hunting is permitted in the West Kentucky Wildlife Management Area surrounding the Paducah Site, and the limit for deer harvest is two deer per person per season. The dose calculations assume that an individual kills two average-weight deer and consumes the edible portions of those deer during the year. The dose is calculated for each deer. In 1995 nine deer from the area near the Paducah Site were sampled along with three background deer. The two deer with the highest dose are compared to the average background deer and the resulting dose reported. In 1995 the average dose from the background deer was higher than the dose from the maximum two wildlifc management area deer. Because of this, the dose from ingestion of local deer is considered to be zero (concentration data is presented in Tables 5.6 and 5.7).

\section{Airborne Radionuclides}

At the Paducah Site, radioactive emissions to air are monitored to determine the extent to which the general public could be exposed and to demonstrate compliance with Environmental Protection Agency (EPA) regulations and DOE directives on radiation exposure to the public. Airborne radioactivity from DOE operations at the Paducah Site is normally too low to be detected in the presence of natural background radiation in the environment. Therefore, potential doses to the public are calculated with a dispersion model. This model calculates how measured quantities of released radionuclides mix with the atmosphere, where they travel, how they are diluted, and where they could deposit. Once the dispersion is calculated, population data and concentration/dose conversion factors are used to calculate individual and population doses. These doses include exposure from all the pathways represented in Figure 6.1, although the primary pathway of exposure is inhalation. The primary contributors to the inhalation dose are uranium-234 $\left({ }^{234} \mathrm{U}\right)$ and uranium-238 $\left({ }^{238} \mathrm{U}\right)$.

The radiation dose calculations were performed using the Clean Air Act Assessment Package-88 (CAP-88) of computer codes. This package contains the EPA's most recent version of the AIRDOS-EPA computer code. The code uses a steady-state, Gaussian plume, atmospheric dispersion model to calculate environmental concentrations of released radionuclides. The code also uses Regulatory Guide 1.109 for food-chain models to calculate human exposures, both internal and external, to radionuclides deposited in the environment. The EPA's latest version of the DARTAB computer code then uses the human exposure values to calculate radiation doses to the public from radionuclides released during the year. The dose calculations use dose conversion factors from the latest version of the RADRISK data file, which the EPA provides with CAP-88.

On August 28, 1995, DOE began operation of its only radionuclide point source at Paducah, the Northwest Treatment Facility designed to remove of trichloroethylene (TCE) and technetium $\left({ }^{99} \mathrm{Tc}\right)$ from groundwater. The facility is located at the northwest corner of the Paducah Site security area. The facility includes an air stripper to remove volatile organics from water and an ion exchange unit for the removal of ${ }^{99} \mathrm{Tc}$. The air stripper is located upstream of the ion exchange unit.

Emissions of ${ }^{99} \mathrm{Tc}$ were estimated using the analysis of the influent groundwater and the water leaving the air stripper. The ${ }^{99} \mathrm{Tc}$ concentration in the influent and effluent of the air stripper and the quantity of the 
water passing through the stripper were used to estimate the total quantity of ${ }^{99} \mathrm{Tc}$ emitted from the facility. Although the exhaust from the air stripper is passed through a carbon absorption unit prior to exhaust, no reduction in ${ }^{99} \mathrm{Tc}$ emissions due to the use of the absorption unit were assumed.

Non-point source emissions from DOE sources are minimal. Guidance from EPA which stated that provisions of Title 40, Code of Federal Regulations, Part 61, Subpart $H$, applied to fugitive and diffuse emissions, was contained in correspondence dated March 24, 1992. EPA also forwarded to the Paducah Site on September 21, 1992, questions pertaining to 1992 ambient air sampling results and their use as indications that fugitive and diffuse emissions from the Paducah Site operations were insignificant. The DOE reply satisfied all of EPA's questions except the one pertaining to resuspension of contaminated soil, which could result from such activities as well drilling activities or vehicular traffic upon contaminated earth. The question as to whether such activities actually constitute fugitive or diffuse sources was forwarded to EPA headquarters for resolution. DOE has not yet received a response to this question. It is not expected that any activity that would result in fugitive or diffuse emissions would result in emissions that would be distinguishable from background at off-site locations.

Another potential fugitive or diffuse source of radionuclides, albeit a minor one, results from the decontamination of machinery and equipment used in remediation activities such as well drilling. The equipment is washed with high-powered sprayers to remove any contaminants (radiological or nonradiological). The contaminants originate from the soil and groundwater. The concentrations of contaminants on the equipment are so small that under most circumstances contamination cannot be distinguished from background.

For calculating dose from the pilot plant, computer codes used pilot plant-specific radionuclide emission data for 1995, meteorological data collected from 1989 through 1993 at the 60-meter station at the Paducah Site, and dose conversion factors specified in the CAP- 88 codes. Organ weighing factors used in estimating effective dose equivalents are also based on International Commission on Radiological Protection recommendations (ICRP 1977).

The calculated 50-year committed effective dose equivalent (internal) from DOE air sources to the maximally exposed individual was estimated to be $0.003 \mathrm{mrem}(0.00003 \mathrm{mSv})$, which is well below the 10-mrem limit. The dose to the maximally exposed individual, who under most circumstances is the person living closest to the plant in the predominant wind direction, is calculated each year. The maximally exposed individual for 1995 is located approximately 2000 meters (6600 feet) north of the plant site.

The collective effective dose equivalent is a good measure of long-term radiation effects over a wide area. The 1995 collective effective dose equivalent for the 500,500 residents within 80 kilometers (50 miles) from DOE emissions was estimated to be 0.04 person-rem. This dose can be compared with a collective dose for the same population of 200,000 person-rem/year from natural background radiation. 


\section{Conclusions}

Table 6.3 contains a summary of the dose for 1995 from radiological contaminants that could be received by a member of the public living near the plant assuming worst-case exposure from all major pathways. The groundwater pathway from DOE sources is assumed to contribute nothing to the population or maximally exposed individuals dose because all residents have been supplied with public water by DOE. Figure 6.3 shows the potential annual dose for the past five years. The calculated maximum combined (internal and external) dose to an individual would be $1.08 \mathrm{mrem} /$ year for current and historical DOE activities. This level is well below the DOE annual dose limit of $100 \mathrm{mrem} / \mathrm{ye}$ ar to members of the public. The major contributors to the dose are direct radiation from the banks of Little Bayou Creek and ingestion of sediment in or near the Little Bayou Creek bed. The potential exposure areas of the creek have been fenced, and signs have been posted to notify the public of the elevated radiation levels.

Estimates of radiation doses presented in this report were calculated using the dose factors provided by DOE (DOE 1988). These dose factors are based on International Commission on Radiological Protection Publication 30, Limits of Intakes of Radionuclides by Workers (ICRP 1979).

Table 6.3 Summary of potential radiological dose from the Paducah Site for 1995 - Worst-case combined exposure pathways

\begin{tabular}{|c|c|c|c|}
\hline Pathway & $\begin{array}{c}\text { Dose }^{a . b} \\
\text { (Mrem/year) }\end{array}$ & $\begin{array}{l}\text { Percent } \\
\text { of total }\end{array}$ & $\begin{array}{c}\text { Maximum allowable } \\
\text { exposure, DOE } \\
\text { Order 5400.5 } \\
\text { (mrem/year) }\end{array}$ \\
\hline Ingestion of sediments & 0.07 & 6 & \\
\hline Ingestion of deer meat & 0 & 0 & \\
\hline $\begin{array}{l}\text { Direct radiation } \\
\text { (Little Bayou Creek) }\end{array}$ & 1 & 94 & \\
\hline Atmospheric releases & $<0.01$ & $<1$ & \\
\hline $\begin{array}{l}\text { Total annual dose } \\
\text { above background (all } \\
\text { pathways) }\end{array}$ & 1.08 & & 100 \\
\hline \multicolumn{4}{|c|}{$\begin{array}{l}\text { Dose values were rounded to yield the correct number of significant digits } \\
\text { based on all the } 1994 \text { data used to estimate the worst-case dose from all } \\
\text { exposure pathways and from estimated significant figures in atmospheric } \\
\text { releases per DOE/EH-0173T, Environmental Regulatory Guide for } \\
\text { Radiological Effluent Monitoring and Environmental Surveillance. } \\
\qquad b 100 \text { mrem }=1 \mathrm{mSv}\end{array}$} \\
\hline
\end{tabular}

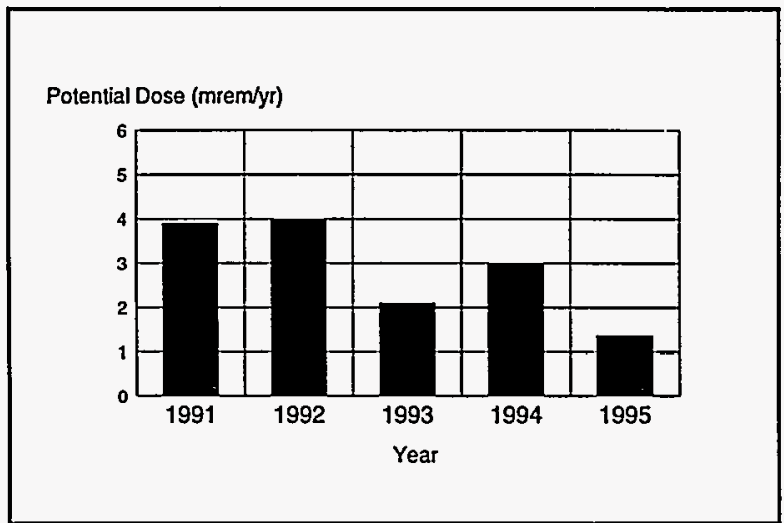

Figure 6.3 Potential radiological dose from the Paducah Site, 1991 thru 1995. 


\title{
7. Nonradiological Effluent Monitoring
}

\begin{abstract}
Effluents are gaseous or liquid waste discharges to the environment. Monitoring effluents assures compliance with applicable release standards established by federal and state regulations. Effluent monitoring consists of the collection and analysis of samples or measurements of liquid, gaseous, or airborne effluents to determine and quantify contaminants and process-stream characteristics, assess any chemical or radiological exposures to members of the public or the environment, and demonstrate compliance with applicable standards. Monitoring effluents is essential to determine the effects emissions may have on the public and the surrounding environment.
\end{abstract}

In 1995, there were no reportable Kentucky Pollutant Discharge Elimination System (KPDES) exceedences at Department of Energy (DOE) outfalls. However, seven reportable KPDES effluent exceedences (discharges exceeding the permit limits) that occurred during the year at United States Enrichment Corporation (USEC)-leased outfalls resulted in two Notice of Violations. DOE has accepted responsibility for these violations and for resolution of the problem since they are associated with historic use of polychlorinated biphenyls (PCBs) and trichloroethylene (TCE).

DOE retained no point sources for air emissions as a result of the lease agreement.

\section{Introduction}

Responsibility for nonradioactive airborne emission sources at Paducah Gaseous Diffusion Plant (PGDP) was turned over to United States Enrichment Corporation (USEC) as a result of the lease agreement between USEC and Department of Energy (DOE). Only a few fugitive sources, such as gravel roads, dirt piles (resulting from construction excavation), and metal scrap pile windage, remain the responsibility of DOE. These sources are not considered to be major.

Monitoring of nonradiological parameters in liquid effluents is documented in the Paducah Site Environmental Monitoring Plan (LMES 1995) and is further defined in the Kentucky Pollutant Discharge Elimination System (KPDES) permit, KY-0004049, and in Kentucky Department of Waste Management (KDWM) landfill permit 073.14 as well as the new landfill KPDES permit, KY-0100072. Sampling and analytical activities are the responsibility of Energy Systems, but those services are procured from Utility Services. The Environmental Monitoring Section, part of the Utility Services Environmental, Safety, and Health Division, provides sampling support. The analytical laboratory, part of the Utility Services Production Support Division, provides analytical measurements. Effluents are monitored for nonradiological parameters as listed on the permit governing the discharge.

\section{Airborne Effluents}

DOE has responsibility for four air emission sources as a result of the lease agreement with USEC. These four sources are two separate fluorescent lamp crushers, four trichloroethylene (TCE) tanks, and the northwest plume pump-and-treat system. Of the two fluorescent lamp crushers permitted, one has never been purchased and the other one was used only once. Recycling options for fluorescent lamps are being 
evaluated. The four TCE tanks located at C-733 were empty throughout 1995, and no plans exist to use the tanks. DOE had no operating point sources in 1995.

\section{Airborne Effluenť Monitoring Program}

No nonradiological emissions exist for an air monitoring program.

\section{Liquid Effluents}

\section{Liquid Effluent Applicable Regulations}

The Clean Water Act is administered for the Paducah Site by the Kentucky Department of Water (KDOW) through the KPDES Wastewater Discharge Permitting Program. The current KPDES permit became effective on November 1, 1992. This permit contains limits based on water quality criteria with a zero flow stream. The Paducah Site adjudicated portions of the permit that contained unattainable effluent limits and implemented the portions of the permit not under adjudication. The KDOW granted a stay from the adjudicated limits while an agreed order is being negotiated. The stay applies to the limits for temperature, phosphorus, pH, cadmium, chromium, copper, lead, nickel, and zinc.

\section{Liquid Effluent Monitoring Program}

Nonradiological effluent monitoring for all but two of the 18 outfalls at PGDP was placed under the jurisdiction of USEC. The two DOE-retained outfalls are monitored for KPDES parameters. DOE retained no point sources for liquid effluents as a result of the lease agreement but did retain responsibility for any historic pollutants that could result from past operations at the plant. No exceedences of permit limits occurred in 1995 at the two DOE retained outfalls. Two notices of violation were received for USEC-held outfalls as a result of historic uses of PCBs. DOE has accepted responsibility for these violations and for resolution of the problem.

Monitoring of the two DOE outfalls, 017 and 018 (see Fig. 4.1), is conducted in accordance with the KPDES permit. Title 40, Code of Federal Regulations, Part 136 (40 CFR 136), lists the specific sample collection, preservation, and analytical methods acceptable for the types of pollutants to be analyzed. Preservation in the field is conducted per 40 CFR 136, and chain-of-custody procedures are followed after collection and during transport to the analytical laboratory. The samples are then accepted by the laboratory and analyzed per 40 CFR 136 procedures for the parameters required for by the KPDES permit.

Surface runoff from the closed C-746-S residential landfill and the C-746-T inert landfill is monitored quarterly. A grab sample of the landfill runoff is monitored for chloride, sulfate, $\mathrm{pH}$, sodium, uranium, iron, total organic carbon, total suspended solids, total dissolved solids, and specific conductivity. The samples taken include landfill runoff, upstream of the runoff discharge, and downstream of the discharge at KPDES outfall 018. Sampling is performed to comply with KDWM. 


\section{Liquid Effluent Monitoring Results}

Analytical results are reported to the KDOW each month in a discharge monitoring report, which includes the status of DOE's two intermittent-flowing outfalls, a detection limit discussion, and toxicity data collected during the month (if applicable).

No exceedences of the permit limits occurred during the year at the two DOE outfalls. However, DOE accepted responsibility for historic problems associated with USEC-leased KPDES outfalls. In 1995, two notices of violation were received for PCB exceedences in liquid effluents at outfall 011 and outfall 012 , see Table 7.1. TCE exceedences were reported in outfall 011.

Table 7.1 PCB Concentration in outfalls for 1995

\begin{tabular}{|c|c|c|c|c|}
\hline \multirow{2}{*}{ Outfall $^{a}$} & \multirow{2}{*}{$\begin{array}{l}\text { No. Of } \\
\text { Samples }\end{array}$} & \multicolumn{3}{|c|}{$\begin{array}{l}\text { Concentration } \\
(\mu \mathrm{g} / \mathrm{L})\end{array}$} \\
\hline & & Max & Min & Av. \\
\hline K001 & 12 & $<0.17$ & $<0.17$ & $<0.17$ \\
\hline K002 & 12 & $<0.17$ & $<0.17$ & $<0.17$ \\
\hline K006 & 13 & $<0.17$ & $<0.17$ & $<0.17$ \\
\hline $\mathrm{K} 008$ & 13 & $<0.17$ & $<0.17$ & $<0.17$ \\
\hline K009 & 13 & $<0.17$ & $<0.17$ & $<0.17$ \\
\hline K010 & 12 & $<0.17$ & $<0.17$ & $<0.17$ \\
\hline K011 & 16 & 0.29 & $<0.17$ & $<0.17$ \\
\hline $\mathrm{K} 012$ & 16 & 0.26 & 0.10 & $<0.17$ \\
\hline K013 & 12 & $<0.17$ & $<0.17$ & $<0.17$ \\
\hline K015 & 10 & $<0.17$ & $<0.17$ & $<0.17$ \\
\hline K016 & 10 & $<0.17$ & $<0.17$ & $<0.17$ \\
\hline $\mathrm{K} 017$ & 11 & $<0.17$ & $<0.17$ & $<0.17$ \\
\hline K018 & 12 & $<0.17$ & $<0.17$ & $<0.17$ \\
\hline
\end{tabular}

${ }^{\circ}$ See Figure 4.1

"Each noncompliance for a monthly sample results in a noncompliance of the monthly average. 


\title{
8. Nonradiological Environmental Surveillance
}

\author{
Abstract \\ The purpose of the nonradiological environmental surveillance program at Paducah Site is to assess the \\ effects of the Department of Energy operations on the site and the local environment and population. \\ Surveillance includes analysis of air, surface water, groundwater (see Section 9), sediment, soil, \\ vegetation, and fish and other aquatic life. Surveillance results indicated that nonradionuclide \\ concentrations in most sampled media were within applicable standards.
}

\section{Introduction}

Nonradiological environmental surveillance at the Paducah Site involves sampling and analysis of air, surface water, groundwater (see Section 9 for groundwater surveillance results), sediment, soil, vegetation, and fish and other aquatic life.

As a result of the transfer of the production part of the plant to United States Enrichment Corporation (USEC), all air point sources and 14 of the 16 active Kentucky Pollutant Discharge Elimination System (KPDES) liquid effluent discharges were transferred to USEC.

\section{Ambient Air}

Because there are no permitted Department of Energy (DOE) air emission sources at the Paducah Site, ambient air information is not included in this report.

\section{Surface Water}

Routine surface water monitoring that is not required by the KPDES permit is performed at the Paducah Site as part of the environmental surveillance program. The net impact of Paducah Site's activities on surface waters is evaluated by comparing data from samples collected at a reference location at Massac Creek with information from samples collected upstream and downstream of the facility from Little Bayou and Big Bayou Creeks. Bimonthly surface water samples are collected at six locations with another location being selected for biannual sampling. The samples are analyzed for general water quality parameters, volatile organic compounds, and selected radionuclides and dissolved metals.

\section{Surveillance Results}

These locations are monitored to maintain data that could possibly be used to explain or trace unusual results at other locations. These data can be compared from year to year to determine if significant changes have occurred. The data can also be compared using upstream and downstream locations around the 
Paducah Site, see Tables 8.1 and 8.2. Historical comparisons between 1994 and 1995 data did not identify any unusual trends. Comparisons between upstream and downstream locations does not show any significant differences.

Locations SW 29 and SW 30, both involving the Ohio River water, are monitored to obtain information on any unusual results that could show up in KPDES discharges. Ohio River water is used in the water treatment plant to provide potable, fire, and cooling water for the PGDP. SW 29 is above where the Paducah Gaseous Diffusion Plant (PGDP) effluent discharges in to the Ohio River through Big Bayou Creek. SW 30 is below the location where Big Bayou Creek discharges into the Ohio River. Compared to 1994 data, 1995 data show elevations in chloride and sulfate, at both upstream and downstream locations.

Location SW 1 and SW5 are both located on Big Bayou Creek. Location SW 1, upstream Big Bayou Creek, is located above all DOE and USEC discharges, while SW 5 is located on Big Bayou Creek downstream of DOE and USEC liquid effluent discharges. Comparison of the data form these locations identified chloride at the downstream location being

3 times higher than the upstream site. Iron data revealed that the downstream location was 5 times lower than the upstream location. Since the chloride parameter was added during the last revision of the Environmental Monitoring Plan, data at the downstream location is only available since October. Inadequate data exists to determine what may have contributed to this situation. Data from these locations will be monitored during future sampling events and additional sampling may be required.
Table 8.1 1995 Big Bayou Creek Surveillance

\begin{tabular}{lcc}
\hline & $\begin{array}{c}\text { SW1 Upstream } \\
\text { Big Bayou }\end{array}$ & $\begin{array}{c}\text { SW5 } \\
\text { Downstream Big } \\
\text { Bayou }\end{array}$ \\
\cline { 2 - 3 } Cadmium (mg/L) & 0.001 & 0.001 \\
Chloride (mg/L) & 14.082 & 75.067 \\
Chromium (mg/L) & 0.0108 & 0.011 \\
Copper (mg/L) & 0.0116 & 0.1907 \\
Iron (mg/L) & 0.9696 & 0.1907 \\
Lead (mg/L) & 0.003 & 0.003 \\
Nickel (mg/L) & 0.05 & 0.05 \\
Phosphorus (mg/L) & 0.0667 & 0.2667 \\
Zinc (mg/L) & 0.0178 & 0.024 \\
PCB ( $\mu \mathrm{gg} / \mathrm{L})$ & 0.156 & 0.17 \\
TCE ( $\mathrm{mg} / \mathrm{L})$ & 1 & 1 \\
\hline
\end{tabular}

Table 8.2 1995 Ohio River Surveillance

\begin{tabular}{lcc}
\hline & $\begin{array}{c}\text { SW29 Upstream } \\
\text { Ohio River }\end{array}$ & $\begin{array}{c}\text { sw30 Downstream } \\
\text { Ohio River }\end{array}$ \\
Chloride (mg/L) & 11.142 & 12.1 \\
Fluoride (mg/L) & 0.1164 & 0.1222 \\
$\begin{array}{l}\text { Nitrate as Nitrogen } \\
\text { (mg/L) }\end{array}$ & 1.2273 & 1.6667 \\
Phosphate as P (mg/L) & 1.8273 & \\
Sulfate (mg/L) & 25.564 & 1.7889 \\
$\begin{array}{l}\text { Hexavalent Chromium } \\
\text { (mg/L) }\end{array}$ & 0.01 & 29.767 \\
TCE ( $\mu$ g/L) & 1 & 0.01 \\
\hline
\end{tabular}




\section{Sediment}

Stream sediments are an important constituent of the aquatic environment. If a pollutant is a suspended solid or is attached to suspended sediment, it can settle to the bottom (thus creating the need for sediment sampling), be filtered by certain organisms, or become attached to plant surfaces. Pollutants in solution can adsorb on suspended organic and inorganic solids or be assimilated by plants and animals. The suspended solids, dead biota, or excreta settle to the bottom and become part of the organic substrata that support the bottom-dwelling community of organisms. Figure 5.4 shows possible exposure routes of trace metals in an aquatic ecosystem (Jinks and Eisenbud 1972).

Sediments play a significant role in aquatic ecology by serving as a repository for chemical substances that pass via bottom-feeding biota to the higher trophic levels. Soluble pollutants introduced into a body of water reach the bottom sediment primarily by adsorption on suspended solids that later deposit on the bottom. The deposited remains of biota that have absorbed pollutants may also be an important source of chemical pollutants that enter the food chain.

\section{Sediment Surveillance Program}

Because DOE retained responsibility for historic environmental issues and problems, ditch sediments are tracked through a nonradiological environmental surveillance program, which focuses on monitoring for polychlorinated biphenyls (PCBs). Sediment samples were taken from six locations, see Figure 8.1. Table 8.3 lists the monitoring parameters and the collection and analysis frequencies for sediment samples.

\section{Sediment Surveillance Results}

PCB results at location SS2 for 1991-1995 are shown in Table 8.4. Results for this location are shown because historically this location has had the highest PCB

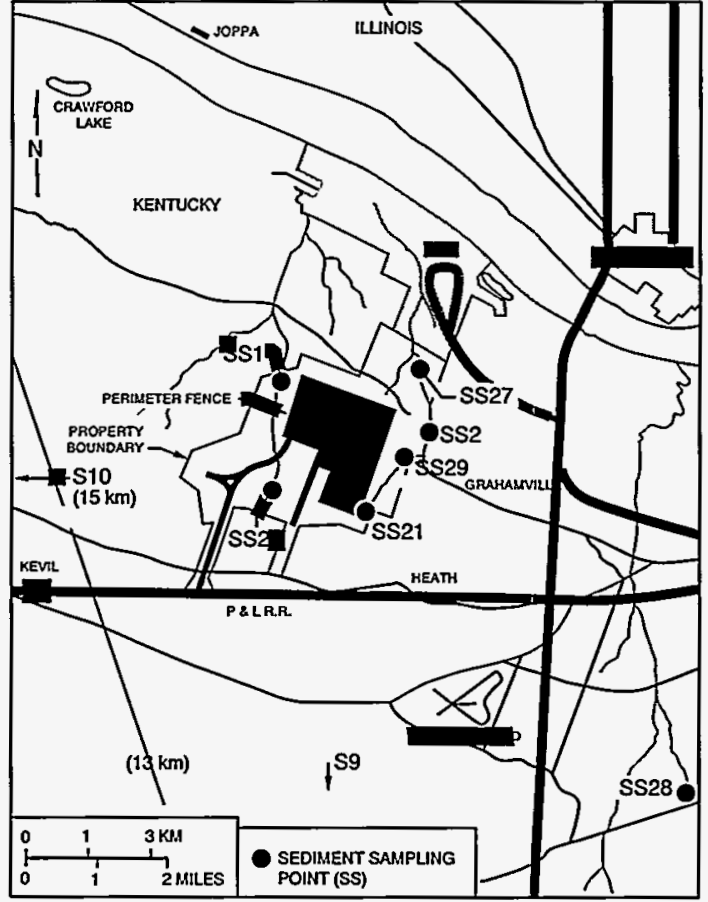

Figure 8.1 Sediment sampling locations at the Paducah Site. concentrations at the Paducah Site. Data for 1994 and 1995 confirms a trend in the reduction of PCB contamination at this site. Due to data from past studies in which PCBs were detected, signs were posted at Little Bayou Creek to make the public aware of the PCB contamination.

The sampling results for other nonradiological constituents are summarized in Table 8.5. Big and Little Bayou creeks and KPDES-permitted discharge ditches were investigated during administrative consent order activities. Remedial alternatives were drafted (SAIC 1991a) and are being reviewed by the Environmental Protection Agency (EPA) and the Kentucky Department for Environmental Protection 
(KDEP). When finalized, this document will become the record of decision under the Comprehensive Environmental Response, Compensation, and Liability Act (CERCLA) in response to the administrative consent order.

Table 8.3 Sampling parameters and collection and analysis frequencies of sediment at the Paducah Site for 1995

\begin{tabular}{|c|c|c|c|c|}
\hline Station ${ }^{a}$ & Parameter & $\begin{array}{l}\text { Collection } \\
\text { Frequency }\end{array}$ & $\begin{array}{l}\text { Sample } \\
\text { Type }\end{array}$ & $\begin{array}{l}\text { Analysis } \\
\text { Frequency }\end{array}$ \\
\hline $\begin{array}{l}\text { SS1, SS2, SS20, } \\
\text { SS21, SS27, SS28 }\end{array}$ & $\begin{array}{l}\text { PCBs, Ag, Al, As, Ba, Be, Bi, Ca, Cd, } \\
\text { Co, Cr, Cu, Fe, I, K, Li, Mg, Mn, Mo, } \\
\text { Na, Nb, Ni, P, Pb, Ru, Sb, Si, Sn, Ta, } \\
\text { Th, Ti, Tl, V, W, Zn, Zr, As }\end{array}$ & Annually & Grab & Annually \\
\hline
\end{tabular}

"See Figure 8.1

\section{Soil}

Because the major source of soil contamination is from air pathways and because DOE no longer controls any air point sources, soil surveillance is not included in this report.

Table 8.4 PCB results (in $\mu \mathrm{g} / \mathrm{g}$ ) for sediment samples from location SS2, 1991-1995

\section{Vegetation}

Because DOE no longer operates any sources of fluoride emissions, vegetation surveillance is not included in this report.

\begin{tabular}{ll}
1991 & 0.2 \\
1992 & 0.9 \\
1993 & 2.0 \\
1994 & 1.4 \\
1995 & $<0.1$ \\
\hline
\end{tabular}

\section{Fish and Other Aquatic Life}

The Biological Monitoring Program (BMP) for the Paducah Site was initiated in 1987 by the Environmental Sciences Division (ESD) at Oak Ridge National Laboratory, Oak Ridge, Tennessee. Initially, the monitoring was performed under a subcontract with the University of Kentucky, but after 1990 the monitoring was conducted by ESD staff. The objectives of BMP are to (1) demonstrate that the effluent limitations established for the Paducah Site protect and maintain the use of Little Bayou and Big Bayou creeks for growth and propagation of fish and other aquatic life, (2) characterize potential environmental impacts, (3) document the effects of pollution abatement facilities on stream biota, and (4) recommend any program improvements that would increase effluent treatability. A BMP is not required in either the Agreed Order or the KPDES permit; however, biological monitoring at the Paducah Site is required under DOE Order 5400.1. Data collected under the BMP will also be used to support two studies proposed in the Agreed Order. 
Table 8.5 Nonradiological sediment sampling results for 1995

\begin{tabular}{|c|c|c|c|c|c|c|c|c|c|c|c|c|c|c|c|}
\hline Location $^{\mathrm{a}}$ & $\begin{array}{l}\text { Barium } \\
\mathrm{mg} / \mathrm{kg}\end{array}$ & $\begin{array}{c}\text { Calcium } \\
\mathrm{mg} / \mathrm{kg}\end{array}$ & $\begin{array}{c}\text { Chromium } \\
\mathrm{mg} / \mathrm{kg}\end{array}$ & $\begin{array}{l}\text { Copper } \\
\mathrm{mg} / \mathrm{kg}\end{array}$ & $\begin{array}{c}\text { Lead } \\
\mathrm{mg} / \mathrm{kg}\end{array}$ & $\begin{array}{c}\text { Lithium } \\
\mathrm{mg} / \mathrm{kg}\end{array}$ & $\begin{array}{c}\text { Manganese } \\
\mathrm{mg} / \mathrm{kg}\end{array}$ & $\begin{array}{c}\text { Parameter } \\
\text { Molybdenum } \\
\text { mg/kg }\end{array}$ & $\begin{array}{l}\text { Potassium } \\
\mathrm{mg} / \mathrm{kg}\end{array}$ & $\begin{array}{l}\text { Silver } \\
\mathrm{mg} / \mathrm{kg}\end{array}$ & $\begin{array}{l}\text { Strontium } \\
\mathrm{mg} / \mathrm{kg}\end{array}$ & $\begin{array}{c}\text { Tin } \\
\mathrm{mg} / \mathrm{kg}\end{array}$ & $\begin{array}{l}\text { Vanadium } \\
\mathrm{mg} / \mathrm{kg}\end{array}$ & $\begin{array}{c}\mathrm{Zinc} \\
\mathrm{mg} / \mathrm{kg}\end{array}$ & $\begin{array}{c}\text { Zirconium } \\
\mathrm{mg} / \mathrm{kg}\end{array}$ \\
\hline \multicolumn{16}{|c|}{ Reference } \\
\hline SS20 & 34.4 & ND & 8.31 & 4.98 & ND & 2.54 & 301 & ND & 423 & 50.2 & 4.5 & 120 & 14.2 & ND & 4.98 \\
\hline SS21 & 82.8 & ND & 10.8 & 7.2 & ND & 6.85 & 224 & 5.5 & 158 & 76.2 & 12.5 & 106 & 20.8 & ND & 12.6 \\
\hline SS28 & 13.8 & ND & ND & ND & ND & 0.98 & 112 & ND & 213 & 24.2 & 2.6 & ND & 5.79 & 8.44 & 3.44 \\
\hline \multicolumn{16}{|c|}{ Downstream Locations } \\
\hline \multicolumn{16}{|c|}{ Big Bayou } \\
\hline SS1 & 22.4 & ND & 11.2 & 3.67 & ND & 2.48 & 167 & ND & 323 & 59.2 & 4.16 & ND & 14.8 & ND & 5.84 \\
\hline \multicolumn{16}{|c|}{ Little Bayou } \\
\hline SS2 & 39.9 & ND & 42.8 & 5.38 & 28.8 & 3.09 & 337 & ND & 475 & 160 & 14.2 & 180 & 37.3 & 11.8 & 11.2 \\
\hline SS27 & 20.6 & 1542 & 52.9 & 4.78 & ND & 2.02 & 86.9 & ND & 273 & 37.8 & 7.16 & ND & 10 & 11.7 & 4.5 \\
\hline SS29 & 61.1 & ND & 14.1 & 14.1 & ND & 6.17 & 60.2 & ND & 386 & 105 & 2.6 & ND & 21.4 & ND & 10.5 \\
\hline
\end{tabular}

"See Figure 8.1 
The BMP for the Paducah Site consists of three major tasks: (1) effluent and ambient toxicity monitoring, (2) bioaccumulation studies, and (3) ecological surveys of stream communities (i.e., benthic macroinvertebrates and fish). A summary of the BMP activities from January to December 1995 is provided, although activities conducted outside this time period are included as appropriate. A detailed report of the 1995 BMP was published in April 1996 (Kszos 1996) and is available from the National Technical Information Service, U.S. Department of Commerce.

\section{Study Area}

Three sites on Big Bayou Creek-Big Bayou Creek kilometer (BBK) 12.5, BBK 10.0, and BBK 9.1 - one site on Little Bayou Creek, Little Bayou Creek kilometer (LUK) 7.2 (Fig. 8.2); and one offsite reference station on Massac Creek, Massac Creek kilometer (MAK) 13.8, were routinely sampled to assess the ecological health of the stream and to evaluate ambient toxicity. Three additional sites (BBK 2.8, LUK 9.0, and LUK 4.3) were sampled as part of the bioaccumulation monitoring task, and one additional site was sampled in 1995 as part of the toxicity monitoring task (BBK 10.8). Qualitative fish community sampling is conducted at LUK 4.3. Toxicity monitoring and benthic macroinvertebrate sampling were conducted quarterly, and fish community and bioaccumulation sampling were conducted twice annually in the spring and fall. KPDES outfalls evaluated for effluent toxicity in 1995 included 001, 006, 008, $009,010,013,015,016,017$, and 018.

\section{Toxicity Monitoring}

The toxicity of effluents from the continuously flowing outfalls $(001,006,008,009$, and 010$)$ and the intermittently flowing outfalls $(013,015,016$,

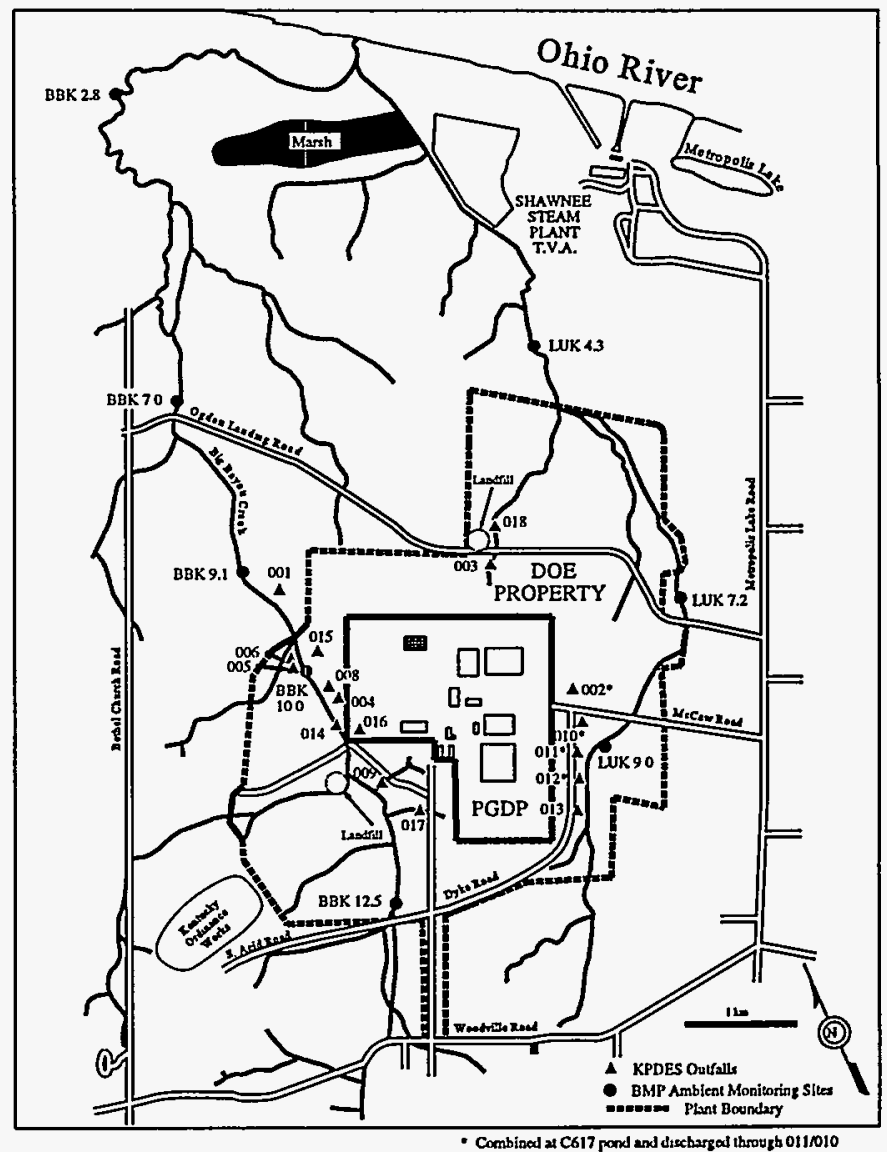

Figure 8.2 Biological Monitoring Sampling locations 017, and 018) were monitored for toxicity with water flea (Ceriodaphnia dubia) and fathead minnow larvae. Toxicity tests were conducted quarterly as required by the KPDES permit. Fathead minnow toxicity tests of water from ambient sites (BBK 12.5, BBK 10.8, BBK 9.1, LUK 7.2, and MAK 13.8) were conducted concurrently with the continuously flowing outfalls. Figure 8.2 shows the location of the ambient sites in relation to the continuous and intermittent outfalls. Tests with Ceriodaphnia and fathead minnows were typically conducted concurrently. The $25 \%$ inhibition concentrations (IC25: that concentration causing a $25 \%$ reduction in fathead minnow growth or Ceriodaphnia reproduction compared with the control) were determined for each test. The chronic toxicity unit rating (TUc=100/IC25) is required as a compliance endpoint in the renewed permit (September 1992 to present). The higher the 
TUc, the more toxic an effluent. Because Little Bayou and Big Bayou creeks have been determined to have a low flow of zero, a TUc $>1.0$ would be considered a noncompliance (for the continuously flowing outfalls) and an indicator of potential instream toxicity.

During 1995, effluent from Outfall 001 exceeded the permit limit of TUc $>1.0$ twice. No toxicity was evident in effluent samples from 006, 008, 009, or 010 during 1995. This is an improvement from the number of permit exceedances in previous years. During 1995, no toxicity was observed in effluent samples from 013, 015, 016, and 017. Outfall 018 exceeded a TUc $>1.0$ twice in 1995. In previous years, each of the intermittent outfalls exceeded a TUc $>1.0$ on several occasions. The intermittent outfalls are consistently more toxic (as determined by the TUc) to fathead minnow larvae than Ceriodaphnia.

During 1995, there was no consistent evidence of chronic toxicity to fathead minnows for any of the ambient sites. This is consistent with findings from 1991 to 1994 . There has been no consistent evidence of chronic toxicity in water from the ambient locations, no correlation of reductions in fathead minnow survival at the continuously flowing outfalls with reductions in fathead minnow survival at the ambient locations, and no significant change in water chemistry from the ambient sites or outfalls.

The influence of discharges from the Paducah Site on the water chemistry of Big Bayou and Little Bayou creeks is shown by the changes in alkalinity, $\mathrm{pH}$, hardness, and conductivity at sites downstream of those discharges, Figures 8.3 and 8.4. An analysis of mean water chemistry of outfalls or ambient water between years shows that there is very little temporal change in the characteristics of water from the outfalls or from the sites. Each year, the water chemistry data shows the influence of effluent from Outfalls 001 and 006 on the water chemistry of Big Bayou Creek: (1) conductivity and hardness are significantly higher at BBK 9.1 than BBK 10.0, and (2) $\mathrm{pH}$ is often higher at BBK 9.1 than BBK 10.0. An immediate decrease in alkalinity occurs in about $50 \%$ of the tests at sites below plant operations. Because alkalinity is also highly variable at the site above the Paducah Site discharges (BBK 12.5), the magnitude of the change in alkalinity with distance downstream in Big Bayou Creek seems to be linked to natural variations in flow (e.g., rainfall).

\section{Bioaccumulation Monitoring}

The primary objective of bioaccumulation monitoring in 1994-95 was to evaluate spatial and temporal changes in PCB contamination in sunfish from Big Bayou Creek and Little Bayou Creek. Because sunfish are short-lived and have small home ranges, they reflect recent contaminant exposure at the site of collection and are thus ideal monitoring tools for evaluating trends in contamination. To evaluate the maximum concentrations likely in fish near the Paducah Site, larger fish (i.e., bass) were analyzed for mercury and polychlorinated biphenyls (PCBs).

Mean PCB concentrations in sunfish from Little Bayou and Big Bayou creeks were higher than in fish from reference areas in both October 1994 and April 1995, see Table 8.6. The highest concentrations continued to be in fish from upper Little Bayou Creek, with a sharp decrease in contamination with increasing distance downstream. The strong downstream gradient in PCB contamination in Little Bayou Creek sunfish is consistent with the presence of PCB contamination near or within the plant that is diluted 

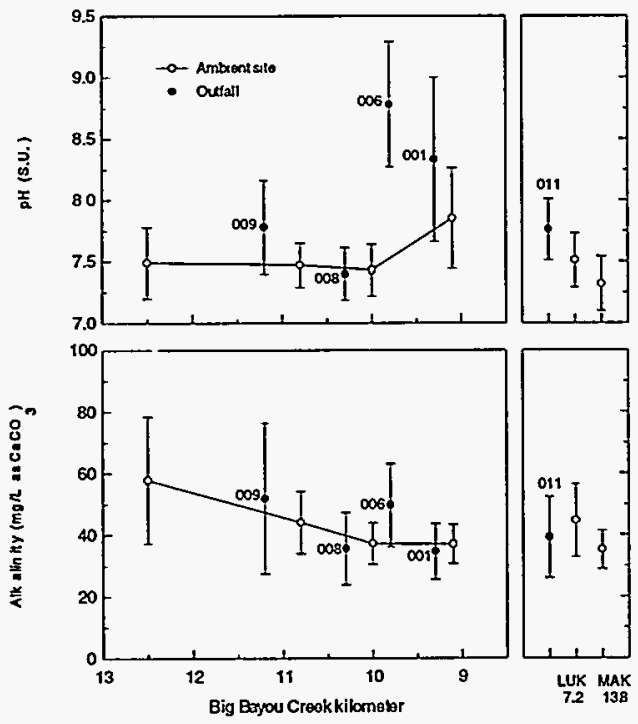

Figure 8.3 Summary of pH (mean \pm SD) and alkalinity (mean \pm SD) at Big Bayou Creek, Little Bayou Creek, and Massac Creek sites for 1991-95. Mean ( \pm SD) value of continuously flowing outfalls is also shown. $B B K=$ Big Bayou Creek kilometer; LUK = Little Bayou Creek kilometer; MAK = Massac Creek kilometer.
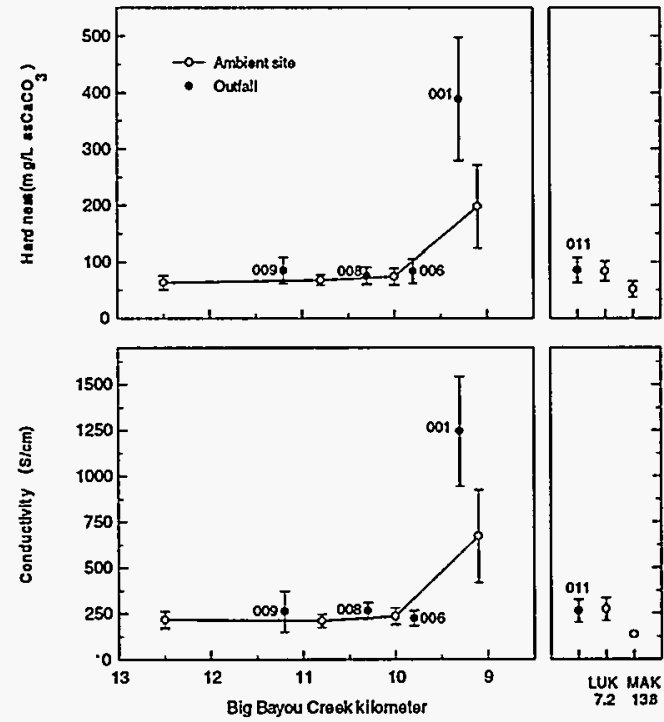

Figure 8.4 Summary of hardness (mean \pm SD) and conductivity (mean \pm SD) at Big Bayou Creek, Little Bayou Creek, and Massac Creek sites for 1991-95. Mean ( $\pm S D$ ) value of continuously flowing outfalls is also shown. $\mathrm{BBK}=$ Big Bayou Creek kilometer; LUK = Little Bayou Creek kilometer; MAK = Massac Creek kilometer.

with increased flow downstream. Historical PCB residues trapped in the plant storm-drain network or within upstream ditch or pond sediments may be the primary sources of PCBs to Little Bayou Creek.

In Big Bayou Creek, the mean PCB concetrations in the middle sections of the stream (BBK 9.1 and BBK 10.0) were again higher than the $\mathrm{PCB}$ concentrations in reference fish upstream of the plant outfalls, Table 8.6. As was the case in previous years, mean PCB concentrations at the two sites were similar, suggesting that outfall 001 (located between BBK 9.1 and BBK 10.0) is not a major contributor of PCBs to the system. The mean PCB concentration in sunfish from the most downstream site in Big Bayou Creek (BBK 2.8 ) in October 1994 was only slightly higher than the reference stream sites, indicating the PCB contamination in Big Bayou Creek is confined to the reach near the plant.

In October 1994, mean mercury and PCB concentrations in spotted bass from the two creeks were also elevated. However, PCB concentrations in these bass were not much higher than sunfish collected at the same sites, see Table 8.6. The highest mercury concentrations in fish from the Paducah Site vicinity 
continued to be in spotted bass collected from Big Bayou Creek. The mean mercury concentrations ( $\pm S E$ ) in bass sampled from Big Bayou and Little Bayou creeks were $0.43 \pm 0.05$ and $0.26 \pm 0.03$ respectively. The mean mercury concentrations in bass in October 1994, if adjusted for the difference in fish weight, was similar to the level of contamination observed in this species in previous years.

PCB concentrations in sunfish appeared to have decreased over time at all Little Bayou Creek and Big Bayou Creek sites from April 1992 to April 1995, although the extent of the decrease in upper Little Bayou Creek may have been due in part to habitat changes that affected the size and species of fish available, see Figure 8.5. $\mathrm{PCB}$ concentrations in fish from the most upstream site (LUK 9.0) exhibited a distinct seasonal pattern with the highest concentrations found in the spring of each year, suggesting higher flows may mobilize residual sources within the plant. The overall decreasing trend and the seasonal pattern of PCB contamination in fish near the plant is encouraging in that it suggests that sunfish are highly responsive to changes in plant practices and/or other in-plant remedial actions that reduce $\mathrm{PCB}$ inputs.
Table 8.6 PCB concentrations in fish $(\mu \mathrm{g} / \mathrm{g})$

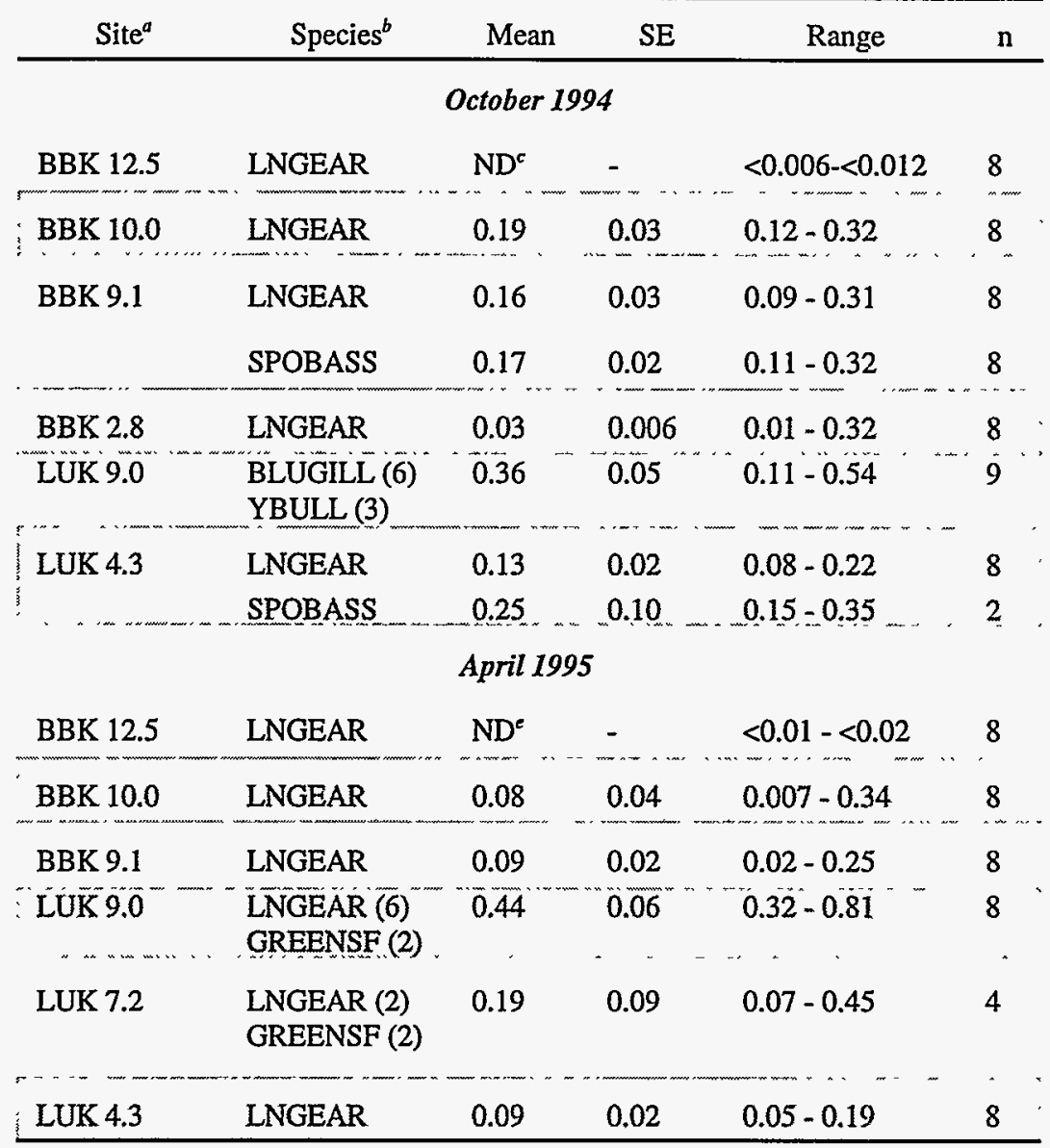

${ }^{a}$ BK=Big Bayou Creek kilometer, LUK=Little Bayou Creek kilometer.

${ }^{b}$ LNGEAR = Longear sunfish (Lepomis megalotis); SPOBASS = Spotted bass (Micropterus punctulatus); REDBRE = Redbreast sunfish (Lepomis megalotis); BLUGILL = Bluegill (Lepomis macrochirus); YBULL = Yellow bullhead (Ameiurus natalis); GreenSF = Green sunfish (Lepomis cyanellus).

c Not Detectable

e One of eight fish was higher than the detection limit. 


\section{Ecological Monitoring}

\section{Fish community monitoring}

The fish communities of streams bordering the Paducah Site are assessed by sampling at three sites in Big Bayou Creek, one site in Little Bayou Creek, see Figure 8.2, and at one off-site reference station (Massac Creek) during spring and fall. The sampling, shown in Figure 8.6, consists of isolating a 100meter section of stream with nets and using electrofishers to capture all fish

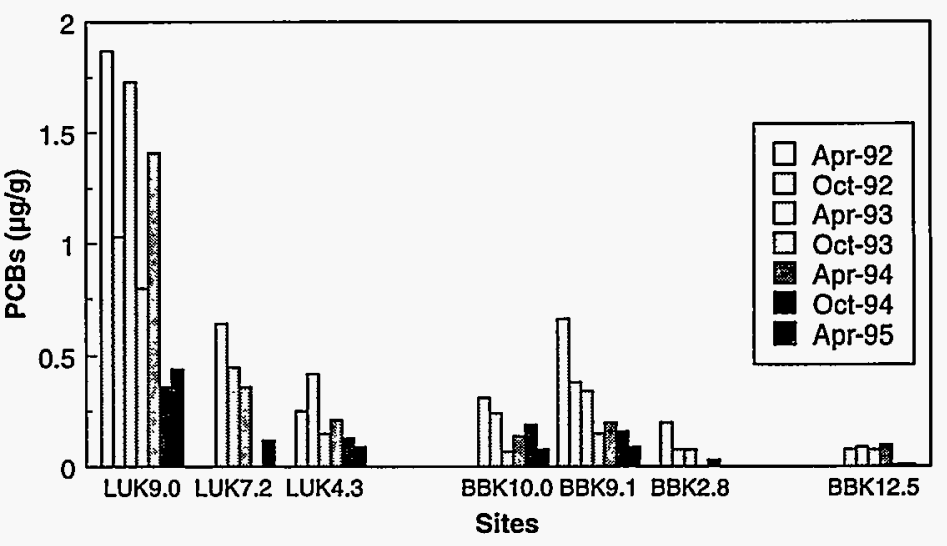

Figure 8.5 Historical PCB concentrations in sunfish within the nets. These fish are then identified, measured for length and weight, and returned alive to the stream. The resulting data can indicate impacts of plant operations by following changes in total number of species, types of species present, density of individual species, and biomass of the community.

Data on the fish communities gathered since 1991 for Big Bayou Creek and Little Bayou Creek downstream of the Paducah Site were compared to data from reference sites located on Big Bayou Creek above the Paducah Site and on Massac Creek, see Figures 8.7 and 8.8. These comparisons indicated a slight but noticeable degradation in the communities downstream of the Paducah Site. Effects on the fish community were greatest just downstream from the Paducah Site at BBK 10.0. The fish community at this site had a low number of species and there was only one species considered sensitive to stress, whereas there were six sensitive species at the Massac Creek reference site. The lower species numbers, compared with reference sites, may be a result of thermal impacts associated with outfalls (e.g., Outfall 008). Although the temperatures may not be lethal, they could produce avoidance of the areas of Big Bayou Creek near the

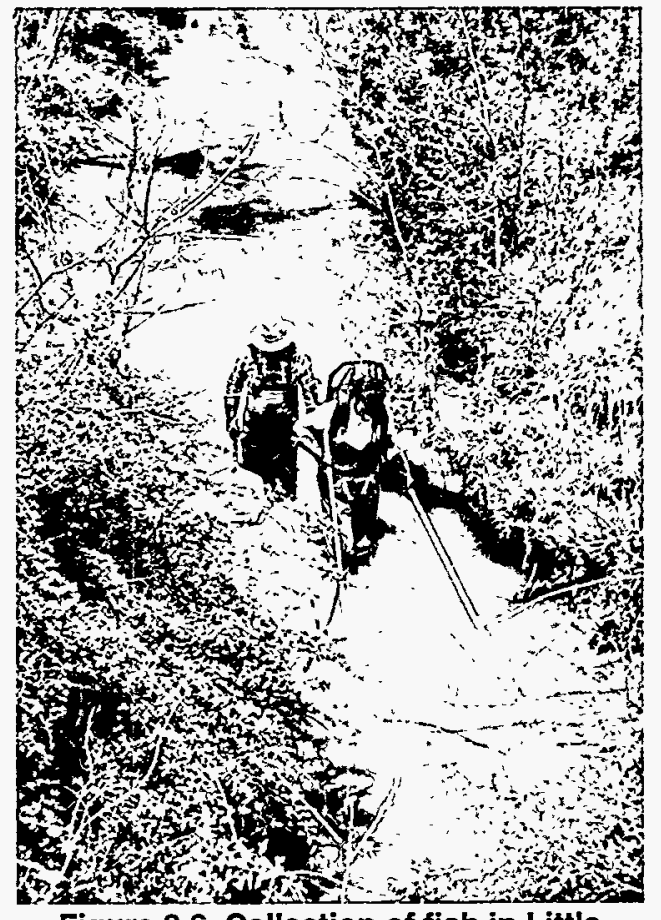

Figure 8.6 Collection of fish in Little Bayou Creek. plant outfalls. Density at BBK 10.0 was similar to or higher than that at the reference sites, with a correspondingly high biomass. Density and biomass were dominated by one species, the herbivore stoneroller. This numerical dominance by a herbivorous species, combined with the low numbers of benthic insectivores, suggests possible nutrient enrichment at BBK 10.0, perhaps associated with discharges from Outfall 004. 
Downstream in Big Bayou Creek the fish community at BBK 9.1 showed signs of impact but at less severe levels than at BBK 10.0. Total number of species was lower than at MAK 13.8 but similar to BBK 12.5. Although there were fewer sensitive species and at lower densities at BBK 9.1 than at MAK 13.8, more sensitive species were found at BBK 9.1 than at BBK 10.0.
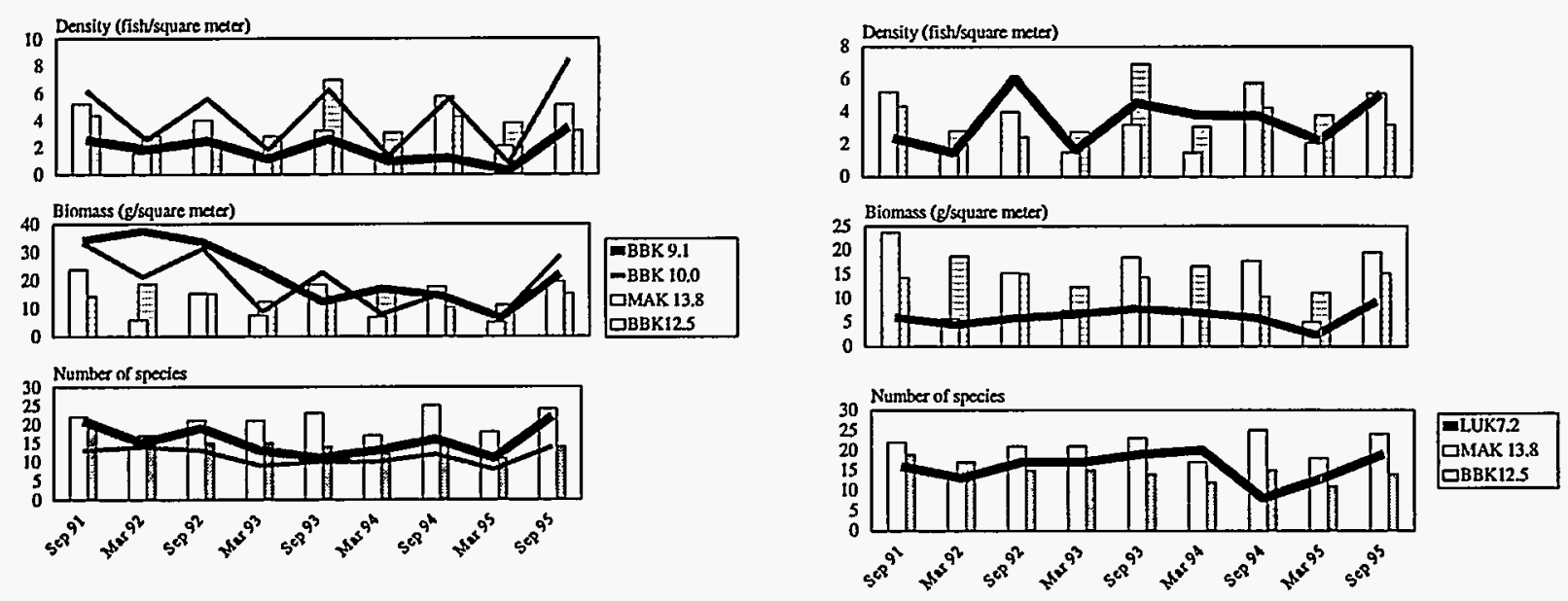

Figure 8.7 Number of species, biomass, and density at Big Bayou sites.

Figure 8.8 Number of species, biomass, and density at Little Bayou Sites.

The fish community at LUK 7.2 was similar to that at the BBK 12.5 reference site, see Figure 8.8, with perhaps some species deficiencies. The species numbers were similar to those of the reference site and had rebounded substantially from a low point in fall 1994. Density and biomass also reached near record levels for this site in September 1995.

Monitoring of the fish communities associated with the Paducah Site streams indicated some depressed conditions but did not specifically identify causative agents. The impacts were limited to sites closest to the plant, which suggests that the Paducah Site discharges (with resultant temperature increases and nutrient enrichment) may be the cause. It is also possible that the low species richness and lack of sensitive species may reflect degraded habitat conditions or be a common characteristic of the Big Bayou Creek watershed. To help identify causative agents, a network of temperature recorders will continue to be deployed at sampling sites to evaluate possible thermal impacts.

\section{Benthic macroinvertebrate community monitoring}

The objectives of the benthic macroinvertebrate monitoring task are to assess the ecological condition of the two streams receiving effluents from the Paducah Site, and document any changes in macroinvertebrate community composition over time. Quantitative samples are collected at three sites on Big Bayou Creek and one site on Little Bayou Creek, see Figure 8.2; an additional reference site is located outside the Paducah Site boundary on Massac Creek. Macroinvertebrate densities at all sites were comparable for the 
period September 1991-March 1995. The occasional substantial increase in the number of organisms at BBK 9.1 may be the result of a sustained period of habitat stability or a short-term increase in nutrient availability. Although BBK 9.1 had substantially higher densities than the reference sites on four occasions, during the majority of the period no site was consistently different from the other sites, see Figure 8.9. Only BBK 10.0 had a significant negative trend in densities during each sampling season; however, during September 1991-March 1995, density at BBK 10.0 generally fell within the range exhibited by the reference sites. Data from future collections should determine whether this is a sustained trend or natural variation. Likewise, additional data will be needed to determine whether the positive trend in densities in the winter samples at LUK 7.2, in addition to the high densities in March 1995, indicate community improvement or result from seasonal variation.

The macroinvertebrate community composition at the sites receiving the Paducah Site discharges were generally similar to one or both of the reference sites, see Figure 8.10. In addition, there were no consistent spatial or temporal trends in either densities or mean number of sensitive taxa (mayflies, stoneflies, and caddisflies) that provided strong evidence of major impacts to the macroinvertebrate communities at BBK 9.1, BBK 10.0, or LUK 7.2, see Figure 8.9. However, the inability to detect statistically significant trends from the available data does not necessarily indicate that significant differences do not exist between the sites. The considerable spatial and temporal variability present in the data may have masked subtle impacts. 


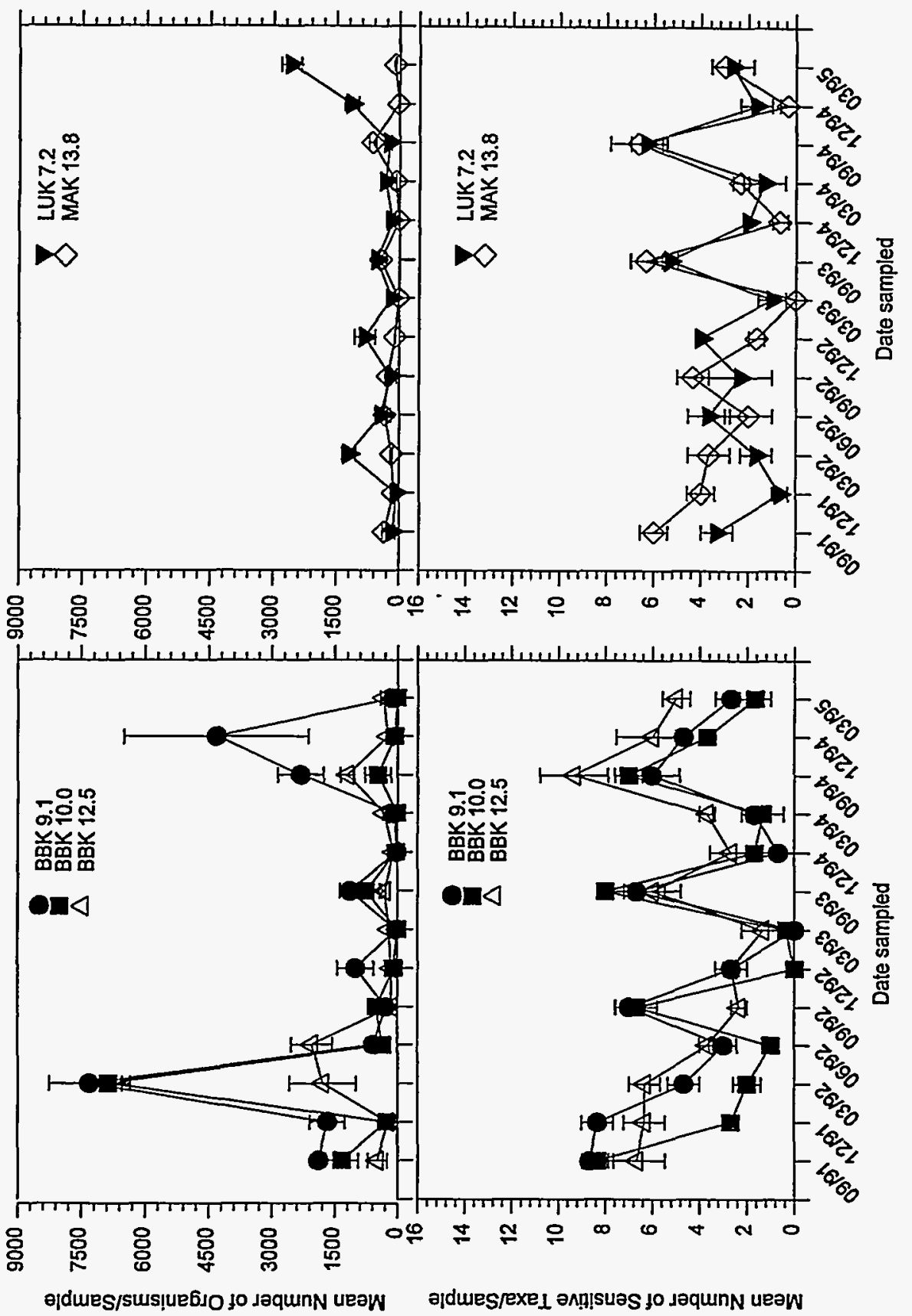

Figure 8.9 Mean number of organisms and mean number of sensitive taxa (mayflies, stoneflies, and caddisflies) of the riffle communities in Big Bayou Creek, Little Bayou Creek, and Massac Creek, September 1991 to March 1995. Vertical bars are \pm 1 SE. $\mathrm{BBK}=$ Big Bayou Creek kilometer; LUK = Little Bayou Creek kilometer; MAK = Massac Creek kilometer.

Nonradiological Environmental Surveillance 


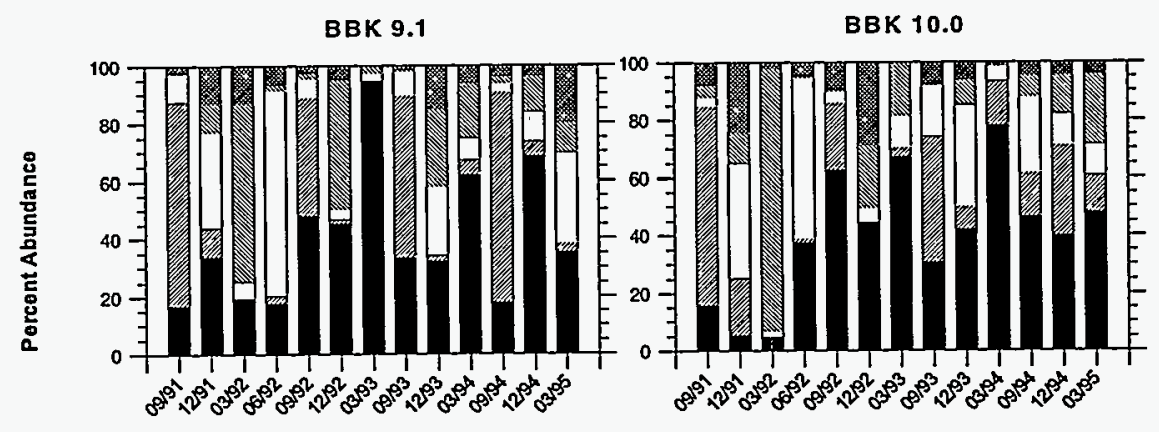

BBK 12.5

LUK 7.2
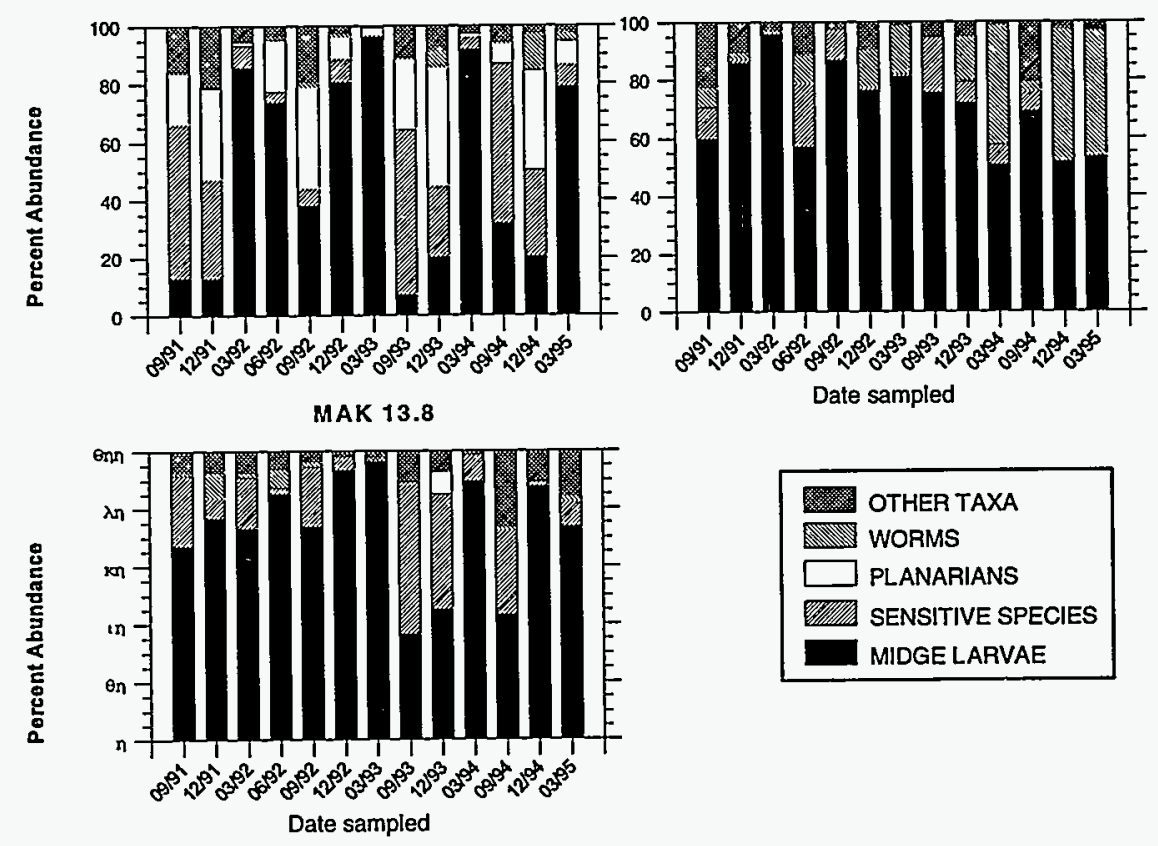

Figure 8.10 Mean percent abundance of selected benthic macroinvertebrate taxa in Big Bayou Creek, Little Bayou Creek, and Massac Creek, September 1991 to March 1995. BBK = Big Bayou Creek kilometer; LUK = Little Bayou Creek kilometer; MAK = Massac Creek kilometer.

\section{Nonradiological Environmental Surveillance}




\section{Terrestrial Wildlife}

Because DOE retains responsibility for historic releases, the deer population is sampled annually to look for any increases in inorganic elements that might be attributed to past plant practices. There were nine deer harvested from the area surrounding the Paducah Site and three deer harvested at Fort Campbell, Kentucky to serve as background samples. Neither PCBs in fat nor technetium $\left({ }^{99} \mathrm{Tc}\right)$ in thyroid were detectable in any of the eleven deer harvested. Tables 8.7 and 8.8 show the analytical results for inorganics in liver and muscle tissue, respectively. When compared to 1993 and 1994 data, no unusual levels of inorganic elements were identified.

Table 8.7 Analysis of deer liver tissue for 1995

\begin{tabular}{|c|c|c|c|c|c|c|c|c|c|c|c|c|}
\hline \multirow{2}{*}{ Deer } & \multicolumn{12}{|c|}{ Inorganic $\mu \mathrm{g} / \mathrm{g}$} \\
\hline & $\mathrm{Ba}$ & $\mathrm{Cd}$ & $\mathrm{Ca}$ & $\mathrm{Cr}$ & $\mathrm{Cu}$ & $\mathrm{Fe}$ & $\mathrm{Mg}$ & $\mathrm{Mn}$ & $\mathrm{P}$ & $\mathrm{Se}$ & $\mathrm{Ag}$ & $\mathrm{Zn}$ \\
\hline 1 & $\mathrm{ND}^{a}$ & ND & 77.5 & ND & 8.8 & ND & 157 & ND & 2530 & ND & 0.56 & 25.3 \\
\hline 2 & ND & ND & 76.1 & ND & 32.9 & ND & 168 & ND & 3530 & ND & ND & 27.8 \\
\hline 3 & ND & $\mathrm{ND}$ & 74.8 & ND & 35.7 & ND & 154 & ND & 3230 & ND & 0.29 & 32.3 \\
\hline 4 & 0.17 & 0.16 & ND & 0.53 & ND & ND & 150 & 3.2 & 3410 & 2.3 & ND & 37.9 \\
\hline 5 & 0.11 & 0.21 & ND & 0.28 & ND & ND & 141 & 3.3 & 3230 & 0.76 & 0.23 & 37.8 \\
\hline 6 & 0.41 & 0.29 & ND & 0.38 & ND & ND & 149 & 3.8 & 3410 & 1.3 & ND & 32.5 \\
\hline 7 & 0.27 & 0.31 & ND & 0.39 & 92.2 & 40.7 & 142 & 3.7 & 3260 & 0.8 & 0.4 & 34.7 \\
\hline 8 & 0.22 & 0.31 & ND & 0.29 & 96.7 & 45 & 122 & 3 & 2800 & ND & ND & 31.9 \\
\hline 9 & 0.4 & 0.22 & ND & 0.45 & 36.7 & 67 & 150 & 3.5 & 3440 & 0.48 & ND & 40.5 \\
\hline \multicolumn{13}{|c|}{ Background Deer } \\
\hline 10 & ND & ND & ND & ND & 0.66 & ND & ND & ND & 2170 & ND & ND & 21.1 \\
\hline 11 & ND & 0.3 & ND & ND & 87 & ND & ND. & ND & 2940 & ND & ND & 32.2 \\
\hline 12 & ND & ND & ND & ND & 5.1 & ND & 124 & ND & 2420 & ND & ND & 29.7 \\
\hline
\end{tabular}

${ }^{a}$ Not Detectable

In summary, there were no unusual finds in the 1995 deer data. When comparing Paducah Site deer data to the background deer data, the results were not substantially greater. The data will be assessed in future sampling events to identify any potential trends.

Nonradiological Environmental Surveillance 
Table 8.8 Analysis of deer muscle tissue for 1995

\begin{tabular}{|c|c|c|c|c|c|c|c|c|c|c|c|c|c|}
\hline \multirow{2}{*}{ Deer } & \multicolumn{13}{|c|}{ Inorganic $\mu \mathrm{g} / \mathrm{g}$} \\
\hline & $\mathrm{Al}$ & $\mathrm{Ba}$ & $\mathrm{Ca}$ & $\mathrm{Cr}$ & $\mathrm{Cu}$ & $\mathrm{Fe}$ & $\mathrm{Mg}$ & $\mathrm{Mn}$ & $\mathrm{P}$ & $\mathrm{Se}$ & $\mathrm{Ag}$ & $\mathrm{V}$ & $\mathrm{Zn}$ \\
\hline 1 & $\mathrm{ND}^{a}$ & ND & 92.4 & ND & 4.2 & ND & 251 & ND & 2130 & ND & ND & ND & 17.2 \\
\hline 2 & ND & ND & 89.3 & ND & 1.4 & ND & 256 & ND & 2230 & ND & ND & ND & 15.8 \\
\hline 3 & ND & ND & 66.5 & ND & 1.4 & $\mathrm{ND}$ & 250 & ND & 2140 & $\mathrm{ND}$ & ND & $\mathrm{ND}$ & 13.1 \\
\hline 4 & ND & 0.16 & ND & 0.21 & 1.2 & ND & 241 & 0.21 & 2200 & ND & $\mathrm{ND}$ & ND & 15.3 \\
\hline 5 & ND & 0.21 & ND & ND & 1.1 & ND & 251 & ND & 2220 & ND & 15.4 & ND & 22.9 \\
\hline 6 & ND & 0.29 & ND & ND & 1.0 & ND & 229 & ND & 2120 & ND & ND & ND & 19.1 \\
\hline 7 & ND & 0.31 & ND & 0.52 & 0.76 & 50.9 & 215 & $\mathrm{ND}$ & 1910 & ND & ND & ND & 14.3 \\
\hline 8 & 4.1 & 0.31 & ND & 0.32 & 1.5 & 33.8 & 219 & ND & 2020 & 0.55 & ND & 0.25 & 22.8 \\
\hline 9 & $\mathrm{ND}$ & 0.22 & ND & ND & ND & 27.8 & 260 & ND & 2130 & ND & ND & ND & 20.3 \\
\hline \multicolumn{14}{|c|}{ Background Deer } \\
\hline 10 & ND & ND & ND & $\mathrm{ND}$ & 1.1 & ND & ND & $\mathrm{ND}$ & 2200 & ND & ND & ND & 12.5 \\
\hline 11 & ND & $\mathrm{ND}$ & ND & ND & 1.1 & ND & ND & $\mathrm{ND}$ & 2060 & ND & ND & ND & 9.9 \\
\hline 12 & ND & ND & ND & ND & 1.0 & ND & ND & ND & 2250 & ND & ND & ND & 12.5 \\
\hline
\end{tabular}




\title{
9. Groundwater
}

\begin{abstract}
The primary objectives of groundwater monitoring at the Paducah Site are to detect contamination and provide the basis for groundwater quality assessments if contamination is detected. Monitoring includes the exit pathways at the perimeter of the plant and off-site water wells. Primary off-site contaminants were determined to be trichloroethylene, an industrial degreasing solvent, and technetium-99, a fission by-product. Evidence suggests the presence of dense nonaqueous phase liquids on-site.
\end{abstract}

\section{Introduction}

Monitoring and protection of groundwater resources at the Paducah Site are required by federal and state regulations and by Department of Energy (DOE) orders. Federal groundwater regulations generally are enacted and enforced by the Environmental Protection Agency (EPA). The Paducah Site lies within EPA Region IV jurisdiction. EPA Region IV encompasses the southeastern United States and maintains headquarters in Atlanta. Many state groundwater regulations are enacted and enforced by the Kentucky Department of Waste Management (KDWM) in Frankfort, Kentucky. A KDWM field office for western Kentucky is located in Paducah.

When off-site contamination from the Paducah Site was discovered in 1988, the EPA and DOE entered into an Administrative Consent Order (ACO). DOE provided an alternate water supply to affected residences. Under Comprehensive Environmental Response, Compensation, and Liability Act (CERCLA), $\mathrm{DOE}$ was required to determine the nature and extent of off-site contamination through sampling of potentially affected wells and a comprehensive site investigation.

The CERCLA/ACO site investigation, completed in 1991, determined off-site contaminants in the regional gravel aquifer (RGA) to be trichloroethylene (TCE), an industrial degreasing solvent, and technetium $\left({ }^{99} \mathrm{Tc}\right)$, a fission by-product contained in nuclear power reactor returns that were brought on-site several years ago for re-enrichment. Such reactor returns are no longer enriched. Known or suspected sources of TCE include burial grounds, test areas, and other operating facilities. Likely ${ }^{99} \mathrm{Tc}$ sources are spills and leaks of contaminated TCE and leachate derived from contaminated scrap metal.

Investigation into the contamination at the Paducah Site is ongoing. A major finding is the presence of dense nonaqueous phase liquids (DNAPLs) on-site. DNAPLs are liquids with densities greater than water (degreasing agents are common DNAPLs). DNAPLs typically have low solubilities in water and sink to the bottom of aquifers, or come to rest upon a less permeable layer within an aquifer, forming pools. DNAPLs form a continuing source of dissolved-phase pollution that is difficult to remove. The dissolved-phase groundwater contamination from the plant is migrating toward the Ohio River. Continued groundwater monitoring serves to identify the extent of contamination, predict the possible fate of the contaminants, and determine the movement of groundwater near the plant. 
Groundwater monitoring at Paducah complies with one or more federal or state regulations and permit conditions and includes perimeter exit-pathway monitoring and off-site water well monitoring. A more detailed description of groundwater monitoring is under "Groundwater Monitoring Program." Figures 9.1 through 9.6 show the locations of all wells sampled during 1995 . Analytical results from the sampling described in this section are available upon request from the Public Affairs Group.

\section{Groundwater Hydrology}

A portion of rainwater accumulates as groundwater by soaking into the ground, infiltrating porous soil and rock. The accumulation of groundwater in pore spaces of sediments creates a source of useable water-an aquifer, see Figure 9.7. Water from the surface moving down through the soil makes its way by percolating downward through the pore spaces between soil grains, see Figure 9.8. The smaller the pore spaces, the slower the flow of water through the sediment. The physical property that describes the ease with which water can move through the pore spaces and fractures in a material is called hydraulic conductivity, or permeability. Permeability is determined not only by the volume and size of the pore spaces but also by how well

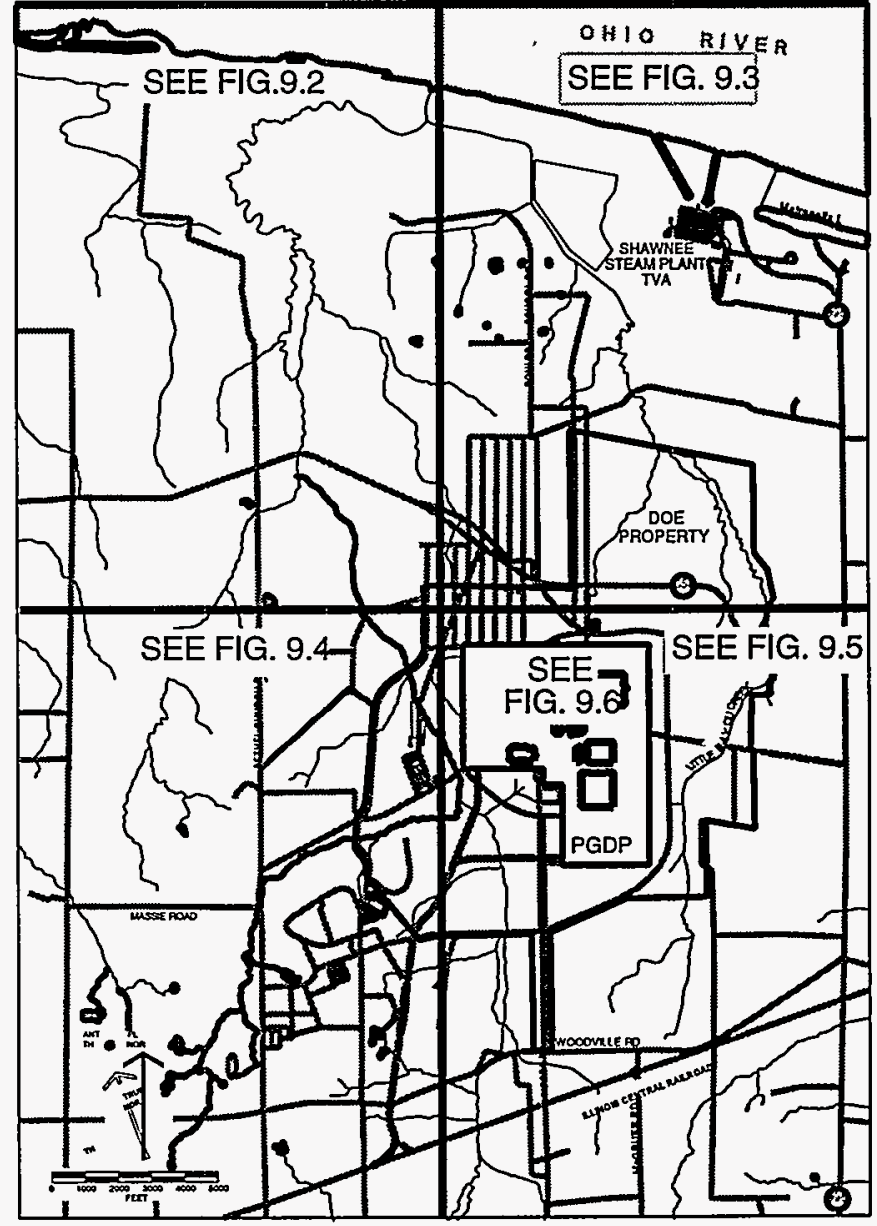

Figure 9.1 Wells sampled at the Paducah Site in 1995 (by sectors) the pore spaces are connected. Aquifers are found in permeable sediments (such as sand and gravel) and rocks (such as sandstone and fractured limestone). Less permeable sediments (such as clay) and rocks (such as shale and dense limestone) make up aquitards that restrict groundwater movement. The boundary between the unsaturated and the saturated zones is known as the water table. This boundary usually, but not always, gently mirrors the surface topography, rising above natural exits such as springs, swamps, and beds of streams and rivers, where groundwater is discharged to the surface. Groundwater movement is determined by differences in hydraulic head (a function of the energy associated with the water's elevation above sea level and the pressures exerted on it by surrounding water). Water will rise in a well casing in response to the pressure of the water surrounding the well's screened zone. The depth to water in the well is measured and the elevation calculated to determine the hydraulic head of the water in the monitored zone, see Figure 9.9. The hydraulic gradient measures the difference in hydraulic head over a specified distance. By comparing the water levels in adjacent wells screened in the same zone, a horizontal hydraulic gradient can be determined and the lateral direction of groundwater flow can be predicted. Only wells screened in the same zones are considered when determining the horizontal gradient. Wells screened above and below an aquitard can also have different hydraulic heads, thus defining a vertical gradient. 

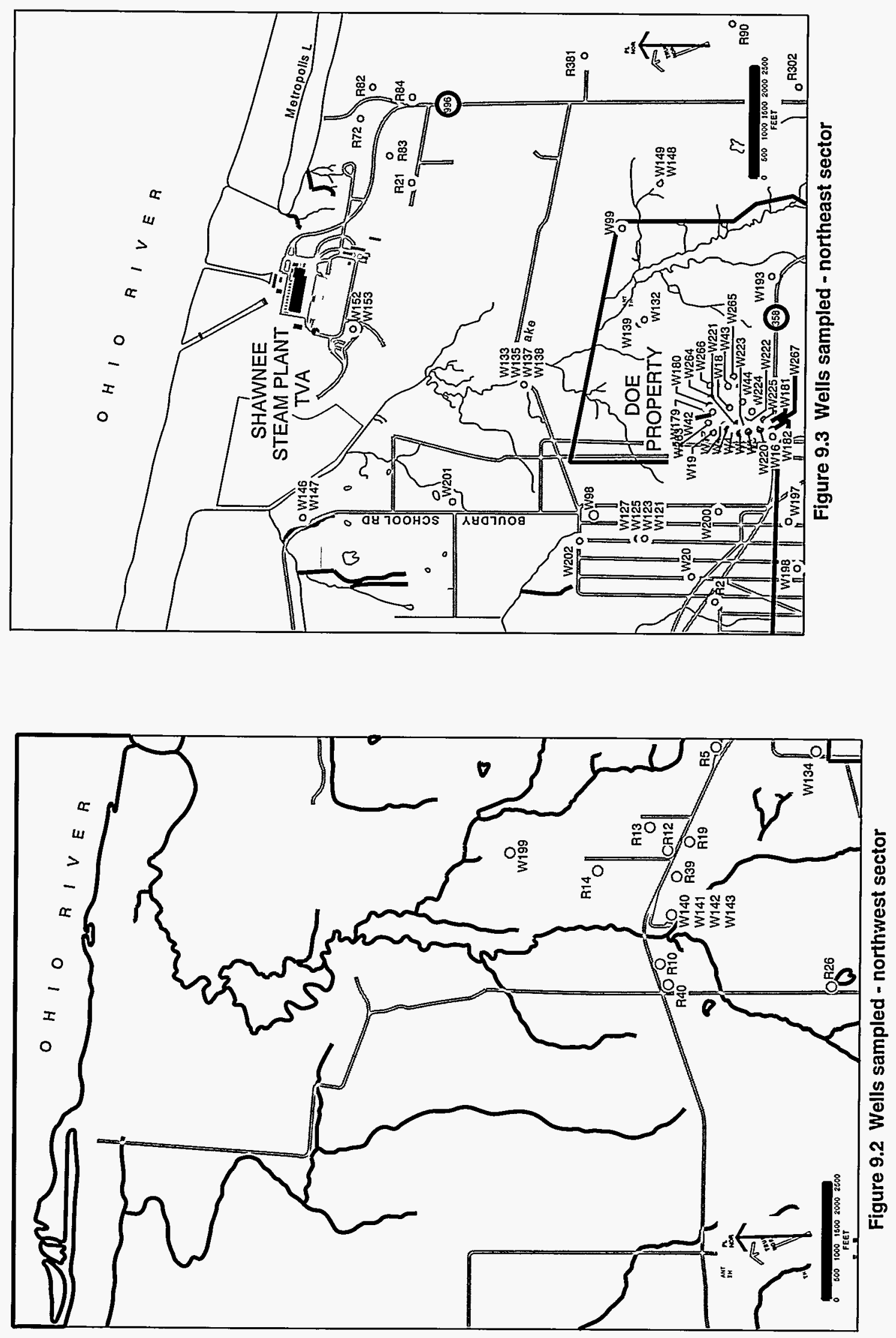


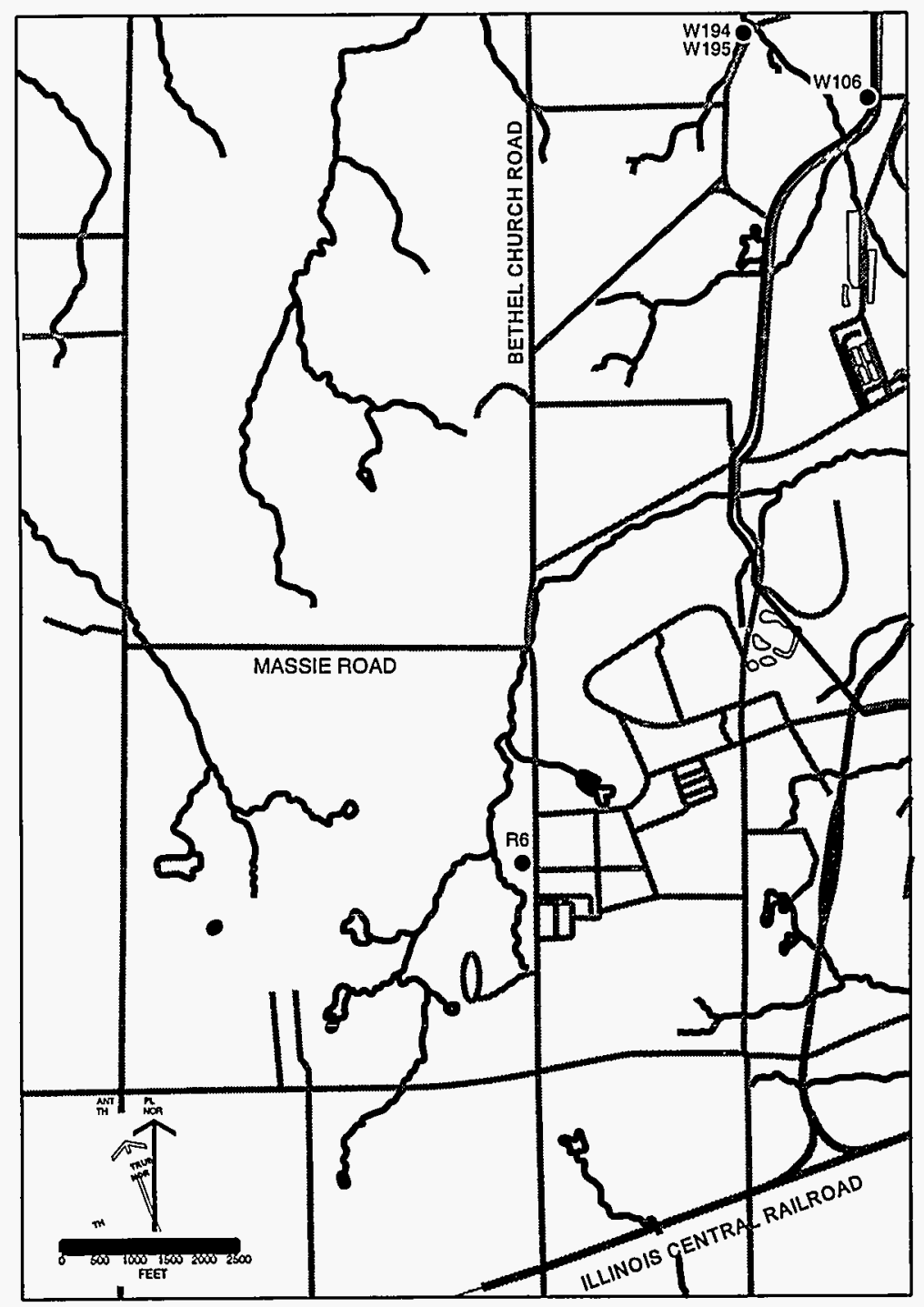

Figure 9.4 Wells sampled - southwest sector

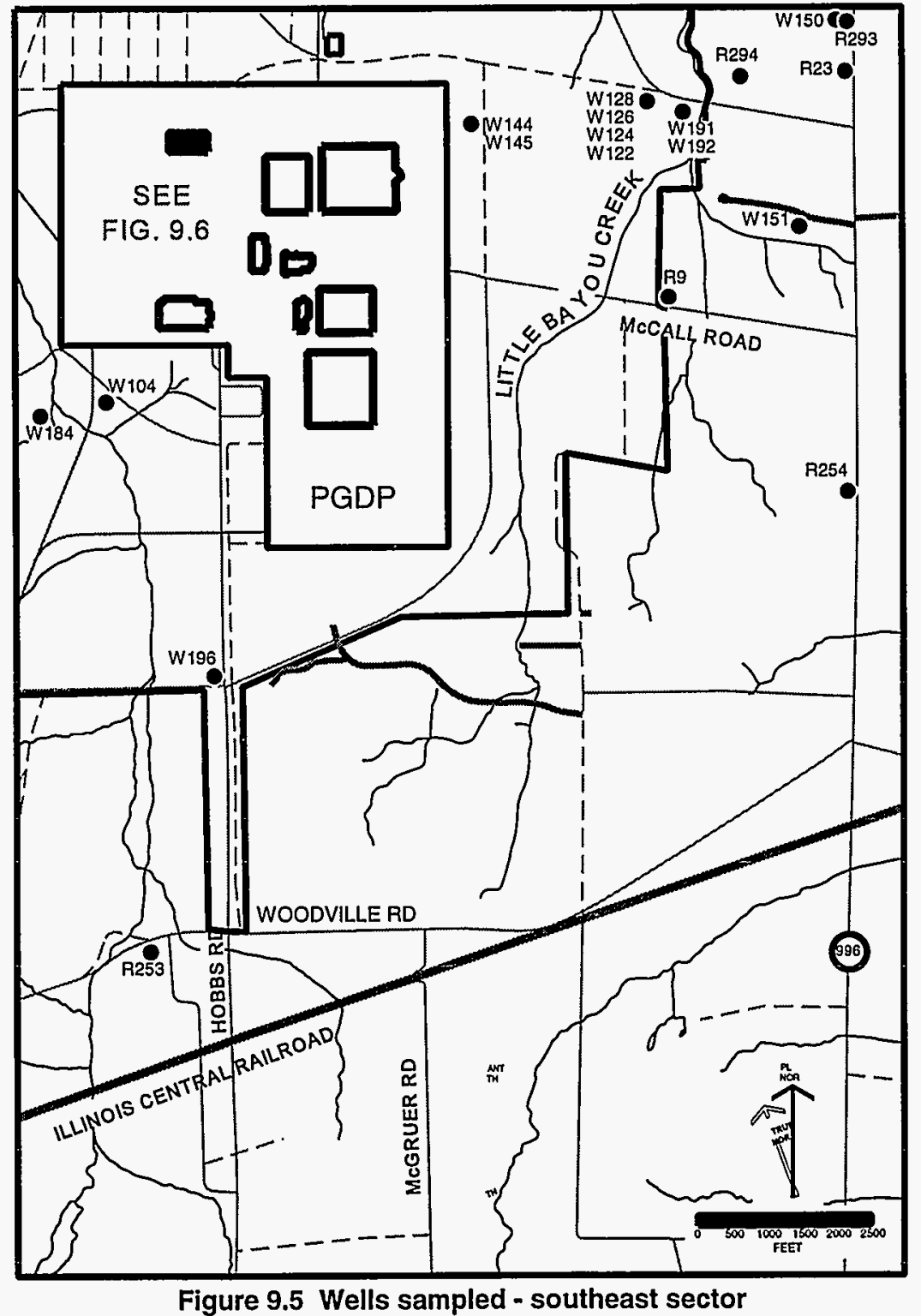

Figure 9.5 Wells sampled - southeast sector 


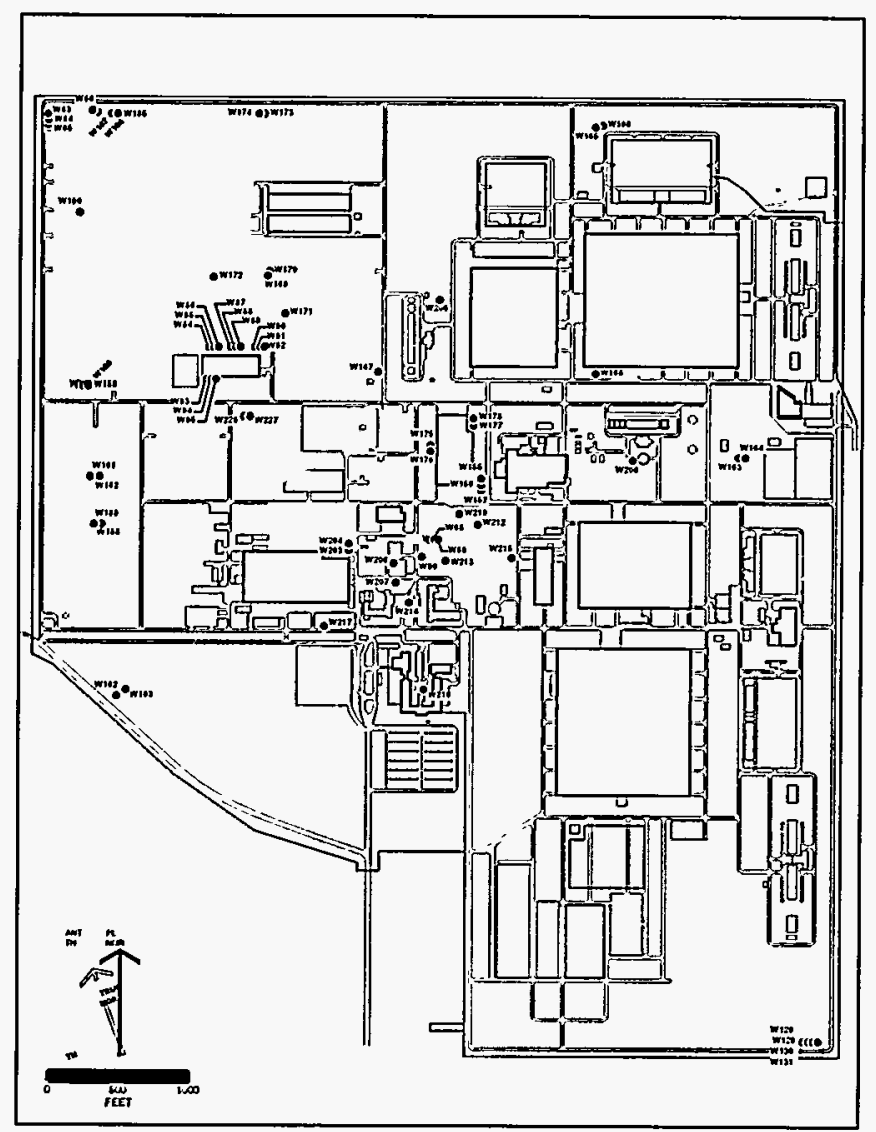

Figure 9.6 Wells sampled - plant site

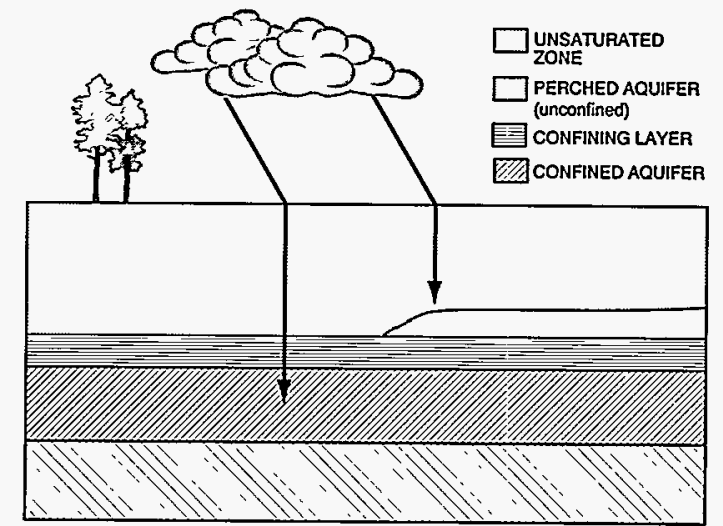

Figure 9.7 Typical path for rainwater accumulation as groundwater.

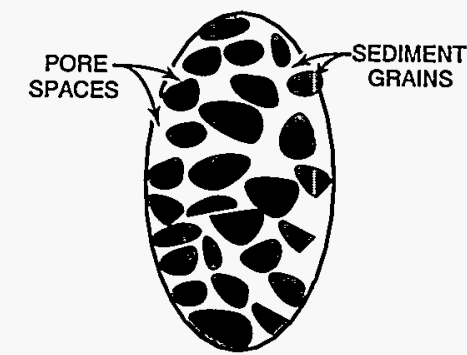

Figure 9.8 Pore spaces in soil.

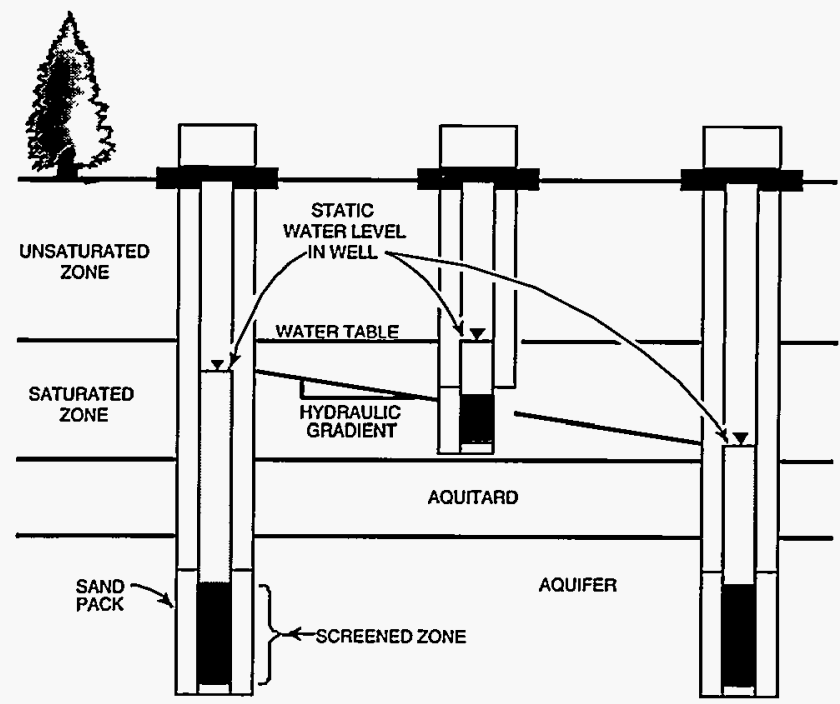

Figure 9.9 Monitoring well construction showing relationship between screened zone and water level in wells where limited flow through the aquitard is downward and flow in the aquifer is to the right. 
If the water levels in deeper wells are lower than those in shallower wells, the vertical component of flow is downward.

Permeability of the subsurface strata containing the aquifer also plays an essential role in the direction of groundwater flow through an aquifer system. Because the earth's sediments and their permeability vary greatly, groundwater flowing through subsurface strata does not travel at a constant rate or without impediment. As groundwater moves in the downgradient direction, it has both a horizontal and a vertical component, just as a household drain moves tap water both horizontally and vertically, seeking the lowest point of exit. Aquitards deflect groundwater movement as drainpipe walls control the direction of tap water movement. In an aquifer constrained by aquitards such as horizontal clay layers, the downgradient direction tends to be more horizontal than vertical.

Groundwater aquifers are one of the primary pathways by which potentially hazardous substances can spread through the environment. Substances placed in the soil may migrate downward due to gravity or be dissolved in rainwater, which moves them downward through the unsaturated zone into the aquifer. The contaminated water then flows downgradient toward the discharge point. Monitoring wells are used extensively to assess the effect of plant operations on nearby groundwater quality. Wells positioned to sample groundwater flowing away from a site are called downgradient wells, and wells placed to sample groundwater before it flows under a site are called upgradient wells. Any contamination of the downgradient wells not present in the upgradient wells at a site may be assumed to be a product of that site. Wells can be drilled to various depths in the saturated zone and be screened to monitor the recharge area above the aquifer, different horizons of the aquifer, or water-bearing zones below the aquifer.

Vertical and horizontal groundwater flow directions are determined by the permeability and continuity of geologic strata in addition to hydraulic head. To effectively monitor the movement of groundwater and any hazardous constituents it may contain, hydrogeologists at the Paducah Site have undertaken many detailed studies of the geology of strata beneath the site.

\section{Geologic and Hydrogeologic Setting}

The Paducah Site, located in the Jackson Purchase region of western Kentucky, lies within the northern tip of the Mississippi Embayment portion of the Gulf Coastal Plain Province. The Mississippi Embayment is a large sedimentary trough oriented nearly north-south that received sediments during the Cretaceous and Tertiary geologic time periods. Figure 9.10 is a schematic cross-section illustrating regional stratigraphic relationships in the vicinity of the Paducah Site.
SOUTH

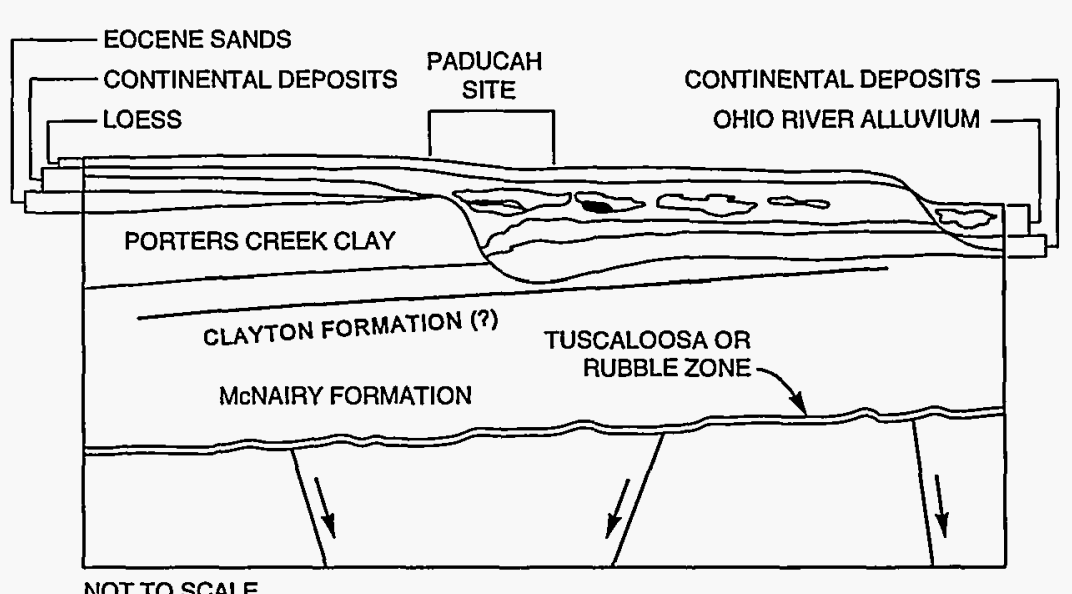

NOT TO SCALE

Figure 9.10 North-south section showing regional stratigraphic relationships. 
During the Cretaceous period, sediments deposited in a coastal marine environment formed the McNairy Formation. For the most part, the McNairy Formation is sandy at the bottom and silty at the top. A few exceptions to this are lenses of clay and at least one fairly continuous string of gravel.

Above the McNairy is the Clayton Formation. The Clayton was deposited during the early Paleocene geologic epoch in an environment so similar to that of the McNairy that the Clayton and upper portion of the McNairy are indistinguishable in lithologic samples. Later in the Paleocene, the Porters Creek Clay was deposited in marine and brackish water environments in a sea that occupied most of the Mississippi Embayment. These formations, the McNairy/Clayton and the Porters Creek Clay, dip 9 to $10.5 \mathrm{~m}$ (30 to 35 feet(ft)) per mile to the south-southwest.

The next feature in the geologic history at the Paducah Site is a Pleistocene-age river valley occupying approximately the same position as the present day Ohio and Tennessee river valleys. In forming the valley, braided stream channels of the ancestral Tennessee River, and possibly several "feeder" streams, eroded any sediments deposited after the Paleocene Porters Creek Clay and before the Pleistocene. The river system also eroded portions of the Porters Creek Clay and the McNairy/Clayton Formation and cut a prominent terrace in the Porters Creek Clay at the south end of the plant. The sediments deposited on this erosional surface are termed continental deposits. The lower portion of the continental deposits consists of approximately $9 \mathrm{~m}(30 \mathrm{ft})$ of stream gravel and sand.

Over time, sediments from the retreating glaciers dammed the river valley, causing the formation of a lake. Silts and clays with thin zones of sand and occasional gravel were deposited in the lake, forming the upper portion of the continental deposits. These deposits range from approximately 1.5 to $17 \mathrm{~m} \mathrm{(5} \mathrm{to} 55 \mathrm{ft}$ ) thick.

Finally, loess, a wind-blown silt, overlies the continental deposits throughout the site. Thickness of loess

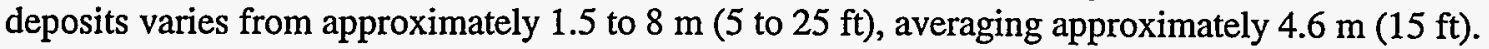

The local groundwater flow system at the Paducah Site contains four major components: the McNairy flow system, the regional gravel aquifer (RGA), the upper continental recharge system (UCRS), and the terrace gravels.

- The McNairy flow system consists of interbedded and interlensing sand, silt, and clay of the McNairy Formation. Sand facies account for 40 to $50 \%$ of the total formation thickness of approximately $69 \mathrm{~m}(225 \mathrm{ft})$.

- The RGA consists of sand and gravel facies in the lower continental deposits, gravel and coarse sand portions of the upper McNairy that are directly adjacent to the lower continental deposits, coarse-grained sediments at the base of the upper continental deposits, and alluvium adjacent to the Ohio River. These deposits have an average thickness of $9 \mathrm{~m}(30 \mathrm{ft})$ and range up to $15 \mathrm{~m}$ $(50 \mathrm{ft}$ ) along an axis that trends east-west through the site. The RGA is the uppermost and primary aquifer, formerly used by private residences north of the Paducah Site.

- The UCRS consists mainly of clayey silt with interbedded sand and gravel in the upper continental deposits. The system is so named because of its characteristic recharge to the RGA.

- The terrace gravels consist of shallow Pliocene gravel deposits in the southern portion of the plant site. These deposits usually lack sufficient thickness and saturation to constitute an aquifer but may be an important source of groundwater recharge to the RGA. 
Groundwater flow originates south of the Paducah Site within Eocene sands and the terrace gravels. Groundwater within the terrace gravels either discharges to local streams or recharges the RGA, although the flow regime of the terrace gravels is not fully understood. Groundwater flow through the UCRS is ultimately downward, also recharging the RGA. From the plant site, groundwater flows generally northward in the RGA toward the Ohio River, the local base level for the system.

\section{Uses of Groundwater in the Vicinity}

The West Kentucky Wildlife Management Area and some lightly populated farmlands are in the immediate vicinity of the Paducah Site. Homes are sparsely located along rural roads in the vicinity of the site. Three communities lie within 3.2 kilometers ( 2 miles) of the plant: Magruder Village to the southwest and Grahamville and Heath to the east.

Both groundwater and surface water sources have been used for water supply to residents and industries in the plant area. Wells in the area are screened at depths ranging from 4.6 to $75 \mathrm{~m}$ (15 to $245 \mathrm{ft}$ ). Most of these wells are believed to be screened in the RGA. The Paducah Site continues to provide municipal water to all residents within the area of groundwater contamination from the site. The residents' wells have been turned over to the Environmental Restoration Division for sampling. Residential wells that are no longer sampled have been locked and capped.

\section{Groundwater Monitoring Program}

The primary objectives of groundwater monitoring at the Paducah Site are to detect as early as possible any contamination resulting from past and present land disposal of wastes and to provide the basis for developing groundwater quality assessments if contamination is detected. Additional objectives outlined in DOE Order 5400.1, General Environmental Protection Program, require that groundwater monitoring at all DOE facilities "... . determine and document the effects of operations on groundwater quality and quantity." The order specifically requires groundwater monitoring to be conducted on-site and in the vicinity of DOE facilities to accomplish the following:

- obtain data to determine baseline conditions of groundwater quality and quantity;

- demonstrate compliance with, and implementation of, all applicable regulations and DOE orders;

- $\quad$ provide data to permit early detection of groundwater pollution or contamination;

- $\quad$ provide a reporting mechanism for detected groundwater pollution or contamination;

- identify existing and potential groundwater contamination sources and maintain surveillance of these sources; and

- provide data for making decisions about land disposal practices and the management and protection of groundwater resources.

These objectives are outlined in three documents relating to groundwater monitoring: Paducah Gaseous Diffusion Plant Groundwater Protection Program Management Plan (Miller and Douthitt 1993); Groundwater Monitoring Plan for the Paducah Gaseous Diffusion Plant, Paducah, Kentucky (Early, Sigmon, and Williams 1989); and the Environmental Monitoring Plan (LMES 1995).

The Groundwater Protection Program Management Plan identifies specific responsibilities, assigns responsibility to various entities within the plant, and coordinates Environmental Restoration and 
Environmental Management initiatives. The Groundwater Monitoring Plan provides a comprehensive blueprint for DOE to follow at each facility that targets the environmental protection of groundwater.

\section{Groundwater Monitoring}

Groundwater monitoring at the Paducah Site is specified in the Addendum to the Sampling and Analysis Plan (Clausen, Millay, and Jones 1995). The addendum, updated annually as characterization continues, schedules sampling efforts for more than 200 monitoring wells, residential wells, and Tennessee Valley Authority wells in accordance with DOE orders and federal, state, and local requirements. Well sampling includes several different monitoring programs, which are described below.

\section{Underground Storage Tank Monitoring}

In 1989, petroleum hydrocarbons were discovered in a plant monitoring well northeast of the C-750 garage. Two underground fuel tanks at the garage were tested and found to be leaking. A site investigation confirmed the presence of soil and groundwater contamination near the garage, possibly caused by releases from the underground storage tanks (USTs). The 2 USTs were removed, and 13 monitoring wells (MWs) were installed. Results from "Site Investigation of the Underground Storage Tanks at the C-200, C-710, and C-750 Buildings" (CDM 1992) indicate that groundwater contamination from leaking USTs is limited to the UCRS, which is not considered to be an aquifer and is not a source of drinking water in the Paducah area. Currently, MW207 (UCRS) and MWs 212-219 (UCRS), along with MW68 (RGA), MW69 (UCRS), MW71 (RGA), and MW96 (UCRS), are used to monitor the vicinity of the UST locations.

\section{RCRA Interim Status and Permit Monitoring Programs}

At present, the only hazardous waste facility at the Paducah Site that requires groundwater monitoring is the C-404 landfill. This landfill was operated until 1986, when hazardous waste was discovered at the facility. The landfill was covered with a Resource Conservation and Recovery Act (RCRA)-compliant clay cap and was certified closed as a hazardous waste landfill in 1987. The landfill is now monitored under post-closure monitoring requirements.

According to EPA Hazardous Waste Permit KY8-890-008-982, 14 wells, MWs 84-95, 226, and 227, monitor groundwater quality of the UCRS and the underlying RGA during the required post-closure care. Monitoring had previously been required on a quarterly basis. However, in 1994, monitoring at the landfill was changed from assessment monitoring to detection monitoring, which is required semiannually.

\section{State Solid Waste Disposal Regulations}

Postclosure groundwater monitoring continues to exist for the C-746-S Residential Landfill. The landfill stopped receiving solid waste before July 1,1995 , and was certified closed on October 31,1995 , by an independent engineering firm. The groundwater monitoring system for the C-746-S Residential Landfill also encompasses the C-746-T Inert Landfill which was certified closed in November 1992. The C-746-T Inert Landfill has fulfilled its two years of postclosure environmental monitoring and maintenance requirements and is awaiting final closure approval from KDWM. 
The groundwater monitoring system for the above mentioned facilities consists of (3) upgradiant and (10) downgradient wells. The system is designed to monitor both the upper and lower portions of the RGA. Upgradient wells are recognized as 181,220 , and 267 while downgradient wells are recognized as 179 , 221 thru 225, and 263 thru 266. Well 225 is monitored for static water level only. The monitoring wells are sampled quarterly and in accordance with 401 Kentucky Administrative Regulations (KAR) 48:300. The analytes are dictated by a KDWM approved solid waste landfill permit modification.

Presently, a new solid waste landfill is being constructed at the Paducah Site and is identified as the C-746-U Contained Landfill.. Solid waste regulations require groundwater characterization of the upper most aquifer down to and including the lowest aquifer that may be affected by the facility. The chemical description shall include two (2) samples of groundwater from the site before waste placement for the parameters listed in 401 KAR 48:300 Section 10.

The groundwater monitoring system for this facility is described in Section 25 of the landfill's Technical Application for a solid waste landfill permit. The groundwater monitoring network consists of (10) wells located in five two-well clusters. One well cluster (MW 276, MW 277) is located hydraulically upgradient of the facility and four well clusters (MW 268 thru MW 275) are located hydraulically downgradient. The system is designed to monitor both the upper and lower portions of the RGA.

Groundwater characterization data for the C-746-U Contained Landfill facility was submitted to the KDWM during December, 1995. Samples were collected during January 1995 (low-water table conditions) and May 1995 (high-water table conditions) with select parameters also collected during September 1995 as part of the low-water table conditions.

\section{CERCLAACO Monitoring (Off-Site Wells)}

The ACO between DOE and EPA under CERCLA legislation requires monthly sampling of potentially affected off-site wells and plant well MW66 (RGA) for TCE, ${ }^{99} \mathrm{Tc}$, and gross alpha and beta activity. During 1995, residential wells R2, R5, R18, R293, R294, and R302 were sampled monthly; R4, R6, R10, R26, R40, R253, and R254 were sampled quarterly; and R9, R12-R14, R19-21, R23, R31, R39, R43, R72, R82-84, R90, and R381 were sampled semiannually. As stated previously, the hydrologic unit in which residential wells are screened is uncertain; however, most are believed to be RGA wells.

\section{Environmental Surveillance Monitoring}

The Groundwater Surveillance Plan for the Paducah Gaseous Diffusion Plant (SAIC 1993b) describes monitoring of exit pathways along the northern boundary of the DOE reservation. Environmental surveillance also provides information on background, DNAPLs, and ongoing geochemical evaluation. The wells associated with environmental surveillance are:

- $\quad$ For exit-pathway monitoring-MWs 64, 127, 128, 138, 149, 154, 160, 162, 164, 166, 167, 170, $171,172,174,176,177,180,182,184,189,190,192,195,198$, and 204 for the UCRS; MWs 63 , $65,98,99,106,123-126,132,134,135,137,139,146-148,150,158,159,161,163,165,168$, $169,173,175,178,179,188,191,193,197,203,205,206,255-258,260-262,300-303$, and 325330 for the RGA; and MWs 121 and 133 for the McNairy flow system. 
- For background monitoring-MWs 104, 129-131, and 143 in the UCRS; MWs 103, 141, 142, 151 , and 199 for the RGA; MWs 102, 120, and 140 in the McNairy flow system; and MW196 in the terrace gravels.

- For DNAPL monitoring-MWs 157 and 160 for the UCRS and MW155 for the RGA.

- For geochemical evaluations-MWs 153, 157, 186, and 187 for the UCRS and MWs 20, 66, 144, $145,152,155,156,185$, and 200-202 for the RGA.

\section{Environmental Restoration Activities}

\section{Groundwater Integrator Unit}

Recent investigations have led to the discovery of several separate groundwater plumes, which commingle and appear to contribute to one of two off-site groundwater plumes: the northwest plume and the northeast plume, see Fig. 9.11. Primary contaminants of these plumes are TCE in the northeast plume and TCE and ${ }^{99} \mathrm{Tc}$ in the northwest plume. The contaminated groundwater is grouped within a groundwater integrator unit for investigation and remediation. Groundwater is grouped this way because (1) the contamination is isolated from surface sources, (2) sources of contamination are uncertain, (3) the groundwater underlies many waste area groups (WAGs), and (4) the groundwater will be remediated independent of other solid waste management units (SWMUs), in part because of the presence of DNAPLs.

An interim action record of decision for the northwest plume was agreed upon in 1993 by the EPA, the Commonwealth of Kentucky, and DOE. The decision is proposed as a first phase of remedial action for groundwater at the site and is not intended as a final action. Operations began at the Northwest Treatment Facility in August 1995.

To fulfill the Interim Corrective Measures Work Plan for the Northeast Plume (MMES 1994b), an investigation took place in summer 1994. From data derived from this investigation, an interim action record of decision for the northeast plume was agreed upon in June 1995.

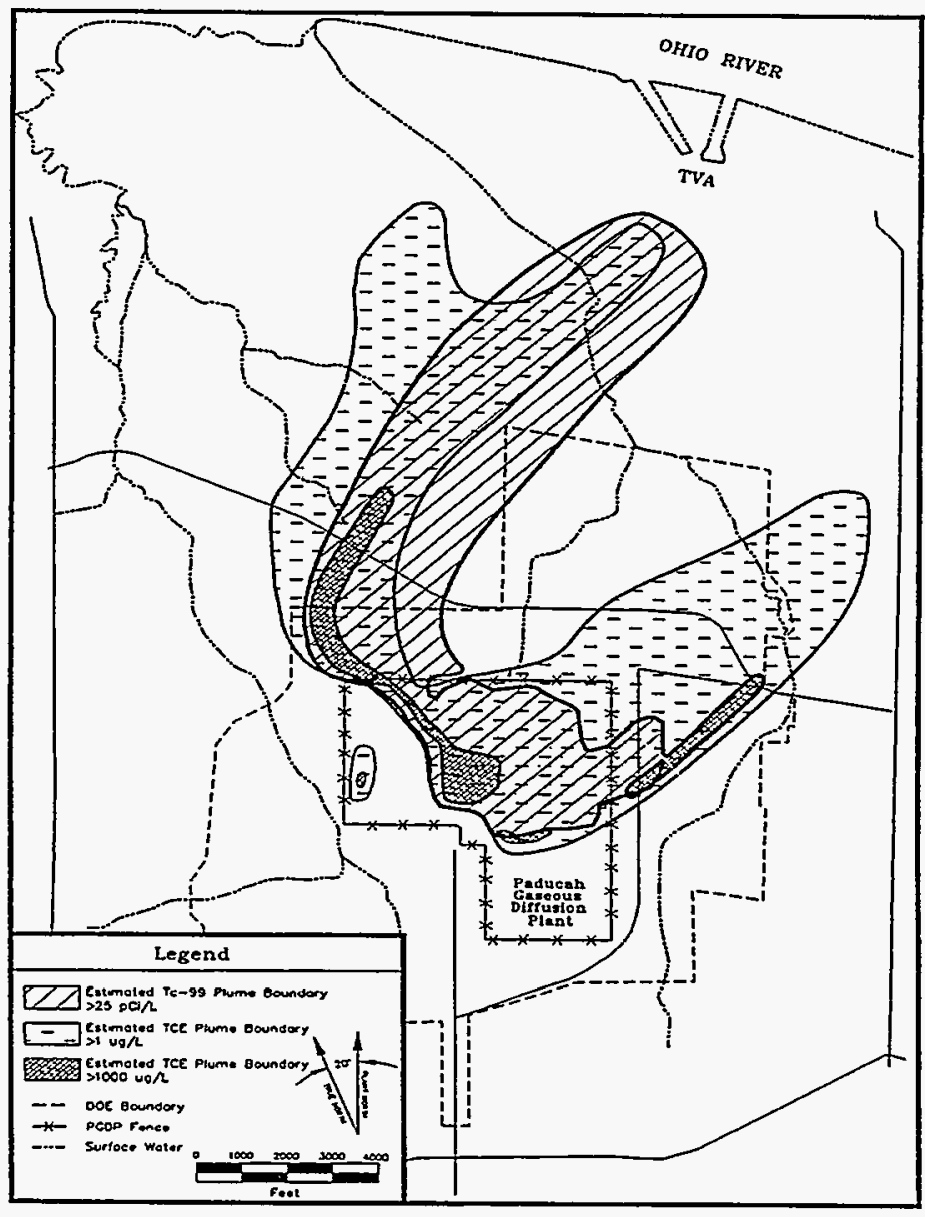

Figure 9.11 Off-site extension of groundwater plumes. 


\section{Interim Action Record of Decision for the Northwest Plume}

The EPA approved an interim action record of decision to hydraulically contain off-site migration of the northwest plume. This action is a first phase of remedial action for groundwater at the Paducah Site. Two extraction wells near a source of the northwest plume and two additional extraction wells farther north, near the centroid of the plume, were installed. Each set of extraction wells is surrounded by a monitoring well network. The network is used for monitoring groundwater quality and water levels to determine the effectiveness of the interim action. The groundwater extraction system recovers TCE- and ${ }^{99} \mathrm{Tc}-$ contaminated groundwater from the RGA northwest of the plant boundary. Water extracted from the wells is treated by air stripping for the TCE and by ion exchange to remove the ${ }^{99} \mathrm{Tc}$ before being discharged into a KPDES surface water outfall. Between the beginning of operations on August 28, 1995 and January 31, 1996 , almost $37,000,000$ gallons of water have been treated, resulting in recovery of approximately 20 gallons of TCE and 0.2 curies of ${ }^{99} \mathrm{Tc}$.

Due to the nature the groundwater extraction system, only long-term monitoring will show how effective the system is. Data gathered in 1995 is useful for establishing baseline contaminant concentrations and early effects of the pumping on the local hydraulic gradients.

\section{Interim Action Record of Decision for the Northeast Plume}

After completion of the Northeast Plume Investigation in October 1994, an interim action record of decision was developed. This Record of Decision was approved by the EPA in June 1995. The interim action calls for hydraulic containment of a high concentration $(>1000 \mu \mathrm{g} / \mathrm{L})$ volume of TCE near the south edge of the plume using groundwater extraction wells. Two wells will be installed near the tip of the high concentration plume. The recovered TCE-contaminated water will be pumped to the Paducah Gaseous Diffusion Plant (PGDP) cooling towers which will serve as air strippers to remove the TCE. The treated water will then become part of the plant's process water system.

\section{Lasagna $^{\circledR}$ Demonstration}

A research consortium (consisting of Monsanto, Du Pont, and General Electric), in conjunction with DOE, begun work to demonstrate the use of electroosmosis in combination with in situ remediation zones to remediate low permeability soils. Field equipment was installed in November 1994, see Figure 9.12, and Phase I of the demonstration operated between January and June 1995. The project was considered successful because the technology removed $98 \%$ of the TCE, resulting in the first remediation of contaminated soil at the Paducah Site.

\section{Residential Well Locking and Capping}

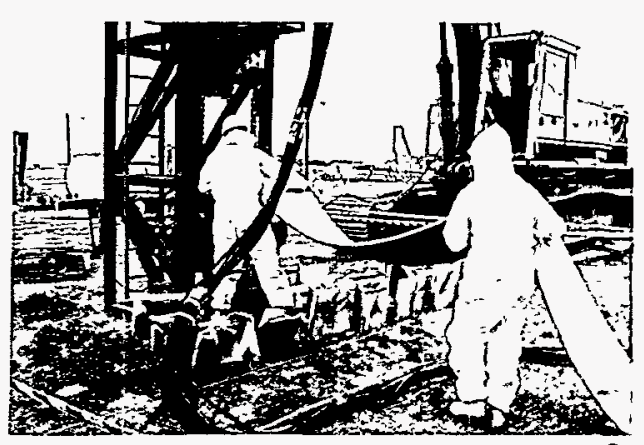

Figure 9.12 Installation of the Lasagna ${ }^{\circ}$ Demonstration

From May 15 through June 30, 1995, private wells belonging to residents being furnished public water by DOE were capped and locked to prevent inadvertent contact with contaminated groundwater. A total of 55 wells were modified during this project. Nineteen of the wells remain part of the off-site groundwater monitoring network. 


\section{Site Evaluation For Outfall 010, 011, and 012 Areas}

A field sampling investigation took place September through November near KPDES Outfalls 011 and 012. The purpose of the investigation was to fill data gaps to determine necessary response actions to prevent continued releases of polychlorinated biphenyls (PCBs) and TCE into the above outfalls. The sampling strategy focused on ditch sediments, soils, and groundwater within the UCRS and terrace gravels. Geophysical surveys were conducted prior to intrusive sampling to determine buried metal drums or evidence of landfilling.

Results from the investigation showed a shallow groundwater TCE plume migrating away from Outfall 011, northward. A final report was issued in December 1995.

\section{Applicable Mlonitoring Standards}

Table 9.1 lists the analysis parameters and regulatory limits or guidelines for groundwater monitoring wells. This table also shows regularly sampled wells that met or exceeded the reference value at least once during 1995.

\section{Groundwater Monitoring Results}

Groundwater monitoring results from all sampling efforts conducted by the Paducah Site are compiled in the Environmental Information Management System (EIMS) data base. A complete listing of analytical results are available upon request from the Energy Systems Public Affairs Department.

Table 9.1 Applicable groundwater monitoring 1995 results at Paducah Site

\begin{tabular}{|c|c|c|c|}
\hline Parameter & $\begin{array}{l}\text { Applicable } \\
\text { Value }\end{array}$ & Reference & Wells exceeding reference value at least once in 1995 \\
\hline Aluminum & $0.05-0.2 \mathrm{mg} / \mathrm{L}$ & a & $\begin{array}{l}\text { MW66, MW181, MW220, MW222, MW223, MW233, } \\
\text { MW235, MW237-242, MW244-250, MW264, MW272, } \\
\text { MW274-275, MW300, MW302, MW303 }\end{array}$ \\
\hline Antimony & $0.006 \mathrm{mg} / \mathrm{L}$ & b & MW223, MW247 \\
\hline Arsenic & $0.05 \mathrm{mg} / \mathrm{L}$ & b & MW186, MW227, R186 \\
\hline Barium & $2.0 \mathrm{mg} / \mathrm{L}$ & b & MW257, MW258 \\
\hline Beryllium & $0.004 \mathrm{mg} / \mathrm{L}$ & b & $\mathrm{MW} 300, \mathrm{R} 172, \mathrm{R} 173$ \\
\hline Cadmium & $0.005 \mathrm{mg} / \mathrm{L}$ & b & None \\
\hline Chloride & $250 \mathrm{mg} / \mathrm{L}$ & $\mathbf{a}$ & MW186, MW261 \\
\hline Chromium & $0.1 \mathrm{mg} / \mathrm{L}$ & b & $\begin{array}{l}\text { MW63, MW71, MW91, MW124, MW 148, MW159, } \\
\text { MW168, MW175, MW180, MW181, MW185, MW205, } \\
\text { MW206, MW226, MW227, MW237, MW263 }\end{array}$ \\
\hline Color (of Water) & 15 Units & a & None \\
\hline
\end{tabular}




\begin{tabular}{|c|c|c|c|}
\hline Parameter & $\begin{array}{l}\text { Applicable } \\
\text { Value }\end{array}$ & Reference & Wells exceeding reference value at least once in 1995 \\
\hline Copper & $1.3 \mathrm{mg} / \mathrm{L}$ & a & R4 \\
\hline Fluoride & $4.0 \mathrm{mg} / \mathrm{L}$ & $\mathrm{b}$ & MW178 \\
\hline Iron & $0.30 \mathrm{mg} / \mathrm{L}$ & a & $\begin{array}{l}\text { MW20, MW63, MW66, MW71, MW96, MW98, MW99, } \\
\text { MW102, MW103, MW106, MW120-124, MW128, } \\
\text { MW134, MW135, MW145-146, MW148, MW150, } \\
\text { MW152, MW156-157, MW159, MW161, MW163, } \\
\text { MW168-169, MW173-175, MW180-182, MW185-187, } \\
\text { MW192-93, MW-197, MW201-203, MW205-206, } \\
\text { MW220, MW222-223, MW233-242, MW244-250, } \\
\text { MW255-258, MW260-266, MW269-270, MW272-276, } \\
\text { MW300-303, MW306-311, MW317, MW325, MW328- } \\
\text { 330, R2, R4, R5 }\end{array}$ \\
\hline Lead & $0.15 \mathrm{mg} / \mathrm{L}$ & $\mathrm{b}$ & MW250, MW327 \\
\hline Manganese & $0.05 \mathrm{mg} / \mathrm{L}$ & a & $\begin{array}{l}\text { MW20, MW96, MW98, MW102, MW120-124, MW133, } \\
\text { MW134, MW156, MW157, MW159, MW161, MW163, } \\
\text { MW168, MW173-174, MW178, MW180-182, MW185- } \\
\text { 187, MW193, MW197, MW201-203, MW205, MW220, } \\
\text { MW223, MW233, MW237-250, MW255-258, MW260- } \\
\text { 265, MW267, MW269-270, MW272-273, MW277, } \\
\text { MW300-303, MW309-311, MW317, MW325-330, R4 }\end{array}$ \\
\hline Mercury & $0.002 \mathrm{mg} / \mathrm{L}$ & $\mathrm{b}$ & None \\
\hline Nickel & $0.1 \mathrm{mg} / \mathrm{L}$ & $\mathrm{b}$ & None \\
\hline Nitrate as nitrogen & $10 \mathrm{mg} / \mathrm{L}$ & $\mathrm{b}$ & MW236, MW240, MW243, MW248, MW261 \\
\hline $\mathrm{pH}$ & $6.5-8.5 \mathrm{SU}^{\mathrm{b}}$ & a & $\begin{array}{l}\text { MW108, MW121, MW239, R2, R4-6, R9, R10, R12-14, } \\
\text { R19, R26, R39, R40, R90, R253, R254, R381 }\end{array}$ \\
\hline Selenium & $0.05 \mathrm{mg} / \mathrm{L}$ & $\mathrm{b}$ & None \\
\hline Silver & $0.05 \mathrm{mg} / \mathrm{L}$ & b & MW135, MW152 \\
\hline Sulfate & $250 \mathrm{mg} / \mathrm{L}$ & a & MW174, MW246, MW300-301, MW303 \\
\hline Thallium & $0.002 \mathrm{mg} / \mathrm{L}$ & b & MW18, MW102, MW129, MW186 \\
\hline Total dissolved solids & $500 \mathrm{mg} / \mathrm{L}$ & a & $\begin{array}{l}\text { MW125, MW157, MW174, MW179. MW186-187, } \\
\text { MW261, MW300-303, MW329 }\end{array}$ \\
\hline Water turbidity & $5 \mathrm{NTU}^{\mathrm{c}}$ & $\mathrm{b}$ & $\begin{array}{l}\text { MW20, MW63, MW66, MW71, MW96, MW98, MW102, } \\
\text { MW106, MW108, MW120-124, MW128, MW134-135, } \\
\text { MW148, MW156-157, MW159, MW161, MW168-169, } \\
\text { MW173-175, MW180-181, MW185-187, MW192-194, } \\
\text { MW197, MW200-203, MW205-206, MW220, MW222- } \\
\text { 223, MW233, MW235-236, MW238-242, MW244-250, } \\
\text { MW255-258, MW260-266, MW300-303, MW306-311, } \\
\text { MW317, MW328-330, R4 }\end{array}$ \\
\hline Zinc & $5.0 \mathrm{mg} / \mathrm{L}$ & a & R5 \\
\hline Benzene & $0.005 \mathrm{mg} / \mathrm{L}$ & $\mathrm{b}$ & None \\
\hline
\end{tabular}




\begin{tabular}{|c|c|c|c|}
\hline Parameter & $\begin{array}{l}\text { Applicable } \\
\text { Value }\end{array}$ & Reference & Wells exceeding reference value at least once in 1995 \\
\hline Carbon tetrachloride & $0.005 \mathrm{mg} / \mathrm{L}$ & b & None \\
\hline 1,2-Dichloroethane & $0.005 \mathrm{mg} / \mathrm{L}$ & b & None \\
\hline $\begin{array}{l}\text { cis-1,2- } \\
\text { Dichloroethene }\end{array}$ & $0.07 \mathrm{mg} / \mathrm{L}$ & b & MW186, MW300 \\
\hline $\begin{array}{l}\text { trans-1,2- } \\
\text { Dichloroethene }\end{array}$ & $0.1 \mathrm{mg} / \mathrm{L}$ & b & MW145 \\
\hline 1.1-Dichloroethene & $0.007 \mathrm{mg} / \mathrm{L}$ & b & MW300 \\
\hline Ethylbenzene & $0.7 \mathrm{mg} / \mathrm{L}$ & b & MW96 \\
\hline $\begin{array}{l}\text { Polychlorinated } \\
\text { biphenyls }\end{array}$ & $0.0005 \mathrm{mg} / \mathrm{L}$ & $b$ & None \\
\hline Tetrachloroethene & $0.005 \mathrm{mg} / \mathrm{L}$ & $\mathrm{b}$ & None \\
\hline Toluene & $1 \mathrm{mg} / \mathrm{L}$ & $\mathrm{b}$ & None \\
\hline 1,1,2-Trichloroethane & $0.005 \mathrm{mg} / \mathrm{L}$ & $b$ & None \\
\hline Trichloroethene & $0.005 \mathrm{mg} / \mathrm{L}$ & $b$ & $\begin{array}{l}\text { MW20, MW66, MW71, MW88, MW91, MW94, MW108, } \\
\text { MW124, MW126, MW134, MW145, MW148, MW155- } \\
\text { 157, MW159, MW161, MW163, MW168, MW175, } \\
\text { MW178, MW185-188, MW193, MW197, MW201-203, } \\
\text { MW226, MW233-236, MW238, MW240-245, MW248- } \\
\text { 250, MW255-258, MW260-263, MW276-277, MW300, } \\
\text { MW325-326, R2, R4, R424, R432 }\end{array}$ \\
\hline Vinyl chloride & $0.002 \mathrm{mg} / \mathrm{L}$ & b & MW186 \\
\hline Xylene & $10 \mathrm{mg} / \mathrm{L}$ & $b$ & None \\
\hline Neptunium-237 & $1.2 \mathrm{pCi} / \mathrm{L}$ & c & None \\
\hline Plutonium-239 & $1.2 \mathrm{pCi} / \mathrm{L}$ & c & None \\
\hline Radon-222 & $300 \mathrm{pCi} / \mathrm{L}$ & d & $\begin{array}{l}\text { MW63, MW65-66, MW71, MW98-99, MW103, MW106, } \\
\text { MW123-126, MW128, MW135-137, MW139, MW142, } \\
\text { MW146, MW148, MW150, MW152, MW155-157, } \\
\text { MW159, MW163, MW165, MW168-169, MW173-174, } \\
\text { MW178, MW180, MW182, MW185, MW187-188, } \\
\text { MW191, MW193-194, MW197, MW200-203, MW233- } \\
\text { 236, MW238-242, MW245-246, MW248-249, MW255- } \\
\text { 262, MW302-303, MW305, MW307, MW309-311, } \\
\text { MW325-330, R2, R5, R9, R90, R294, R302, R381 }\end{array}$ \\
\hline Radium-226 & $20 \mathrm{pCi} / \mathrm{L}$ & $d$ & None \\
\hline Technetium-99 & $3790 \mathrm{pCi} / \mathrm{L}$ & d & MW243, MW261 \\
\hline Thorium-230 & $12 \mathrm{pCi} / \mathrm{L}$ & c & None \\
\hline Uranium & $0.02 \mathrm{mg} / \mathrm{L}$ & $\mathrm{d}$ & MW95, MW182, MW303 \\
\hline Gross alpha & $15 \mathrm{pCi} / \mathrm{L}$ & b & $\begin{array}{l}\text { MW66, MW182, MW233, MW236, MW243, MW246, } \\
\text { MW248, MW250, MW300-301, MW303, R2 }\end{array}$ \\
\hline
\end{tabular}




\begin{tabular}{lccc}
\hline Parameter & $\begin{array}{c}\text { Applicable } \\
\text { Value }\end{array}$ & Reference & Wells exceeding reference value at least once in 1995 \\
\hline Gross beta & $3790 \mathrm{pCi} / \mathrm{L}$ & d & MW261, MW262 \\
\hline
\end{tabular}

a. 40 CFR Pt. 143. Safe Drinking Water Act-National Secondary Drinking Water Regulations, as amended.

b. 40 CFR Pt. 141. Safe Drinking Water Act-National Primary Drinking Water Regulations, as amended.

c. Four percent of derived concentration guidelines for air and water (4 mrem/year), DOE Order 5400.5, Radiatión Protection of the Public and the Environment.

d. Proposed maximum contaminant level in 56 Federal Register, July 18, 1991, National Primary Drinking Water Regulations for Radionuclides in Drinking Water. 


\title{
10. Quality Assurance
}

\begin{abstract}
The Paducah Site maintains a quality assurance/quality control program to verify the integrity of data generated within the environmental monitoring program. Monitoring and sampling organizations at Paducah select sampling methods, instruments, locations, schedules, and other sampling and monitoring criteria based on applicable guidelines from various established authorities and by participation from compliance and analytical organizations at the site. Chain-of-custody procedures are followed and documented from the point of sampling until analysis or disposal of the sample.
\end{abstract}

\section{Introduction}

The Paducah Site maintains a quality assurance/quality control (QA/QC) program to verify the integrity of data generated within the environmental monitoring program. Each aspect of the monitoring program, from sample collection to data reporting, must address QA, QC, and quality assessment standards. Requirements and guidelines for the QA/QC program at the Paducah Site are established by Department of Energy (DOE) Order 5700.6C, Quality Assurance; state and federal regulations; and documentation from the Environmental Protection Agency (EPA), the American National Standards Institute, the American Society of Mechanical Engineers, and the American Society for Quality Control. The QA/QC program specifies organizational, inspective, and programmatic elements to control equipment, design, documents, nonconformances, and records. Emphasis is placed on planning, audits, records, and corrective actions.

Through a memorandum of understanding, United States Enrichment Corporation (USEC) through Lockheed Martin Utility Services (Utility Services) supplies DOE with the personnel to support environmental sampling activities and the quality requirements for monitoring programs. The LMES PGDP Groundwater Program Quality Assurance Plan, (Blewett, 1996) provides a description of the quality elements regarding groundwater. The Utility Services Environmental Monitoring Group follows the Quality Assurance Plan for the Environmental Monitoring Department (Jett 1992). These documents define the relationship of each element of the environmental monitoring program to key QA/QC requirements. Training requirements, sample custody, procedures, instrument calibration, and maintenance are a few of the subjects discussed in each document. The Energy Systems Quality Services Organization and the Utility Services Environmental Management Group perform a variety of functions critical to the environmental monitoring program. Included in the responsibilities of these groups are developing data quality objectives, conducting surveillances, reporting problems, and validating data. Other roles of the section include preparing procedures and writing and reviewing QA plans.

\section{Field Sampling and Monitoring}

\section{Basic Concepts and Practices}

From the point of conception of any sampling program, QA/QC plays an important role. Each monitoring or sampling organization plans a project, sets objectives, identifies responsibilities, and selects sampling methods and the appropriate sampling instruments or devices according to use and cleaning practices recommended by the American Society for Testing and Materials, the EPA, or other established 
authorities. The number of samples, location of sampling sites, sampling methods, sampling schedules, and coordination of sampling and analytical resources to meet critical completion times must be decided. The rationale for these and other decisions is mainly the responsibility of the sampling organization, which receives input from compliance and analytical organizations. Sampling plans and field documentation are prepared as needed.

Chain-of-custody documentation is maintained from the point of sampling, and samples are properly protected until they are placed in the custody of analytical laboratory control programs. In the laboratory, chain-of-custody procedures are followed until a sample is analyzed. For hazardous waste samples, chain-of-custody procedures are maintained to the point of sample disposal. The performance of field analytical procedures is documented using EPA-approved methods when available.

The quality control program for both groundwater and environmental monitoring activities specifies a target rate of $5 \%$ on field samples. Table 10.1 shows the types of QA/QC samples used and what areas are controlled. Monitoring QA/QC samples are chosen so that the combination of samples meets the targeted QA/QC rate. The sample Table 10.1 Types of QAVC samples and controlled areas combination varies with the activity performed.

\section{Analytical Quality Assurance}

The analytical laboratories at the Paducah Site continue a long tradition of QA. Such terms as sound methodology, safe practices, analytical recovery, and QC are well defined. Also well established is the use of statistical methods to establish precision, accuracy, lowest concentration reported, and minimum detection level. Since the beginning of operations at the site, the analytical laboratories have been involved in the handling and analysis of materials of high purity and hazardous materials, for which strict accountability is required. QA is, therefore, a daily responsibility.

After receiving samples from the sampling group or the sample transporter, the laboratory custodian assumes responsibility for proper protection and handling of the samples. Using guidance from the EPA, the laboratories document the steps in handling, analysis, and approval of results. The performance of all analytical procedures is documented using EPA-approved methods when they are available.

A key feature in analytical QA is QC. The Paducah Site participates in programs that are internal to the laboratory (i.e., internal controls), and external to the plant (i.e., independent controls). 


\section{Internal Quality Control}

All analytical activities are supported by the use of standard, or reference, materials. The compositions of these materials are well known and are used in the calibration of instruments, method standardization, spike additions for recovery testing, and other practices. Certified standards from the National Institute of Standards and Technology, the EPA, or other DOE laboratories are often used in such work.

These internal programs are the mainstay of analytical QC and the basis for ensuring reliable results on a daily basis and between batches. The total effort in these programs is at least $10 \%$ of the total laboratory effort (according to EPA expectations) and probably reaches $20 \%$ for some activities.

Internal QA and QC programs have become major factors in environmental analysis procedures because of the low levels of pollutants measured and the relationships of these measured values to regulatory limits. These $\mathrm{QC}$ programs also provide for laboratory analyst training and qualification in the many procedures used. Daily QC data are stored in a retrievable manner so that they can be related to the analytical results they support.

\section{Independent Quality Control}

The Paducah Site is directed by DOE and EPA regulators to participate in independent QC programs. The site also participates in voluntary independent programs to improve analytical QC. These programs generate data that are readily recognizable as objective measures, allowing participating laboratories and government agencies a periodic review of their performance. Results that exceed acceptable limits are investigated and documented according to formal procedures. Although participation in certain programs is mandated, the degree of participation is voluntary so that each laboratory can select parameters of particular interest to that facility. These programs are conducted by the EPA, DOE, and commercial laboratories. The Utility Services Quality Support Section coordinates and evaluates the results of the independent QC programs, which are discussed in the following.

\section{EPA Discharge Monitoring Report Quality Assurance Program}

The EPA conducts a national QA program in support of the National Pollutant Discharge Elimination System (NPDES) program. All holders of major NPDES permits are required to participate. The EPA furnishes QC samples annually and evaluates the results. The Commonwealth of Kentucky monitors performance in this program. The Paducah Site is required to analyze those parameters on its Kentucky Pollutant Discharge Elimination System (KPDES) permit included in the Discharge Monitoring Report (DMR) QA Program. Other parameters may be analyzed on a voluntary basis for documentation or method checking. The statistical data for the 1995 analyses has not been received.

\section{Proficiency Environmental Testing Program}

The Paducah Site participates in the Proficiency Environmental Testing (PET) Program, a voluntary external measurement control program using samples purchased from Analytical Products Group, Inc., a commercial supplier. Samples at two concentration levels are analyzed bimonthly and reported to Analytical Products Group, Inc.. An evaluation report is received in approximately three weeks. Most samples are evaluated by comparing (in standard deviations) the reported value to the mean of the 
reporting laboratories. Samples for dissolved and suspended solids are compared with the average percent of recovery in the same way. Performance evaluation is derived using the same criteria as those in the DMR QA Program. The Quality Support Section maintains control charts on these analyses.

Measurements that have unacceptable recoveries of more than 2.58 standard deviations from the mean are investigated to detect the cause. Of 787 measurements made in 1995, 21 'were deemed not acceptable.

\section{Proficiency Analytical Testing Program}

Paducah also participates in the Proficiency Analytical Testing (PAT) Program, an external measurement control program run by the National Institute for Occupational Safety and Health. This program targets industrial hygiene analyses but is also applicable to environmental monitoring because the concerns in both fields overlap. Of 100 measurements made in 1995, four were deemed not acceptable. The laboratory maintained a proficient rating for 1995.

\section{DOE Environmental Measurements Laboratory Quality Assessment Program}

The Paducah Site participated in the Environmental Measurements Laboratory QA Program as required by DOE Order 5400.1, General Environmental Protection Program. The performance evaluation for this program is determined by using the three ratio ranges given in the Environmental Measurements Laboratory QA report to decide "acceptable," "marginal," or "not acceptable" results. Of 31 measurements made in 1995, one was deemed unacceptable.

\section{EPA Intercomparison Radionuclide Control Program}

The EPA Intercomparison Radionuclide Control Program is administered by the EPA Environmental Monitoring System Laboratory at Las Vegas (EMSL-LV). Samples include water and air filters. The EMSL-LV Program calculates a normalized standard deviation for each laboratory based on all reported results. By their criteria, any reported value above three standard deviations is considered unacceptable. Of the 18 measurements made in 1995, two were deemed unacceptable.

\section{Mixed Analyte Performance Evaluation Program}

The Paducah Site participates in the Mixed Analyte Performance Program (MAPEP), a measurement control program administered by the Department of Energy, Radiological and Environmental Sciences Laboratory. This program addresses issues associated with the identification of mixed waste analysis. Of the 44 measurements made in 1995, 4 were deemed unacceptable.

\section{Real World Soil and Wastewater Program}

The Paducah Site participated in the Real World Wastewater and Soil Programs, a voluntary measurement control program purchased from Analytical Products Group, Inc., a commercial supplier. These programs were developed to evaluate a laboratory's performance on natural sample matrix. Of the 100 measurements for the Real World Wastewater Program made in 1995, 6 were deemed unacceptable. For the Real World Soil Program, there were 50 measurements and 10 were determined to be unacceptable. 


\section{Water Supply Performance Evaluation Study and Water Pollution Performance Evaluation} Study

The Paducah Site participates in the Water Supply Performance Evaluation Study (WS) and the Water Pollution Performance Evaluation Study (WP) administrated by Environmental Protection Agency. These programs are used to assess the laboratories that support the drinking water (WS) and wastewater (WP) certification programs. Out of the 82 measurements for the WS program made in 1995,7 were deemed unacceptable. Out of the 28 measurements for the WP program made in 1995,14 were deemed unacceptable.

Figure 10.1 shows the Paducah Site analytical laboratory's percentage of acceptable results for all the independent quality control programs participated in during 1995.

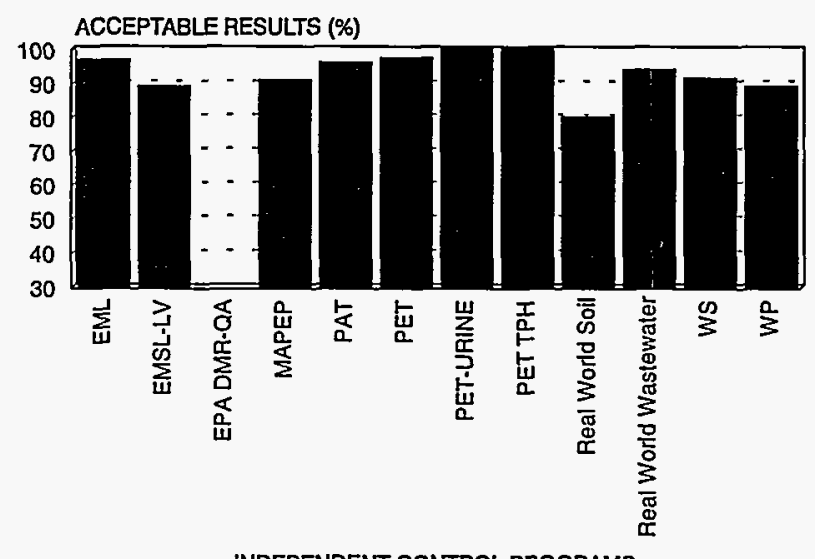

INDEPENDENT CONTROL PROGRAMS

Figure 10.1 Summary analytical laboratory's performance evaluation by independent quality control programs for 1995 .

\section{Data Management}

Data management performed for the environmental monitoring program follows the guidelines outlined in the Data and Documents Management Plan (SAIC 1994). This document presents the various components that constitute the overall data management process and establishes roles and responsibilities. The data generated by these programs are stored in the Environmental Information Management System (EIMS), a consolidated site data system for tracking, management, verification, validation, and reporting of environmental data. The EIMS uses a variety of reference and code lists to ensure consistency and to standardize the presentation of data for users.

EIMS performs a computer-based verification and validation of the field and analytical data that are entered from field logbooks and forms or analytical data packages. The verification procedures check for inconsistencies with the reference and codes tables. Examples of these checks include valid sample type, spelling of the analysis name, units, and appropriate methods. Data that pass all of the verification checks are compared with validation criteria, which are established by the data generator during the development of the data quality objectives. Examples of these checks include holding time exceedences, comparison with historical statistics, and comparison with regulatory or permit limits. Validation flags are attached to the data as a result of this step. These validation flags are available to persons using the data to aid in assessing how usable the data are. 


\section{Appendix A: Radiation}

This appendix gives basic facts about radiation. This information is intended as a basis for understanding the dose associated with releases from the Paducah Site, not as a comprehensive discussion of radiation and its effects on the environment and biological systems. The McGraw-Hill dictionary defines radiation and radioactivity as follows:

radiation - 1. The emission and propagation of waves transmitting energy through space or through some medium; for example, the emission and propagation of electromagnetic, sound, or elastic waves. 2. The energy transmitted through space or some medium; when unqualified, usually refers to electromagnetic radiation. Also known as radiant energy. 3. A stream of particles, such as electrons, neutrons, protons, alpha particles, or high-energy photons, or a mixture of these (McGraw-Hill 1989).

radioactivity - $A$ particular type of radiation emitted by a radioactive substance, such as alpha radioactivity (McGraw-Hill 1989).

Radiation occurs naturally; it was not invented, but rather, was discovered. People are constantly exposed to radiation. For example, radon in air; potassium in food and water; and uranium, thorium, and radium in the earth's crust are all sources of radiation. The following discussion describes important aspects of radiation, including atoms and isotopes; types, sources, and pathways of radiation; radiation measurement; and dose information.

\section{ATOMS AND ISOTOPES}

All matter is made up of atoms. An atom is "a unit of matter consisting of a single nucleus surrounded by a number of electrons equal to the number of protons in the nucleus" (ANS 1986). The number of protons in the nucleus determines an element's atomic number, or chemical identity. With the exception of hydrogen, the nucleus of each type of atom also contains at least one neutron. Unlike protons, the number of neutrons may vary among atoms of the same element. The number of neutrons and protons determines the atomic weight. Atoms of the same element with a different number of neutrons are called isotopes. In other words, isotopes have the same chemical properties but different atomic weights. Figure A. I depicts isotopes of the element hydrogen. Another example is the element uranium, which has 92 protons; all isotopes of uranium, therefore, have 92 protons. However, each uranium isotope has a different number of neutrons. Uranium-234 has 92 protons and 142 neutrons; $235 \mathrm{U}$ has 92 protons and 143 neutrons; 238U has 92 protons and 146 neutrons.

Some isotopes are stable, or nonradioactive; some are radioactive. Radioactive isotopes are called radioisotopes, or radionuclides. In an attempt to become stable, radionuclides "throw away," or emit, rays or particles. This emission of rays and particles is known as radioactive decay. 


\section{RADIATION}

Radiation, or radiant energy, is energy in the form of waves or particles moving through space. Visible light, heat, radio waves, and alpha particles are examples of radiation. When people feel warmth from the sunlight, they are actually absorbing the radiant energy emitted by the sun.

Electromagnetic radiation is radiation in the form of electromagnetic waves; examples include gamma rays, ultraviolet light, and radio waves. Particulate radiation is radiation in the form of particles; examples include alpha and beta particles. Radiation also is characterized by the way in which it interacts with matter.

\section{lonizing Radiation}

Normally, an atom has an equal number of protons and electrons; however, atoms can lose or gain electrons in a process known as

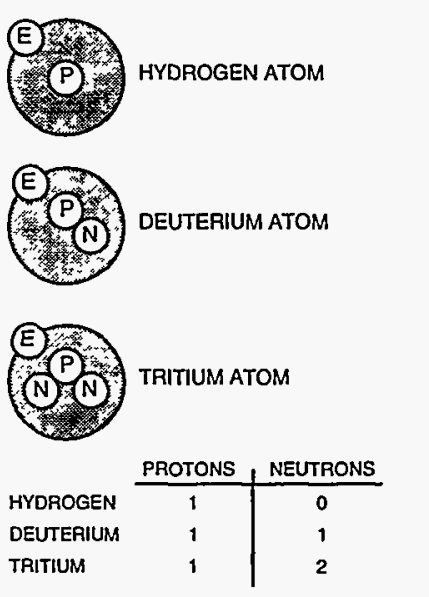

Figure A.1 Isotopes of the element hydrogen ionization. Some forms of radiation can ionize atoms by "knocking" electrons off atoms. Examples of ionizing radiation include alpha, beta, and gamma radiation. Ionizing radiation is capable of changing the chemical state of matter and subsequently causing biological damage and thus is potentially harmful to human health. Figure A.2 shows the penetrating potential of different types of ionizing radiation.

\section{Nonionizing Radiation}

Nonionizing radiation bounces off of or passes through matter without displacing electrons. Examples include visible light and radio waves. Currently, it is unclear whether nonionizing radiation is harmful to human health. In the discussion that follows, the term radiation is used to describe ionizing radiation.

\section{SOURCES OF RADIATION}

Radiation is everywhere. Most occurs naturally, but a small percentage is from human-made sources. Naturally occurring radiation is known as background radiation.

\section{Background Radiation}

Many materials are naturally radioactive. In fact, this naturally occurring radiation is the major source of radiation in the environment. Though people have little control over the amount of background radiation to which they are exposed, this exposure must be put into perspective. Background radiation remains relatively constant over time; background radiation present in the environment today is much the same as it was hundreds of years ago.

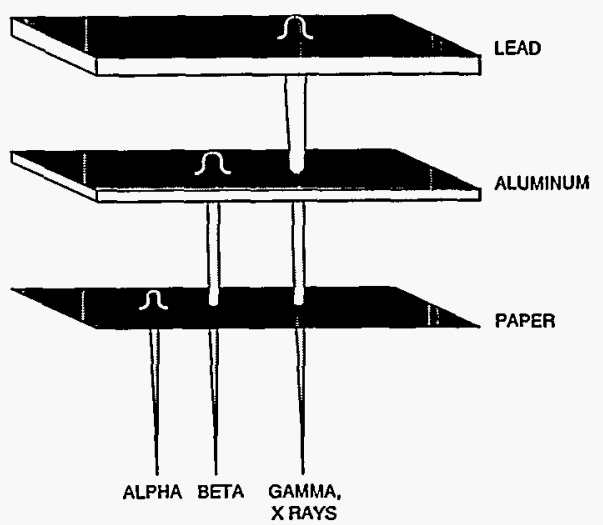

Fig. A.2. Penetrating power of radiation. Some types of radiation can be easily shielded against. For example, a sheet of paper is sufficient to stop an alpha particle. Gamma rays can pass through paper but can be stopped by the appropriate amount of lead. Radiation's ability to penetrate is an important consideration in protecting human health. Adequate shielding decreases the power of radiation by absorbing part or all of it. 
Sources of background radiation include uranium in the earth, radon in the air, and potassium in food. Background radiation is categorized as cosmic, terrestrial, or internal, depending on its origin.

\section{Cosmic Radiation}

Energetically charged particles from outer space continuously hit the earth's atmosphere. These particles and the secondary particles and photons they create are called cosmic radiation. Because the atmosphere provides some shielding against cosmic radiation, the intensity of this radiation increases with altitude above sea level. In other words, a person in Denver, Colorado, is exposed to more cosmic radiation than a person near Paducah, Kentucky.

\section{Terrestrial Radiation}

Terrestrial radiation refers to radiation emitted from radioactive materials in the earth's rocks, soils, and minerals. Radon (Rn); radon progeny, the relatively short-lived decay products of radium-235 $\left.{ }^{235} \mathrm{Ra}\right)$; potassium $\left({ }^{40} \mathrm{~K}\right)$; isotopes of thorium (Th); and isotopes of uranium (U) are the elements responsible for most terrestrial radiation.

\section{Internal Radiation}

Radioactive material in the environment enters the body through the air people breathe and the food they eat; it also can enter through an open wound. Natural radionuclides in the body include isotopes of uranium, thorium, radium, radon, polonium, bismuth, and lead in the ${ }^{238} \mathrm{U}$ and ${ }^{212} \mathrm{Th}$ decay series. In addition, the body contains isotopes of potassium $\left({ }^{40} \mathrm{~K}\right)$, rubidium $\left({ }^{87} \mathrm{Rb}\right)$, and carbon $\left({ }^{14} \mathrm{C}\right)$.

\section{Human-Made Radiation}

In addition to background radiation, there are human-made sources of radiation to which most people are exposed. Examples include consumer products, medical sources, and fallout from atmospheric atomic weapon tests. (Atmospheric testing of atomic weapons has been suspended.) Also, about one-half of $1 \%$ of the U.S. population performs work in which radiation in some form is present.

\section{Consumer Products}

Some consumer products are sources of radiation. In some of these products, such as smoke detectors and airport X-ray baggage inspection systems, the radiation is essential to the performance of the device. In other products, such as televisions and tobacco products, the radiation occurs incidentally to the product function.

\section{Medical Sources}

Radiation is an important tool of diagnostic medicine and treatment and, in this use, is the main source of exposure to human-made radiation. Exposure is deliberate and directly beneficial to the patients exposed. Generally, diagnostic or therapeutic medical exposures result from $X$ ray beams directed to specific areas of the body. Thus, all body organs generally are not irradiated uniformly. Radiation and radioactive materials are also used in a wide variety of pharmaceuticals and in the preparation of medical instruments, 
including the sterilization of heat-sensitive products such as plastic heart valves. Nuclear medicine examinations and treatment involve the internal administration of radioactive compounds, or radiopharmaceuticals, by injection, inhalation, consumption, or insertion. Even then, radionuclides are not distributed uniformly throughout the body.

\section{Other Sources}

Other sources of radiation include fallout from atmospheric atomic weapons tests; emissions of radioactive materials from nuclear facilities such as uranium mines, fuel processing plants, and nuclear power plants; emissions from mineral extraction facilities; and transportation of radioactive materials.

\section{PATHWAYS OF RADIATION}

Radiation and radioactive material in the environment can reach people through many routes. Potential routes for radiation are referred to as pathways. For example, radioactive material in the air could fall on a pasture. The grass could then be eaten by cows, and the radioactive material on the grass would show up in the cow's milk. People drinking the milk would thus be exposed to this radiation. Or, people could simply inhale the radioactive material in the air. The same events could occur with radioactive material in water. Fish living in the water would be exposed; people eating the fish would then be exposed to the radiation in the fish. Or, people swimming in the water would be exposed, see Figure A.3.

\section{MEASURING RADIATION}

To determine the possible effects of radiation on the environment and the health of people, the radiation must be measured. More precisely, its potential to cause damage must be determined.

\section{Activity}

When measuring the amount of radiation in the environment, what is actually being measured is the rate of radioactive decay, or activity. The rate of decay varies widely among the various radioisotopes. For that reason, $1 \mathrm{~g}$ of a radioactive substance may contain the same amount of activity as several tons of another material. This activity is expressed in a unit of measure known as a curie (Ci). More specifically, $1 \mathrm{Ci}=$ $3.7 \mathrm{E}+10(37,000,000,000)$ atom disintegrations per second

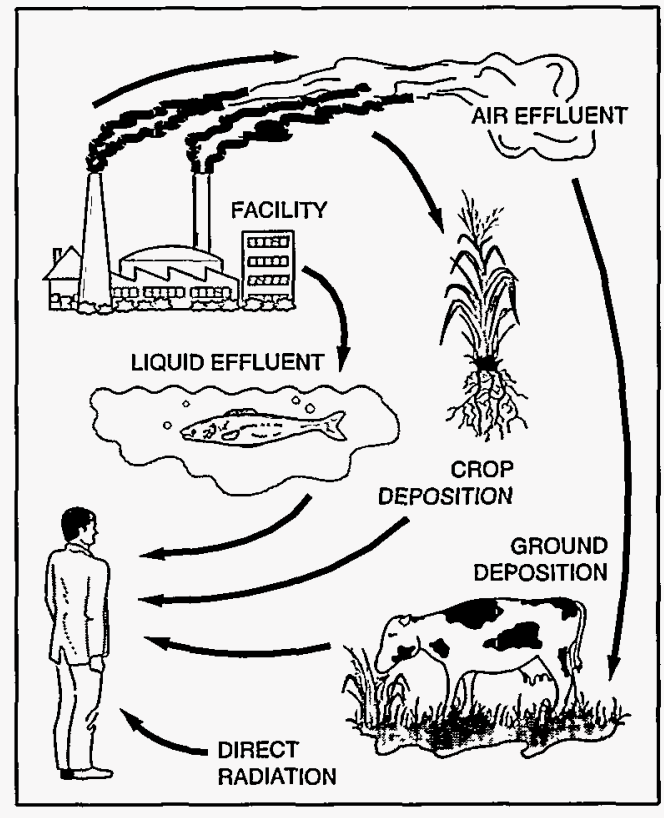

Figure A.3 Possible radiation pathways (dps). In the international system of units, $1 \mathrm{dps}=1$ becquerel $(\mathrm{Bq})$.

\section{Absorbed Dose}

The total amount of energy absorbed per unit mass as a result of exposure to radiation is expressed in a unit of measure known as a rad. In the international system of units, $100 \mathrm{rad}=1$ gray (Gy). However, in 
terms of human health, it is the effect of the absorbed energy that is important because some forms of radiation are more harmful than others as a result of their energy deposition pattern.

\section{Dose Equivalent}

The measure of potential biological damage caused by exposure to and subsequent absorption of radiation is expressed in a unit of measure known as a rem. One rem of any type of radiation has the same total damaging effect. Because a rem represents a fairly large dose, dose is expressed as a millirem (mrem), or $1 / 1000$ of a rem. In the international system of units, $100 \mathrm{rem}=1$ Sievert (Sv); $100 \mathrm{mrem}=1$ millisievert (mSv).

\section{DOSE}

Many terms are used to report dose. Several factors are taken into account, including the amount of radiation absorbed, the organ absorbing the radiation, and the effect of the radiation over a 50-year period. The term "dose," in this report, includes the committed effective dose equivalent (EDE) and the EDE attributable to penetrating radiation from sources external to the body.

Determining dose is an involved process using complex mathematical equations based on several factors, including the type of radiation, the rate of exposure, weather conditions, and typical diet. Basically, radiant energy is generated from radioactive decay, or activity. People absorb some of the energy to which they are exposed. This absorbed energy is calculated as part of an individual's dose. Whether radiation is natural or human made, its effects on people are the same.

\section{Comparison of Dose Levels}

A scale of dose levels is presented in Table A. 1. Included is an example of the type of exposure that may cause such a dose or the special significance of such a dose. This information is intended to help the reader become familiar with the type of doses individuals may receive.

\section{Dose from Cosmic Radiation}

The average annual dose received by residents of the United States from cosmic radiation is about 27 mrem $(0.27 \mathrm{mSv})$ (NCRP 1987). The average annual dose from cosmic radiation received by residents in the Paducah area is about $45 \mathrm{mrem}(0.45 \mathrm{mSv})$. 
Table A.1 Comparison and description of various dose levels

\begin{tabular}{|c|c|}
\hline Dose level & Description \\
\hline $1 \mathrm{mrem}(0.01 \mathrm{mSv})$ & Approximate daily dose from natural background radiation, including radon \\
\hline $2.5 \mathrm{mrem}(0.025 \mathrm{mSv})$ & Cosmic dose to a person on a one-way airplane flight from New York to Los Angeles \\
\hline $10 \mathrm{mrem}(0.10 \mathrm{mSv})$ & $\begin{array}{l}\text { Annual exposure limit, set by the EPA for exposures from airborne emissions from operations of } \\
\text { nuclear fuel cycle facilities, including power plants and uranium mines and mills }\end{array}$ \\
\hline $45 \mathrm{mrem}(0.45 \mathrm{mSv})$ & Average yearly dose from cosmic radiation received by people in the Paducah area \\
\hline $46 \mathrm{mrem}(0.46 \mathrm{mSv})$ & $\begin{array}{l}\text { Estimate of the largest dose any off-site person could have received from the March } 28,1979 \text {, } \\
\text { Three Mile Island nuclear power plant accident }\end{array}$ \\
\hline 66 mrem $(0.66 \mathrm{mSv})$ & Average yearly dose to people in the United States from human-made sources \\
\hline 100 mrem $(1.00 \mathrm{mSv})$ & $\begin{array}{l}\text { Annual limit of dose from all U.S. Department of Energy facilities to a member of the public who } \\
\text { is not a radiation worker }\end{array}$ \\
\hline $110 \mathrm{mrem}(1.10 \mathrm{mSv})$ & Average occupational dose received by U.S. commercial radiation workers in 1980 \\
\hline $244 \operatorname{mrem}(2.44 \mathrm{mSv})$ & Average dose from an upper gastrointestinal diagnostic $\mathrm{X}$-ray series \\
\hline 300 mrem $(3.00 \mathrm{mSv})$ & $\begin{array}{l}\text { Average yearly dose to people in the United States from all sources of natural background } \\
\text { radiation }\end{array}$ \\
\hline $1-5$ rem $(0.01-0.05 \mathrm{~Sv})$ & $\begin{array}{l}\text { EPA protective action guidelines state that public officials should take emergency action when } \\
\text { the dose to a member of the public from a nuclear accident will likely reach this range }\end{array}$ \\
\hline $5 \mathrm{rem}(0.05 \mathrm{~Sv})$ & $\begin{array}{l}\text { Annual limit for occupational exposure of radiation workers set by the U.S. Nuclear Regulatory } \\
\text { Commission and the U.S. Department of Energy }\end{array}$ \\
\hline $10 \mathrm{rem}(0.10 \mathrm{~Sv})$ & $\begin{array}{l}\text { The BEIR V report estimated that an acute dose at this level would result in a lifetime excess risk } \\
\text { of death from cancer, caused by the radiation, of } 0.8 \% \text { (BEIR 1990) }\end{array}$ \\
\hline $25 \mathrm{rem}(0.25 \mathrm{~Sv})$ & $\begin{array}{l}\text { EPA guideline for voluntary maximum dose to emergency workers for non-lifesaving work } \\
\text { during an emergency }\end{array}$ \\
\hline $75 \mathrm{rem}(0.75 \mathrm{~Sv})$ & EPA guideline for maximum dose to emergency workers volunteering for lifesaving work \\
\hline $\begin{array}{l}50-600 \text { rem }(0.50-6.00 \\
\text { Sv) }\end{array}$ & $\begin{array}{l}\text { Doses in this range received over a short period of time will produce radiation sickness in } \\
\text { varying degrees. At the lower end of this range, people are expected to recover completely, given } \\
\text { proper medical attention. At the top of this range, most people would die within } 60 \text { days }\end{array}$ \\
\hline
\end{tabular}

Adapted -from Savannah River Site Environmental Report for 1993, Summary Pamphlet, WSRC-TR-94076, Westinghouse Savannah River Company, 1994. 


\section{Dose Terminology}

absorbed dose

quantity of radiation energy absorbed by an organ divided by an organ's mass

dose equivalent

absorbed dose to an organ multiplied by a quality factor

effective dose equivalent

single weighted sum of combined dose equivalents received by all organs

committed dose equivalent

effective dose equivalent to an organ over a 50-year period following intake

committed effective dose equivalent

total effective dose equivalent to all organs in the human body over a 50-year period following intake

collective effective dose equivalent

sum of effective dose equivalents of all members of a given population

quality factor

a modifying factor used to adjust for the effect of the type of radiation, for example, alpha particles or gamma rays, on tissue

weighting factor

tissue-specific modifying factor representing the fraction of the total health risk from uniform, whole-body exposure

\section{Dose from Terrestrial Radiation}

The average annual dose received from terrestrial gamma radiation is about $28 \mathrm{mrem}(0.28 \mathrm{mSv})$ in the United States. This dose varies geographically across the country (NCRP 1987); typical reported values are $16 \mathrm{mrem}(0.16 \mathrm{mSv})$ at the Atlantic and Gulf coastal plains and $63 \mathrm{mrem}(0.63 \mathrm{mSv})$ at the eastern slopes of the Rocky Mountains.

\section{Dose from Internal Radiation}

Short-lived decay products of radon are the major contributors to the annual dose equivalent for internal radionuclides (mostly ${ }^{222} \mathrm{Rn}$ ). They contribute an average dose of about $200 \mathrm{mrem}(2.00 \mathrm{mSv})$ per year. This dose estimate is based on an average radon concentration of about $1 \mathrm{pCi} / \mathrm{L}(0.037 \mathrm{~Bq} / \mathrm{L})$ (NCRP 1987).

The average dose from other internal radionuclides is about $39 \mathrm{mrem}(0.39 \mathrm{mSv})$ per year, most of which can be attributed to the naturally occurring isotope of potassium, ${ }^{40} \mathrm{~K}$. The concentration of radioactive potassium in human tissues is similar in all parts of the world. 


\section{Dose from Consumer Products}

The U.S. average annual dose received by an individual from consumer products is about 10 mrem $(0.10$ $\mathrm{mSv}$ ) (NCRP 1987).

\section{Dose from Medical Sources}

Nuclear medicine examinations, which involve the internal administration of radiopharmaceuticals, generally account for the largest portion of the dose received from human-made sources. However, the radionuclides used in specific tests are not distributed uniformly throughout the body. In these cases, comparisons are made using the concept of EDE, which relates exposure of organs or body parts to one effective whole-body dose. The average annual EDE from medical examinations is $53 \mathrm{mrem}(0.53 \mathrm{mSv})$, including $39 \mathrm{mrem}(0.39 \mathrm{mSv})$ for diagnostic $X$ rays and $14 \mathrm{mrem}(0.14 \mathrm{mSv})$ for nuclear medicine procedures (NCRP 1989). The actual doses received by individuals who complete such medical exams are much higher than these values, but not everyone receives such exams each year (NCRP 1989).

\section{Dose from Other Sources}

Small doses received by individuals occur as a result of radioactive fallout from atmospheric atomic weapons tests, emissions of radioactive materials from nuclear facilities, emissions from certain mineral extraction facilities, and transportation of radioactive materials. The combination of these sources contributes less than $1 \mathrm{mrem}(0.01 \mathrm{mSv})$ per year to the average dose to an individual (NCRP 1987).

A comprehensive EPA report of 1984 projected the average occupational dose to monitored radiation workers in medicine, industry, the nuclear fuel cycle, government, and miscellaneous industries to be 105 mrem (1.05 mSv) per year for 1985 , down slightly from $110 \mathrm{mrem}(1.10 \mathrm{mSv})$ per year in 1980 (Kumazawa et al. 1984). 


\section{Appendix B: Radionuclide and Chemical Nomenclature}

Nomenclature and half-life for radionuclides

\begin{tabular}{|l|l|l|l|l|l|}
\hline Radionuclide & Symbol & Half-life & Radionuclide & Symbol & Half-life \\
\hline Bismuth-210 & ${ }^{210} \mathrm{Bi}$ & 5.01 days & Radium-226 & ${ }^{226} \mathrm{Ra}$ & 1,602 years \\
\hline Bismuth-214 & ${ }^{214} \mathrm{Bi}$ & 19.7 minutes & Radon-222 & ${ }^{222} \mathrm{Ra}$ & 3.821 days \\
\hline Lead-206 & ${ }^{206} \mathrm{~Pb}$ & Stable & Technetium-99 & ${ }^{99} \mathrm{Tc}$ & 212,000 years \\
\hline Lead-210 & ${ }^{210} \mathrm{~Pb}$ & 21 years & Thorium-230 & ${ }^{230} \mathrm{Th}$ & 80,000 years \\
\hline Lead-214 & ${ }^{210} \mathrm{~Pb}$ & 26.8 minutes & Thorium-231 & ${ }^{231} \mathrm{Th}$ & 25.5 hours \\
\hline Polonium-210 & ${ }^{210} \mathrm{Po}$ & 138.9 days & Thorium-234 & ${ }^{234} \mathrm{Th}$ & 24.1 days \\
\hline Polonium-214 & ${ }^{214} \mathrm{Po}$ & 164 microseconds & Uranium-234 & ${ }^{234} \mathrm{U}$ & 247,000 years \\
\hline Polonium-218 & ${ }^{218} \mathrm{Po}$ & 3.05 minutes & Uranium-235 & ${ }^{235} \mathrm{U}$ & $710,000,000$ years \\
\hline Potassium-40 & ${ }^{40} \mathrm{~K}$ & $1,260,000,000$ years & Uranium-236 & ${ }^{236} \mathrm{U}$. & $23,900,000$ years \\
\hline $\begin{array}{l}\text { Protactinium- } \\
234 \mathrm{~m}\end{array}$ & ${ }^{234 \mathrm{~m}} \mathrm{~Pa}$ & 1.17 minutes & Uranium-238 & ${ }^{238} \mathrm{U}$ & $4,510,000,000$ years \\
\hline
\end{tabular}




\section{Nomenclature for elements and chemical constituents}

\begin{tabular}{|c|c|c|c|}
\hline Constituent & Symbol & Constituent & Symbol \\
\hline Aluminum & $\mathrm{Al}$ & Manganese & $\mathrm{Mn}$ \\
\hline Ammonia & NH3 & Mercury & $\mathrm{Hg}$ \\
\hline Antimony & $\mathrm{Sb}$ & Nickel & $\mathrm{Ni}$ \\
\hline Arsenic & As & Nitrogen & $\mathrm{N}$ \\
\hline Barium & $\mathrm{Ba}$ & Nitrate & $\mathrm{NO}_{3}$ \\
\hline Beryllium & $\mathrm{Be}$ & Nitrite & $\mathrm{NO}_{2}$ \\
\hline Cadmium & $\mathrm{Cd}$ & Oxygen & 0 \\
\hline Calcium & $\mathrm{Ca}$ & Ozone & $\mathrm{O}_{3}$ \\
\hline Calcium carbonate & $\mathrm{CaCO}_{3}$ & Phosphorus & $\mathrm{P}$ \\
\hline Carbon & $\mathrm{C}$ & Phosphate & $\mathrm{PO}_{4}$ \\
\hline Chlorine & $\mathrm{Cl}$ & Potassium & $\mathrm{K}$ \\
\hline Chromium & $\mathrm{Cr}$ & Radium & $\mathrm{Ra}$ \\
\hline Chromium, hexavalent & $\mathrm{Cr}^{6+}$ & Radon & Rn \\
\hline Cobalt & Co & Selenium & $\mathrm{Se}$ \\
\hline Copper & $\mathrm{Cu}$ & Silver & $\mathrm{Ag}$ \\
\hline Fluorine & $\mathrm{F}$ & Sodium & $\mathrm{Na}$ \\
\hline Hydrogen fluoride & $\mathrm{HF}$ & Sulfate & $\mathrm{SO}_{4}$ \\
\hline Iron & $\mathrm{Fe}$ & Sulfur dioxide & $\mathrm{SO}_{2}$ \\
\hline Lead & $\mathrm{Pb}$ & Thorium & Th \\
\hline Lithium & $\mathrm{Li}$ & Uranium & $U$ \\
\hline Magnesium & $\mathrm{Mg}$ & Zinc & $\mathrm{Zn}$ \\
\hline
\end{tabular}




\section{References}

American Nuclear Society (ANS). 1986. Glossary of Terms in Nuclear Science and Technology, American Nuclear Society.

BEIR. 1990. Health Effects of Exposure to Low Levels o Ionizing Radiation, Committee on the Biological Effects of Ionizing Radiation (BEIR V), National Research Council, National Academy of Sciences, National Academy Press, Washington, D.C.

Blewett, Jennifer R., 1996. LMES PGDP Groundwater Program Quality Assurance Plan, Lockheed Martin Energy Systems, Inc., Paducah Gaseous Diffusion Plant

CDM. 1992. Site Investigation of the Underground Storage Tanks at the C-200, C-710, and C-750 Buildings, Paducah Gaseous Diffusion Plant, Paducah, Kentucky, Volume 1. CDM Federal Programs Corporation, Oak Ridge, Tennessee.

CH2M Hill. 1990. Draft Results of the Site Investigation Phase I at the Paducah Gaseous Diffusion Plant, Paducah, Ky., KY/ER-4, Paducah Gaseous Diffusion Plant, Paducah, Ky.

CH2M Hill. 1991a. Results of the Public Health and Ecological Assessment, Phase II at the Paducah Gaseous Diffusion Plant (Draft), KY/SUB/13B-97777C P-03/1991/1.

CH2M Hill. 1991b. Results of the Site Investigation, Phase I, at the Paducah Gaseous Diffusion Plant, Paducah, Ky., KY/ER-4, Paducah Gaseous Diffusion Plant, Paducah, Ky.

CH2M Hill. 1992b. Results of the Public Health and Ecological Assessment, Phase II, at the Paducah Gaseous Diffusion Plant, Paducah, Kentucky, KY/SUB/13B-97777C P-03/1991/1, Paducah Gaseous Diffusion Plant, Paducah, Ky.

Clausen, J. L. 1995. Paducah Gaseous Diffusion Plant Groundwater Protection Program Plan Addendum to Sampling and Analysis Plan, KY/ER-2/Addendum 1, Rev. 1, Martin Marietta Energy Systems, Inc., Paducah Gaseous Diffusion Plant.

Early, T. O., C. F. Sigmon, and R. T. Williams. 1989. Groundwater Monitoring Plan for the Paducah Gaseous Diffusion Plant, Paducah, Kentucky, Battelle Columbus Laboratories, Columbus, Ohio.

International Commission on Radiological Protection (ICRP). 1979. Annals of ICRP Publication 30, Parts I and II, Limits of Intakes of Radionuclides by Workers, ICRP Publication 30, Pergamon, Oxford, N.Y.

Jett, T. June 1992. Quality Assurance Plan for the Environmental Monitoring Department, QAP12-920005, Martin Marietta Energy Systems, Inc., Paducah Gaseous Diffusion Plant.

Jinks, S. M., and M. Eisenbud. 1972. "Concentration Factors in Aquatic Environment," Radia. Data Rep. $13,243$. 
Klement, Alfred W., Jr., et al. August 1972. Estimates of Ionizing Radiation Doses in the United States 1960-2000, Office of Radiation Programs, Rockville, Md.

Kszos, L. A. (ed). 1996. Report on the Biological Monitoring Program at Paducah Gaseous Diffusion Plant January-December 1995. ORNL/TM-13190. Oak Ridge, Tennessee.

Kumazawa S., et al. 1984. Occupational Exposure to Ionizing Radiation in the United States: A Comprehensie Review for the Year 1980 and a Summary of Trends for the Years 1960-1985, EPA/520/18-005, U.S> Government Printing Office, Washington, D.C.

Lockheed Martin Energy Systems, Inc. (LMES). 1995. Environmental Monitoring Plan, KY/EM-117, Lockheed Martin Energy Systems, Inc., Paducah Site.

Lockheed Martin Energy Systems, Inc. (LMES). 1995a. Paducah Site Annual Environmental Report for 1994, ES/ESH-60, KY/EM-79, Lockheed Martin Energy Systems, Inc., Paducah Site.

Martin Marietta Energy Systems, Inc. (MMES). 1994b. Interim Corrective Measures Work Plan for the Northeast Plume Paducah Gaseous Diffusion Plant, Paducah, Kentucky, DOE/OR-1205\&D2, Department of Energy, Paducah, Kentucky.

McGraw-Hill. 1989. McGraw-Hill Dictionary of Scientific and Technical Terms, 4th ed. McGraw-Hill, Inc.

Miller, G. R. and J. W. Douthitt. 1993. Paducah Gaseous Diffusion Plant Groundwater Protection Program Management Plan, KY/ER-30, Martin Marietta Energy Systems, Inc., Paducah Gaseous Diffusion Plant.

National Council on Radiation Protection and Measurements (NCRP). 1987. "Ionizing Radiation Exposure of the Population of the United States," NCRP Report No. 93, Washington, D.C.

National Council on Radiation Protection and Measurements (NCRP). 1989. "Exposure of the U.S. Population from Diagnostic Medical Radiation," NCRP Report No. 100, Bethesda Md.

Science Applications International Corporation (SAIC). 199la. Summary of Alternatives for Remediation of Off-Site Contamination at the Paducah Gaseous Diffusion Plant, Paducah, Kentucky (Draft).

Science Applications International Corporation (SAIC). 1992. Draft Environmental Assessment: Construction and Operation of Residential Landfill Cell No. 3 at the Paducah Gaseous Diffusion Plant, Paducah, Kentucky (Rev. 2), Oak Ridge, Tenn.

Science Applications International Corporation (SAIC). 1993b. Groundwater Surveillance for the Paducah Gaseous Diffusion Plant, KY/ER-38, Martin Marietta Energy Systems, Inc. Paducah Gaseous Diffusion Plant. 
Science Applications International Corporation (SAIC). March 1994. Data and Documents Management Plan for the Environmental Restoration Program Assessment Activities, DOE/OR/07-1150\&D1, Paducah Gaseous Diffusion Plant, Paducah, Ky.

U.S. Department of Energy (DOE). July 1988. Internal Dose Conversion Factors for Calculations of Dose to the Public, DOE/EH-00071, U.S. Department of Energy. 


\section{Glossary}

absorption - The process by which the number and energy of particles or photons entering a body of matter is reduced by interaction with the matter.

activity - See radioactivity.

alpha particle - A positively charged particle emitted from the nucleus of an atom having the same charge and mass as that of a helium nucleus (two protons and two neutrons).

ambient air - The atmosphere around people, plants, and structures.

analytical detection limit - The lowest reasonably accurate concentration of an analyte that can be detected; this value varies depending on the method, instrument, and dilution used.

analyte - A constituent or parameter being analyzed.

aquifer - A saturated, permeable geologic unit that can transmit significant quantities of water under ordinary hydraulic gradients.

aquitard - A geologic unit that inhibits the flow of water.

assimilate - To take up or absorb.

atom - Smallest particle of an element capable of entering into a chemical reaction.

beta particle - A negatively charged particle emitted from the nucleus of an atom. It has a mass and charge equal to those of an electron.

biota - The animal and plant life of a particular region considered as a total ecological entity.

CERCLA-reportable release - A release to the environment that exceeds reportable quantities as defined by CERCLA (Comprehensive Environmental Response, Compensation, and Liability Act).

chain of custody - A form that documents sample collection, transport, analysis, and disposal.

Ci-See curie.

closure - Formal shutdown of a hazardous waste management facility under Resource Conservation and Recovery Act requirements.

compliance - Fulfillment of applicable requirements of a plan or schedule ordered or approved by government authority. 
concentration - The amount of a substance contained in a unit volume or mass of a sample.

conductivity - A measure of water's capacity to convey an electric current. This property is related to the total concentration of the ionized substances in water and the temperature at which the measurement is made.

confluence - The point at which two or more streams meet; the point where a tributary joins the main stream.

contamination - Deposition of unwanted material on the surfaces of structures, areas, objects, or personnel.

cosmic radiation - Ionizing radiation with very high energies that originates outside the earth's atmosphere. Cosmic radiation is one contributor to natural background radiation.

curie (Ci) - A unit of radioactivity. One curie is defined as $3.7 \times 10^{10}$ (37 billion) disintegrations per second. Several fractions and multiples of the curie are commonly used:

kilocurie (kCi) $-10^{3} \mathrm{Ci}$, one thousand curies; $3.7 \times 10^{13}$ disintegrations per second. millicurie ( $\mathrm{mCi}$ ) $-10^{-3} \mathrm{Ci}$, one-thousandth of a curie; $3.7 \times 10^{7}$ disintegrations per second. microcurie $(\mathrm{gCi})-10^{6} \mathrm{Ci}$, one-millionth of a curie; $3.7 \times 10^{4}$ disintegrations per second. picocurie (pCi) $-10^{12} \mathrm{Ci}$, one-trillionth of a curie; 0.037 disintegrations per second.

daughter - A nuclide formed by the radioactive decay of a parent nuclide.

DCG - See derived concentration guide.

decay, radioactive - The spontaneous transformation of one radionuclide into a different radioactive or nonradioactive nuclide or into a different energy state of the same radionuclide.

decontamination and decommissioning - See Environmental Restoration.

dense nonaqueous phase liquid (DNAPL) - The liquid phase of chlorinated organic solvents. These liquids are denser than water and include commonly used industrial compounds such as tetrachloroethylene and trichloroethylene.

derived concentration guide (DCG) - The concentration of a radionuclide in air or water that under conditions of continuous exposure for one year by one exposure mode (i.e., ingestion of water, submersion in air, or inhalation) would result in either an effective dose equivalent of $0.1 \mathrm{rem}(1 \mathrm{mSv})$ or a dose equivalent of $5 \mathrm{rem}(50 \mathrm{mSv})$ to any tissue, including skin and the lens of the eye. The guidelines for radionuclides in air and water are given in DOE Order 5400.5, Radiation Protection of the Public and the Environment.

disintegration, nuclear - A spontaneous nuclear transformation (radioactivity) characterized by the emission of energy and/or mass from the nucleus of an atom. 
DNAPL - See dense nonaqueous phase liquid.

dose - The energy imparted to matter by ionizing radiation. The unit of absorbed dose is the rad, equal to 0.01 joules per kilogram in any medium.

absorbed dose - The quantity of radiation energy absorbed by an organ divided by the organ's mass. Absorbed dose is expressed in units of $\mathrm{rad}$ (or gray) ( $\mathrm{I} \mathrm{rad}=0.01 \mathrm{~Gy}$ ).

dose equivalent - The product of the absorbed dose (rad) in tissue and a quality factor. Dose equivalent is expressed in units of rem (or sievert) (I rem $=0.01 \mathrm{~Sv}$ ).

committed dose equivalent - The calculated total dose equivalent to a tissue or organ over a 50year period after known intake of a radionuclide into the body. Contributions from external dose are not included. Committed dose equivalent is expressed in units of rem (or sievert).

committed effective dose equivalent - The sum of the committed dose equivalents to various tissues in the body, each multiplied by the appropriate weighting factor. Committed effective dose equivalent is expressed in units of rem (or sievert).

effective dose equivalent - The sum of the dose equivalents received by all organs or tissues of the body after each one has been multiplied by an appropriate weighting factor. The effective dose equivalent includes the committed effective dose equivalent from internal deposition of radionuclides and the effective dose equivalent attributable to sources external to the body. collective dose equivalent/collective effective dose equivalent - The sums of the dose equivalents or effective dose equivalents of all individuals in an exposed population within a $50-$ mile $(80-\mathrm{km})$ radius expressed in units of person-rem (or person-sievert). When the collective dose equivalent of interest is for a specific organ, the units would be organ-rem (or organ-sievert). The 50-mile distance is measured from a point located centrally with respect to major facilities or DOE program activities.

dosimeter - A portable detection device for measuring the total accumulated exposure to ionizing radiation.

dosimetry - The theory and application of principles and techniques involved in the measurement and recording of radiation doses. Its practical aspect is concerned with using various types of radiation instruments to make measurements.

downgradient - In the direction of decreasing hydrostatic head.

downgradient well - $\mathrm{A}$ well that is installed hydraulically downgradient of a site and that may be capable of detecting migration of contaminants from a site.

drinking water standards (DWS) - Federal primary drinking water standards, both proposed and final, as set forth by the U.S. Environmental Protection Agency.

DWS - See drinking water standards.

effluent - A liquid or gaseous waste discharge to the environment. 
effluent monitoring - The collection and analysis of samples or measurements of liquid and gaseous effluents for purposes of characterizing and quantifying the release of contaminants, assessing radiation exposures of members of the public, and demonstrating compliance with applicable standards.

Environmental Restoration - A DOE program that directs the assessment and cleanup of its sites (remediation) and facilities (decontamination and decommissioning) contaminated with waste as a result of nuclear-related activities.

exposure (radiation) - The incidence of radiation on living or inanimate material by accident or intent. Background exposure is the exposure to natural background ionizing radiation. Occupational exposure is that exposure to ionizing radiation that takes place at a person's workplace. Population exposure is the exposure to the total number of persons who inhabit an area.

external radiation - Exposure to ionizing radiation when the radiation source is located outside the body.

fauna - The population of animals at a given area, environment, formation, or time span.

flora - The population of plants at a given area, environment, formation, or time span.

formation - A mappable unit of consolidated or unconsolidated geologic material of a characteristic lithology or assemblage of lithologies.

gamma ray - High-energy, short-wavelength electromagnetic radiation emitted from the nucleus of an excited atom. Gamma rays are identical to $\mathrm{X}$ rays except for the source of the emission.

gamma spectrometry - A system consisting of a detector, associated electronics, and a multichannel analyzer that is used to analyze samples for gamma-emitting radionuclides.

Gaussian puff/plume model - A computer-simulated atmospheric dispersion of a release using a Gaussian (normal) statistical distribution to determine concentrations in air.

Geiger-Mueller (GM) counter - A highly sensitive, gas-filled radiation detector that operates at voltages sufficiently high to produce ionization. The counter is used primarily in the detection of gamma radiation and beta emission. It is named for Hans Geiger and W. Mueller, who invented it in 1928.

grab sample - A sample collected instantaneously with a glass or plastic bottle placed below the water surface to collect surface water samples (also called dip samples).

groundwater, unconfined - Groundwater exposed to the unsaturated zone.

half-life, radiological - The time required for half of a given number of atoms of a specific radionuclide to decay. Each nuclide has a unique half-life.

hydrology - The science dealing with the properties, distribution, and circulation of natural water systems.

hydrogeology - Hydraulic aspects of site geology. 
in situ - In its original place; field measurements taken without removing the sample from its origin; remediation performed while groundwater remains below the surface.

internal dose factor - A factor used to convert intakes of radionuclides to dose equivalents.

internal radiation - Occurs when natural radionuclides enter the body by ingestion of foods, milk, or water or by inhalation. Radon is the major contributor to the annual dose equivalent for internal radionuclides.

ion - An atom or compound that carries an electrical charge.

irradiation - Exposure to radiation.

isotopes - Forms of an element having the same number of protons but differing numbers of neutrons in their nuclei.

long-lived isotope - A radionuclide that decays at such a slow rate that a quantity of it will exist for an extended period (half-life is greater than three years).

short-lived isotope - A radionuclide that decays so rapidly that a given quantity is transformed almost completely into decay products within a short period (half-life is two days or less).

LLD - See lower limit of detection.

lower limit of detection (LLD) - The smallest concentration or amount of analyte that can be reliably detected in a sample at a $95 \%$ confidence level.

maximally exposed individual - A hypothetical individual who remains in an uncontrolled area and would, when all potential routes of exposure from a facility's operations are considered, receive the greatest possible dose equivalent.

migration - The transfer or movement of a material through air, soil, or groundwater.

milliroentgen $(\mathbf{m R})$ - A measure of X-ray or gamma radiation. The unit is one-thousandth of a roentgen.

minimum detectable concentration - The smallest amount or concentration of a radionuclide that can be distinguished in a sample by a given measurement system at a preselected counting time and at a given confidence level.

monitoring - Process whereby the quantity and quality of factors that can affect the environment or human health are measured periodically to regulate and control potential impacts.

mrem - The dose equivalent that is one-thousandth of a rem.

natural radiation - Radiation from cosmic and other naturally occurring radionuclide (such as radon) sources in the environment. 
nuclide - An atom specified by its atomic weight, atomic number, and energy state. A radionuclide is a radioactive nuclide.

outcrop - A place where groundwater is discharged to the surface. Springs, swamps, and beds of streams and rivers are the outcrops of the water table.

outfall - The point of conveyance (e.g., drain or pipe) of wastewater or other effluents into a ditch, pond, or river.

part per billion (ppb) - A unit measure of concentration equivalent to the weight/volume ratio expressed as $\mu \mathrm{g} / \mathrm{L}$ or $\mathrm{ng} / \mathrm{mL}$.

part per million (ppm) - A unit measure of concentration equivalent to the weight/volume ratio expressed as $\mathrm{mg} / \mathrm{L}$.

person-rem - Collective dose to a population group. For example, a dose of 1 rem to 10 individuals results in a collective dose of 10 person-rem.

pH - A measure of the hydrogen ion concentration in an aqueous solution. Acidic solutions have a pH from 0 to 6 , neutral solutions have a $\mathrm{pH}$ equal to 7 , and basic solutions have a $\mathrm{pH}$ greater than 7 .

piezometer - An instrument used to measure the potentiometric surface of the groundwater; also, a well designed for this purpose.

ppb - See part per billion.

ppm - See part per million.

process water - Water used within a system process.

process sewer - Pipe or drain, generally located underground, used to carry off process water or waste matter.

purge - To remove water before sampling, generally by pumping or bailing.

QA - See quality assurance.

QC - See quality control.

quality assurance (QA) - Any action in environmental monitoring to ensure the reliability of monitoring and measurement data.

quality control (QC) - The routine application of procedures within environmental monitoring to obtain the required standards of performance in monitoring and measurement processes. 
quality factor - The factor by which the absorbed dose (rad) is multiplied to obtain a quantity that expresses, on a common scale for all ionizing radiation, the biological damage to exposed persons. A quality factor is used because some types of radiation, such as alpha particles, are more biologically damaging than others.

rad - The unit of absorbed dose deposited in a volume of material.

radiation detection instruments - Devices that detect and record the characteristics of ionizing radiation.

radioactivity - The spontaneous emission of radiation, generally alpha or beta particles or gamma rays, from the nucleus of an unstable isotope.

radioisotopes - Radioactive isotopes.

radionuclide - An unstable nuclide capable of spontaneous transformation into other nuclides by changing its nuclear configuration or energy level. This transformation is accompanied by the emission of photons or particles.

RCRA - See Resource Conservation and Recovery Act.

reference material - A material or substance with one or more properties that is sufficiently well established and used to calibrate an apparatus, to assess a measurement method, or to assign values to materials.

release - Any discharge to the environment. Environment is broadly defined as any water, land, or ambient air.

rem - The unit of dose equivalent (absorbed dose in rads ' the radiation quality factor). Dose equivalent is frequently reported in units of millirem (mrem), which is one-thousandth of a rem.

remediation - The correction of a problem. See Environmental Restoration.

Resource Conservation and Recovery Act (RCRA) - Federal legislation that regulates the transport, treatment, and disposal of solid and hazardous wastes.

RFI Program - RCRA Facility Investigation Program; EPA-regulated investigation of a solid waste management unit with regard to its potential impact on the environment.

roentgen - A unit of exposure from $\mathrm{X}$ rays or gamma rays. One roentgen equals $2.58 \mathrm{X} 104$ coulombs per kilogram of air.

routine radioactive release - A planned or scheduled release of radioactivity to the environment.

screen zone - In well construction, the section of a formation that contains the screen, or perforated pipe, that allows water to enter the well. 
sidegradient well - A well that intercepts groundwater flowing next to a site; a sidegradient well is located neither upgradient nor downgradient to the monitored site.

sievert (Sv) - The SI (International System of Units) unit of dose equivalent; I Sv 100 rem.

slurry - A suspension of solid particles (sludge) in water.

solid waste disposal facility (SWDF) - A place for burying unwanted radioactive material to prevent escape of radioactivity. The surrounding water acts as a shield. Such material is placed in watertight, noncorrodible containers so that it cannot leach out and invade underground water.

source - A point or object from which radiation or contamination emanates.

specific conductance - The ability of water to conduct electricity; this ability varies in proportion to the amount of ionized minerals in the water.

stable - Not radioactive or not easily decomposed or otherwise modified chemically.

storm water runoff - Surface streams that appear after precipitation.

strata - Beds, layers, or zones of rocks.

substrate - The substance, base, surface, or medium in which an organism lives and grows.

surface water - All water on the surface of the earth, as distinguished from groundwater.

suspended solids - Mixture of fine, nonsettling particles of any solid within a liquid or gas.

Sv - See sievert.

SWDF - See solid waste disposal facility.

terrestrial radiation - Ionizing radiation emitted from radioactive materials, primarily ${ }^{40} \mathrm{~K}$, thorium, and uranium, in the earth's soils. Terrestrial radiation contributes to natural background radiation.

thermoluminescent dosimeter (TLD) - A device used to measure external gamma radiation.

TLD - See thermoluminescent dosimeter.

total activity - The total quantity of radioactive decay particles that are emitted from a sample.

total solids - The sum of total dissolved solids and suspended solids.

total suspended particulates - Refers to the concentration of particulates in suspension in the air irrespective of the nature, source, or size of the particulates. 
turbidity - A measure of the concentration of sediment or suspended particles in solution.

upgradient-In the direction of increasing hydrostatic head.

vadose zone - Soil zone located above the water table.

volatile organic compounds - 1, 1, I -TCA, perclene, and triclene are common names for trichloroethane, tetrachloroethylene, and trichloroethylene, respectively. Used in many processes, the levels of these carcinogenic compounds must be kept to a minimum. They are measured by volatile organic analyses content.

watershed - The region draining into a river, river system, or body of water.

wetland - A lowland area, such as a marsh or swamp, inundated or saturated by surface or groundwater sufficiently to support hydrophytic vegetation typically adapted to life in saturated soils.

wind rose - A diagram in which statistical information concerning direction and speed of the wind at a location is summarized. 


\section{Paducah Site \\ 1995 Annual Environmental Report Data Volume}




\section{Data Volume}




\section{Radiological Effluent Monitoring}

Table 1.1 1995 Annual Radiological Data Summary for Outfall K017

\begin{tabular}{llccccc}
\hline \multicolumn{1}{c}{ Analysis } & Units & Minimum & Maximum & Average & Count & Rad Error \\
\hline$\%$ U-235 & $\mathrm{Wt} /$ & 0.472 & 0.472 & 0.472 & 4 & \\
Neptunium-237 & $\mathrm{pCi} / \mathrm{L}$ & -0.1 & 0.2 & 0.075 & 16 & 0.1 \\
Plutonium-239 & $\mathrm{pCi} / \mathrm{L}$ & 0 & 0.1 & 0.035 & 16 & 0.1 \\
Rad Alpha & $\mathrm{pCi} / \mathrm{ml}$ & 0.4 & 1.5 & 0.992857 & 42 & \\
Rad Beta & $\mathrm{pCi} / \mathrm{ml}$ & 1 & 1 & 1 & 42 & \\
Suspended Alpha & $\mathrm{pCi} / \mathrm{L}$ & -2.9 & 0.9 & -0.45 & 8 & 0.8 \\
Suspended Beta & $\mathrm{pCi} / \mathrm{L}$ & -1 & 4 & 1.25 & 8 & 3 \\
Technetium-99 & $\mathrm{pCi} / \mathrm{L}$ & 0 & 22 & 8 & 16 & 18 \\
Thorium-230 & $\mathrm{pCi} / \mathrm{L}$ & 0.1 & 0.3 & 0.15 & 16 & 0.1 \\
Uranium & $\mathrm{mg} / \mathrm{L}$ & 0.002 & 0.006 & 0.0035 & 16 & \\
Dissolved Alpha & $\mathrm{pCi} / \mathrm{L}$ & -4.2 & 5.5 & 1.45 & 8 & 3.2 \\
Dissolved Beta & $\mathrm{pCi} / \mathrm{L}$ & 3 & 24 & 10.25 & 8 & 6 \\
\hline
\end{tabular}

Table 1.2 1995 Annual Radiological Data Summary for Outfall K018

\begin{tabular}{lcccccc}
\hline \multicolumn{1}{c}{ Analysis } & Units & Minimum & Maximum & Average & Count & Rad Error \\
\hline \% U-235 & $\mathrm{Wt} \%$ & 0.378 & 0.668 & 0.55225 & 16 & \\
Neptunium-237 & $\mathrm{pCi} / \mathrm{L}$ & -0.3 & 0.6 & 0.125 & 16 & 0.3 \\
Plutonium-239 & $\mathrm{pCi} / \mathrm{L}$ & 0.07 & 0.1 & 0.0925 & 16 & \\
Rad Alpha & $\mathrm{pCi} / \mathrm{ml}$ & 0.4 & 1 & 0.92 & 45 & \\
Rad Beta & $\mathrm{pCi} / \mathrm{ml}$ & 1 & 1 & 1 & 45 & \\
Suspended Alpha & $\mathrm{pCi} / \mathrm{L}$ & -2.8 & 9.3 & 2.575 & 8 & 5.2 \\
Suspended Beta & $\mathrm{pCi} / \mathrm{L}$ & -2 & 14 & 4.25 & 8 & 3 \\
Technetium-99 & $\mathrm{pCi} / \mathrm{L}$ & 0 & 50 & 23.1818 & 44 & 98 \\
Thorium-230 & $\mathrm{pCi} / \mathrm{L}$ & 0 & 0.9 & 0.475 & 16 & 0.2 \\
Uranium & $\mathrm{mg} / \mathrm{L}$ & 0.002 & 0.015 & 0.007 & 44 & \\
Dissolved Alpha & $\mathrm{pCi} / \mathrm{L}$ & -2.7 & 15.7 & 6.15 & 8 & 6.4 \\
Dissolved Beta & $\mathrm{pCi} / \mathrm{L}$ & 12 & 33 & 18.5 & 8 & 7 \\
\hline
\end{tabular}




\section{Radiological Environmental Surveillance}

Table 2.1 1995 Annual Radiological Data Summary for Sampling Station SW1 Upstream Big Bayou Creek, Background

\begin{tabular}{lccccc}
\hline \multicolumn{1}{c}{ Analysis } & Units & Minimum & Maximum & Average & Count \\
\hline \% U-235 & $\mathrm{Wt} \%$ & 0.464 & 0.464 & 0.464 & 4 \\
Gross Alpha & $\mathrm{pCi} / \mathrm{L}$ & 0.3 & 1.2 & 0.725 & 12 \\
Gross Beta & $\mathrm{pCi} / \mathrm{L}$ & 2 & 11 & 6.25 & 12 \\
Gross Gamma & $\mathrm{pCi} / \mathrm{ml}$ & 0.0283 & 927.3 & 463.66415 & 2 \\
Neptunium-237 & $\mathrm{pCi} / \mathrm{L}$ & -0.5 & 0.9 & 0.146667 & 60 \\
Plutonium-239 & $\mathrm{pCi} / \mathrm{L}$ & 0 & 0.4 & 0.07588 & 60 \\
Rad Alpha & $\mathrm{pCi} / \mathrm{ml}$ & $<1$ & $<1$ & $<1$ & 18 \\
Rad Beta & $\mathrm{pCi} / \mathrm{ml}$ & $<1$ & $<1$ & $<1$ & 18 \\
Suspended Alpha & $\mathrm{pCi} / \mathrm{L}$ & -2.4 & 8.4 & 1.661538 & 26 \\
Suspended Beta & $\mathrm{pCi} / \mathrm{L}$ & 0 & 109 & 12.53846 & 26 \\
Technetium-99 & $\mathrm{pCi} / \mathrm{L}$ & 0 & 21 & 8.294118 & 68 \\
Thorium-230 & $\mathrm{pCi} / \mathrm{L}$ & 0 & 0.2 & 0.065 & 24 \\
Uranium & $\mathrm{mg} / \mathrm{L}$ & $<0.001$ & $<0.01$ & $<0.0015294$ & 68 \\
Dissolved Alpha & $\mathrm{pCi} / \mathrm{L}$ & -0.4 & 10.6 & 3.307692 & 26 \\
Dissolved Beta & $\mathrm{pCi} / \mathrm{L}$ & 3 & 156 & 19.61538 & 26 \\
\hline
\end{tabular}


Table 2.2 1995 Annual Radiological Data Summary for Sampling Station SW10 Downstream Little Bayou Creek

\begin{tabular}{lccccc}
\hline \multicolumn{1}{c}{ Analysis } & Units & Minimum & Maximum & Average & Count \\
\hline \% U-235 & $\mathrm{Wt} \%$ & 0.202 & 0.494 & 0.28572 & 44 \\
Gross Alpha & $\mathrm{pCi} / \mathrm{L}$ & 2 & 4.4 & 3.06667 & 9 \\
Gross Beta & $\mathrm{pCi} / \mathrm{L}$ & 6 & 10 & 7.33333 & 9 \\
Neptunium-237 & $\mathrm{pCi} / \mathrm{L}$ & -0.5 & 1.1 & 0.26667 & 48 \\
Plutonium-239 & $\mathrm{pCi} / \mathrm{L}$ & 0 & 0.1 & 0.05585 & 52 \\
Suspended Alpha & $\mathrm{pCi} / \mathrm{L}$ & -15.6 & 5.7 & -1.01 & 20 \\
Suspended Beta & $\mathrm{pCi} / \mathrm{L}$ & 1 & 14 & 5.6 & 20 \\
Technetium-99 & $\mathrm{pCi} / \mathrm{L}$ & 0 & 32 & 9.384615 & 52 \\
Thorium-230 & $\mathrm{pCi} / \mathrm{L}$ & 0 & 0.2 & 0.1025 & 16 \\
Uranium & $\mathrm{mg} / \mathrm{L}$ & 0.003 & 0.028 & 0.011846 & 52 \\
Dissolved Alpha & $\mathrm{pCi} / \mathrm{L}$ & 0.3 & 48.1 & 9.2 & 20 \\
Dissolved Beta & $\mathrm{pCi} / \mathrm{L}$ & 8 & 21 & 13.4 & 20 \\
\hline
\end{tabular}

Table 2.3 1995 Annual Radiological Data Summary for Sampling Station SW29 Upstream Ohio River

\begin{tabular}{lccccc}
\hline \multicolumn{1}{c}{ Analysis } & $\mathrm{Units}$ & Minimum & Maximum & Average & Count \\
\hline \% U-235 & $\mathrm{Wt} \%$ & 0.713 & 0.713 & 0.713 & 4 \\
Gross Alpha & $\mathrm{pCi} / \mathrm{L}$ & -0.3 & -0.3 & -0.3 & 3 \\
Gross Beta & $\mathrm{pCi} / \mathrm{L}$ & 2 & 2 & 2 & 3 \\
Gross Gamma & $\mathrm{pCi} / \mathrm{ml}$ & 81.04 & 81.04 & 81.04 & 1 \\
Neptunium-237 & $\mathrm{pCi} / \mathrm{L}$ & -0.7 & 0.4 & 0.0769 & 52 \\
Plutonium-239 & $\mathrm{pCi} / \mathrm{L}$ & 0 & 0.1 & 0.0613 & 48 \\
Rad Alpha & $\mathrm{pCi} / \mathrm{ml}$ & $<1$ & $<1$ & $<1$ & 6 \\
Rad Beta & $\mathrm{pCi} / \mathrm{ml}$ & $<1$ & $<1$ & $<1$ & 6 \\
Suspended Alpha & $\mathrm{pCi} / \mathrm{L}$ & -1 & 9.7 & 2.7214 & 28 \\
Suspended Beta & $\mathrm{pCi} / \mathrm{L}$ & -3 & 94 & 12.9285 & 28 \\
Technetium-99 & $\mathrm{pCi} / \mathrm{L}$ & 0 & 21 & 7.6923 & 52 \\
Thorium-230 & $\mathrm{pCi} / \mathrm{L}$ & 0.02 & 0.1 & 0.05667 & 12 \\
Uranium & $\mathrm{mg} / \mathrm{L}$ & $<0.001$ & $<0.001$ & $<0.001$ & 56 \\
Dissolved Alpha & $\mathrm{pCi} / \mathrm{L}$ & -1.5 & 6.6 & 2.37857 & 28 \\
Dissolved Beta & $\mathrm{pCi} / \mathrm{L}$ & -3 & 234 & 23.5714 & 28 \\
\hline
\end{tabular}


Table 2.4 1995 Annual Radiological Data Summary for Sampling Station SW3

\begin{tabular}{lccccc}
\hline \multicolumn{1}{c}{ Analysis } & Units & Minimum & Maximum & Average & Count \\
\hline \% U-235 & $\mathrm{Wt} \%$ & 0.644 & 0.644 & 0.644 & 4 \\
Gross Gamma & $\mathrm{pCi} / \mathrm{ml}$ & 283.7 & 283.7 & 283.7 & 1 \\
Neptunium-237 & $\mathrm{pCi} / \mathrm{L}$ & -0.5 & 0.7 & 0.1 & 8 \\
Plutonium-239 & $\mathrm{pCi} / \mathrm{L}$ & 0.09 & 0.1 & 0.095 & 8 \\
Rad Alpha & $\mathrm{pCi} / \mathrm{ml}$ & $<1$ & $<1$ & $<1$ & 6 \\
Rad Beta & $\mathrm{pCi} / \mathrm{ml}$ & $<1$ & $<1$ & $<1$ & 6 \\
Suspended Alpha & $\mathrm{pCi} / \mathrm{L}$ & 1 & 1.9 & 1.45 & 4 \\
Suspended Beta & $\mathrm{pCi} / \mathrm{L}$ & -2 & 21 & 9.5 & 4 \\
Technetium-99 & $\mathrm{pCi} / \mathrm{L}$ & 2 & 23 & 12.5 & 8 \\
Thorium-230 & $\mathrm{pCi} / \mathrm{L}$ & 0.03 & 0.1 & 0.065 & 8 \\
Uranium & $\mathrm{mg} / \mathrm{L}$ & 0.002 & 0.008 & 0.005 & 8 \\
Uranium-238 & $\mathrm{pCi} / \mathrm{L}$ & 0.33 & 0.33 & 0.33 & 4 \\
Dissolved Alpha & $\mathrm{pCi} / \mathrm{L}$ & 2.9 & 6.8 & 4.85 & 4 \\
Dissolved Beta & $\mathrm{pCi} / \mathrm{L}$ & 6 & 6 & 6 & 4 \\
\hline
\end{tabular}

Table 2.5 1995 Annual Radiological Data Summary for Sampling Station SW30 Downstream Ohio River

\begin{tabular}{lccccc}
\hline \multicolumn{1}{c}{ Analysis } & Units & Minimum & Maximum & Average & Count \\
\hline \% U-235 & $\mathrm{Wt} \%$ & 0.424 & 0.735 & 0.5795 & 8 \\
Gross Alpha & $\mathrm{pCi} / \mathrm{L}$ & 3.6 & 3.6 & 3.6 & 3 \\
Gross Beta & $\mathrm{pCi} / \mathrm{L}$ & 6 & 6 & 6 & 3 \\
Neptunium-237 & $\mathrm{pCi} / \mathrm{L}$ & -0.5 & 0.8 & 0.31111 & 36 \\
Plutonium-239 & $\mathrm{pCi} / \mathrm{L}$ & 0 & 0.1 & 0.0591 & 32 \\
Suspended Alpha & $\mathrm{pCi} / \mathrm{L}$ & 0.6 & 9.3 & 3.32 & 20 \\
Suspended Beta & $\mathrm{pCi} / \mathrm{L}$ & -2 & 12 & 4.1 & 20 \\
Technetium-99 & $\mathrm{pCi} / \mathrm{L}$ & 0 & 21 & 5.25 & 32 \\
Thorium-230 & $\mathrm{pCi} / \mathrm{L}$ & 0.1 & 0.1 & 0.1 & 4 \\
Uranium & $\mathrm{mg} / \mathrm{L}$ & 0.001 & 0.002 & 0.00111 & 36 \\
Dissolved Alpha & $\mathrm{pCi} / \mathrm{L}$ & 0.9 & 14.4 & 5.05 & 20 \\
Dissolved Beta & $\mathrm{pCi} / \mathrm{L}$ & 4 & 17 & 8 & 20 \\
\hline
\end{tabular}


Table 2.6 1995 Annual Radiological Data Summary for Sampling Station SW4

\begin{tabular}{lccccc}
\hline \multicolumn{1}{c}{ Analysis } & Units & Minimum & Maximum & Average & Count \\
\hline Gross Gamma & $\mathrm{pCi} / \mathrm{ml}$ & 0.0274 & 414.9 & 207.4637 & 2 \\
Neptunium-237 & $\mathrm{pCi} / \mathrm{L}$ & -0.2 & -0.1 & -0.15 & 8 \\
Plutonium-239 & $\mathrm{pCi} / \mathrm{L}$ & 0.09 & 0.1 & 0.095 & 8 \\
Rad Alpha & $\mathrm{pCi} / \mathrm{ml}$ & $<1$ & $<1$ & $<1$ & 15 \\
Rad Beta & $\mathrm{pCi} / \mathrm{ml}$ & $<1$ & $<1$ & $<1$ & 15 \\
Suspended Alpha & $\mathrm{pCi} / \mathrm{L}$ & 1 & 3.4 & 2.2 & 4 \\
Suspended Beta & $\mathrm{pCi} / \mathrm{L}$ & -1 & 5 & 2 & 4 \\
Technetium-99 & $\mathrm{pCi} / \mathrm{L}$ & 4 & 14 & 9 & 8 \\
Thorium-230 & $\mathrm{pCi} / \mathrm{L}$ & 0.04 & 0.1 & 0.07 & 8 \\
Uranium & $\mathrm{mg} / \mathrm{L}$ & 0.001 & 0.004 & 0.0025 & 8 \\
Dissolved Alpha & $\mathrm{pCi} / \mathrm{L}$ & -0.1 & 4.3 & 2.1 & 4 \\
Dissolved Beta & $\mathrm{pCi} / \mathrm{L}$ & 11 & 21 & 16 & 4 \\
\hline
\end{tabular}

Table 2.7 1995 Annual Radiological Data Summary for Sampling Station SW5 Downstream Big Bayou

\begin{tabular}{lccccc}
\hline \multicolumn{1}{c}{ Analysis } & Units & Minimum & Maximum & Average & Count \\
\hline \% U-235 & $\mathrm{Wt} \%$ & 0.316 & 0.698 & 0.511 & 12 \\
Gross Alpha & $\mathrm{pCi} / \mathrm{L}$ & -0.9 & 4.9 & 2.1 & 9 \\
Gross Beta & $\mathrm{pCi} / \mathrm{L}$ & 21 & 34 & 27 & 9 \\
Gross Gamma & $\mathrm{pCi} / \mathrm{ml}$ & 6.733 & 6.733 & 6.733 & 1 \\
Neptunium-237 & $\mathrm{pCi} / \mathrm{L}$ & -0.7 & 0.6 & 0.04375 & 64 \\
Plutonium-239 & $\mathrm{pCi} / \mathrm{L}$ & 0 & 0.1 & 0.05593125 & 64 \\
Rad Alpha & $\mathrm{pCi} / \mathrm{ml}$ & $<1$ & $<1$ & $<1$ & 9 \\
Rad Beta & $\mathrm{pCi} / \mathrm{ml}$ & $<1$ & $<1$ & $<1$ & 9 \\
Suspended Alpha & $\mathrm{pCi} / \mathrm{L}$ & -0.3 & 8.8 & 2.107692308 & 26 \\
Suspended Beta & $\mathrm{pCi} / \mathrm{L}$ & -3 & 15 & 2.923076923 & 26 \\
Technetium-99 & $\mathrm{pCi} / \mathrm{L}$ & 0 & 25 & 11.4375 & 64 \\
Thorium-230 & $\mathrm{pCi} / \mathrm{L}$ & 0 & 0.2 & 0.08 & 28 \\
Uranium & $\mathrm{mg} / \mathrm{L}$ & 0.001 & 0.02 & 0.004125 & 64 \\
Dissolved Alpha & $\mathrm{pCi} / \mathrm{L}$ & -0.6 & 9.4 & 2.7 & 26 \\
Dissolved Beta & $\mathrm{pCi} / \mathrm{L}$ & -3 & 45 & 18.23076923 & 26 \\
\hline
\end{tabular}


Table 2.8 1995 Annual Radiological Data Summary for Sampling Station SW64 Downstream Big Bayou

\begin{tabular}{lccccc}
\hline \multicolumn{1}{c}{ Analysis } & Units & Minimum & Maximum & Average & Count \\
\hline Gross Alpha & $\mathrm{pCi} / \mathrm{L}$ & -0.3 & 1.2 & 0.45 & 6 \\
Gross Beta & $\mathrm{pCi} / \mathrm{L}$ & 4 & 10 & 7 & 6 \\
Gross Gamma & $\mathrm{pCi} / \mathrm{ml}$ & 0.0216 & 153.7 & 76.8608 & 2 \\
Neptunium-237 & $\mathrm{pCi} / \mathrm{L}$ & -0.5 & -0.2 & -0.35 & 8 \\
Plutonium-239 & $\mathrm{pCi} / \mathrm{L}$ & 0.05 & 0.1 & 0.075 & 8 \\
Rad Alpha & $\mathrm{pCi} / \mathrm{ml}$ & $<1$ & $<1$ & $<1$ & 6 \\
Rad Beta & $\mathrm{pCi} / \mathrm{ml}$ & $<1$ & $<1$ & $<1$ & 6 \\
Suspended Alpha & $\mathrm{pCi} / \mathrm{L}$ & 0.2 & 2.3 & 1.25 & 4 \\
Suspended Beta & $\mathrm{pCi} / \mathrm{L}$ & -2 & 7 & 2.5 & 4 \\
Technetium-99 & $\mathrm{pCi} / \mathrm{L}$ & 0 & 11 & 4.25 & 16 \\
Thorium-230 & $\mathrm{pCi} / \mathrm{L}$ & 0.05 & 0.1 & 0.075 & 8 \\
Uranium & $\mathrm{mg} / \mathrm{L}$ & $<0.001$ & $<0.001$ & $<0.001$ & 16 \\
Dissolved Alpha & $\mathrm{pCi} / \mathrm{L}$ & 0 & 2.2 & 1.1 & 4 \\
Dissolved Beta & $\mathrm{pCi} / \mathrm{L}$ & -1 & 0 & -0.5 & 4 \\
\hline
\end{tabular}




\section{Dose}

Table 3.1 Internal Dose Factors for an Adult

\begin{tabular}{cccccc}
\hline & & \multicolumn{5}{c}{$\begin{array}{c}\text { Intake }^{a} \\
\text { (mrem/pCi) }\end{array}$} \\
\cline { 3 - 6 } Radionuclide & $\begin{array}{c}\text { Half-life } \\
\text { (years) }\end{array}$ & $\begin{array}{c}\text { Inhalation }^{b} \\
\text { (soluble) }\end{array}$ & $\begin{array}{c}\text { Inhalation } \\
\text { (slightly } \\
\text { soluble) }\end{array}$ & $\begin{array}{c}\text { Inhalation }{ }^{b} \\
\text { (insoluble) }\end{array}$ & Ingestion \\
\hline${ }^{234} \mathrm{U}$ & 240,000 & 0.0027 & 0.0071 & 0.13 & 0.00026 \\
${ }^{235} \mathrm{U}$ & $710,000,000$ & 0.0025 & 0.0067 & 0.12 & 0.00025 \\
${ }^{238} \mathrm{U}$ & $4,500,000,000$ & 0.0024 & 0.0062 & 0.12 & 0.00023 \\
${ }^{99} \mathrm{Tc}$ & 210,000 & 0.00000084 & 0.0000075 & 0.0000013 \\
${ }^{237} \mathrm{~Np}$ & $2,100,000$ & & 0.49 & 0.0039 \\
${ }^{239} \mathrm{Pu}$ & 24,000 & & 0.51 & 0.33 & 0.0043 \\
${ }^{230} \mathrm{Th}$ & 75,000 & & 0.32 & 0.26 & 0.00053 \\
\hline
\end{tabular}

${ }^{a}$ Source: U.S. DOE. July 1988. Internal Dose Conversion Factors for Calculations of Dose to the Public, DOE/EH-0071, U.S. DOE.

${ }^{b}$ Includes allowance for skin absorption. 


\section{Nonradiological Effluent Monitoring}

Table 4.1 Compliance Experience under Interim KPDES Limits for 1995 Maximum daily limits at outfalls 017 and 018

\begin{tabular}{|c|c|c|}
\hline Permitted Parameters & 017 & 018 \\
\hline Aluminum (mg/L) & $\mathrm{M}^{a}$ & M \\
\hline Cadmium (mg/L) & 0.004 & 0.004 \\
\hline Chromium (mg/L) & 0.016 & 0.016 \\
\hline Copper $(\mathrm{mg} / \mathrm{L})$ & 0.018 & 0.018 \\
\hline Dissolved alpha (pCi/L) & $\mathrm{NR}^{b}$ & NR \\
\hline Dissolved beta $(\mathrm{pCi} / \mathrm{L})$ & NR & NR \\
\hline Flow (Mgd) & M & M \\
\hline Hardness as $\left.\mathrm{CaCO}_{3}(\mathrm{mg} / \mathrm{L} \mathrm{CaCO})_{3}\right)$ & M & M \\
\hline Iron $(\mathrm{mg} / \mathrm{L})$ & $\mathbf{M}$ & $\mathbf{M}$ \\
\hline Lead $(\mathrm{mg} / \mathrm{L})$ & 0.082 & 0.082 \\
\hline Nickel (mg/L) & 1.418 & 1.418 \\
\hline Oil and Grease $(\mathrm{mg} / \mathrm{L})$ & 15 & 15 \\
\hline $\mathrm{PCB}(\mu \mathrm{g} / \mathrm{L})$ & 0.0001 & 0.0001 \\
\hline $\mathrm{pH}(\mathrm{SU})$ & 9 & 9 \\
\hline Suspended alpha (pCi/L) & NR & NR \\
\hline Suspended beta $(\mathrm{pCi} / \mathrm{L})$ & NR & NR \\
\hline Total suspended solids $(\mathrm{mg} / \mathrm{L})$ & M & M \\
\hline Toxicity (TUc) & NR & NR \\
\hline Trichloroethylene $(\mu \mathrm{g} / \mathrm{L})$ & 81 & 81 \\
\hline Uranium (mg/L) & NR & $\mathrm{NR}$ \\
\hline Zinc (mg/L) & 0.117 & 0.117 \\
\hline
\end{tabular}

${ }^{a}$ Duplicate injection precision not met.

${ }^{b}$ No result available or not required because total analyses were less than practical quantitation level. 
Table 4.2 Compliance Experience under Interim KPDES Limits for 1995 Maximum daily limits for TCE at outfalls 017 and 018

\begin{tabular}{lll}
\hline Outfall & Frequency & TCE Limit $(\mu \mathrm{g} / \mathrm{L})$ \\
\hline 017 & Monthly & 81 \\
018 & Monthly & 81 \\
\hline
\end{tabular}

${ }^{a}$ Duplicate injection precision not met.

Table 4.3 1995 Nonradiological Data Summary for Outfall 017

\begin{tabular}{lccccc}
\hline \multicolumn{1}{c}{ Analysis } & Units & Minimum & Maximum & Average & Count \\
\hline Hardness as CaCO3 & $\mathrm{mg} / \mathrm{L} \mathrm{CaCO} 3$ & 68 & 198 & 148 & 22 \\
Aluminum & $\mathrm{mg} / \mathrm{L}$ & 0.394 & 3.1 & 0.969 & 33 \\
Cadmium & $\mathrm{mg} / \mathrm{L}$ & $<0.0005$ & 0.001 & $<0.0009$ & 33 \\
Chromium & $\mathrm{mg} / \mathrm{L}$ & $<0.006$ & $<0.011$ & $<0.009$ & 33 \\
Copper & $\mathrm{mg} / \mathrm{L}$ & $<0.01$ & $<0.012$ & $<0.012$ & 33 \\
Iron & $\mathrm{mg} / \mathrm{L}$ & 0.257 & 2.86 & 0.862 & 33 \\
Lead & $\mathrm{mg} / \mathrm{L}$ & $<0.003$ & $<0.003$ & $<0.003$ & 44 \\
Nickel & $\mathrm{mg} / \mathrm{L}$ & $<0.05$ & $<0.05$ & $<0.05$ & 33 \\
Zinc & $\mathrm{mg} / \mathrm{L}$ & $<0.015$ & 0.042 & $<0.0225$ & 33 \\
Flow & $\mathrm{MGD}$ & $<0.002$ & 2.86 & $<0.3765$ & 11 \\
Oil and Grease & $\mathrm{mg} / \mathrm{L}$ & $<5$ & $<5$ & $<5$ & 11 \\
pH & $\mathrm{SU}$ & 7.5 & 8.1 & 7.8 & 22 \\
Total Suspended Solids & $\mathrm{mg} / \mathrm{L}$ & $<4$ & 35 & $<13$ & 11 \\
PCB & $\mu \mathrm{g} / \mathrm{L}$ & $<0.17$ & $<0.17$ & $<0.17$ & 33 \\
Trichloroethene & $\mu \mathrm{g} / \mathrm{L}$ & 1 & 1 & 1 & 33 \\
\hline
\end{tabular}


Table 4.4 1995 Nonradiological Data Summary for Outfall 018

\begin{tabular}{cccccc}
\hline Analysis & Units & Minimum & Maximum & Average & Count \\
\hline Hardness as CaCO3 & $\mathrm{mg} / \mathrm{L} \mathrm{CaCO} 3$ & 44 & 180 & 93.8 & 22 \\
Aluminum & $\mathrm{mg} / \mathrm{L}$ & 0.905 & 530 & 55.508 & 33 \\
Cadmium & $\mathrm{mg} / \mathrm{L}$ & $<0.0005$ & 0.001 & $<0.0009$ & 33 \\
Chromium & $\mathrm{mg} / \mathrm{L}$ & $<0.006$ & 0.032 & $<0.012$ & 33 \\
Copper & $\mathrm{mg} / \mathrm{L}$ & $<0.01$ & 0.038 & $<0.018$ & 33 \\
Iron & $\mathrm{mg} / \mathrm{L}$ & 0.79 & 520 & 54 & 33 \\
Lead & $\mathrm{mg} / \mathrm{L}$ & $<0.003$ & 0.154 & $<0.018$ & 44 \\
Nickel & $\mathrm{mg} / \mathrm{L}$ & $<0.05$ & 0.307 & $<0.073$ & 33 \\
Zinc & $\mathrm{mg} / \mathrm{L}$ & $<0.02$ & 0.153 & $<0.049$ & 33 \\
Flow & $\mathrm{MGD}$ & 0.032 & 9.5 & 1.696 & 11 \\
Oil and Grease & $\mathrm{mg} / \mathrm{L}$ & $<5$ & $<5$ & $<5$ & 11 \\
pH & $\mathrm{SU}$ & 5.8 & 7.8 & 7.4 & 22 \\
Total Suspended & $\mathrm{mg} / \mathrm{L}$ & 7 & 6000 & 717 & 11 \\
Solids & & & & & \\
PCB & $\mu \mathrm{g} / \mathrm{L}$ & $<0.17$ & $<0.17$ & $<0.17$ & 36 \\
Trichloroethene & $\mu \mathrm{g} / \mathrm{L}$ & 1 & 1 & 1 & 33 \\
\hline
\end{tabular}




\section{Nonradiological Environmental Monitoring}

Table 5.1 1995 Nonradiological Data Summary for Surface Water Location SW1

\begin{tabular}{|c|c|c|c|c|c|}
\hline Analysis & Units & Minimum & Maximum & Average & Count \\
\hline Chloride & $\mathrm{mg} / \mathrm{L}$ & 3.4 & 18.4 & 14.1 & 33 \\
\hline Fluoride & $\mathrm{mg} / \mathrm{L}$ & 0.11 & 0.19 & 0.14 & 44 \\
\hline Hardness as $\mathrm{CaCO} 3$ & $\mathrm{mg} / \mathrm{L} \mathrm{CaCO} 3$ & 56 & 59 & 57.5 & 4 \\
\hline Nitrate as Nitrogen & $\mathrm{mg} / \mathrm{L}$ & $<1$ & 4 & $<1.3$ & 30 \\
\hline Phosphate as $\mathrm{P}$ & $\mathrm{mg} / \mathrm{L}$ & $<2$ & $<2$ & $<2$ & 30 \\
\hline Sulfate & $\mathrm{mg} / \mathrm{L}$ & 9.3 & 44.8 & 23.79 & 30 \\
\hline Hexavalent Chromium & $\mathrm{mg} / \mathrm{L}$ & $<0.01$ & $<0.01$ & $<0.01$ & 36 \\
\hline Arsenic & $\mathrm{mg} / \mathrm{L}$ & $<0.005$ & $<0.005$ & $<0.005$ & 6 \\
\hline Mercury & $\mathrm{mg} / \mathrm{L}$ & $<0.0002$ & $<0.0002$ & $<0.0002$ & 6 \\
\hline Selenium & $\mathrm{mg} / \mathrm{L}$ & $<0.005$ & 0.015 & $<0.01$ & 6 \\
\hline Aluminum & $\mathrm{mg} / \mathrm{L}$ & $<0.312$ & $<0.312$ & $<0.312$ & 9 \\
\hline Antimony & $\mathrm{mg} / \mathrm{L}$ & $<0.09$ & $<0.092$ & $<0.091$ & $\because 6$ \\
\hline Barium & $\mathrm{mg} / \mathrm{L}$ & 0.05 & 0.07 & 0.06 & 6 \\
\hline Beryllium & $\mathrm{mg} / \mathrm{L}$ & $<0.008$ & $<0.01$ & $<0.009$ & 6 \\
\hline Cadmium & $\mathrm{mg} / \mathrm{L}$ & $<0.001$ & $<0.001$ & $<0.001$ & 15 \\
\hline Calcium & $\mathrm{mg} / \mathrm{L}$ & 14.68 & 31 & 22.84 & 6 \\
\hline Chromium & $\mathrm{mg} / \mathrm{L}$ & $<0.01$ & 0.011 & $<0.0108$ & 15 \\
\hline Cobalt & $\mathrm{mg} / \mathrm{L}$ & $<0.02$ & $<0.022$ & $<0.021$ & 6 \\
\hline Copper & $\mathrm{mg} / \mathrm{L}$ & $<0.01$ & 0.012 & $<0.0116$ & 15 \\
\hline Iron & $\mathrm{mg} / \mathrm{L}$ & 0.453 & 1.29 & 0.9696 & 15 \\
\hline Lead & $\mathrm{mg} / \mathrm{L}$ & $<0.003$ & $<0.003$ & $<0.003$ & 20 \\
\hline Magnesium & $\mathrm{mg} / \mathrm{L}$ & 3.66 & 4.1 & 3.88 & 6 \\
\hline Manganese & $\mathrm{mg} / \mathrm{L}$ & 0.615 & 1.5 & 1.0575 & 6 \\
\hline Nickel & $\mathrm{mg} / \mathrm{L}$ & $<0.05$ & $<0.05$ & $<0.05$ & 15 \\
\hline Phosphorus (P) & $\mathrm{mg} / \mathrm{L}$ & $<0.05$ & 0.08 & $<0.067$ & 9 \\
\hline Potassium & $\mathrm{mg} / \mathrm{L}$ & $<3.04$ & $<10.5$ & $<6.77$ & 6 \\
\hline Silver & $\mathrm{mg} / \mathrm{L}$ & $<0.03$ & 0.06 & $<0.045$ & 6 \\
\hline Zinc & $\mathrm{mg} / \mathrm{L}$ & $<0.015$ & 0.024 & $<0.0178$ & 15 \\
\hline BOD & $\mathrm{mg} / \mathrm{L}$ & $<5$ & $<5$ & $<5$ & 3 \\
\hline $\mathrm{pH}$ & su & 6.9 & 7.6 & 7.23 & 28 \\
\hline Temperature & $\mathbf{F}$ & 34 & 81 & 59.26 & 65 \\
\hline Total Suspended Solids & $\mathrm{mg} / \mathrm{L}$ & $<4$ & 8 & $<5.33$ & 3 \\
\hline PCB & $\mathrm{ug} / \mathrm{L}$ & $<0.1$ & $<0.17$ & $<0.156$ & 15 \\
\hline Acetone & $\mathrm{ug} / \mathrm{L}$ & $<1000$ & $<1000$ & $<1000$ & 9 \\
\hline Isopropanol & $\mathrm{ug} / \mathrm{L}$ & $<1000$ & $<1000$ & $<1000$ & 9 \\
\hline Trichloroethene & $\mathrm{ug} / \mathrm{L}$ & 1 & 1 & 1 & 9 \\
\hline
\end{tabular}


Table 5.2 1995 Nonradiological Data Summary for Surface Water Location SW29

\begin{tabular}{|c|c|c|c|c|c|}
\hline Analysis & Units & Minimum & Maximum & Average & Count \\
\hline Chloride & $\mathrm{mg} / \mathrm{L}$ & 4.6 & 17.7 & 11.14167 & 36 \\
\hline Fluoride & $\mathrm{mg} / \mathrm{L}$ & $<0.1$ & 0.14 & $<0.116$ & 44 \\
\hline Hardness as $\mathrm{CaCO} 3$ & $\mathrm{mg} / \mathrm{L} \mathrm{CaCO} 3$ & 104 & 104 & 104 & 2 \\
\hline Nitrate as Nitrogen & $\mathrm{mg} / \mathrm{L}$ & $<1$ & 3.1 & $<1.23$ & 33 \\
\hline Phosphate as $\mathrm{P}$ & $\mathrm{mg} / \mathrm{L}$ & $<0.1$ & 2 & $<1.827$ & 33 \\
\hline Sulfate & $\mathrm{mg} / \mathrm{L}$ & 10.2 & 47.3 & 25.5636 & 33 \\
\hline Hexavalent Chromium & $\mathrm{mg} / \mathrm{L}$ & $<0.01$ & $<0.01$ & $<0.01$ & 36 \\
\hline Aluminum & $\mathrm{mg} / \mathrm{L}$ & 0.412 & 0.715 & 0.5635 & 6 \\
\hline Cadmium & $\mathrm{mg} / \mathrm{L}$ & $<0.001$ & $<0.001$ & $<0.001$ & 6 \\
\hline Chromium & $\mathrm{mg} / \mathrm{L}$ & $<0.011$ & $<0.011$ & $<0.011$ & 6 \\
\hline Copper & $\mathrm{mg} / \mathrm{L}$ & $<0.012$ & $<0.012$ & $<0.012$ & 6 \\
\hline Iron & $\mathrm{mg} / \mathrm{L}$ & 0.374 & 0.88 & 0.627 & 6 \\
\hline Lead & $\mathrm{mg} / \mathrm{L}$ & $<0.003$ & $<0.003$ & $<0.003$ & 8 \\
\hline Nickel & $\mathrm{mg} / \mathrm{L}$ & $<0.05$ & $<0.05$ & $<0.05$ & 6 \\
\hline Phosphorus $(\mathrm{P})$ & $\mathrm{mg} / \mathrm{L}$ & 0.07 & 0.1 & 0.085 & 6 \\
\hline Zinc & $\mathrm{mg} / \mathrm{L}$ & $<0.015$ & 0.025 & $<0.02$ & 6 \\
\hline BOD & $\mathrm{mg} / \mathrm{L}$ & 5 & 5 & 5 & 2 \\
\hline $\mathrm{pH}$ & SU & 7.4 & 8 & 7.65714 & 28 \\
\hline Temperature & $F$ & 47 & 70 & 58.5 & 2 \\
\hline $\begin{array}{l}\text { Total Suspended } \\
\text { Solids }\end{array}$ & $\mathrm{mg} / \mathrm{L}$ & 7 & 22 & 14.5 & 2 \\
\hline PCB & $\mu \mathrm{g} / \mathrm{L}$ & $<0.17$ & $<0.17$ & $<0.17$ & 6 \\
\hline Acetone & $\mu \mathrm{g} / \mathrm{L}$ & $<1000$ & $<1000$ & $<1000$ & 6 \\
\hline Isopropanol & $\mu \mathrm{g} / \mathrm{L}$ & $<1000$ & $<1000$ & $<1000$ & 6 \\
\hline Trichloroethene & $\mu \mathrm{g} / \mathrm{L}$ & 1 & 1 & 1 & 6 \\
\hline
\end{tabular}


Table 5.3 1995 Nonradiological Data Summary for Surface Water Location SW3

\begin{tabular}{cccccc}
\hline Analysis & $\mathrm{Units}$ & Minimum & Maximum & Average & Count \\
\hline Chloride & $\mathrm{mg} / \mathrm{L}$ & 20.3 & 157.7 & 89 & 6 \\
Hardness as CaCO3 & $\mathrm{mg} / \mathrm{L}$ & 62 & 62 & 62 & 2 \\
& $\mathrm{CaCO} 3$ & & & & \\
Aluminum & $\mathrm{mg} / \mathrm{L}$ & $<0.312$ & $<0.312$ & $<0.312$ & 6 \\
Cadmium & $\mathrm{mg} / \mathrm{L}$ & $<0.001$ & $<0.001$ & $<0.001$ & 6 \\
Chromium & $\mathrm{mg} / \mathrm{L}$ & $<0.011$ & 0.019 & $<0.015$ & 6 \\
Copper & $\mathrm{mg} / \mathrm{L}$ & $<0.012$ & $<0.012$ & $<0.012$ & 6 \\
Iron & $\mathrm{mg} / \mathrm{L}$ & 0.24 & 0.278 & 0.259 & 6 \\
Lead & $\mathrm{mg} / \mathrm{L}$ & $<0.003$ & $<0.003$ & $<0.003$ & 8 \\
Nickel & $\mathrm{mg} / \mathrm{L}$ & $<0.05$ & $<0.05$ & $<0.05$ & 6 \\
Phosphorus $(\mathrm{P})$ & $\mathrm{mg} / \mathrm{L}$ & 0.38 & 0.44 & 0.41 & 6 \\
Zinc & $\mathrm{mg} / \mathrm{L}$ & 0.02 & 0.034 & 0.027 & 6 \\
BOD & $\mathrm{mg} / \mathrm{L}$ & $<5$ & $<5$ & $<5$ & 2 \\
pH & $\mathrm{SU}$ & 7.4 & 7.5 & 7.45 & 4 \\
Temperature & $\mathrm{F}$ & 54 & 75 & 64.5 & 2 \\
Total Suspended & $\mathrm{mg} / \mathrm{L}$ & $<4$ & 5 & $<4.5$ & 2 \\
Solids & & & & & \\
PCB & $\mu \mathrm{g} / \mathrm{L}$ & $<0.17$ & $<0.17$ & $<0.17$ & 6 \\
Acetone & $\mu \mathrm{g} / \mathrm{L}$ & $<1000$ & $<1000$ & $<1000$ & 6 \\
Isopropanol & $\mu \mathrm{g} / \mathrm{L}$ & $<1000$ & $<1000$ & $<1000$ & 6 \\
Trichloroethene & $\mu \mathrm{g} / \mathrm{L}$ & 1 & 1 & 1 & 6 \\
\hline & & & & &
\end{tabular}


Table 5.4 1995 Nonradiological Data Summary for Surface Water Location SW30

\begin{tabular}{cccccc}
\hline Analysis & Units & Minimum & Maximum & Average & Count \\
\hline Chloride & $\mathrm{mg} / \mathrm{L}$ & 7 & 17 & 12.1 & 21 \\
Fluoride & $\mathrm{mg} / \mathrm{L}$ & $<0.1$ & 0.14 & $<0.1222$ & 36 \\
Nitrate as Nitrogen & $\mathrm{mg} / \mathrm{L}$ & $<1$ & 4 & $<1.6667$ & 27 \\
Phosphate as $\mathrm{P}$ & $\mathrm{mg} / \mathrm{L}$ & $<0.1$ & 2 & $<1.7889$ & 27 \\
Sulfate & $\mathrm{mg} / \mathrm{L}$ & 17.5 & 45 & 29.767 & 27 \\
Hexavalent & $\mathrm{mg} / \mathrm{L}$ & $<0.01$ & $<0.01$ & $<0.01$ & 30 \\
Chromium & & & & & \\
pH & $\mathrm{SU}$ & 7.3 & 7.6 & 7.44 & 20 \\
Temperature & $\mathrm{F}$ & 45 & 45 & 45 & 1 \\
1,2-Dichloroethane & $\mu \mathrm{g} / \mathrm{L}$ & 1 & 5 & 1.5 & 24 \\
Trichloroethene & $\mu \mathrm{g} / \mathrm{L}$ & 1 & 1 & 1 & 3 \\
\hline
\end{tabular}

Table 5.5 1995 Nonradiological Data Summary for Surface Water Location SW4

\begin{tabular}{cccccc}
\hline Analysis & Units & Minimum & Maximum & Average & Count \\
\hline Chloride & $\mathrm{mg} / \mathrm{L}$ & 17.7 & 75.1 & 46.4 & 6 \\
Hardness as CaCO3 & $\mathrm{mg} / \mathrm{L} \mathrm{CaCO} 3$ & 172 & 172 & 172 & 2 \\
Aluminum & $\mathrm{mg} / \mathrm{L}$ & $<0.312$ & $<0.312$ & $<0.312$ & 6 \\
Cadmium & $\mathrm{mg} / \mathrm{L}$ & $<0.001$ & $<0.001$ & $<0.001$ & 6 \\
Chromium & $\mathrm{mg} / \mathrm{L}$ & $<0.011$ & $<0.011$ & $<0.011$ & 6 \\
Copper & $\mathrm{mg} / \mathrm{L}$ & $<0.012$ & $<0.012$ & $<0.012$ & 6 \\
Iron & $\mathrm{mg} / \mathrm{L}$ & 0.279 & 0.287 & 0.283 & 6 \\
Lead & $\mathrm{mg} / \mathrm{L}$ & $<0.003$ & $<0.003$ & $<0.003$ & 8 \\
Nickel & $\mathrm{mg} / \mathrm{L}$ & $<0.05$ & $<0.05$ & $<0.05$ & 6 \\
Phosphorus $(\mathrm{P})$ & $\mathrm{mg} / \mathrm{L}$ & 0.27 & 0.27 & 0.27 & 6 \\
Zinc & $\mathrm{mg} / \mathrm{L}$ & $<0.015$ & 0.019 & $<0.017$ & 6 \\
BOD & $\mathrm{mg} / \mathrm{L}$ & $<5$ & $<5$ & $<5$ & 2 \\
pH & $\mathrm{SU}$ & 7 & 8.3 & 7.65 & 4 \\
Temperature & $\mathrm{F}$ & 51 & 73 & 62 & 2 \\
Total Suspended & $\mathrm{mg} / \mathrm{L}$ & 6 & 17 & 11.5 & 2 \\
Solids & & & & & 6 \\
PCB & $\mu \mathrm{g} / \mathrm{L}$ & $<0.17$ & $<0.17$ & $<0.17$ & 6 \\
Acetone & $\mu \mathrm{g} / \mathrm{L}$ & $<1000$ & $<1000$ & $<1000$ & 6 \\
Isopropanol & $\mu \mathrm{g} / \mathrm{L}$ & $<1000$ & $<1000$ & $<1000$ & 6 \\
Trichloroethene & $\mu \mathrm{g} / \mathrm{L}$ & 1 & 1 & 1 & 6 \\
\hline & & & & & \\
\hline
\end{tabular}


Table 5.6 1995 Nonradiological Data Summary for Surface Water Location SW5

\begin{tabular}{|c|c|c|c|c|c|}
\hline Analysis & Units & Minimum & Maximum & Average & Count \\
\hline Chloride & $\mathrm{mg} / \mathrm{L}$ & 68.6 & 78.8 & 75.0667 & 9 \\
\hline Hardness as $\mathrm{CaCO} 3$ & $\underset{\mathrm{CaCO} 3}{\mathrm{mg} / \mathrm{L}}$ & 170 & 170 & 170 & 2 \\
\hline Aluminum & $\mathrm{mg} / \mathrm{L}$ & $<0.312$ & 0.321 & $<0.315$ & 9 \\
\hline Cadmium & $\mathrm{mg} / \mathrm{L}$ & $<0.001$ & $<0.001$ & $<0.001$ & 9 \\
\hline Chromium & $\mathrm{mg} / \mathrm{L}$ & $<0.011$ & $<0.011$ & $<0.011$ & 9 \\
\hline Copper & $\mathrm{mg} / \mathrm{L}$ & $<0.012$ & $<0.012$ & $<0.012$ & 9 \\
\hline Iron & $\mathrm{mg} / \mathrm{L}$ & $<0.178$ & 0.216 & $<0.190667$ & 9 \\
\hline Lead & $\mathrm{mg} / \mathrm{L}$ & $<0.003$ & $<0.003$ & $<0.003$ & 12 \\
\hline Nickel & $\mathrm{mg} / \mathrm{L}$ & $<0.05$ & $<0.05$ & $<0.05$ & 9 \\
\hline Phosphorus (P) & $\mathrm{mg} / \mathrm{L}$ & 0.26 & 0.27 & 0.2667 & 9 \\
\hline Zinc & $\mathrm{mg} / \mathrm{L}$ & $<0.015$ & 0.04 & $<0.024$ & 9 \\
\hline BOD & $\mathrm{mg} / \mathrm{L}$ & $<5$ & $<5$ & $<5$ & 3 \\
\hline $\mathrm{pH}$ & SU & 8.8 & 9 & 8.9 & 4 \\
\hline Temperature & $\mathrm{F}$ & 51 & 72 & 61.5 & 2 \\
\hline $\begin{array}{c}\text { Total Suspended } \\
\text { Solids }\end{array}$ & $\mathrm{mg} / \mathrm{L}$ & $<4$ & 7 & $<5.3333$ & 3 \\
\hline PCB & $\mu \mathrm{g} / \mathrm{L}$ & $<0.17$ & $<0.17$ & $<0.17$ & 9 \\
\hline Acetone & $\mu \mathrm{g} / \mathrm{L}$ & $<1000$ & $<1000$ & $<1000$ & 9 \\
\hline Isopropanol & $\mu \mathrm{g} / \mathrm{L}$ & $<1000$ & $<1000$ & $<1000$ & 9 \\
\hline Trichloroethene & $\mu \mathrm{g} / \mathrm{L}$ & 1 & 1 & 1 & 9 \\
\hline
\end{tabular}


Table 5.7 1995 Nonradiological Data Summary for Surface Water Location SW64

\begin{tabular}{lccccc}
\hline \multicolumn{1}{c}{ Analysis } & $\mathrm{Units}$ & Minimum & Maximum & Average & Count \\
\hline Chloride & $\mathrm{mg} / \mathrm{L}$ & 11.6 & 12.6 & 12.1 & 6 \\
Hardness as CaCO3 & $\mathrm{mg} / \mathrm{L} \mathrm{CaCO} 3$ & 36 & 36 & 36 & 2 \\
Aluminum & $\mathrm{mg} / \mathrm{L}$ & $<0.312$ & 1.36 & $<0.836$ & 6 \\
Cadmium & $\mathrm{mg} / \mathrm{L}$ & $<0.001$ & $<0.001$ & $<0.001$ & 6 \\
Chromium & $\mathrm{mg} / \mathrm{L}$ & $<0.011$ & $<0.011$ & $<0.011$ & 6 \\
Copper & $\mathrm{mg} / \mathrm{L}$ & $<0.012$ & $<0.012$ & $<0.012$ & 6 \\
Iron & $\mathrm{mg} / \mathrm{L}$ & 1.52 & 1.86 & 1.69 & 6 \\
Lead & $\mathrm{mg} / \mathrm{L}$ & $<0.003$ & $<0.003$ & $<0.003$ & 8 \\
Nickel & $\mathrm{mg} / \mathrm{L}$ & $<0.05$ & $<0.05$ & $<0.05$ & 6 \\
Phosphorus $(\mathrm{P})$ & $\mathrm{mg} / \mathrm{L}$ & $<0.05$ & 0.11 & $<0.08$ & 6 \\
Zinc & $\mathrm{mg} / \mathrm{L}$ & $<0.015$ & 0.018 & $<0.0165$ & 6 \\
BOD & $\mathrm{mg} / \mathrm{L}$ & $<5$ & $<5$ & $<5$ & 2 \\
pH & $\mathrm{SU}$ & 6.8 & 7.1 & 6.95 & 4 \\
Temperature & $\mathrm{F}$ & 42 & 63 & 52.5 & 2 \\
Total Suspended & $\mathrm{mg} / \mathrm{L}$ & $<4$ & 22 & $<13$ & 2 \\
Solids & & & & & \\
PCB & $\mu \mathrm{g} / \mathrm{L}$ & $<0.17$ & $<0.17$ & $<0.17$ & 6 \\
Acetone & $\mu \mathrm{g} / \mathrm{L}$ & $<1000$ & $<1000$ & $<1000$ & 6 \\
Isopropanol & $\mu \mathrm{g} / \mathrm{L}$ & $<1000$ & $<1000$ & $<1000$ & 6 \\
Trichloroethene & $\mu \mathrm{g} / \mathrm{L}$ & 1 & 1 & 1 & 6 \\
\hline
\end{tabular}




\section{Paducah Site \\ 1995 Annual Environmental Report (KY/EM-176)}

We want to make the Paducah Site Annual Environmental Report easy to read and useful for all members of our audience. The project staff welcome comments, all of which will be considered during the writing of the next report. Please fill out this sheet and mail it to the following address:

V.W. Jones, Environmental Coordinator

761 Veterans Avenue

Kevil, Kentucky 42053

Keep my name on the Paducah Site ASER mailing list.

Add my name to the Paducah Site ASER mailing list.

Remove my name from the Paducah Site ASER mailing list.

Comments:

Name: Organization:

Address: 
Table 5.9 Historical Nonradiological Sediment Sampling Results ( $\mu \mathrm{g} / \mathrm{kg})$ for PCBs

\begin{tabular}{|c|c|c|c|c|c|c|c|c|c|}
\hline \multicolumn{10}{|c|}{ Station } \\
\hline Year & SS1 & SS2 & SS10 & SS11 & SS12 & SS13 & SS14 & SS15 & SS16 \\
\hline 1991 & 100 & 200 & 400 & 600 & 800 & $<100$ & $<100$ & $<100$ & 300 \\
\hline 1992 & 100 & 900 & & & & & & & \\
\hline 1993 & 300 & 20,000 & & & & & & & \\
\hline 1994 & 100 & 1400 & & & & & & & \\
\hline 1995 & $<100$ & $<100$ & & & & & & & \\
\hline \multicolumn{10}{|c|}{ Station } \\
\hline Year & SS17 & SS18 & SS19 & SS20 & SS21 & SS23 & SS24 & SS25 & \\
\hline 1991 & $<100$ & $<100$ & 100 & $<100$ & $<100$ & 400 & $<100$ & 200 & \\
\hline 1992 & & & & $<100$ & $<100$ & & & & \\
\hline 1993 & & & & $<100$ & $<100$ & & & & \\
\hline 1994 & & & & $<100$ & $<100$ & & & & \\
\hline 1995 & & & & $<100$ & $<100$ & & & & \\
\hline
\end{tabular}


Table 5.8 1995 Nonradiological Sediment Data Summary

\begin{tabular}{|c|c|c|c|c|c|c|c|}
\hline Station & Analysis & Result & Units & Station & Analysis & Result & Units \\
\hline SS1 & Barium & 22.4 & $\mathrm{mg} / \mathrm{KG}$ & SS27 & Barium & 20.6 & $\mathrm{mg} / \mathrm{KG}$ \\
\hline SSI & Chromium & 11.2 & $\mathrm{mg} / \mathrm{KG}$ & SS27 & Chromium & 52.9 & $\mathrm{mg} / \mathrm{KG}$ \\
\hline SS1 & Copper & 3.67 & $\mathrm{mg} / \mathrm{KG}$ & SS27 & Copper & 4.78 & $\mathrm{mg} / \mathrm{KG}$ \\
\hline SS1 & Lithium & 2.48 & $\mathrm{mg} / \mathrm{KG}$ & SS27 & Lithium & 2.02 & $\mathrm{mg} / \mathrm{KG}$ \\
\hline SS1 & Manganese & 167 & $\mathrm{mg} / \mathrm{KG}$ & SS27 & Manganese & 86.9 & $\mathrm{mg} / \mathrm{KG}$ \\
\hline SS1 & Potassium & 323 & $\mathrm{mg} / \mathrm{KG}$ & SS27 & Potassium & 273 & $\mathrm{mg} / \mathrm{KG}$ \\
\hline SS1 & Silver & 59.2 & $\mathrm{mg} / \mathrm{KG}$ & SS27 & Silver & 37.8 & $\mathrm{mg} / \mathrm{KG}$ \\
\hline Ss1 & Strontium & 4.16 & $\mathrm{mg} / \mathrm{KG}$ & SS27 & Strontium & 7.16 & $\mathrm{mg} / \mathrm{KG}$ \\
\hline SS1 & Vanadium & 14.8 & $\mathrm{mg} / \mathrm{KG}$ & SS27 & Vanadium & 10 & $\mathrm{mg} / \mathrm{KG}$ \\
\hline \multirow[t]{2}{*}{ SS1 } & Zirconium & 5.84 & $\mathrm{mg} / \mathrm{KG}$ & SS27 & Zinc & 11.7 & $\mathrm{mg} / \mathrm{KG}$ \\
\hline & & & & SS27 & Zirconium & 4.5 & $\mathrm{mg} / \mathrm{KG}$ \\
\hline$\overline{\overline{\text { SS2 }}}$ & $\overline{\text { Barium }}$ & $\overline{39.9}$ & $\overline{\mathrm{mg} / \mathrm{KG}}$ & SS28 & "Barium & 13.8 & $\mathrm{mg} / \mathrm{KG}$ \\
\hline SS2 & Chromium & 42.8 & $\mathrm{mg} / \mathrm{KG}$ & SS28 & Lithium & 0.98 & $\mathrm{mg} / \mathrm{KG}$ \\
\hline SS2 & Copper & 5.38 & $\mathrm{mg} / \mathrm{KG}$ & SS28 & Manganese & 112 & $\mathrm{mg} / \mathrm{KG}$ \\
\hline SS2 & Lead & 28.8 & $\mathrm{mg} / \mathrm{KG}$ & SS28 & Potassium & 213 & $\mathrm{mg} / \mathrm{KG}$ \\
\hline SS2 & Lithium & 3.09 & $\mathrm{mg} / \mathrm{KG}$ & SS28 & Silver & 24.2 & $\mathrm{mg} / \mathrm{KG}$ \\
\hline SS2 & Manganese & 337 & $\mathrm{mg} / \mathrm{KG}$ & SS28 & Strontium & 2.6 & $\mathrm{mg} / \mathrm{KG}$ \\
\hline SS2 & Potassium & 475 & $\mathrm{mg} / \mathrm{KG}$ & SS28 & Vanadium & 5.79 & $\mathrm{mg} / \mathrm{KG}$ \\
\hline SS2 & Silver & 160 & $\mathrm{mg} / \mathrm{KG}$ & SS28 & Zinc & 8.44 & $\mathrm{mg} / \mathrm{KG}$ \\
\hline SS2 & Strontium & 14.2 & $\mathrm{mg} / \mathrm{KG}$ & SS28 & Zirconium & 3.44 & $\mathrm{mg} / \mathrm{KG}$ \\
\hline SS2 & Tin & 180 & $\mathrm{mg} / \mathrm{KG}$ & & & & \\
\hline SS2 & Vanadium & 37.3 & $\mathrm{mg} / \mathrm{KG}$ & "SS21 & Barium & 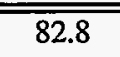 & $\overline{\mathrm{mg} / \mathrm{KG}}$ \\
\hline SS2 & Zinc & 11.8 & $\mathrm{mg} / \mathrm{KG}$ & SS21 & Barium & 82.4 & $\mathrm{mg} / \mathrm{KG}$ \\
\hline \multirow[t]{2}{*}{ SS2 } & Zirconium & 11.2 & $\mathrm{mg} / \mathrm{KG}$ & SS21 & Chromium & 10.7 & $\mathrm{mg} / \mathrm{KG}$ \\
\hline & & & & SS21 & Chromium & 10.8 & $\mathrm{mg} / \mathrm{KG}$ \\
\hline SS20 & Barium & 34.4 & $\overline{\mathrm{mg} / \mathrm{KG}}$ & SS21 & Copper & 6.85 & $\mathrm{mg} / \mathrm{KG}$ \\
\hline SS20 & Chromium & 8.31 & $\mathrm{mg} / \mathrm{KG}$ & SS21 & Copper & 7.2 & $\mathrm{mg} / \mathrm{KG}$ \\
\hline SS20 & Copper & 4.98 & $\mathrm{mg} / \mathrm{KG}$ & SS21 & Lithium & 6.17 & $\mathrm{mg} / \mathrm{KG}$ \\
\hline SS20 & Lithium & 2.54 & $\mathrm{mg} / \mathrm{KG}$ & SS21 & Lithium & 6.85 & $\mathrm{mg} / \mathrm{KG}$ \\
\hline SS20 & Manganese & 301 & $\mathrm{mg} / \mathrm{KG}$ & SS21 & Manganese & 223 & $\mathrm{mg} / \mathrm{KG}$ \\
\hline SS20 & Potassium & 423 & $\mathrm{mg} / \mathrm{KG}$ & SS21 & Manganese & 224 & $\mathrm{mg} / \mathrm{KG}$ \\
\hline SS20 & Silver & 50.2 & $\mathrm{mg} / \mathrm{KG}$ & SS21 & Molybdenum & 5.5 & $\mathrm{mg} / \mathrm{KG}$ \\
\hline SS20 & Strontium & 4.5 & $\mathrm{mg} / \mathrm{KG}$ & SS21 & Potassium & 158 & $\mathrm{mg} / \mathrm{KG}$ \\
\hline SS20 & Tin & 120 & $\mathrm{mg} / \mathrm{KG}$ & SS21 & Potassium & 659 & $\mathrm{mg} / \mathrm{KG}$ \\
\hline SS20 & Vanadium & 14.2 & $\mathrm{mg} / \mathrm{KG}$ & SS21 & Silver & 74.8 & $\mathrm{mg} / \mathrm{KG}$ \\
\hline \multirow[t]{7}{*}{ SS 20} & Zirconium & 4.98 & $\mathrm{mg} / \mathrm{KG}$ & SS21 & Silver & 76.2 & $\mathrm{mg} / \mathrm{KG}$ \\
\hline & & & & SS21 & Strontium & 12.5 & $\mathrm{mg} / \mathrm{KG}$ \\
\hline & & & & SS21 & Tin & 106 & $\mathrm{mg} / \mathrm{KG}$ \\
\hline & & & & SS21 & Vanadium & 20.6 & $\mathrm{mg} / \mathrm{KG}$ \\
\hline & & & & SS21 & Vanadium & 20.8 & $\mathrm{mg} / \mathrm{KG}$ \\
\hline & & & & SS21 & Zirconium & 11.5 & $\mathrm{mg} / \mathrm{KG}$ \\
\hline & & & & SS21 & Zirconium & 12.6 & $\mathrm{mg} / \mathrm{KG}$ \\
\hline
\end{tabular}


Table 5.9 Historical Nonradiological Sediment Sampling Results $(\mu \mathrm{g} / \mathrm{kg})$ for PCBs

\begin{tabular}{|c|c|c|c|c|c|c|c|c|c|}
\hline \multicolumn{10}{|c|}{ Station } \\
\hline Year & SS1 & $\mathrm{SS} 2$ & SS10 & SS11 & SS12 & SS13 & SS14 & SS15 & SS16 \\
\hline 1991 & 100 & 200 & 400 & 600 & 800 & $<100$ & $<100$ & $<100$ & 300 \\
\hline 1992 & 100 & 900 & & & & & & & \\
\hline 1993 & 300 & 20,000 & & & & & & & \\
\hline 1994 & 100 & 1400 & & & & & & & \\
\hline 1995 & $<100$ & $<100$ & & & & & & & \\
\hline \multicolumn{10}{|c|}{ Station } \\
\hline Year & SS17 & SS18 & SS19 & SS20 & SS21 & $\mathrm{SS} 23$ & SS24 & SS25 & \\
\hline 1991 & $<100$ & $<100$ & 100 & $<100$ & $<100$ & 400 & $<100$ & 200 & \\
\hline 1992 & & & & $<100$ & $<100$ & & & & \\
\hline 1993 & & & & $<100$ & $<100$ & & & & \\
\hline 1994 & & & & $<100$ & $<100$ & & & & \\
\hline 1995 & & & & $<100$ & $<100$ & & & & \\
\hline
\end{tabular}

